\title{
GOVERNANCE AND BUREAUCRACY: LEADERSHIP IN NIGERIA'S PUBLIC SERVICE \\ The Case of the Lagos State Civil service (1967-2005)
}


(C) 2006 R.N.I. Oyelaran-Oyeyinka

All rights reserved

Cover design by Jacqueline van Kesteren

Published by Universitaire Pers Maastricht

ISBN 13: 978-90-5278-582-0

ISBN 10: 90-5278-582-1

Printed in the Netherlands by Datawyse Maastricht 


\title{
GOVERNANCE AND BUREAUCRACY: LEADERSHIP IN NIGERIA'S PUBLIC SERVICE The Case of the Lagos State Civil Service (1967-2005)
}

\author{
PROEFSCHRIFT \\ ter verkrijging van de graad van doctor \\ aan de Universiteit Maastricht, \\ op gezag van de Rector Magnificus, Prof. Mr. G.P.M.F. Mols, \\ volgens het besluit van het College van Decanen, \\ in het openbaar te verdedigen op donderdag 26 oktober om 10.00 uur
}

door

Rosamund Naduvi Ibiyemi Oyelaran - Oyeyinka

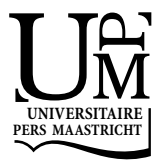




\section{Promotor}

Prof. Dr. Louk de la Rive Box, Rector, Institute of Social Studies, The Hague, and Honorary Professor of International Cooperation, Maastricht University.

\section{Co-promotor}

Prof. Dr. Bamidele Olowu, African Development Bank, Tunisia, and (retired) Professor, Obafemi Awolowo University, Ile-Ife, Nigeria

\section{Beoordelingscommissie}

Prof. Dr. B.J.S. Hoetjes (voorzitter)

Dr. S.D.K. Ellis

Prof. Dr. J.A.M. Maarse

Prof. Dr. F.Y. Phillips

The following institution partially sponsored the $\mathrm{Ph} . \mathrm{D}$. thesis research:

Nederlandse Organisatie voor Internationale Samenwerking in het Hoger Onderwijs (Nuffic) 
"When the righteous are in authority, the people rejoice: but when the wicked beareth rule, the people mourn".

(Proverbs 29: $2 \mathrm{KJV}$ )

"When one rules over men in righteousness, when he rules in the fear of God, he is like the light of morning at sunrise on a cloudless morning, like the brightness after rain that brings the grass from the earth.

(2 Samuel 23:3-4 NIV)

DEDICATION

This book is dedicated to my late parents

Janet Olatunji George (nee Holloway)

And

Mark Tychus Lawson 


\section{Acknowledgement}

To God be the glory, great things He has done. The completion of this $\mathrm{PhD}$ project makes the word of God true in my life that "I can do all things through Christ who strengthens me"Philippians 3:13.

Having a Doctorate Degree is a dream I have nurtured since 1983 after the completion of my Masters degree at York University, Toronto, Canada. I thank God that the dream came to pass in 2006. All those who contributed to the achievement of this life-long vision therefore deserve my recognition and gratitude.

My promotor, Prof. Dr. Louk de la Rive Box (Rector, Institute for Social Studies, The Hague and Honorary Professor of International Cooperation, University of Maastricht) deserves my unending gratitude for the role he played in the conception and completion of this project. He challenged me to believe in myself, and to have the confidence to be critical of received wisdom. I really appreciate this. The exposure to international conferences and workshops, the experience and relationships formed cannot be quantified. Along the line, I became a board member of the African Evaluation Association (AfrEA). He is without a doubt an embodiment of a true Promotor.

Prof. Dr. Dele Olowu, my co-promotor, is indeed God sent. Like Prof. Box will always say, "Dele is the content man", and he indeed lived up to this reputation. His review of every draft of the thesis starts with high commendation and alas, pages of cogent critique but more importantly, positive suggestions that made subsequent higher quality work. I really appreciate his invaluable ideas and suggestions. Inspite of his busy schedule, he gave me an unlimited access. The good Lord will reward this labour of love.

The two of them are indeed a formidable team. Inspite of the fact that they are both Professors of international repute, I am struck by their humility, humour and love for their work. I thank them for the role they both played in securing the NUFFIC scholarship. I bless my God for making me come across them.

I am very grateful to Prof. Dr. B.J.S. Hoetjes, Chairman -Reading Committee. I thank him for his invaluable comments and the speed with which he read the thesis. My thanks also go to other members of the Reading Committee, Dr. S.K.D. Ellis, Prof. Dr. J.A.M. Maarse, and Prof. Dr. F.Y. Phillips for their enthusiasm and readiness in reading the draft of this thesis. I wish to express my heartfelt gratitude to Richard Horne who provided excellent editorial support in the early and final stages of the manuscript.

This research would not have been possible without the explicit support of the past and present Governors of Lagos State. Their Excellencies played an important role in this project. Their consent and collaboration contributed in very significant ways to its credibility and robustness. I am extremely grateful for their time, knowledge and experience that were freely shared to give interviews. May I humbly use this opportunity to mention their names; Brigadier Mobolaji Johnson (rtd.), Commodore G. Ndubuisi Kanu (rtd.), Commodore O. Ebitu Ukiwe (rtd.), Alhaji Lateef Kayode Jakande, Rear Admiral Okhai Mike Akhigbe (rtd.), Colonel Raji Rasaki (rtd.), Sir Michael Agbolade Otedola, Colonel Mohammed Marwa (rtd.), and Asiwaju Ahmed Bola Tinubu.

I am indeed grateful for the assistance of eminent retired knowledgeable civil servants from Lagos State Government, Chief F. A. O. Adeyemi (SSG), Mr A. S. Ajose (HOS), Mrs. S. K. T. Omotesho (PS), (also by proxy, Mr Omotesho), Mrs. O. Adekoya (PS), and Mrs. J. A. Olusoga (PS). Their insights to public administration and policy greatly enhanced my understanding of the public service. Their helpful suggestions and advice contributed to the re- 
alization of this study. I would also like to thank my mentors and colleagues, but whom for the fact, are still in service of the Lagos State Government, I may not be able to mention their names. You made me achieve the near impossible task. They are all from different Ministries and Departments and they gave useful information, filled questionnaires and helped to collect secondary data. I thank them all for their warm reception and hospitality during my fieldwork.

I would like to thank the academic and non-academic staff of Maastricht School of Management for making my stay in the school very comfortable. I must but mention the role of Prof. Dr. Kami Rwegasira and wife Agnes. I thank them so much for their concern and love, and Prof. I really appreciated your taking me through Research Methodology. Prof. \& Mrs. Eno L. Inanga I thank them for their friendship. Profs. Fred Y. Phillips and Steve F. Foster, their comments and ideas during the early stages of this work helped to give it a firm orientation. Ngozi Nwosu is more than a friend; she is a true sister. Ayman Khedr I found a brother in him. They all made my stay at MSM wonderful.

I must at this stage mention some few people at UNU- INTECH (now UNU- MERIT) who gave me some valuable supports. I am grateful to Professor Lynn Mytelka for her support right from the inception of this project. Prof. Rajah Rasiah and his wife, Krishna, I must register my appreciation and the wonderful words of encouragement. Dr Padmashree Gehl Sampath, husband Dirk, and Dr. Catherine Nyaki for their continued friendship over the years, they are more like a family, thank you. Dr Kaushalesh Lal and wife, Usha, they were very nice to me. Thank you K.L for making me understand that statistics could be an interesting subject. I must also thank Geoffrey Gachino for his help in my statistical analysis. Eveline in de Braek, was very friendly, hospitable, and has assisted in many ways. Thank you for helping to format this thesis. I appreciate you, Jacqueline van Kesteren for the cover design of this book. Yvonne de Groot forever being so friendly.

I am hugely indebted to Dr. Lou Ann Barclay, with whom we started to discuss the idea of a doctoral programme while she was in Maastricht. I remember her assistance in trying to identify the right schools where I could do the programme. After admission, she was also there, supplying literature and other reading materials. I am indeed grateful. Some relationships have developed over the years that support Proverbs 18:24b (KJV) "and there is a friend that sticketh closer than a brother." Tetteh and Adeola Mensah, I really appreciate our relationship, they are always there, thank you. Wole and Lanre Adeloye, are indeed true to our friendship. Profs. Dipo and Bisi Aina, have really been a source of inspiration and encouragement. Dr. Yinka Esan is really a sweet sister. Remi Aluko for her support and prayers, thank you. Biola Lamikanra, I thank her for her inspirational words. Mrs Modupe Badaru, ever ready with a word of prayer. I thank Mrs Yemi Akinlawon for her concern and encouragement and Moji Elegbe for her word of grace.

My special gratitude goes to the Christian Community, especially the Redeemed Christian Church of God, Holland Mission. All the conventions and meetings where we all meet and share the word of God, were periods I really cherished. Pastor Bukky Olowu, I thank for her love and prayers, the good Lord will continue to bless her ministry. Pastors Paul and Bola Awede, Ibrahim and Ebun Abarshi, and other Parish Pastors, it has been an honour knowing them all. Now to my local church, Covenant Life Parish, Maastricht, you made my stay in the Netherlands wonderful. I thank the members for their encouragement and support. I deliberately do not mention names. But from little Tobi to Papa Cole, they have all touched my life, and the good Lord will reward them all for their labour of love. My prayer is that Covenant Life Parish will continue to grow from strength to strength in the mighty name of Jesus. To the leadership and all members of Faith City, Redeemed Christian Church Of God, Lagos, Nigeria, my daughter once said of you "this church is just like family". My special gratitude goes to every member of the church, especially Jide and Funke Taiwo for giving me unlimited access to their printing press. 
My love and warmest regards go to my family and my in-laws, all of who constantly monitored the progress of this thesis, especially Mrs. Yetunde Holloway, she has just been wonderful. I feel blessed to have you all as family. Also, my gratitude goes to Yemisi Adedoja, she was there for me at the point of need, the good Lord will bless her and her family abundantly. I thank Boladale Adebowale for her sweet smiles and jokes that helped to keep the momentum of the thesis writing going. To my children, Fola, Banke and Koye, they have been magnificent. Fola has been an inspiration, Banke ever loving and kind, Koye what can I do without his incurable humour, may the good Lord bless them all abundantly. My husband, Prof. Dr. Banji Oyelaran-Oyeyinka, his support helped in bringing this to a happy conclusion. I cannot remember how many times I woke him up in the middle of the night to run an idea through him. His humours and jokes about "Guru of governance and bureaucracy" always help to bring down my apprehension. I thank him for fulfilling the promise he made to my daddy, Mark Tychus- Lawson (late) that he will help me to achieve this wonderful feat. His is indeed a true friend and husband. 


\section{Table of contents}

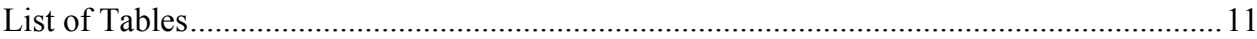

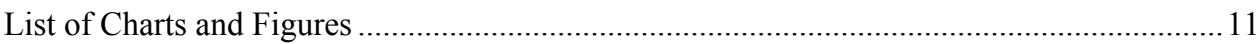

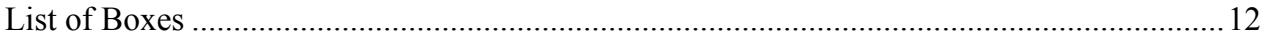

1. Governance and Bureaucracy: Leadership in Nigeria's Public service 13

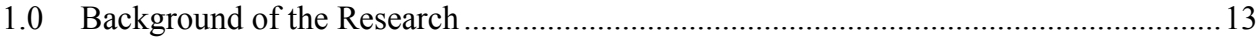

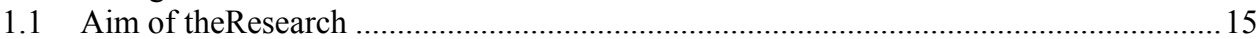

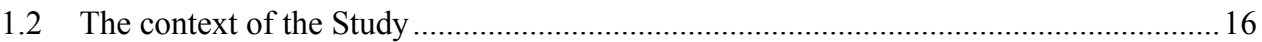

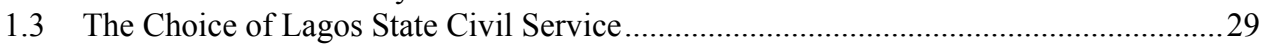

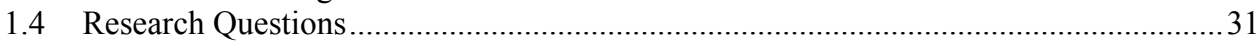

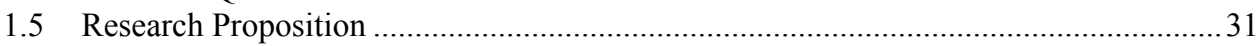

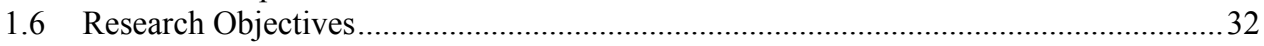

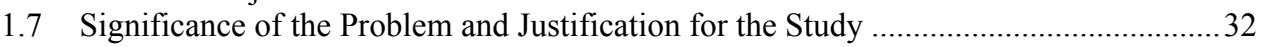

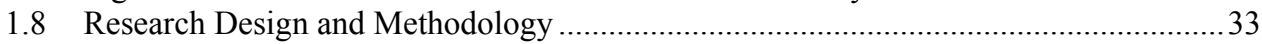

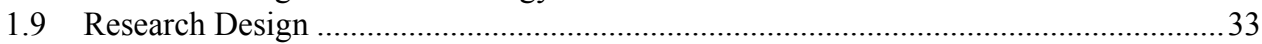

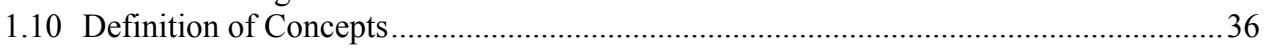

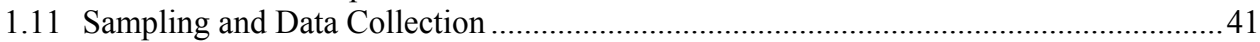

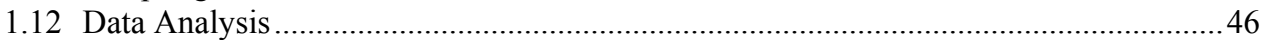

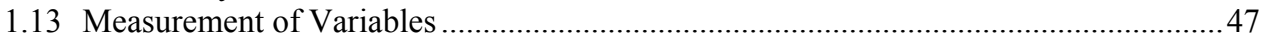

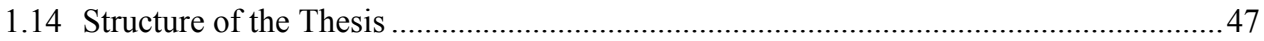

2. Approaches to Public Service Performance in Developing Countries- the Challenge of the New Public Management $\quad 49$

2.1 From Weberian Bureaucracy to New Public management.........................................49

2.2 Is NPM a Solution for African Economies? ................................................................. 54

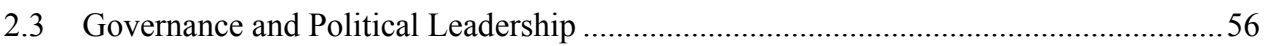

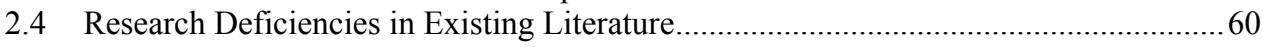

3. Political Leadership and its Influence on Public Policy 63

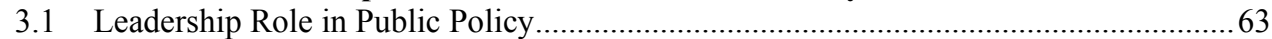

3.2 Institutional Capacity of Government and Public Policy ............................................... 75

3.3 The Patrimonial Disposition of the State and Impact on Public Policy......................... 80

4. Political Leadership and Public Service Performance $\quad 83$

4.1 Leadership Competence on Decision-making and Problem-solving ..............................8 84

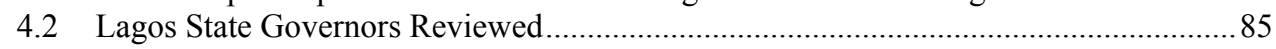

4.3 Perceived Performance Ratings of Lagos State Governors ...................................... 121

5. Institutional Capacity and Public Service Performance 125

5.1 Human Resources Management Policies............................................................. 125

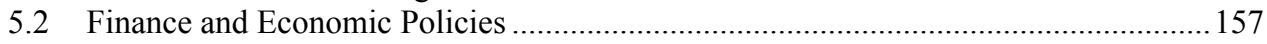

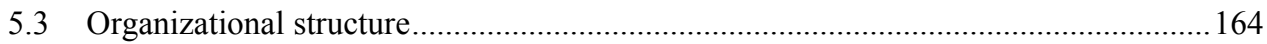

6. Civil Service Reforms and Public Service Performance 169

6.1 The 1971 and 1974 Civil Service Reforms.................................................................. 170 


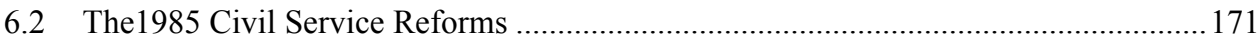

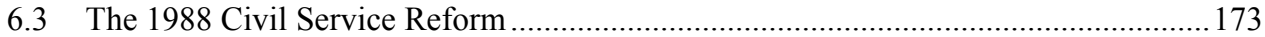

6.4 The Government White Paper of 1997 ............................................................................ 179

7. Conclusions and Recommendation $\quad 183$

7.1 Leadership and Public Service Performance ............................................................. 183

7.2 Institutional Capacity and Public Service Performance .................................................. 186

7.3 Public Policy and Public Service Performance.............................................................. 186

7.4 Civil Service Reforms and Public Service Performance ............................................... 190

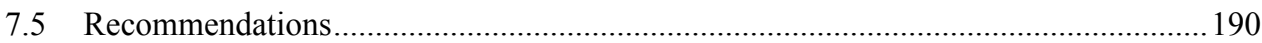

$\begin{array}{ll}\text { References } & 193\end{array}$

\section{Appendices}

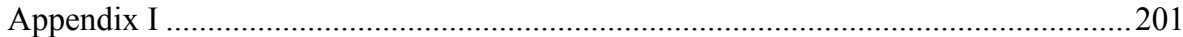

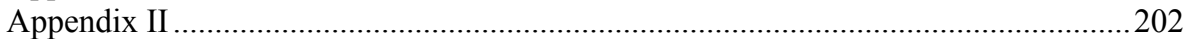

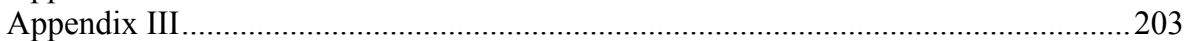

$\begin{array}{lr}\text { Samenvatting } & 215\end{array}$

$\begin{array}{lr}\text { About the Author } & 217\end{array}$ 


\section{List of Tables}

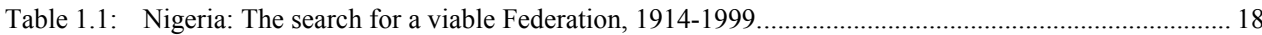

Table 1.2: Distribution of Responsibilities Among Nigerian Governments ..................................................2 24

Table 1.3: The Search for a Viable Revenue Sharing Formula .................................................................2 25

Table 1.4: Lagos versus Kano: Highly Populated States in 1991 and Gross Allocation in 2001 ......................2 27

Table 1.5: Lagos State Government: Recurrent Revenues 1968-2000 (\# Million and Percentages)................. 28

Tabel 1.6: Lagos State: Military and Civilian Governors 1967-2005 ............................................................42

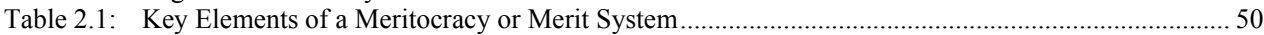

Table 2.2: Bureaucracy and Post-bureaucracy in Government ............................................................... 51

Table 2.3: Peters: Old Public Administration 'Chestnuts' Compared with NPM Doctrines.............................5 53

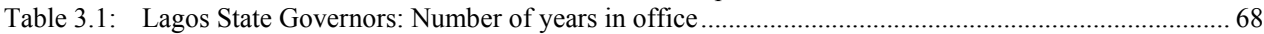

Table 3.2: Lagos State Government: Recurrent and Capital Expenditures 1968, 1978, 1988-2001 ................ 71

Table 3.3: Lagos State: Pressing Social and Physical Infrastructural Needs According to Respondents......... 73

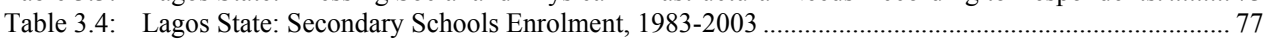

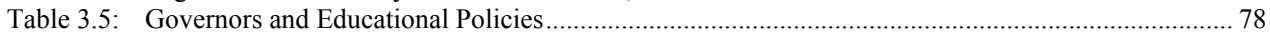

Table 4.1: Nigeria: Road Density in Relationship with the Land Area of States 1978/1979 ......................... 87

Table 4.2: Lagos State: Growth of Secondary Education between 1967-1981...............................................90

Table 4.3: Nigeria: Primary School Enrolment and State Population, 1979/1980. .........................................96

Table 4.4: Lagos State: Growth of Primary School Education, 1967-1981 ................................................. 98

Table 4.5: Views of Political versus Administrative Leaders: Attributed Qualities of Successful Leaders ..... 122

Table 4.6: Perceived Performance Rating of Lagos State Governors ........................................................... 123

Table 5.1 Do military Governors have confidence in civil servants to implement their programmes

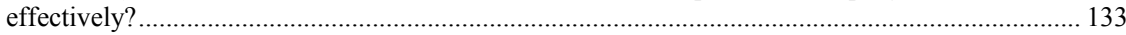

Table 5.2: Do civilian Governors trust the civil servants to implement their programmes effectively? .......... 136

Table 5.3: Lagos State: Levels of Civil Service Management by Gender, 31st December 2002 _................... 138

Table 5.4: Lagos State: Civil Service Staff Strength, December 2002 contrasted with 1982 Civil Service

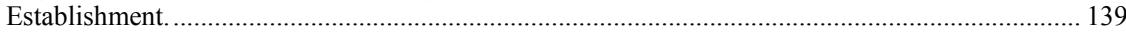

Table 5.5: Lagos State: Ratio of Actual Strength of Public service with Administrative Staff....................... 143

Table 5.6: Lagos State: Factors Affecting the Quality of the Civil service, according to Interviewees............ 144

Table 5.7: Nigeria: Real Wages (Maximum, Minimum \& Annual Percentage change) and inflation rates

(Period Average Percentage change) 1970-1997 .................................................................. 146

Table 5.8: Lagos State: Expenditures on Staff Training (G.L 13-17) as Share of Total Recurrent Expenditure of Government, 1988-2003 (in Naira and percentages) ............................................ 148

Table 5.9: Lagos State: Percentage of Civil Service Staff (G.L 01-12) Trained and Number of Courses

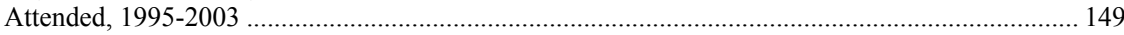

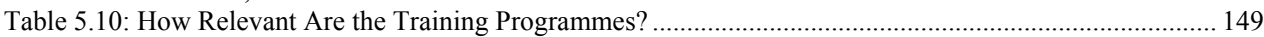

Table 5.11: Lagos State: Numbers of Exits from the Civil Service, 1985-2000 ........................................... 153

Table 5.12: Lagos State: Areas affected by Staff Retrenchment. ............................................................. 157

Table 5.13: Rating of the Federal Government's macroeconomic policy of Structural Adjustment

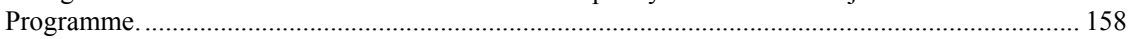

Table 5.14: Lagos State Government Statement of Recurrent Revenue as at 31st December 2000 ................. 162

Table 5.15: Is the Size of Government Excessive? .................................................................................. 166

Table 5.16: Infrastructural Factors Affecting the Quality of Lagos State Civil Service................................. 167

Table 6.1: Nigeria: Indigenous Civil service Reforms, 1934-1994 ............................................................ 170

Table 6.2: Lagos State: List of Heads of Service and Secretaries to the State Government, 1968-2005 ......... 176

\section{List of Charts and Figures}

Chart 1.1: Malaysia and Nigeria: GDP Per Capita in US Dollars (1970-2004) ................................................20

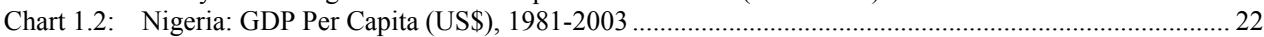

Chart 1.3: Nigeria: Population, Secondary \& Primary School Enrolment and Life Expectancy, 1994-1998..... 23

Chart 3.1: Lagos State Government: Capital Expenditure- Sectoral Allocation, 1985-2001 …....................... 72

Chart 3.2: Lagos State: Percentage of Total State Appropriation for Education, 1983-2003 ............................ 76

Chart 5.1: Lagos State: Staff Strength of the Public Service, 1982-2002 _.................................................. 137

Chart 5.2: $\quad$ Lagos State: Recruitment in Civil Service for staff between Grade levels 08-17, 1985-2000........ 140

Chart 5.3: Lagos State: Intercadre Transfer decided by the Civil Service Commission, 2000 ....................... 143 
Chart 5.3: Lagos State: Intercadre Transfer decided by the Civil Service Commission, 2000

Chart 5.4: Lagos State: Number of Exits from the Civil Service by Regimes between 1985-2000

Chart 5.5: Lagos State Government: Percentage of Administration Cost to Total Expenditure of Government, 1985-2003

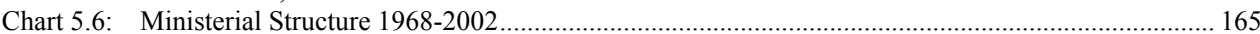

Figure 1.1: Research Model of Organizational Performance: Lagos State Civil Service .................................. 35

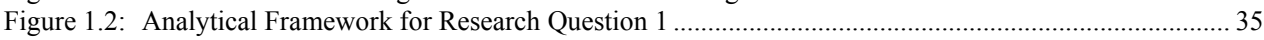

Figure 1.3: Analytical Framework for Research Question 2 ............................................................... 36

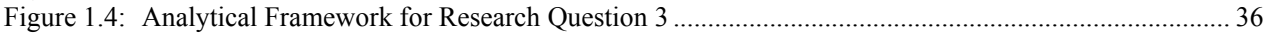

Figure 2.1: Combination of Regime Types and Leadership Styles .......................................................... 58

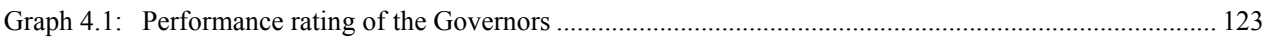

\section{List of Boxes}

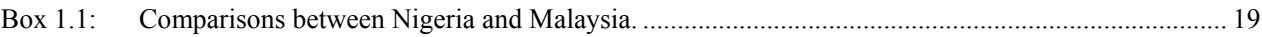

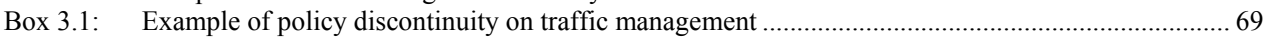

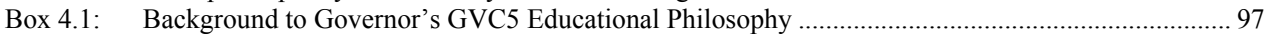

Box 4.2: DSII thought on the environmental sanitation policy of GVC12 .......................................... 118

Box 5.1: Governor GVM8's views on his relationship with the administrative leadership........................ 131

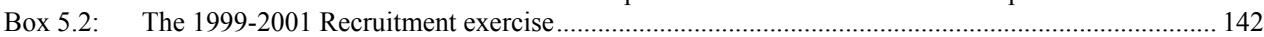

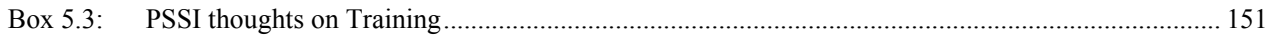

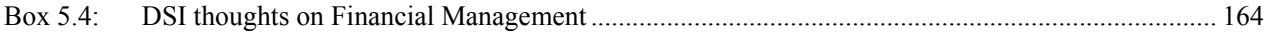




\section{Governance and Bureaucracy: Leadership in Nigeria's Public service}

\subsection{Background of the research}

Institutions ${ }^{1}$, according to North (1990), are central to the development process. The public service, an institution at the heart of governmental policy formulation and implementation, influences in non-trivial ways, the success or failure of governments. The public service in most developing countries is central to the economic and socio-political development of such countries (World Bank, 1997) because of the relative weakness of the private sector. However, there is increasing evidence pointing to the deterioration of the public service's performance in Africa. International organizations, financial institutions and researchers believe that poor economic performance, high levels of poverty and corruption in Africa can be linked to poorly designed macroeconomic policies as well as weak institutional structures, political misrule, bad governance and absence of liberal democracy (Mutahaba 1989; Therkilsen 2001). The observed shortcomings of the public service have also been linked to inadequate financial, infrastructure and human resources, particularly the latter.

Following their independence from colonial rule, many African states have attempted public service reforms in order to improve their socio-political and economic performances. Studies show that some newly independent states were able to provide quality services to the populace immediately after the post-independent years, particularly in the period from 1960$1970^{2}$. During the 1950s and 1960s, the Nigerian Civil Service was regarded as one of the best in the Commonwealth, and up until the mid 1980s, the Lagos State Civil Service that emerged from the Federal and Western Region Civil Service was regarded as one of the most efficient in Nigeria (Olowu 1990). However, many African states did not extend the concerted efforts made to gain independence to socio-economic development, but continued to maintain the neo-colonial dependent economies with its inherent limitations (Adamolekun, 1988). These states were therefore ill equipped to deal with the multiple crises that faced the continent following the global oil shocks of the 1970s and the attendant economic recession (Mutahaba, 1989). These factors affected a pivotal element of these countries development - the public service.

At the prodding of World Bank and other donor agencies, African governments in the 1980s embarked on extensive reforms to improve their public service. According to UNRISD (2001), the following five questions constitute the central plank of public sector reforms in Africa:

- Has the size of government employment changed?

- Have government functions become more focused on "core" activities?

- Have real wage levels changed?

- How appropriate are New Public Management (NPM)-inspired accountability measures?

\footnotetext{
${ }^{1}$ Accoding to (North, 1990:1), "Institutions are the humanly devised constraints that structure human interaction".

${ }^{2}$ For example in Nigeria, despite the political upheaval that followed immediately after Nigeria's independence in 1960, that eventually led to the Nigeria civil war (1967-1970), the civil service was resilient enough to hold the country together while the political actors were engaged in continuous acrimony. It is to the credit of the civil service that the country fought a 3-year war without resolving to external borrowing to finance the war. Accounts of this period can also be read in Adebayo (2001).
} 
- Who supports and who opposes reforms?

These questions reflect the guiding principles on public service reforms as "endorsed" by the Special Programme of Assistance for Africa (SPA) as a tool for better donor coordination. Improving public service performance was regarded as a key component to the Structural Adjustment Programme (SAP) promoted and enforced by the World Bank, International Monetary Fund and other donor organizations. Accordingly, these reforms demand that governments should:

- Downsize the civil service to make it more affordable and to bring it in line with a new, scaled-down role for government in economic activities;

- Provide civil servants with appropriate incentives, skills, and motivation; and

- Enhance management and accountability (Lienert, 1998).

Furthermore, reforms assumed renewed urgency in response to globalization of the financial and skills markets, driven largely by the development of information and communication technologies. These technical advances have induced developed and less developed countries alike to initiate public service reform in order to raise the quality of the conduct of public affairs and to enable countries to compete effectively in an era of unprecedented global change.

Public service reform is a complex process that may involve profound changes in the policies, strategies, and programmes of governments to make them more responsive to the demands of the people. It was evident that the Nigerian Public Service like many others in Africa needed radical changes. The government needed to respond to widespread poverty and income inequalities by improving its services delivery to the citizenry, and to promote a system of transparency and accountability. Observations show, however, that the reform measures adopted by many countries in Africa failed to achieve their objectives. The failures have been credited to inaccurate problem evaluation.

According to Olowu and Adamolekun (1999) donors, multilateral agencies and governments consistently make wrong diagnoses and prognoses of civil service problems in Africa. Some decisions are based on inadequate information. The 'ideological lens' through which donors see the problems of development may also have given rise to the tendency to apply the same solution to Africa's problems irrespective of differing histories. Subsequently issue analysis is largely supply-driven rather than being demand-driven. For instance with respect to capacity building, Land, (2002: 2) posits, "Capacity development is an endogenous process which cannot be imposed, or replaced by outside interventions. It requires political leadership and commitment to change, and is stimulated by a demand for knowledge. It is a long term process." Donor agencies usually have a period by which to report to their sponsors and this puts them under constraint to get quick results. Ultimately, they tend to by-pass existing structures instead of working through them, based on the assumption that "knowledge resides mainly in the donor countries and needs to be transferred. But there is knowledge everywhere and true partnership implies equitable sharing and utilization" (Land, 2002: 2).

Much of the research on the African Civil Service has focused on getting the "policies right" in the shortest possible time without a clear focus on reforming the institutions. Reform agents lack understanding of the historical forces that shaped the extant institutions as well as the observed pattern of behaviour of civil service actors. It is therefore not surprising that the prognosis failed to give the desired results. For example, some earlier reforms adopted the human resources policies that emphasized "cutback strategies" as the most relevant to improvement in the performance of the public service; and to correct fiscal and macro-economic imbalance (Olowu, 2001). From the available literature, we advance the proposition that the adapted human resources management policies on which the reforms are based have had negative impact on the civil service performance, because they are not based on the actual historical and contextual realities in each country. This study attempts to approach the subject by 
focusing on one national case study, Nigeria. Since Nigeria is Africa's largest country comprising 36 states, the research centres on the experience of one state, Lagos.

In Nigeria the Federal Government embarked on several home-grown civil service reforms after independence with the Morgan Commission (1963), Eldwood Commission (1966), Adedo Commission (1971), Udoji Commission (1972), Dotun Philips reforms (1985), Decree No. 43 (1988) and the Ayida Review Panel (1994). At the request of international financial institutions, in particular the International Monetary Fund (IMF) in 1985/86, the Structural Adjustment Programme was adopted and has had a great impact on the structure and performance of the Nigerian Public Service. It should be noted that the home-grown reforms and the one adopted at the behest of the international organizations are not the same in approach, motivation and constitution.

The Federal Government of Nigeria operates in a unitary manner due to a variety of factors: several years of military rule, the dominance of oil in the national economy and public revenue system. Inevitably all the state governments in the federation participate in all the various reforms irrespective of whether the states have the capacity and the capability to execute them. The dearth of knowledge about the critical concerns of governance in the states is due to lack of systematic research on the issues of governance and the bureaucratic set-up of the public service especially at the state level. Researchers have not given sufficient attention to how the public service affects the political and socio-economic environment of the country. This is one of the issues this research examines.

\subsection{Aim of the Research}

First, the broad aim of this research is to study how the Nigerian Public Service has evolved from the 1960s after independence, using Lagos State Civil Service as a case study. This research acknowledges a major work titled "Governance, Society and Economy of Lagos State between 1967-1983" carried out by (Olowu, 1990). The focus of his work was to examine the role played by state governments in the development process; the latter defined to mean "socio-economic improvement and national integration". This research will therefore build on this work as it affects the civil service, and examine the changes that have taken place twenty years afterwards in Lagos State.

Second, the study systematically analyzes the role of political leadership in the governance of Lagos State. From 1967-79, the state had a military government. Thereafter, 19791983 represents another political landmark in Nigeria as the country returned to democracy. The military returned to power in 1984 and ruled till 1999, except for a brief period of civilian government in 1993-1995. This study proposes that the role of the political leaders, be they military or civilian, is very important in the performance of government and the public service. In other words, the effectiveness of government is profoundly affected by leadership qualities. The influence of the leaders, especially executive Governors ("military/authoritarian" or "civilian/democratic") on the formulation and implementation of public policies affects the performance of the public service. In addition, the quality of the bureaucracy and the ways in which the political and bureaucratic institutions relate to one another is a determinant of performance.

This study therefore conceptualizes the public service in terms of relationships. We view it as a system with interacting components such as the institutional environment (human, physical and financial) and the key actors and its leadership, and how these translate into the policy making process. In sum, we take the position that the public service is a system with (i) actors, (ii) an institutional environment, (iii) evolving within a historical context that shapes it, and (iv) interacting with each other at the state and the federal levels. With the state embedded in a federal structure, it is important to account for these influences. 
Third, the economic recession of the 1980s and the introduction of "Austerity Measures" by the Federal Government have inadvertently affected the state development processes by impacting public services delivery. We propose that the subsequent introduction of a Structural Adjustment Programme (SAP) and the related reform policies equally affected the institutional capacity of the Nigerian Public Service and the Lagos State Civil Service.

Further, most home-grown and adopted public service reforms have not been contextualised in the light of specific historical, socio-cultural and political issues. There has been a tendency to be more prescriptive, based on a 'one-size fits all approach' rather than analysis of the actual political economy and institutional issues of each state in the country. Much has been written about the national level, when in fact the reality of political action is complicated in a country by the nature of intergovernmental relations. State governments are important actors because they mediate relationships between the Federal Government and also impact on their societies, and their local and community organizations, in their own right. This is one of the issues this research also examines.

\subsection{The Context of the Study: Nigeria's Politics and Economy}

With a population of over 120 million, Nigeria is the largest nation in Africa. This population base, combined with the country's enormous natural resources, has led to it being referred to as the 'giant of Africa'. Independent since 1960, the region was under British rule from 18611960 and became known as Nigeria in 1914 with the establishment of a unified governmental structure. This marked the beginning of the Nigerian Civil Service (Olowu et al., 1997:3). The country inherited the Westminster model of government. This colonial civil service model was characterized by three features, namely, the dominance of the top echelon by the British bureaucrats; the concentration of executive, judicial and legislative powers in the hands of the colonial appointees (Adamolekun, 1986:33); and the indirect rule of governance (that relied mainly on traditional rulers). The civil service during this period was kept small because the Colonial Government undertook no comprehensive socio-economic planning and the maintenance of law and order was delegated to the traditional rulers.

At the time of independence in 1960, Nigeria was divided into three regions, namely, Southern, Northern and Eastern, with the Federal Government at the center having its capital in Lagos. This period was characterized by the Nigerianisation of the civil service, (although the pace was different at the various governmental levels) and the desire of political leaders to bring development to the newly independent state. These factors led to the growth of the public service after independence. Subsequently, the Federal Government became the largest employer of formal labour. Since that period, the Nigerian Public Service has been highly influenced by the socio-economic and political development of the country. In the next section we give an account of the evolution of the political economy of Nigeria. We then put into historical context the politics of revenue allocation and the structure of the financial resources of Lagos State as it helps us to appreciate and understand the challenges of state-level government in the discharge of its social responsibilities. 


\section{The Evolution of Nigeria's Political Economy ${ }^{3}$}

When the country gained its independence on the $1^{\text {st }}$ of October 1960 , it had a multi-party democracy with a federal constitution, an independent judiciary and an efficient public service noted for its resilience. A series of actions in the political realm, however, led to the disruption of the existing system. Political crisis erupted within the regionally based political parties. The subsequent intra-party crisis in Western region, exacerbated by the dispute over the $1962 / 63$ census and the subsequent outbreak of violence in the Western region and some part of the Northern region, led to the military intervention of 1966, and the beginning of military rule in Nigeria (World Bank, 2002).

Nigeria, even before independence, operated as a federal state. Federalism according to Stepan (1999) is a system where authority is divided between the center and other sub-units in a federal political order. There is therefore more than one territorial level of authority to which the populace have political obligations. According to the constitution of a federal state each territorial sub-unit has its area of jurisdiction whereby it can act autonomously (Riker, 1964: 11). The units can therefore act independently of each other in certain areas that have been guaranteed in the constitution of the country and which cannot be altered unilaterally. The political history of some countries reveals that federalism emerges when people of sociocultural and ethnic diversities find themselves in the same political order, and therefore seeks for ways to accommodate their differences. Power-sharing between the center and other subunits varies from country to country.

Proponents of federalism opine that it is a way of promoting non-domination, immunity and enhanced opportunity (Elazar 1987a). In a federal arrangement therefore, the sub-units may secure immunity and non-domination from the central authorities. The constitution allocation of powers help to establish such protection at the same time the interrelationship help the sub units to have influence on the decision making at the center. The rights of the minorities in the sub-units are thus protected (Goodin 1996).

The Nigerian federal system was comparatively weak, even though at the beginning it had both the role of common services provider and unity maker holding the country's three regions together. The regions however were relatively autonomous and each had control over its revenues ( $50 \%$ retention by regions of origin, $30 \%$ to distributable pool account shared by all the regions and $20 \%$ to the Federal Government). Each region was also a political entity with a strong ethnic base. Over time, unpredictable forces of history and the built-in complexities of ethnicity and cultural diversity shaped Nigeria's federalism.

In 1967, the Eastern Region attempted to secede and create an independent State of Biafra after what analysts described as the wanton killings of the Easterners in the Northern Region. This led to the Nigerian civil war that lasted for 30 months. The military government response to the situation was the creation of twelve states out of the three regions, and this helped to break-up the regional power bases and weaken their political influence. According to the World Bank, (2002: 6-7), "The military believed that by creating a larger number of relatively weak states under a strong central government it could overcome the instability of the past. Put simply, the military sought to unilaterally redefine the shape of Nigerian federalism into one consistent with its own hierarchical structure and vision". Since the civil war in 1967 and the ascendancy of oil in the national economy from 1970s, the extent of state autonomy has been low especially during military regimes.

\footnotetext{
${ }^{3}$ For more information on the political and economic relationship between the Federal and the State governments see articles by A.B. Akinyemi, P.D. Cole, W. Ofonagoro (eds.) Reading on Federalism (Lagos, Nigerian Institute of International Affairs, 1979) and Quarterly Journal of Administration 16,2 (January 1980) Special Issue on "Intergovernmental Relations in Nigeria". You can also check B. Smith, "Federal-State Relations in Nigeria” in African Affairs 80, 320 (July 1981).
} 
Therefore, from the late 1960s, the Nigerian Federal Government has always played a central role in the development process, irrespective of the significant involvement of the state and local governments in the process through the provision of public services and by the economic contributions of the citizenry. Before 1979, all revenues from oil and other income like excise, import and export duties, and agricultural commodities were deposited into the federated account, and the revenues divided as follows: federal government (75\%), state governments $(22 \%)$, and local governments $(3 \%)$. The earlier derivation formula whereby half of the revenues would return to the regions where the commodities were derived was discontinued during the civil war period. Therefore, losses of financial autonomy, the subsequent asymmetric power and the economic relationships between the now $36^{4}$ state governments in Nigeria have their root in the actions taken and perpetuated by the military (World Bank, 2002).

The state and local governments are therefore heavily dependent on the federal government for statutory budgetary allocations and their autonomy. Table1.1 shows that state autonomy is usually medium during periods of democratic rule but since 1999, it has been medium but rising.

Table 1.1: Nigeria: The search for a viable Federation, 1914-1999.

\begin{tabular}{|c|c|c|c|}
\hline Year & $\begin{array}{c}\text { Number of Regions } \\
\text { or States }\end{array}$ & $\begin{array}{c}\text { Extent of Regional } \\
\text { or State Autonomy }\end{array}$ & Regime Type \\
\hline 1914 & 2 & Very High & Colonial \\
\hline 1954 & 3 & Very High & Colonial \\
1963 & 4 & High & Democratic \\
\hline 1967 & 12 & Low & Military \\
1976 & 19 & Low & Military \\
\hline 1979 & 19 & Medium & Democratic \\
\hline 1991 & 31 & Low & Military \\
1996 & 36 & Very Low & Military \\
\hline 1999 & 36 & Medium \& Rising & Democratic \\
\hline
\end{tabular}

Source: Nigeria: State and Local Governance in Nigeria. The World Bank, AFTPR, Africa Region, July 23, 2002

The attendant outcome of low state autonomy during military regimes is that many of the states are economically weak and have to depend on federal allocations for the implementation of their programmes. Moreover, it is the federal government that put people into political positions at the state levels. This has engendered autocracy and corruption ${ }^{5}$. Resources are not equitably shared; allocation and infrastructural developments are sometimes based on solidarity and ethnic affiliations. The ability of state governors to obtain what is their legitimate budgetary allocation by the various states also depends on the "connection" or relationship of the state to the federal government. Inconsistencies in budgetary allocation always affect the pattern of capital expenditure of these states. Over time, an imbalance between the monetary allocation to the state and the local governments and public service delivery mandates begin to occur (Olowu, 1990). Furthermore, the creation of many of these states (usually during military regimes) was based more on political consideration and less on economic viability, and some of them are not economically viable up till now (World Bank, 2002). Capacity for governance and development therefore varies across the states.

\footnotetext{
${ }^{4}$ After the initial division of the country into twelve, it was later divided into 20 and finally 36 States, with the Federal capital at Abuja.

${ }^{5}$ Throughout this thesis I have given an account of how Federal Military Government engendered autocracy and corruption through various acts of governance. One of such ways is the unilateral and non consultative appointment of governors and state government official.
} 
Since independence Nigeria operated two types of governments, military and civilian. The political history ${ }^{6}$ of many developing nations like Nigeria, and that of other Asian countries like Malaysia and Indonesia, has not been a smooth evolutionary transition of markets and progressive democratization. These countries have, with different governance systems (monarchy, military, aristocracy and so on), operated diverse economic structures. In spite of the relative political instability experienced by these countries some have faired relatively well in their economic growth - a good indicator of the performance of government of these countries. Some close observers have linked successful cases of economic performance to much better equipped public administration systems than others (World Bank 1989).

Researchers also note that political leaders with development-oriented policies contribute to the growth of the institutional capacity of government and are able to develop good public policies for the improvement of the quality of life of their citizenry. These leaders are able to move their countries out from a "lower level of development to a higher level with reduced poverty, marked by significant improvements in respect of the basic needs of education, health, food, and housing" (Adamolekun, 2002:10). The qualities of the political leaders always have a bearing on the formulation and implementation of policies and this ultimately affects the civil service performance. For example, Box 1.1 shows the comparison between the governments of Nigeria and Malaysia, and Chart 1.1 shows the divergent evolution of GDP Per Capita in US Dollars (1970-2004) between Malaysia and Nigeria.

Box 1.1: Comparisons between Nigeria and Malaysia.

Nigeria and Malaysia share a similar political history; the two countries got their independence from the British in 1960 and 1957 respectively. These nations are also multi cultural societies with many ethnic groups. The two are on the same latitude on the Equator, although Nigeria is in West Africa, Malaysia is in Southern Eastern part of Asia, they have similar climates and vegetation. They are also oil-producing countries with Nigeria being the $4^{\text {th }}$ largest producer in the World and Malaysia being a net exporter. In the $1960 \mathrm{~s}$ both countries were at the same developmental level with the Malaysian economy dependent on tin and rubber and Nigeria on cocoa, groundnut and rubber. The two countries export palm oil; the produce was first extracted from Western and Eastern Africa, but was later exported to Malaysia. However, by 1966 and 1977 respectively, Malaysia overtook Nigeria as the world's leading exporter and producer of palm oil, and the country now accounts for about half the world's production of palm oil. In addition, Malaysia has become a major exporter of electronic goods and in the process raised the standard of living of its people significantly. Malaysia's GDP per capita in 1970 and 2004 were US\$319 and US\$ 4,731 respectively; while that of Nigeria for the same years were US\$ 199 and US\$ 594. Malaysia boasts in some areas a first-world infrastructure developed through the prudent use of its natural resources while Nigeria was mired in developmental crises. Much of the credit for the rapid economic progress of Malaysia has been attributed to good leadership and the vision of its former Prime Minister Dr Mahathir Muhammed who was the country's leader for 22 years.

Source: Gopal, J. (2001). The Development of Malaysia's Palm Oil Refining Industry: Obstacles, Policy and Performance. PhD Thesis submitted to Imperial College, London

\footnotetext{
${ }^{6}$ The "Asian Tigers" (South Korea, Hong Kong, Taiwan, and Singapore) had also experienced rapid economic development in spite of their different political history that was not entrenched in democracy.
} 
Chart 1.1: Malaysia and Nigeria: GDP Per Capita in US Dollars (1970-2004)

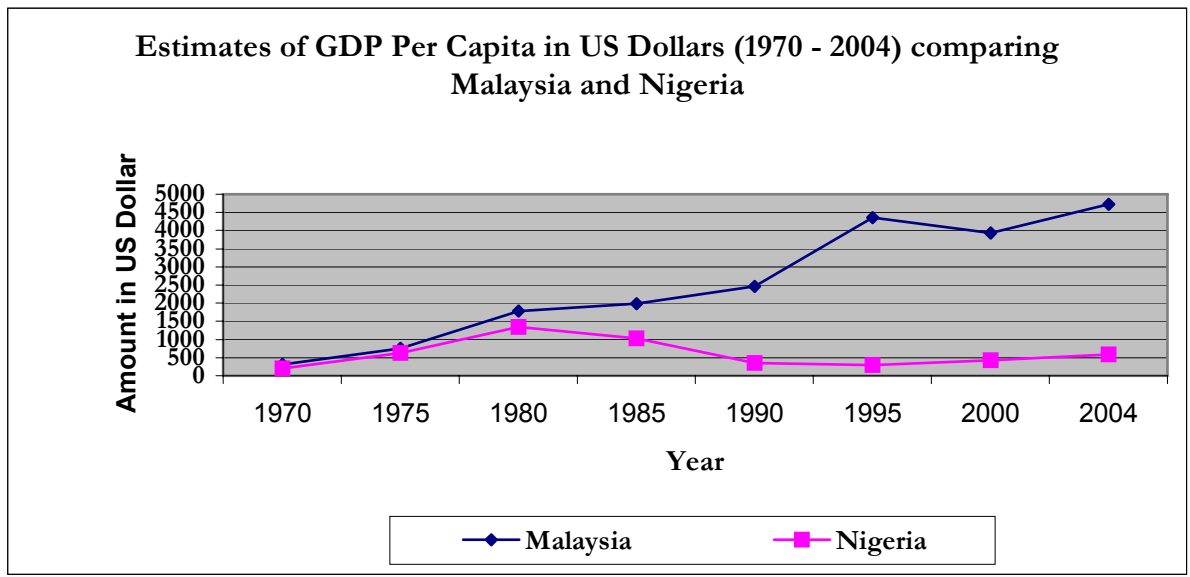

Sources: http://www.imf.org/external/pubs/ft/weo/2006/01/data/dbcoutm.cfm http://unstats.un.org/unsd/snaama/resultsGDP.asp http://www.historicalstatistics.org/

\section{Socio economic environment in Nigeria}

Many countries in sub-Saharan Africa, including Nigeria, were affected by serious economic crises from the late 1970s. In view of the central role the Federal Government plays in the country's economy, whatever affects it inevitably spills over to the states because of their close ties. The politics and policies of the central government propelled the Nigerian economy from 1960 to the mid 1980s (Ajakaiye et al., 1999) and beyond. The economic crises of Nigeria, which became evident in the late 1970s with the end of the oil boom, resulted in persistent balance of payment deficit. Nigeria is one of the leading exporters of oil, with half of its GDP coming from oil which makes up of $90 \%$ of government's revenue. Subsequently Nigeria resorted to borrowing and the government was forced to enter into negotiation with the IMF for a US\$2.4 billion facility loan. The condition under which the International Monetary Fund granted the loan was the adoption of the Structural Adjustment Programme, which promised a better performing public sector. However, rather than the promised turn around of the economy, the economic crisis became more severe after the introduction of the Structural Adjustment Programme ${ }^{7}$.

One of the conditionalities of SAP was the removal of the petroleum subsidy. In addition, the Structural Adjustment Programme emphasized devaluation of the Naira. The initial aim of the loans was to expand domestic productive capacity and production. However, Nigeria like other developing countries, suffered problems of poor project execution and most of the projects ended up as white elephants. Furthermore, industrialized countries also create market inaccessibility for these countries. In the period between 1970s and 1980s, many subSaharan African (SSA) countries experienced stagnation and even decline in the exportation of their commodities, as well as semi-processed and manufactured goods. It was obvious that there was a serious trade imbalance between the SSA countries and the rest of the world.

\footnotetext{
${ }^{7}$ While the SAP triggered widespread factories closing and unemployment, the protracted instability in the Nigerian economy may be traced to the reliance on the oil. The fluctuation in the oil price and the instability in the oil sector adversely affect the structure of the Federal Government expenditure.
} 
At the same time, excessive debt servicing obligations undermined domestic production activities. Olisadebe (1995) noted that "In 1994, scheduled debt service payments amounted to $\$ 4,008$ million excluding arrears and absorbed $42.0 \%$ of exports. If stock of arrears were added, debt service payments due in 1994 would rise to $\$ 9,873$ million or $104 \%$ of export of goods and non-factor services. Therefore, between the period of 1991 and 1994 the level of debt service payments escalated so that more than half of total government expenditure went to servicing debt, leaving limited resources for the economic and social sectors, a development which frustrates growth".

Over a decade after this, the Finance Minister of the Federal Government of Nigeria, Mrs. Ngozi Okonjo-Iweala, in her speech to the Mayor of London's conference on March 5th 2005 noted, "Africa is carrying a millstone around its neck, the millstone of debt. African countries owe a total of 250 billion dollars and they spend about 15 billion dollars in debt service each year. My country Nigeria alone owes 34 billion in external debt. 85 per cent of this or 28 billion dollars is owed to that group of creditors called the Paris club made up of many countries like UK, Japan and the US. Much of this debt was incurred during a time of high interest rates in the early 80 s when the country could not and did not service the debt. It ballooned through penalties and capitalisation of interest, to where we are today - $\$ 34$ billion. It is this millstone that is making it so hard for African Governments including my own to divert money to vital services like health and education, to recover, and to make reforms work well and to persuade our people that sacrifices are worth making 8 ."

Chart 1.2 illustrates the level and severity of the economic crisis the country has faced since the introduction of the Structural Adjustment Programme in 1986. This was a situation caused by both internal and external factors, however, details of the cause and response to the economic crisis is not a subject for this study. At issue is the promotion of an economic reform programme by national policy makers and the international financial institutions that led to widespread de-industrialization. In short, poor governance, poorly designed economic programmes and badly implemented projects in an increasingly hostile international environment adversely affected the economic development of the country. Chart 1.2 shows the Gross Domestic Product (GDP) per capita of Nigeria from (1980-2003) before, during and after the introduction of the Structural Adjustment Programme.

\footnotetext{
${ }^{8}$ In view of the huge burden of debt servicing and the lack of growth of the economy, the Federal Government has called for the rescheduling and cancellations of some of these loans. Subsequently since late 2005, the debt forgiveness programme has resulted in significant reduction of Nigeria's debt. In April $21^{\text {st }} 2006$ Nigeria became the first African nation to pay off its multi- billion dollar Paris Club debt.
} 
Chart 1.2: Nigeria: GDP Per Capita (US\$), 1981-2003

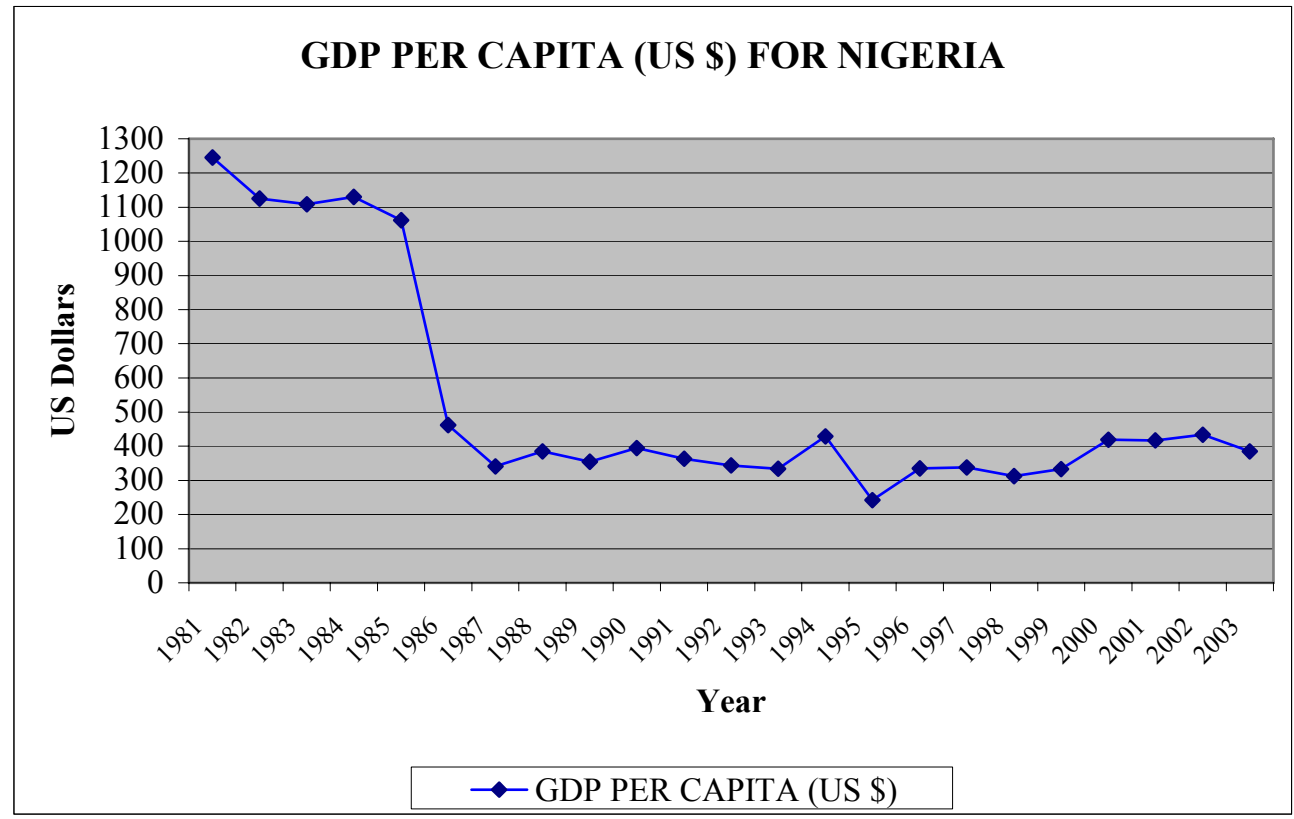

Source: Central Bank of Nigeria- Nigeria: Major Economic, financial and Banking Indicators 1980-2003 (MEF \& BI 2004), Nigeria

Note: Exchange rate between US\$ and Nigerian Naira between 1995-2003. The two currencies were almost at par in the late 1970s. In $1985=\$ 1.2$

1995 - 1US\$: \# 21.78

1996 - 1US\$: 83.50

1997 - 1US\$: 77.00

1998 - 1US\$: 75.00

1999 - 1US\$: 88.85

2000 - 1US\$: 99.40

2001 - 1US\$: 109.50

2002 - 1US\$: 114.48

2003 - 1US\$: 123.75

2004 - 1US\$: 137.00

2005 - 1US\$: 129.50

Source: http://www.oanda.com/convert/classic

The chart depicts Nigerians' poor standard of living and an equally poor economic performance. The chart shows that before the introduction of SAP in 1986, the dollar-valued GNP per capita of the country in 1985 was $948.62^{9}$ or $\$ 1061.33$, but by 1986 there was a sharp drop to 934.44 or $\$ 462.46$. The Naira was devalued by over $100 \%$ in 1986 . This means that economic crisis became more severe after the introduction of the Structural Adjustment Programme and about twenty years after this the GNP per capita of the country has still not risen to pre-SAP period. The study attempts to reflect on how the economic performance of the country affected the performance of the civil service.

\footnotetext{
${ }^{9}$ This figure shows that in 1985 before the adoption of the Structural Adjustment Programme, the Nigerian Naira was stronger than the US\$
} 
In spite of the country's human and natural resources, its potential for economic growth and development has not been fulfilled. According to the Report of the Central Bank of Nigeria between 1991-2001, the economic performance of the country was better in 1991 with a growth rate of gross domestic product (GDP) of $4.8 \%$ compared with $3.8 \%$ in 2000 . Over the period of ten years, 1991-2001, the economy of the country has been unstable. The international oil price for Bonny Light (in US\$ per barrel) fluctuated, from 20.14 US\$ in 1991 to 16.17 US\$ in 1994, 12.9 US\$ in 1998 to 28.6 US\$ in 2000 . By the third quarter of 2005 , the price of crude oil went as high as 60 US\$ per barrel.

As a result of the increase in oil prices, the real gross domestic product (GDP) picked up strongly to $10.7 \%$ in 2003 , but was estimated to have reverted to $4 \%$ in 2004 , with a projection of $6 \%$ in 2005, and 5\% in 2006. Despite the increase in the GDP, which should be an indication in the improvement of the standard of living of the people, Nigeria's social indicators are still low, with no evidence of sustained improvement in the quantity and quality of public services. For example, in relation to the population, the secondary and primary schools enrolments, and life expectancy as depicted in Chart 1.3, are still very low. Life expectancy has been 52 years on average for many years. In the United Nations (UN) Human Development Index (HDI), Nigeria was rated 152nd out of 175 countries in 2004. Government indicators show that the poverty rate has increased from $27 \%$ in the 1980 s to over $70 \%$ in 2003 (AFDB/OECD, 2005). There is not much difference in the literacy level compared to the early 1990s. Advancement in the social sector is very significant to the socio-economic development and poverty reduction of any country. Therefore good public policies on education, health and population are very important.

Chart 1.3: Nigeria: Population, Secondary \& Primary School Enrolment and Life Expectancy, 1994-1998

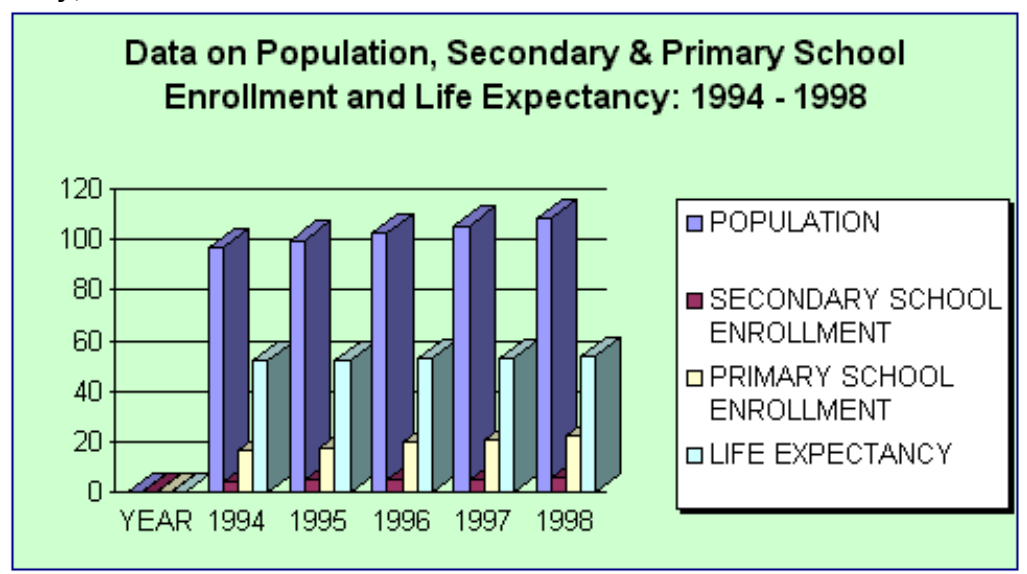

Source: Nigeria, Federal Office of Statistics (2001) as reported in

http://www.nigeriabusinessinfo.com/perormance-indicators.htm

The importance of education cannot be over-emphasized as it directly relates to a country's ability to generate scientific and technological advancement and alleviate poverty. The historical rise in workers' productivity in countries that made progress has been attributed to education and the rise in literacy rates. Greater employment opportunities and better salaries and wages often result from investment in education. The social values and attitudes to life are also positively affected (Osokoya 1995). Education coupled with good health translates to increase in better and productive labour force. These factors make up the composite measure referred to as the Human Development Index of a country, which reflects the wellness of that 
nation. In Nigeria, however, there has been a serious deterioration in the quality of service provision in these sectors. The basic facilities are ill maintained or non-existent, the personnel are inadequately supported and this had led to series of strikes, which continue to impede service delivery in this areas. In Nigeria, this may also be connected with the distribution of responsibilities among the various governments.

\section{Revenue Allocation and Financial Resources of Lagos State}

The success of any federal system depends on the federal, states and the local governments (that is the center and the sub-units), having the institutional capacities and resources to carry out their assigned responsibilities. Table 1.2 shows the distribution of responsibilities between the various governments in Nigeria. The table demonstrates that the state government is in charge of the basic services like education, health, and housing. These services are basic to a nation's socio-economic development and they are very expensive to provide (Olowu 1990). Economists like Todaro (1977) believe that provision of and accessibility to public and social services in developing countries leads to the reduction in corporate and individual poverty, transforms the social structure, contribute to the improvement of the standard of living, raise the human potentials of the populace, and eventually provide development for the society.

Table 1.2: Distribution of Responsibilities Among Nigerian Governments

\begin{tabular}{|c|c|c|}
\hline Federal Government & State Government & Local Government $^{10}$ \\
\hline $\begin{array}{l}\text { 1. Defence and Security } \\
\text { 2. External Relations } \\
\text { 3. Interstate and International } \\
\text { Roads } \\
\text { 4. Port facilities } \\
\text { 5. Railways } \\
\text { 6.Airport Facilities/ Aviation } \\
\text { 7. Power Supplies } \\
\text { 8. Communications } \\
\text { 9. Heavy Industries } \\
\text { 10. Higher Education }\end{array}$ & $\begin{array}{l}\text { 1.Secondary Schools and Higher } \\
\text { Education } \\
\text { 2. Health } \\
\text { 3. Water Supply } \\
\text { 4. Housing } \\
\text { 5. Lighter Infrastructure } \\
\text { 6. Agriculture } \\
\text { 7. Lighter Industries } \\
\text { 8.Town and Country Planning }\end{array}$ & $\begin{array}{l}\text { 1. Sewage Disposal } \\
\text { 2.Maintenance of feeder Roads } \\
\text { 3. Primary Education } \\
\text { 4. Market Stalls } \\
\text { 5. Rural Health } \\
\text { 6.Crafts and Small Industries }\end{array}$ \\
\hline
\end{tabular}

Source: Cabinet Office, Report of the technical Committee on Revenue Allocation (Lagos, 1977) As modified by the 1979 Constitution. Culled from Lagos State: Governance, Society and Economy (Olowu 1990 pg.22, Table 1.9)

Notes- The 1989 Constitution is operative in Nigeria for the period covered. It is very similar to the 1979 Constitution with some amendments. The distribution of responsibilities among Nigerian Governments is still the same as the one enunciated above.

However, as shown in Table 1.3, in the period after the civil war in Nigeria, the Federal Government has started receiving $80 \%$ allocation from the Federation Account as per the recommendation of the Dina/Gowon Commission in 1968. This represents a $100 \%$ increase from the revenue allocation the Federal Government was receiving in 1958. The state governments, especially during the civilian regimes, have always fought for a review of this asymmetrical allocation of resources and responsibilities between the various tiers of governments. This eventually led to the reduction of the Federal Government allocation from $75 \%$ to $55 \%$ in 1982 , and an increase for the state governments' allocations from $22 \%$ to $32.5 \%$, while the allocation to the local governments rose from $3 \%$ to $10 \%$. In 2001, the National Revenue Mo-

\footnotetext{
${ }^{10}$ In some countries the roles of the local governments are more elaborates than those of states, depending on the socio-political environments of the countries involved. Some federal governments also channel their expenditure through the state and local governments for the execution of their responsibilities.
} 
bilization Allocation and Fiscal Commission (NRMAF) proposed a revision to the revenue sharing formula of $41.5 \%$ for the Federal Government, $31 \%$ for the state governments, $16 \%$ for the local governments and $11.5 \%$ for the special funds. However, according to the Central bank of Nigeria Annual Reports (1980-1983, Lagos), the actual transfers from the Federation accounts between 1981-1983 were $61.5 \%$ for the Federal Government, $29.5 \%$ for the states and $9.0 \%$ for local governments. No allocation was made to Special Funds.

Table 1.3: The Search for a Viable Revenue Sharing Formula

\begin{tabular}{|c|c|c|c|c|c|c|}
\hline \multirow[t]{2}{*}{ Year } & \multirow{2}{*}{$\begin{array}{l}\text { Revenue Allocation } \\
\text { Commission }\end{array}$} & \multicolumn{4}{|c|}{ Allocation of the Federation Account (pct.) } & \multirow[b]{2}{*}{ Derivation Formula** } \\
\hline & & FGN & States* & LGAs & $\begin{array}{l}\text { Special } \\
\text { Funds }\end{array}$ & \\
\hline 1958 & Raisman & 40 & 60 & 0 & 0 & 50 \\
\hline 1968 & Dina/Gowon & 80 & 20 & 0 & 0 & 10 \\
\hline 1977 & Aboyade & 75 & 22 & 3 & 0 & 10 \\
\hline 1982 & Okigbo & 55 & 32.5 & 10 & 2.5 & 10 \\
\hline 1989 & Babaginda & 50 & 24 & 15 & 11 & 10 \\
\hline 1995 & Abacha & 48.5 & 24 & 20 & 7.5 & 13 \\
\hline 2001 & NRMAF (proposed) & 41.5 & 31 & 16 & 11.5 & 13 \\
\hline
\end{tabular}

Source: Nigeria: State and Local Governance in Nigeria. The World Bank AFTPR, Africa Region, July 23, 2002.

*The portion of the Federation Account allocated to the states has been allocated on the bases of five criteria: equality (equal shares for all the states), population, social development, land mass and terrain, and internal efforts at generating revenue. Historically, the bulk of the allocation (usually 70 percent) has been on the basis of equality and population.

**The derivation formula is the percentage of the revenue states may retain from the taxes on oil and other natural resources produced in the state.

Tables 1.2 and 1.3 demonstrate the way basic public services are administered and the politics of revenue allocation. Consequently, the ability of state governments to fulfill the roles of socio-economic development and nation building is sometimes hampered by the Federal Government. Many centrally imposed legal restrictions lead to hostile relations between the two levels of governments. The pattern of intergovernmental relationship is still immature, hostile and competitive. In Nigeria "during the four years of the Second Republic (19791983), each level of government was jealously guarding its constitutional responsibilities as evidenced by the large number of court cases between the federal and state governments in the four years of the civilian governments. The fratricidal nature of partisan competition tends to aggravate the situation further. It must be noted, rather sadly, that similar federal-state crises led to the demise of the First Republic" Olowu, (1990:10).

This tension may be connected to the Federal Government's overall management of the national economy ${ }^{11}$. The Nigerian constitution gives the state governments the onerous responsibility to provide the large parts of social services. However, the heavy reliance of state governments for monetary transfers from the Federal Government means that their degree of financial autonomy tends to be quite limited. Furthermore, the Federal Government has in

\footnotetext{
${ }^{11}$ The change in the national economy was also a result of the huge oil wealth of the late 1960s and early $1970 \mathrm{~s}$ whose tax revenues were mainly retained and controlled by the Federal Government. The oil-boom gave the Federal Government the opportunity to assume social and economic responsibilities that were earlier the exclusive preserve of the regions. Being a military government the federal might was used to transfer primary education, under the Universal Primary Education Scheme to its control with both legal and fiscal backing. Although the state governments still have control over the public service and invariably the social development of the country but there is a lot of influence in the execution of these responsibilities and the Federal Government now gives the states non-statutory grants to supervise its priorities in the areas such as agriculture, education, urban roads, and basic health services (Olowu 1990).
} 
many respects tampered with the independent, profitable, elastic and redistributive revenue resources of the state and the local governments (for example, game taxes, personal income taxes, and value added taxes (VAT)). Although, the 1982 revenue allocation formula tried to ensure that state governments receive more nationally collected revenues through statutory grants.

Nevertheless, there remain considerable fiscal imbalances in the distribution of governmental responsibilities and powers given to the state governments. In Lagos State, the statutory and non-statutory grants from the Federal Government in 2000 were about $47 \%$ of the Actual Recurrent Revenues. In 2000, the reliance of the state government upon federal transfers had reverted to a level similar to the one at the State's inception. Revenue allocation from federation accounts in 1968 was $47.1 \%$, while it was $38.6 \%$ in 1980 , only to rise to $47 \%$ in 2000. Since almost half of its recurrent revenue is from the Federal Government, the state can be said to have experienced a loss of financial autonomy.

Loss of financial autonomy has many implications for both the state and local governments. One of the negative effects of this is the absence of genuine independent decisionmaking. According to Smith (1982) local governments in Nigeria are heavily dependent upon central grants, and this can be withheld if local expenditure is regarded as "wasteful, unreasonable or in conflict with central policies.... These controls have tended to be drawn into a punitive style of central supervision motivated by partisan interest as much as a concern for fiscal irregularity."

The Federal Government stifled and delayed the release of grants to Lagos State for several months in 2004 and 2005 because the state government had increased the number of local governments from 20 to 50 in 2003, without the approval of the Federal Government ${ }^{12}$. The grants to the state were withheld as a punitive measure. In view of the heavy reliance of state and local governments on the monthly federal allocations, this had heavy consequences. Local government workers were not paid for months, and public services that were supposed to be provided were abandoned. Any delay in the release of federal grants leads to cash flow problems for local and state governments affecting the payment of salaries, pensions and the provision of public service.

Furthermore, Lagos State is the most highly urbanized state in Nigeria and this does not reflect in the gross allocations from the federation accounts. The 1991 Census defines an urban center as a settlement with 20,000 inhabitants or more. With a population of over $5,725,116(6.4 \%)$ in 1991 , and growing at a projected rate of $2.8 \%$ per annum, Lagos State easily qualifies. The state has the largest number of urban dwellers $(94 \%)$, which is far in excess of the national average, according to the National Population Commission (2005). The density of people per $\mathrm{km}^{2}$ is 1,712 , an obvious case of over-population and over-urbanization. The inability of the state government to provide adequate infrastructural needs for the people has led to the growth of slums. In view of the important role this State has played in the socioeconomic and political development of Nigeria, it is believed that the State should receive a greater allocation from the Federation account.

Table 1.4 reflects the 1991 census in terms of population, area $\left(\mathrm{km}^{2}\right)$ and density (per $\mathrm{km}^{2}$ ); and approved $30 \%$ population indices used for the gross allocation for the states in 2001 of the two most populated states in Nigeria, Lagos State and Kano State. Although the percentage differences in population is about $1.5 \%$ in 1991 and let us assume that the population of the two states is growing at a similar rate, however, the percentage difference in gross allocation given to the two states in 2001 was about $8 \%$.

\footnotetext{
${ }^{12}$ Debates in the popular press ascribe federal action to punitive policy but it will seem that the Federal Government had based its action on legal grounds.
} 
Table 1.4: Lagos versus Kano: Highly Populated States in 1991 and Gross Allocation in 2001

\begin{tabular}{|c|c|c|c|c|c|c|}
\hline States & $\begin{array}{l}\text { Area } \\
\left(\mathrm{km}^{2}\right)\end{array}$ & $\%$ & Population & $\begin{array}{l}\text { Density } \\
(\text { per km²) }\end{array}$ & $\begin{array}{l}\text { Population } \\
(30 \%)\end{array}$ & $\begin{array}{l}\text { Gross allocation in } \\
\text { Naira (2001) }\end{array}$ \\
\hline Lagos & 3,345 & 0.36 & $5,725,116$ & 1,712 & 0.4651 & $677,901,866.16$ \\
\hline Kano & 20,680 & 2.24 & $5,810,470$ & 218 & 0.4721 & $736,762,170.42$ \\
\hline
\end{tabular}

Source: National Population Commission (2005), and Lagos State Ministry of Finance (2002)

Furthermore, the gross allocation in December 2001 to the 44 local governments in Kano State was 824,721,043.63 Naira, while Lagos State received the sum of 516,048,420.01 Naira for its 20 local governments (Lagos State Ministry of Finance, 2002). There is also a huge disparity in the population density ${ }^{13}$ of the two states. Lagos with 1,712 per $\mathrm{km}^{2}$ compared to 218 per $\mathrm{km}^{2}$ for Kano State. Successive governments of Lagos State have consistently pointed out this evident disparity but the status quo remains.

The use by the Federal Government of the same criteria for resource allocation policies in the attempt at uniformity overlooks the cultural and historical differences among the constituent states. The Federal Government does not recognize the peculiar nature of Lagos State in funds allocation. For instance, Lagos State is home to people from all over the country who send their children to Lagos especially because of its free education policy and other social benefits. The state also attracts people because it is an industrial and commercial center. The case of Lagos and Kano States illustrates not only imbalance between resources and constitutional responsibilities, it demonstrates how external political and historical forces undermine state capacity. It also shows how political and constitutional decisions made at a different era and under different regimes take on a life of their own. The research therefore examines how fiscal and political centralization affects effective policy formulation and implementation of Lagos State Government.

Also, the state government's inability to generate sufficient revenue from its constituencies may lead to lack of accountability to the populace because they do not provide the revenue base. There is no justification of expenditures to the populace or the government responsiveness to the local needs. According to Rondinelli (1983:49) lack of financial autonomy "reduces the burden, but increases the dependence of, local authorities, who generally neither impose taxes nor have to justify to local populations how money is spent". This type of attitude from the government adversely affects the provision of public services to the populace. As well, the heavy reliance of the state and local governments on federal statutory and nonstatutory grants makes planning government expenditure virtually impossible because the national reliance on oil is extremely unstable, as prices and production oscillate on monthly basis. Although the Nigerian Government operates a federal system, the financial dependence of the state governments however, increases the exposure to central command, lack of independence and the continual attachment to the economic fortunes of the central government.

\footnotetext{
${ }^{13}$ The last census carried out in Nigeria was in 1991. However, another census exercise was carried out in March 2006, but its results are yet to be published.
} 
Table 1.5:Lagos State Government: Recurrent Revenues 1968-2000 ( Million and Percentages)

\begin{tabular}{|c|c|c|c|c|}
\hline Year & Personal Income tax & $\begin{array}{c}\text { Federal grants } \\
\text { (Statutory and non } \\
\text { statutory) }\end{array}$ & $\begin{array}{c}\text { Others } \\
\text { (Fines, Fees, } \\
\text { Licenses, Rents) }\end{array}$ & Total million \\
\hline 1968 & $\begin{array}{c}9.28 \\
(34.2 \%)^{*}\end{array}$ & $\begin{array}{c}2.77 \\
(47.1 \%)\end{array}$ & $\begin{array}{c}5.05 \\
(18.6 \%)\end{array}$ & $\begin{array}{l}27.10 \\
39.35\end{array}$ \\
\hline 1970 & $\begin{array}{c}15.76 \\
(40.0 \%)\end{array}$ & $\begin{array}{c}14.71 \\
(35.0 \%)\end{array}$ & $\begin{array}{c}8.88 \\
(25.0 \%)\end{array}$ & 247.5 \\
\hline 1980 & $\begin{array}{c}97 \\
(39.2 \%)\end{array}$ & $\begin{array}{c}95.6 \\
(38.6 \%)\end{array}$ & $\begin{array}{c}54.9 \\
(22.2 \%)\end{array}$ & $21,767.9$ \\
\hline 2000 & $\begin{array}{l}8,426.5 \\
(38.0 \%)\end{array}$ & $\begin{array}{l}10,361.3 \\
(47.0 \%)\end{array}$ & $\begin{array}{c}3,080.1 \\
(15.0 \%)\end{array}$ & \\
\hline Total & $\begin{array}{l}8548.54 \\
(39.0 \%)\end{array}$ & $\begin{array}{c}10,474.38 \\
(47.0 \%)\end{array}$ & $\begin{array}{l}3148.93 \\
(14.0 \%)\end{array}$ & $\begin{array}{l}22081.85 \\
(100.0 \%)\end{array}$ \\
\hline
\end{tabular}

Source: Lagos State Government Budget Estimates 1968-1980, Olowu (1990:93-94 Table 4.1 A\&B); and Report of the Auditor General on the accounts of the Lagos State Government October 2001.

* The figures in parentheses are percentages and they have been rounded up, so they may not be exactly 100 .

From Table 1.5, it can be observed that at the inception of Lagos State in 1968, about $34.2 \%$ of the state's financial resources came from workers' personal income tax. Through the years, the state was still able to maintain about $40 \%$ revenue from the salaried workers because the state improved its revenue collection from the public and salaried private sector workers. Still, there was a continuing revenue shortfall from other sources such as fines and fees, licenses, and rents on government properties. These were at $18.6 \%$ at the inception of the State in 1968. By 1980 it has risen to $22.25 \%$ and twenty years after had slipped to $15 \%$ in 2000 . This shows that between 1980 and 2000, the state sources of revenue have reduced in terms of taxes and other revenues, while the grants from the federation grants have increased from $38.6 \%$ to $47 \%$. This is at variance with period in the early 1980 s when the government made a "deliberate attempt to diversify the state's resource base from the usual dependency on either the grants or taxes imposed on the salaried classes" Olowu, (1990:93) ${ }^{14}$. There have been many reasons attributed to this.

According to Rondinelli (1990), the prevalent lack of perceived benefits contributes to African urban-dwellers unwillingness to pay taxes. The common belief is that tax evasion is rampant even in Nigeria because residents do not think that they are receiving the quantity and quality of services they are paying for. However, Olowu, (1990) opined that both state and local governments revenue fell, in relative and absolute terms, because the national revenue sharing formula lacked any incentive for their raising taxes; as a result local governments were implicitly encouraged to drop such revenue sources as community taxes, property rates and user fees.

Aside from disincentives for the state and local governments to improve on their revenue generation, insufficient yield is an obvious deficiency in the taxation system. According to Newberry (1988), one of the practical obstacles to tax yield in developing countries is the lack of administrative capacity, lax enforcement and compliance, which makes the State revenues always in a state of fluctuation. In his contribution, Goode (1990) believes that funda-

\footnotetext{
${ }^{14}$ Lagos State Actual Recurrent Revenues and sources 1968-78

Source: Lagos State Government as reported by Olowu (1990:93 Table 4.1A); Lagos State Government: Actual Recurrent Revenue 1968-78.
} 
mental staff competence, clearly defined tax legislation and an effective method of enforcement are needed in other to solve the acute problems of taxation.

Lagos State Government has the opportunity to realize a high tax yield because of the strategic position it occupies as the industrial and commercial hub of Nigeria, with over $50 \%$ of the total industrial and financial institutions located in the state. However, from Table 1.5 it can be seen that the Lagos State Government has consistently had a shortfall in estimated revenues. Except for statutory allocation from Federal Government, every area of revenue generation recorded shortfalls for the period that ended in December 2000.

The issue of financial resources is one of the problems that the government faces in the process of giving public service deliveries to the populace. Tax evasion and avoidance are serious dilemmas facing Lagos State, and the underlying constraints are institutional, structural, political and cultural. Much has to do with public attitude and perception, and the government capability to give good public service. The research tries to study how the political leaders are able to formulate and implement public policy in the face of this asymmetrical revenue and dwindling financial resources.

\subsection{The Choice of Lagos State Civil Service}

Although the terms public service and civil service are sometimes used interchangeably, they have different meanings. Public services are the services that the government delivers to the public. They cover the services of the government in its broadest sense - i.e. public utilities, financial institutions, medical, teaching, judiciary, military and the security forces. Organizations dedicated to the delivery of these services are referred to as Public Services or Public Service Organizations -PSO (Adamolekun \& Olowu, 1999:17).

The organization and functioning of civil services vary the world over and consequently, the definitions differ. In Africa, there is no consistent definition. This makes assessment and comparison of the sector difficult. For the purpose of this study, the Westminster model definition that Nigeria inherited from the British is used. In this model, civil servants are the body of permanent officials appointed to assist political executives in formulating government policies. In a second sense, civil service refers to the ministries and departments within which specific aspects of government work are carried out (Adamolekun, 1999). The civil service is conceived as an instrument of governance, and an organ of employment and policy-making (Olowu, 1999). Although the centre of this research is civil service and its focus is on policy management, however the public service organs outside the civil service are included in terms of policy impact assessment.

The choice of Lagos State Civil Service as a case study is appropriate because it is the most developed and urbanized state government in Nigeria. Although Lagos became a state in 1967 with its capital in Ikeja, it continued as the capital of Nigeria until 1991 when the capital relocated to Abuja. It is one of the fastest growing urban areas in Africa with all the attendant problems associated with urbanization in a developing country. The state grappled with overpopulation and this inevitably stretched the provision of public service deliveries to its limit. The major problems that confronted the political and administrative leaders are how to mobilize their internal and external resources in the effective provision of the public service deliveries. The ability of the executive leaders to develop successful social and economic policies is in large measure related to the level of the existing institutional capacity. The research therefore studies the abilities of the various leaders to harness the resources at their disposal in order to succeed in the face of the economic challenges in the country.

The Lagos State Government started operations on April 1, 1968. It was one of the 12 states created by the Federal Military Government from the three regions in 1967. Lagos State can therefore be regarded as one of the oldest of the now 36 state governments in the Federal 
Republic of Nigeria. The nucleus of the government consisted of a number of skilful and knowledgeable officials posted or seconded to the newly created State from the Federal Ministries of Finance, Education, Health, Agriculture, Internal Affairs and Labour, the Western Region Ministries and the Lagos City Council (Olowu 1990).

At its inception in 1968, the Lagos State Civil Service inherited the Westminster model that established the principle of meritocracy or the career of the open talent. Recruitment was based on competition without bias for sex or religion. For their political neutrality, loyalty and service, the civil servants enjoyed good and attractive service conditions, including free or subsidized accommodation, housing loans, official cars or car loans (depending on the grade levels), good career prospects, and equally good retirement benefits. All these factors initially made Lagos State Civil Service one of the best amongst the 36 states in Nigeria. However, policies adopted by the governments of the state over the years have made people to query this claim, a challenge this study takes on.

Compared to the other states, Lagos State is one of the most economically viable. It was the administrative and political nerve-center of the Federal Republic and attracted other activities, such as the establishment of the majority of large-scale manufacturing and other economic institutions, different occupational and cultural expressions, and the biggest and arguably the busiest port in the coast of West Africa. Lagos State therefore generates relatively considerable revenues from income taxes of industries as well as from individuals, fines and fees, licenses, earnings and sales, and so on. The government used its finances to implement its public services programmes and maintain a highly skilled workforce.

On the demand side, the government could compete with other public and large-scale private sector organizations in recruitment and retention of skills by its practices and motivation. In addition, the government training policy and management made it possible to supply a skilled and productive workforce. At the state's early stage of development, the civil service had such tremendous credibility that the populace believed that whatever the State Government or the State Civil Service did not do, could never be done. In its early years, it can be asserted that the Lagos State Civil Service recorded a modest institutional capacity and a good administrative system (Olowu 1990).

However, inspite of its considerable progress in the area of public service deliveries relative relationship to other state governments, in the late 1970s the state began to experience problems with basic facilities such as water, housing, and environmental conditions. This was mainly due to the oil boom that induced urban migration and a population rate of metropolitan Lagos was almost four times the annual rate of Nigeria's other urban areas. According to the 1991 census $^{15}$, the total population of Nigeria in 1991 was 88,992,220 with 44,529,608 males and 44,462,612 females in almost equal ratio. Kano State was the most populous state with a population of 5.8 million (7\%) followed closely by Lagos State with a population of 5.7 million (6\%) (National Population Commission 2005).

The report by the National Population Commission for population size and spatial distribution reveals that about 25 percent of the population is concentrated in the southwest with a total land area covering no more than $12 \%$ of the country. At the national level, the proportion of the population living in urban areas was about 36\%, up from 19 percent in 1963 . The states with the largest proportions of urban dwellers, far in excess of the national average are Lagos (94\%), Oyo (69\%) and Anambra (62\%). The population of Nigeria is still predominantly rural, with only about $36 \%$ living in the urban areas. The average population density for the country in 1991 was 96 persons per square kilometer. The most densely populated state is Lagos with 1,712 persons per square kilometer, and $94 \%$ of its populace living in the urban area of the state (National Population Commission 2005). This astronomical growth in

\footnotetext{
${ }^{15}$ Nigeria conducted another census in March 2006. The result is yet to be published during the writing of this book.
} 
the population of the state became problematic due to poor civic planning, and the apparent lack of reliable socio-economic data that hinders the projection of the state's public service deliveries.

For instance, despite concerted efforts by the Lagos State Government, projections on its housing developments are inadequate. Shanties and slums spring up in some of the urban areas. The roads are inadequate for the numbers of cars, and this leads to perennial traffic congestion on the roads. In combination with the heavy traffic load, much of Lagos State is waterlogged and so the roads are in constant need of repair. The strain is also apparent in other public service deliveries, including health, education and environmental services.

\subsection{Research Questions}

Although since independence, the governments have attempted to build up a "quality civil service", as the military and civilian participation in government has influenced this key institution. While it is difficult to separate politics and administration, the political leadership should be responsible for providing policy guidelines, while the administrative bureaucratic arm executes policies. The adequacy or availability of information about a problem, the perception or the judgment of the policy-maker, the timing, the particular historical and other binding social factors all affect the quality of the public policies. Apart from the performance of political leadership in formulating and implementing public policies, the institutional capacities of the public service that execute these policies are equally of great importance. Ultimately the result is evident in the level of public service delivery that is provided to the citizenry. However, due to public skepticism and criticism of the quality of service delivery, coupled with the problems of public accountability and bureaucratic inertia especially during the late $1980 \mathrm{~s}$, the various governments attempted to revamp the civil service through the introduction of different reforms. These observations bring us to our research interest on the nature and direction of the development of the Lagos State Civil Service.

\section{The central research question is:}

"To what extent have different forms of political leadership represented by authoritarian/military and democratic/civilian governance influenced public policy performance in Lagos State, Nigeria?"

\section{The following sub-questions are addressed:}

- Research Question 1: "How has the political leadership's influence on the administrative leadership impacted the performance of the civil service?"

- Research Question 2: "Does the State Government have the institutional capacity for effective civil service performance?"

- Research Question 3: "Have the recent reforms of the civil service impacted negatively or positively on performance?"

\subsection{Research Proposition}

Deriving from the above, we propose one main proposition and three sub-propositions: 


\section{Main Proposition:}

Political leadership (authoritarian or democratic) influence on public policy impacts on the performance of the Lagos State Civil Service, Nigeria.

\section{Sub-Propositions:}

- Political leadership influence on the administrative leadership impacts on the performance of the civil service;

- Institutional capacity affects civil service performance;

- Recent reforms of the civil service have impacted negatively on performance;

\subsection{Research Objectives}

The broad objective of the study is to examine the performance of successive state-level leadership (which had a mix of authoritarian and democratic governance) in the implementation of government policies. The second component of the research is to study the relationship between the political and the administrative leadership and its impact on the performance of government. The third segment evaluates institutional capacity as it affects civil service performance. Finally, the researcher wants to understand the impact of the various civil service reforms on the performance of the Lagos State Civil Service.

\subsection{Significance of the Problem and Justification for the Study}

The study developed from the researcher's interest to understand the factors that led to the presumed deterioration of the performance of the Lagos State Civil Service. As an indigene of the state, the researcher grew up observing how successive governments tried to implement their various public services programmes. However, by the late 1980s there were complaints and sustained criticism about the quality of state's civil service. There is evident qualitative decline in the standard of living of Nigerians particularly for residents of cosmopolitan cities like Lagos ${ }^{16}$. Proponents of decline find evidence in the persistent growth of slums resulting from rapid urbanization without the requisite expansion of services such as roads, schools and hospitals. As an indigene and a senior officer with the state, the researcher hopes the result of the research will answer some of the questions relating to the sources of the perceived decline of a once highly regarded institution in the performance of its service delivery.

Second, this is the first empirical study of its kind that systematically examines the institutional roots of the performance of the Lagos State Civil Service from inception to date. The researcher's position as managerial level staff in the state gave her relatively easy access to data and personnel that helped facilitate the research.

Third, this study attempts to determine whether the reforms had adversely affected the evolution of a strong civil service. The outcome of the study should assist in designing informed policies reversing the effect. Finally, it is hoped that the result will contribute to a reevaluation of the institutional capacity profiling of the Nigerian Public Service, and the role of the executive leadership.

\footnotetext{
${ }^{16}$ The average per capita income has declined over time while various measures of poverty show that a higher proportion of Nigerians now live below US1 dollar a day compared with twenty-five years ago. This affects both rural and urban dwellers and Lagos State is no exception. Chart 1.1 shows the GDP Per Capita (US\$) for Nigeria: $1981-2003$
} 


\subsection{Research Design and Methodology}

The research interest focuses on governance and the bureaucratic order of the public service and the influence of the leadership, especially the political, upon it. As it is difficult to capture the historical and experiential reasons for these developments from official documents for all the states of Nigeria, the researcher employs a case study that focuses on one of the 36 states as her research design. It is important to understand certain processes that occurred in the system both under the authoritarian/military and democratic/civilian governments. According to Gummesson, (2000), the case study is becoming a suitable scientific tool in management research, especially to obtain "an in-depth understanding of the mechanism of change". Case studies are exploratory and descriptive in nature and use both qualitative and quantitative data collection methods, thereby giving the study analytical rigor. The emphasis of the research questions is to establish what, how and why the systems of operation in the Lagos State Civil Service evolved as they did in order to understand and improve on the level of its performance.

\subsection{Research Design}

The importance of the research design is to develop an "overall plan for relating the conceptual research problem to relevant-and doable-empirical research" (Ghauri et al., 1995:26). Therefore, the research questions can be adopted into an analytical framework that helps answer these questions in the most effective way possible in view of the various constraints encountered by the researcher, in terms of time, money and expertise. The analytical framework work is based on the assumption that political leadership has considerable influence on the formulation and implementation of public policies, and the institutional capacity of government. To succeed, civil service reforms also need the political leaderships' implicit support for the effective performance of the civil service. As noted earlier the home-grown reforms and the one adopted at the request of the international financial and donor organizations are different in motivation, structure and methods of implementation.

\section{Analytical framework}

Many countries are faced with challenges in their public sector that require urgent solutions that are transformational in nature. A recent reforms attempt in public administration is the New Public Management, which emphasizes accountability, transparency and performance (Polidano 1999, Larbi 1998). Different researchers discuss the various issues they feel are useful for the implementation of $\mathrm{NPM}^{17}$. Manning (2001) affirms that motivation and capability are essential. According to him, a government may have the motivation to reform, but lacks capability. His model on "Motive and Capacity for Public Management Reform" adapted a-four ideal typical models from Girishankar (2000) and World Bank (2000), where one end of the continuum is a government that is "incapable and unmotivated with high state capture and administrative corruption, and with little administrative competence and nonparticipatory governance" and the other end is one that is "capable and motivated". The usefulness and success of NPM depends on which side of the axis the government is.

NPM was regarded as the "one-best way" (Gendron et al., 1999). Many financial institutions and donor agencies applied the elements of NPM as an extension of the reforms being applied in their home countries. Critics believe that application of NPM was irrespective of

\footnotetext{
${ }^{17}$ Some of the various opinions are extensively discussed in the literature review.
} 
the "capability" and the "motive" of such governments. The researcher finds the work of Manning, (2001) on the "Legacy of NPM in developing countries" relevant in this respect.

In Manning's Public Management Reform Model, the government should be capable through the entrenchment of the "Old Public Discipline" of bureaucracy that emphasises meritocracy (see Table 2.1 for the elements of the merit system); and motivated with medium state capture, medium administrative corruption, administrative competence and participatory governance. Only a capable and motivated government can achieve improved civil service performance either through NPM or through other traditional reforms. Economic interest should be deconcentrated and public expectation raised through service delivery.

Manning (2001) reviews the legacy of the NPM and argues that in countries with high public expectations of the government, these expectations motivate the government to improve its service delivery, especially when the government concerned has the capability entrenched in the Old Public Discipline. He observes that the impact of the NPM in developing countries has been modest, mainly because public expectations in these countries are low, and the citizenry do not think it is worth the effort to complain, as they are not likely to be heard. This is possible because of the absence of participatory governance in such countries, where the ruling governments are more interested in the complaints of the donor agencies. In the developed countries, however, NPM is used as a political weapon to pressurize government into better performance. Secondly, the Old Public Discipline, which denotes capacities, is lacking in these countries. Thirdly, due to cuts in budgetary expenditures, the impact of the NPM in terms of efficiency has been marginal even in the developed countries that have adopted it.

While the research relates to the assumption of Manning, (2001), it deviates from it on these grounds. Manning believes that an incapable and unmotivated government characterised with high state capture, high administrative corruption, reduced administrative competence, and non-participatory governance, and 'technocratic' public management is doomed. In these situations, the governed do not have any say in the performance of government, and ultimately the citizenry do not expect much from the service delivery.

However, Nigeria has had both democratic and military governments with high state capture and non-participatory governance characterizing these two types of governments. The question now remains, why some regimes have performed relatively better than the others. The researcher believes that the role of the leaders, be they authoritarian or democratic, is very important in the performance of civil service. In other words, the executive or the government is constrained or otherwise through the leadership qualities. The influence of the leaders, especially the Executive Governors (military/autocratic or civilian/democratic) on institutional capacity will ultimately influence other militating factors of performance like, public policy and the civil service reforms.

The analytical framework in figure 1.1 attempts to connect the different research questions in order to determine the dependent variable, civil service performance. The central research question is "To what extent have different forms of political leadership represented by authoritarian/military and democratic/civilian governance influenced public policy performance in Lagos State, Nigeria?" This analytical framework assumes that the political leadership influences the quality of the formulation and implementation of public policies. As well, the institutional capacity influences the type of public policies that will be implemented by the government. These two intervening variables will also affect the initiation of civil service reforms. The leadership qualities of the Governors influence these variables collectively and individually, and this ultimately affects the performance of government. The Research Model of the performance of the Lagos State Civil Service (Figure 1.1) depicts this. 
Figure 1.1: Research Model of Organizational Performance: Lagos State Civil Service ${ }^{18}$

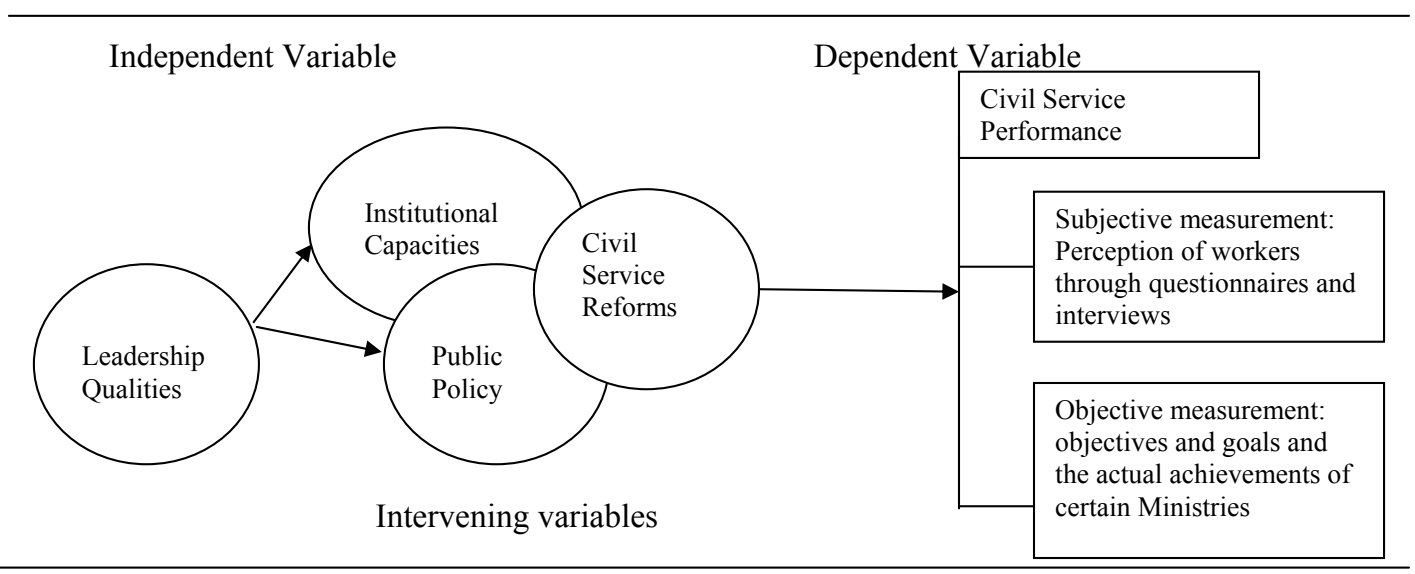

\section{Research question 1}

The analytical framework in figure 1.2 was used to analyze the research question one, as to how the political leadership influence on the administrative leadership has impacted the performance of the civil service. This question studies the influence of the political leadership on the administrative leadership and focuses on the impact of these relationships on the performance of the civil service.

Figure 1.2: Analytical Framework for Research Question 1

Independent variable

Intervening variable Dependent variable

\begin{tabular}{|l|l|l|l|}
\hline \multirow{2}{*}{$\begin{array}{l}\text { Political } \\
\text { Leadership }\end{array}$} & $\begin{array}{l}\text { Performance } \\
\text { Administrative } \\
\text { of the Civil } \\
\text { Service }\end{array}$ \\
\hline
\end{tabular}

\section{Research Question 2}

The analytical framework in figure 1.3 was used to analyze the research question two on the relationship between institutional capacity of government and recent civil service reforms and their impact on civil service performance. The quality of the institutional capacity of government will determine the types of reforms required. Additionally, the civil service reforms are attempts to correct the problems and strengthen the institutional capacity, but the application can affect the institutional capacity positively or negatively. Either way will also affect the civil service performance positively or negatively. This leads us to Research Question 3.

\footnotetext{
${ }^{18}$ The use of intervening variables for such concepts as "civil service reforms" and "public policy" is deliberate so that they can be observed operationally through descriptive statistics.
} 
Figure 1.3: Analytical Framework for Research Question 2

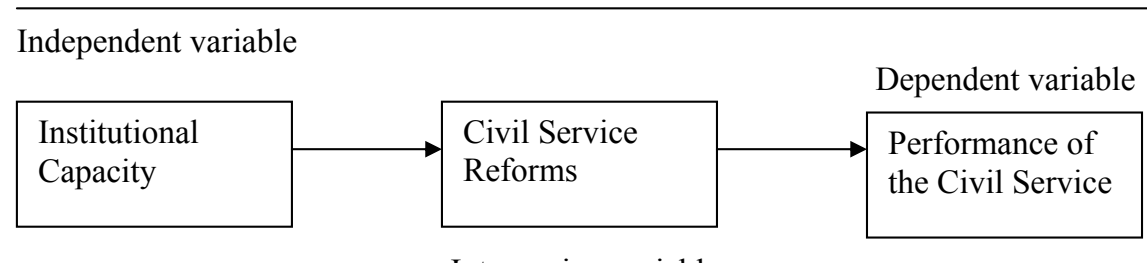

Intervening variable

\section{Research Question 3}

Figure 1.4: Analytical Framework for Research Question 3

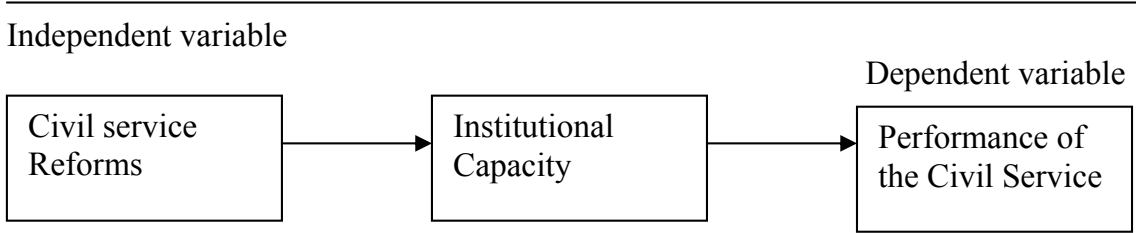

Intervening variable

Civil Service Reforms are attempts to correct the problems and strengthen the institutional capacity of civil service through professionalism, accountability and transparency. However, if there have been poor diagnosis of the problems, the therapy will be faulty. Therefore the Civil Service Reforms applied may adversely affect the institutional capacity and this will ultimately affect the performance of the civil service.

\subsection{Definition of Concepts}

Using these analytical frameworks certain key words emerge. In order to guide the study, it is pertinent to define the concepts that are used in the analytical frameworks.

\section{Political leadership}

The study of leadership is one of the most widely studied management subjects, although it is still one with the least consensus amongst researchers and practitioners. The term leadership has no set definition (Bass, 1990), as the most important qualities of successful leadership can greatly vary among individuals. However, Bass affirms that definition of leaders usually depends on the raison d'être of the study. According to Robbins (2003), however, leadership is about controlling and directing an organization or group towards a predetermined goals. This could be accomplished through having a vision, communicating the vision and motivating the group to achieve the vision. Studies have shown that leaders make the difference in the performance of organizations. The right leader translates resources or assets to production, which ultimately determines the survival or success level of that organization. The overall organizational effectiveness and performance may not be due to poor administrative system, but poor 
organizational leadership. Therefore, leadership is about "doing the right thing" (Dobbs and Field, 1993).

For the purpose of this research, discussions would be in terms of political and administrative leadership. These are the actors that should be able to guide, direct, influence and motivate people to achieve the organizational goals. For political leadership, this would be the state governor either democratic/civilian or authoritarian/military. Governors are the executive political leaders that rule over a state. Under a military regime, the Head of State or President who is the Commander of the Armed Forces of Nigeria usually appoints a military Governor. Military Governors were from the Army, Navy, Air force or the Police. However, during a democratic regime, the electorate usually votes for the civilian Governor. Both the military and the civilian Governors work with the same state and non-state (private, nongovernmental organizations and communities) structures, and tackle common problems in governance.

\section{Administrative leadership}

The Lagos State Public Service divides into three main categories as follows:

- Junior staff (grade levels 01-06)

- Middle level or intermediate staff (grade levels 07-12)

- Senior Management staff (grade levels 13 -17)

The junior staff comprise mainly of clerks, office attendants, drivers, messengers and so on. The other two categories cut across both the professional staff (account officers, accountants, engineers, medical officers, etc.) and generalized specialists like administrative staff. The study focuses specifically on the political leadership who are more in conflict with the top administrative staff, than other professional staff (Adebayo, 2001; Balogun, 2002). Top management in the civil service exerts considerable power over the decision-making machinery and assists the political leadership in making and implementing policies. Like senior managers in other organizations, they influence decisions made over issues including capital and budgetary allocations, recruitment, retention and retirement, and other strategic policies. These crucial issues contribute to the survival of organizations. The study assessed senior management levels, that is, grade-level 13 and above, in terms of recruitment, transfer, posting, promotion, appointment amongst other things in view of the vital role they play in determining the quality of service performance.

\section{Leadership qualities}

Bass, (1990), opines that the definition of a leader varies according to the purpose of the study. For example, Adamolekun (1988) believes that an effective leader must have the following qualities- "visionary/messianic/moralistic orientation/symbolic politics" in his expose on "Political Leadership in Sub-Saharan Africa: From Giants to Dwarfs". Robbins (2003) associates leadership with having a vision, and the ability to communicate that vision and influence groups to move in a desired direction in order to achieve a desired goal.

The use of a structured questionnaire minimized the potential for subjectivity, as introduced through the researcher's biases in the formulation of leadership qualities. Objectivity was achieved through a Likert 5-point scale that measured the qualities of successful and unsuccessful leaders as perceived by the followers. In order to give credence to the research, a quantitative analysis of the data was performed. The research examined the leadership qualities of executive Governors (authoritarian/military and democratic/civilian) in terms of being successful or unsuccessful. For the purpose of this study, a successful leader would have some or all of the following attributes and conversely, unsuccessful leader qualities would be opposite of this: 
- They enforce discipline, rules and regulations;

- They exhibit self-discipline and moral rectitude;

- They are people-oriented, instituting policies that will affect the welfare of people positively;

- They have a good sense of judgment and instinctive caution;

- They have a reservoir of knowledge on the history of the civil service and they use it effectively;

- They have a realistic assessment of the institutional capacity of the Civil service;

- They have a strong vision and mission for the development of the Civil service and the society;

- They have the ability to lead and inspire the staff through their hard work;

- They are brilliant and upright ;

- They encourage training and development;

- They are great achievers and dare to make changes;

- They demonstrate a high sense of transparency and integrity;

- They have good moral character that people want to emulate.

The study examines how the Governors' leadership qualities affected institutional capacity, public policies and reforms carried out by the state.

\section{Institutional capacity}

We used institutional capacity to denote all human and non-human assets. Human assets are the knowledge, skills and experience of humans to manage technical and non-technical assets, to formulate, interpret, and implement policies, laws and the constitution. The research used the "Old Public Discipline" or Merit System (Olowu and Adamolekun, 1999) to determine this quality. As presented in Table 2.1, the following salient features are necessary:

- Recruitment and promotion based on merit;

- Competitive pay (reference to inflation, private sector pay, or specific job requirements);

- Mandatory training and retraining;

- Decent working environment (space, tools, supportive infrastructure);

- Decent pension;

- Propertylessness;

- Political neutrality;

- Security of tenure or renewable contract;

- Accountable performance.

The above features were defined as follows:

- Recruitment: the seeking and attracting of qualified people to occupy vacant positions on merit.

- Motivation: the drive to perform, as influenced by the workers' perception of the adequacy of the reward system, such as competitive pay, in relationship to inflation, private sector pay etc.

- Mandatory training and retraining is the planned effort by government to improve staff knowledge and skills of job-related competencies that will improve job performances.

- Decent pension is an adequate retirement fund that is able to keep body and soul together after leaving active working life.

- Propertylessness is seeing the civil service as a means of serving the people and not for the acquisition of material goods or possession 
- Political neutrality to be politically unbiased or impartial and to give advice to the politicians that will lead to the general good of all the stakeholders

- Security of tenure or renewable contract is employment without fear of arbitrary dismissal.

The above features can only be established or sustained in the civil service by a leader who can enforce discipline, rules and regulation; a leader who has a reservoir of historical knowledge and a realistic assessment of the civil service's institutional capacity; a leader with a strong vision and mission for the improvement of the civil service and the society. This leader must have the ability to lead and inspire staff through hard work, brilliance and moral rectitude. The research looked at how successive executive Governors of Lagos State have been able to exert their leadership qualities on these attributes of institutional capacity and ultimately affect the civil service performance.

Institutional capacity also denotes all the non-human assets such as infrastructure and facilities including the work environment, office supplies (papers, photocopying machines etc), Internet and computer and administrative support. This also included decent working environment, and physical infrastructure including power supply, communications, equipment and stationery. Existing ministries and departments are also included in this definition.

\section{Public policy}

Anderson (1975: 3) in his classic definition of policy refers to it as "a purposive course of action followed by an actor or set of actors in dealing with a problem or matter of concern". However, public policy is directed at the population or part of it in order to solve a particular problem or try to reduce or curtail it. The policy process usually divides into three phases as follows, policy formulation, policy implementation and policy evaluation. This process, especially the implementation phase is usually flawed due to political struggle (Grindle, 1981), and lack of financial and human resources (Rondinelli, 1981). For public policies implementation, the performances depend on institutional capacity. Hence, the research sought to determine if the Lagos State Civil Service has the capacity (competent staff, managerial support, office supplies, financial resources, etc.) to make appropriate policy formulation. This is coupled with its ability to effectively implement polices and to provide a reasonable level of public service deliveries to the populace in some social and physical areas like Education, Health, Food, Housing, Security, Roads, Transport, Water, Waste Disposal, Drainage, Employment, Beautification, Rural Development.

\section{Public service delivery}

Public service delivery is the provision of social and physical facilities that help the physical well-being of citizens and contribute to the economic resources. These services are usually those that the private sector does not want to provide or those that people cannot afford at the given market value of such services or products. The legitimacy of the government is therefore premised on the capacity of such governments to provide these services through effective taxation. The effectiveness of public service deliveries is the foundation of citizens' trust for the government to govern them. According to Ostrom, (1991) some of the characteristics of public service or goods include:

- Relatively difficult to measure quantity and quality;

- Consumed jointly and simultaneously by many people;

- Difficult to exclude someone who does not pay;

- Generally no individual choice to consume or not;

- Generally little or no individual choice of kind and quality of goods; 
- Payment for goods not closely related to demand or consumption, and

- Allocation decisions are made primarily by political processes.

The research therefore studies the capacity of the various governments to provide public service deliveries to the citizenry.

\section{Public service performance}

The definition of performance is always problematic and challenging because it is value-laden and this ultimately makes output difficult to measure. The concept of public service performance has been an issue of interest to the populace, politicians, civil servants and other stakeholders. Stakeholders evaluate public service performance according to the ways its services affect their lives in terms of education of children, protection of lives and properties, maintenance and keeping of clean streets, provision of clean and portable water, and so on. However, accurate measurement of the public service has always been difficult because of the nature of its products are services that are hard to measure. This ultimately leads to a lack of accurate data to evaluate the performance of the public service. Secondly, the assessment of these services by the end users is usually subjective. Hence, the research uses both objective and subjective performance measurement in this work. Subjective measurements are the perceptions of the workers to service delivery as collected through interviews and questionnaires. Objective measurement is in terms of objectives and goals, and the actual achievements of certain Ministries

Public service performance is measured through individual, group or organizational levels. The research studied the performance of the Lagos State Civil Service at the organizational level, because at the individual level the Annual Performance Evaluation Report (APER) is used for individual promotion and career advancement rather than for the evaluation of ministerial performance. Group level productivity is rated according to the performance of the group or sub-unit in the organization. However, organization-oriented performance is usually linked with the middle-level and top management cadre in the organization, as these are the ones whose loyalty to the system is at stake. They are more committed to the organization and they have fewer predispositions to quit. The performance of this group of workers, especially the top management cadre, is crucial to this research as they are the staff that is responsible for policy-making and implementation of the numerous government programmes. They play a specific role in the implementation of service delivery to the citizenry. This higher echelon is also responsible for civil service governance and therefore has a major role to play in the performance of the civil service. The research therefore assessed the performance of the civil service from an organizationally oriented perspective.

\section{Civil service reforms}

Civil service reforms are attempts to correct the problems and strengthen civil service capacity through professionalism, accountability and transparency. Nigeria has been involved in a series of civil service reforms for the improvement of government performance. Since the creation of Nigeria as an independent entity, 13 civil service reforms have taken place. According to Balogun (2003), many countries in sub-Saharan Africa have been involved in three major reform programmes; the first being the broad re-evaluation of the civil service's organisation structure, management practice, and incentive system and was embarked upon during the sixties and seventies. The second sets of reforms began in the late seventies through to the eighties with the execution of structural adjustment programmes. There was also the implementation of a mixture of "home-grown" institutional reforms during the late 1980s. The research looks at the roles of leadership both political and administrative on civil service reforms and their effects on performance of the Lagos State Civil Service. 


\subsection{Sampling and Data Collection}

In order to achieve an empirical study, the researcher employed a multi-level case study approach by administering questionnaires as well as interviews and focus group discussions. In order to emphasize the statistical relationship between the dependent variable (performance of the civil service) and explanatory factors, a quantitative analysis of the data was performed. Secondary data were also collected and quantitatively analyzed with descriptive statistics. This phase of the research was divided into six major segments; (i) overview of research population (ii) interviews with present and past civilian and military Governors (iii) development of questionnaires and pilot study, (iv) administration of questionnaires (v) interviews with the informants, (vi) collection of secondary data.

The fieldwork for the research was conducted from July-December 2003 at the Lagos State Civil Service Secretariat, Alausa, Ikeja. The first stage of the research was to identify the research population. The three major groups identified for the study are as follows, (i) Past and present military and civilian Governors, (ii) informants, (iii) staff.

\section{In-Depth Interviews with Past and Present Military and Civilian Governors}

The past and present military and civilian Governors are major actors in the performance of the Lagos State Civil Service. Their perceptions of the problems, and the formulation and implementation of their policies, are major factors that influence the performance of the Lagos State Civil Service. Twelve Governors both military and civilian had ruled in Lagos State between 1967-2005. In view of the peculiarity of this group, the researcher adopted a purposeful sampling method (Patton 1990, p.169). These Chief Executives of Lagos State are in good positions to illuminate on the research questions because of the major roles they played in the events that occurred in Lagos State.

The researcher held open-ended and focused interviews with these Governors (Appendix 1). Open-ended interviews provide personal perceptions and insights into what respondents considered to affect the performance of the Lagos State Civil Service. Interviewees were encouraged to make their own observations of the situation. The interview was partially based on predetermined questions. The nature of the questions made the respondents to relate their experiences freely. The use of open-ended formal interviews supported by a survey questionnaire gives the study a medium to high level of reality.

This section of the study was very interactive and descriptive, with the researcher conducting face-to-face interviews with the Governors. The structured technique using openended questions elicited details on some of the reasons behind some of their decisions. One of the issues they talked about was how they did not anticipate the magnitude of the problems encountered upon their assumption of office although those who had been Governors elsewhere said that they knew about the peculiarities of Lagos State in terms of its diverse culture and volatile politics. On the element of trust between them and the populace, many of the military Governors said that the researcher should appreciate the fact that their posting to Lagos State was perceived as any other assignment. However, they said that they tried to comply with the promises they made to the populace at their maiden speeches. All the Governors were unwavering that the Lagos State Civil Service has the institutional capacity to implement government policies. If this is the case, then, what is the problem?

This aspect of the research was the most interesting and very hectic. The first assignment was to find the respondents current residences. Although the Office of the Chief of Staff of the Lagos State Civil Service was very helpful in this regard, many desired respondents had more than one address and some lived outside of Lagos. As well, some of the addresses were only for official contact and the researcher needed a place for informal personal interaction with them. Further complicating matters was the timing of the research. By the time the 
study started in July, many sought after respondents were outside the country on vacation. The researcher now became a detective trying to find their whereabouts and their personal phone numbers. In the course of this, travels to places outside of Lagos, such as Abuja and Epe were necessary. Following this, the researcher had to make it past the Personal Assistants who are usually referred to as gatekeepers (Saunders et al., 2000). Many Personal Assistants tried to make their bosses inaccessible in view of the sensitivity of the topic. However, the researcher was able to get to some of these Governors by bypassing these "gatekeepers".

Twelve Governors both military and civilian had ruled in Lagos State. Table 1.6 lists the military and civilian Governors and their names are given in appendix IV. Of these twelve, only three are civilian Governors from the inception of the state. Two of the military Governors are dead now. One died in September 2003 in London, while the researcher was still trying to contact him for an interview. Out of the remaining ten, the researcher was able to interview nine. The one Governor not interviewed is currently the Governor of another state. The researcher made several appointments to meet him, only to be informed by his Personal Assistant at the last moment that the Governor would not be able to make it. The interviews with the Governors were tape-recorded and hand-written, this helped to give the interview some credibility. As the interviews were in English, there was no need for translation.

Table 1.6: Lagos State: Military and Civilian Governors 1967-2005

\begin{tabular}{|l|l|l|l|}
\hline S/N & Acronyms & Military/Civilian & Dates \\
\hline 1. & GVM1 & Military & $1967-1975$ \\
\hline 2. & GVM2 (deceased) & Military & $1975-1977$ \\
\hline 3. & GVM3 & Military & $1977-1978$ \\
\hline 4. & GVM4 & Military & $1978-1979$ \\
\hline 5. & GVC5 & Civilian & $1979-1983$ \\
\hline 6. & GVM6 (deceased) & Military & $1984-1986$ \\
\hline 7. & GVM7 & Military & $1986-1988$ \\
\hline 8. & GVM8 & Military & $1988-1991$ \\
\hline 9. & GVC9 & Civilian & $1991-1993$ \\
\hline 10. & GVM10 & Military & $1993-1996$ \\
\hline 11. & GVM11 & Military & $1996-1999$ \\
\hline 12 & GVC12 & Civilian & $1999-2005$ \\
\hline
\end{tabular}

Note: GVM connotes military Governors, whilst GVC is for civilian Governors.

\section{Interviews with Informants}

The researcher understood that the study's innovative approach would be challenging, as experience and knowledge of the system are essential to gain understanding. It was therefore pertinent to seek the assistance of people who are knowledgeable about the workings of the civil service generally and especially of the higher civil service at different periods. For the purpose of this study, we referred to them as "informants". These experts helped in the identification of important issues and gave their views and opinions on such issues. Their insights into the workings of the civil service and the knowledge gained from the literature review acted as a base for the formulation of our questions for both the interviews and the questionnaires.

The first task was to identify these people. Like the Governors, a purposeful sampling method was used for them or what LeCompte and Preissle (1993, p. 69) refer to as criterion- 
based selection. We located both retired and present staff that had been in the system from the $70 \mathrm{~s}-80 \mathrm{~s}$. Some of the criteria used to pick these informants include:

- Ability to give information on governance and bureaucratic set-up of government;

- Ability to express their views and opinions on such issues;

- Had worked in policy formulation and implementation Ministries and Departments like the Governors office, Office of the Head of Service, Establishment, Civil Service Commission, Plans Programmes and Budget Bureau (now Economic Planning), Cabinet Office, Ministry of Environment, etc for considerable period of time, and

- Accessibility.

We identified and interviewed ten people who met the criteria. In view of the sensitivity of this research, the informants' anonymity for those who are still in the service of the state government is of great importance. However, they fall into four general categories and the following acronyms were used for them:

- Retired Secretary to the State Government (RSSG) - 1

- Retired Head of Service (HOS) - 1

- Retired Permanent Secretary (RPS) - 2

- Serving Permanent Secretary (PSS) - 4

- Serving Directors (DS) - 2

The interviews with the informants started in July 2003, and ran for almost the whole period of the fieldwork as the researcher constantly interacted with them. Discussions varied from global issues, partisan politics to personal issues, and so on. Furthermore, they were also asked the same structured questions. The questions gathered information on their backgrounds and the various ministries that they had worked in, as well as asking them to compare the civil service they joined with the present situation. They were to indicate government policies that affected positively or negatively the institutional capacities of the Lagos State Civil Service. The questions asked them to indicate what factors were responsible for negative or positive developments in the service and to discuss their views of a visionary leader. Their opinions about issues and actors that affected the evolution of the Lagos State Civil Service were also asked, as well as the role of education and training. The content of the interviews is attached as Appendix II.

One thing was common to both the retired and current staff, a passion for the civil service. While those already retired spoke about it with nostalgia, those present bemoaned the valuable opportunities that had been lost through inconsistencies in government policies. The researcher tried to get the informants to focus on what happened, how and why the systems of operation of the Lagos State Civil Service evolved as it did. According to them, the Lagos State Civil Service started on a very modest scale with only seven ministries at its inception. The limited size allowed nearly everybody to know each other and the esprit de corps was very high. The nucleus of the government was staff recruited or seconded from the Federal and Western region ministries. The workforce was knowledgeable and very skilful and not surprisingly, contributing to the positive perception of Nigeria's Civil Service within the Commonwealth. The civil servants were encouraged to be apolitical and had every reason to be so. Furthermore, the scope of operation of the government was relatively small and manageable. With reference to other newly created states in Nigeria, Lagos State was and still is the most economically buoyant boasting over $50 \%$ of the country's large-scale and financial institutions.

Certain issues were common in the contributions of all the informants, most of which were incorporated in the questionnaire that was developed subsequently. The issues are as follows:

- How has the political leadership influenced the civil service?

- How has the political leadership influenced the administrative leadership? 
- Who determines the quality of the civil service?

- Does the Lagos State Government have the institutional capacity to formulate and implement policies?

- Does the government have adequate resources to finance all levels of public services to its populace?

- Who are the actors that contributed to the development of the Lagos State Civil Service?

- What are the effects of the Federal Government macroeconomic policy of Structural Adjustment Programme and its effect on state governments?

- How have the adopted strategies of the various reforms affected the assigned tasks and goals of the civil service?

- Is there a decline in the civil service? If there is, in what respect, human, institutional, organizational, or infrastructural or others?

- At what point would you say that the decline became evident? What were the relevant conditions under which this happened?

\section{Staff}

The study sample for the research was taken from the Lagos State Civil Service. Lagos State is the second largest employer of formal labour after the Federal Government. In its employment it has people from virtually all the 36 States in the country except Bauchi, Ebonyi, Jigawa, Niger, Taraba and Zamfara and is a good representation of all the country's ethnic groups. In 2002, the total workforce of the Lagos State Public Service was 51,221 ${ }^{19}$, while the civil service constitutes 13,285 or about $25 \%$. The civil service consists of 4,076 junior staff (grade level 01-06), 7,970 mid-level staff (grade level 07-12), and 1,151 senior management staff (grade level 13 and above), (Lagos State Public service Manpower Statistics, 2002).

To make the study meaningful, the researcher adopted a purposive sampling method. Attempt was made to incorporate staff that could make meaningful contributions to the research since the study cuts across a period of more than 30 years. The staff needed a substantial knowledge of the system in order to do a comparative assessment. Two hundred staff members from the senior management and directorate levels were requested to complete the questionnaires.

\section{Development of questionnaires and pilot survey}

Following the informants' observations, the initial questionnaire was modified. The initial questionnaire had many closed-ended questions; more open-ended questions were added in order to give the respondents their say on the issues. Although this made codification of the data more complex, it provided a more objective view to the respondents' positions on certain issues. The questionnaire model was divided into five sections as follows:

- Personal information;

- Views on quality of the Civil service;

- Views on determinants of decline;

- Views on various Civil service reforms, and

- Leadership perspectives.

The researcher conducted a pilot survey following the development of the questionnaire model. The initial questionnaire model was administered to a representative sample of the target group in order to detect problems of question wording, variance, validity, format and rela-

\footnotetext{
${ }^{19} 88$ officers did not give sufficient information so they could not be included in the analysis.
} 
tionship. This helped to detect and correct defects in the questionnaire model and its administration, before embarking on the final survey.

During the pilot survey, the following problems were encountered:

- Respondents did not want to answer the personal information section. Therefore, the personal information was removed from section 1 to section 5 .

- Due to many open-ended questions incorporated into the questionnaires, many questions were unanswered.

- Respondents complained that the questionnaire was too long.

- Respondents complained that some of the questions were too direct although majority subsequently answered them.

- Staff were initially reluctant to fill the questionnaire because they feel that they were assessing their bosses.

- Some were not sure who would eventually get hold of the questionnaires and that they may be victimized if they assess the present administration negatively.

- The question on social, physical and infrastructural needs was rephrased as it was very complex and many people did not complete it.

- Many of the people did not fill the questionnaires very quickly and kept on telling the researcher to come back with a promise that they would finish answering them later. This went on for several days.

\section{Administration of questionnaire}

Based on the knowledge gained from the pilot survey, the final questionnaire was developed (Appendix III). This was finalized after a series of interviews with the informants, literature reviews and informal focal group discussions with colleagues. The informal method was employed, to encourage open expression on the issues discussed. During the administration of the final questionnaires, the researcher used the help of the Director of Finance and Administration (DFA). The researcher's experience as a DFA prior to embarking on the PhD programme, provided an esprit de corps that helped to achieve the near impossible. Since it was a personal and not official assignment, a lot of goodwill came into play. Also, having been a superior officer or colleague, many filled it out of respect for the researcher. The researcher's various assignments in the Training Department and the Civil service Commission, allowed her to have met many of the staff at various times during the course of their careers.

Many of the DFAs volunteered to help in the administration of the questionnaires, while some assigned junior officers to follow up with the collection. The administration of the questionnaires started in early August 2003, and ended October 2003. Of the 200 questionnaires distributed, 151 were recovered representing a response rate of $75 \%$, an excellent recovery rate given the nature and sensitivity of the research.

The researcher informed the DFAs of her experiences during the pilot survey, especially respondents' concerns about the nature of the research. The rationale for the research was given and they were informed that the answers would be treated responsibly and with discretion. Respondents were informed that the analysis of the questionnaires would not be carried out at the Lagos State Civil Service Secretariat and it was agreed that completing the personal information was a matter of personal choice. Many respondents felt that even without mentioning their names their identity could still be traced through the number of ministries they have worked in and their grade levels.

By 2003 the Lagos State Civil Service had 43 Ministries and Departments in three main categories: Economic, Social, and Administrative. Questionnaires were administered to 22 Ministries with each category represented as follows: 


\section{ECONOMIC}

- Commerce and Industry (5),

- Lands Bureau (10),

- Economic Planning and Budget (10),

- Board of Internal Revenue (10),

- State Treasury Office (10),

SOCIAL

- Health (10),

- Education (10),

- Justice (5),

- Works (10),

- Agriculture and Co-operatives (10),

- Information and Strategy (10),

- Political and Legislative Matters Bureau (10),

- Home Affairs (10),

- Environment (10),

- Local Government and Chieftaincy Affairs (5),

- Lagos State Environmental Protection Agency (10),

- Youth Sports and Social Development (10)

ADMINISTRATIVE

- Governor's Office (10),

- Office of the Head of Service (10),

- Civil service Commission (5),

- Establishment and Training (10),

- House of Assembly (10).

Each Ministry or Department was given between 5-10 questionnaires depending on the staff strength.

\section{Secondary data collection}

The study analyzed existing data in order to answer some of the research questions. Public records provided information on past and present government policies, practices and achievements. Most specifically circulars, memoranda, civil service rules and regulations, reports were critically examined in order to assess the progress or otherwise of the civil service. Both qualitative and quantitative analysis of the data was performed. This information complemented that collected through the interviews and questionnaires and helped to give the research findings some rigour.

The research looked into one case of government's intervention, which could be studied over a period of time in terms of quality and effectiveness of such interventions in the education sector. The researcher tried to find out whether the Lagos State Government has the institutional capacity to formulate and implement its policies. If yes, how successful are government's intervention in this area of public service. If not, what are the inhibiting factors? How can the effectiveness of government intervention be enhanced and its short coming eliminated?

\subsection{Data Analysis}

The interviews with the Governors were very important for the credibility of this study so it was audio-taped and hand-written. After each interview, the researcher tried to listen to the 
interview tapes and examine this with the interview scripts. Interview for each Governor was entered into the computer using Microsoft word. This made comparison easier as the various thoughts of the Governors for each question asked was categorised, and used accordingly in answering the various questions put to them. The data file made for easy analysis as quotations could be easily retrieved to appreciate events, challenges, successes, and so on. The coding of the informants interviews almost followed the same pattern of categorisation.

In view of the multi-method approach that was used in the data collection, it was pertinent to use both quantitative and qualitative data analysis. A survey was conducted through the administration of questionnaires, to determine the views of respondents' on leadership qualities, civil service reforms, and so on. Thereafter, the data were categorized and coded and a number was assigned for each category. For example, leadership qualities, which by definition is meant to be a continuous variable, has to be quantified, so a non-Parametric tests of statistical significance were used. Such variables were given values and the use of Likert type scale was employed, where $5=$ "very important" and $1=$ "don't know". These were entered as numerical variables into the data file.

Our research focus generated some simple descriptive statistics about the evolution of the Lagos State Civil Service. For example, simple perception questions that could easily be quantified were used as our dependent variable such as:

"Are there enough managerial and technical skills to effectively carry out social service deliveries to the general public?

Yes

$$
\text { No }
$$

\subsection{Measurement of Variables}

The issues of validity and reliability are of great importance in case study research to assure replicability. In other words, any researcher interested in studying similar issues with the same focus should be able to arrive at matching results (Yin, 1994; Gummesson, 2000). For most qualitative research, "validity threats" must be ruled out through "evidence collected" (Maxwell 1996 p. 88). In order to increase the construct validity of this study, the researcher audiotaped the interviews with the Governors, which is one of the most important sources of information for this work.

One of the criticisms of the case study approach is that the researcher uses "subjective" judgments and they do not have an adequate amount of operational measures to collect data (Yin, 1994,). According to Maxwell (1996), "lack of careful assessment of the design decisions and data analysis can lead to a flawed study". However, the researcher was aware that personal preconception might prejudice the validity of the conclusions. But at the same time, the experiential knowledge about the Lagos State Civil Service can also act as a validity check, as ties to the study could offer important source of insight and facts (Marshall and Rossman 1995). However, in order not to uncritically enforce her ideas on the outcome of the research, therefore the introduction of quantitative component.

\subsection{Structure Of The Thesis}

The study is structured into seven chapters. Chapter two discusses the literature as it affects public service performance in developing countries- the challenge of the new public management. Chapter three discusses public policy and public service performance under issues like leadership role in public policy (continuity and episodic policies, policy legitimization and accountability), institutional capacity and public policy, and the patrimonial disposition of the state and impact on public policy. It also looks at how the quality of public policies affects 
public service performance. Chapter four looks at the role of political leaders in public service performance under the topic, leadership competence on decision-making and problemsolving, and the Lagos State Governors reviewed. Chapter five discusses institutional capacity and public service performance looking at human resources management, finance and economic policies and the organizational structure. Chapter six addresses the issue of whether the civil service reforms in Nigeria have impacted positively or negatively on the institutional capacity and public service performance. Finally, chapter seven gives the overall recommendations and policy implication of the research. 


\section{Approaches to Public Service Performance in Developing Countries- the Challenge of New Public Management}

This chapter provides a selected review of pertinent frameworks by which the public service is studied and its performance appraised. In order to achieve this, this section examines literature on governance, bureaucracy and leadership particularly as it relates to the performance of the public service. It looks at Weber's classic perspective on bureaucracy as it relates to postbureaucracy formulations and in particular New Public Management (NPM); also the relationship of political leadership and the bureaucracy. We pose two questions. First, how effective is the application of the NPM for improving performance in the public service especially in developing countries? Second, what are the challenges that confront NPM in the African countries generally and in the one under focus in this dissertation in particular, and what is the role of the political leaders.

\subsection{From Weberian Bureaucracy to New Public management}

One of the earliest and arguably the most established theory on public service is the Weber's organizational theory on bureaucracy and the concept of the public service as a bureaucratic organization. Weber's formulation advances the notion of strict adherence to a bureaucratic framework with an emphasis on efficiency in the public service (Weber 1947). Recently, there has been a paradigm shift in the study of the public service from a bureaucratic organization to a post-bureaucratic organization. The belief here is that too much adherence to rules and regulations can be counter-productive. What the public service needs is the enforcement of norms of accountability, transparency, and performance. The most popular effort to apply these principles in recent years is the New Public Management movement.

\section{Weberian Bureaucracy}

The subject of public service performance has acquired additional interest for both researchers and administrative practitioners by the end of the 20th century. As government's activities become more complex in the day-to-day running of the societies, efforts to develop strategies to improve the service delivery of governments have also risen. Max Weber believes that his ideas of bureaucracy in government organizations will help to explain why the modern bureaucracy found in industrialized Western countries has helped them achieved maximum performance. He postulates that large-scale, complex organizations need formalized rules and procedures in order to run effectively. The bureaucratic nature of an organization, according to Weber, stems from the fact that it operates under a hierarchy of authorities, emphasises meritocracy and not inherited right or ownership, and that the decision-making process follows a chain of command, amongst other characteristics. According to Weber, the concept of bureaucracy as an organizational theory is the "most rational" and "ideal" solution to the complexities engrained in the operations of "modern organizations.

Accordingly, this type of bureaucracy is referred to as Machine Bureaucracy, in the sense that human beings are expected to perform their own functions as against being allowed 
to use their creative abilities effectively. Emphasis is on the division of labour, rules, and regulations. Weber advocates a system that uses meritocracy in order to eliminate corruption and inefficiency. Table 2.1 shows some salient features of a Meritocracy or Merit system.

Table 2.1: Key Elements of a Meritocracy or Merit System

\begin{tabular}{|c|c|}
\hline Salient Features & Rationale \\
\hline Recruitment and promotion based on merit & Efficient Administration \\
\hline $\begin{array}{l}\text { Competitive pay (ref. To inflation, private sec- } \\
\text { tor pay, or specific job requirements) }\end{array}$ & Attraction and retention of the "best and the brightest" \\
\hline Mandatory training and retraining & Efficient administration and productivity \\
\hline $\begin{array}{l}\text { Decent working environment (space, tools, } \\
\text { supportive infrastructure) }\end{array}$ & as above \\
\hline Decent pension & Fairness, efficient administration, incorruptibility \\
\hline Propertylessness & as above \\
\hline Political neutrality & $\begin{array}{l}\text { Continuity and predictability of Government business, fair- } \\
\text { ness and impartiality to citizens, loyalty to incumbent politi- } \\
\text { cal leadership, smooth leadership succession }\end{array}$ \\
\hline Security of tenure or renewable contract & as above \\
\hline Accountable performance & Fairness and impartiality to all citizens \\
\hline
\end{tabular}

The features imply that recruitment, employment, and promotions are based on qualifications and achievement, internal labour markets and professionalization. It constitutes a career with no arbitrary termination of appointment. The system is impartial, permits no favouritism or nepotism, and promotes unbiased decision-making. The organization of offices is based on the principle of hierarchical structure where authority is invested in the positions within the hierarchy. According to Weber, strict adherence to this bureaucratic framework will lead to effective performance of the Public service. However, many bureaucratic organizations still perform badly. So to what level of adoption of this bureaucratic concept must one achieve to reach the optimal level of performance?

\section{Post-Bureaucracy: an Emerging Organizational Shift}

More recent developments in organizational theories have challenged Weber's bureaucratic model. The term bureaucracy is often used synonymously with inefficiency in organizations due to its connotation of rigid adherence to rules and regulations. The degree of inefficiency depends on the organization's degree of rigidity to rules and formal structuring. Therefore, some organizations are moving away from bureaucratic administrative structures to systems that emphasize interaction, cooperation and collaboration within the system. The pyramidal organizational structure is being flattened. Emphasis is on information sharing and decisionmaking is no longer top to bottom. Barzelay (1992) and Heckscher (1994) are some of the proponents of post-bureaucratic organizations. In his efforts at reorganization, Barzelay makes a comparison between the old bureaucracy and the new post-bureaucratic paradigm as depicted in Table 2.2. 
Table 2.2: Bureaucracy and Post-bureaucracy in Government

\begin{tabular}{l|l|}
\hline Bureaucratic Elements & Post-bureaucratic Element \\
\hline Public interest & Results citizen value \\
\hline Efficiency & Quality and value \\
\hline Administration & Production \\
\hline Control & Winning adherence to norms \\
\hline Specify function, authority, and structure & Identify mission, service, and customers \\
\hline Justify costs & Deliver value \\
\hline Responsibility & Accountability \\
\hline $\begin{array}{l}\text { Follow rules and procedures } \\
\text { Operate administrative systems }\end{array}$ & $\begin{array}{l}\text { Understand and apply norms, solve problems, improve proc- } \\
\text { esses }\end{array}$ \\
\hline $\begin{array}{l}\text { Source: David Jaffee, Organization Theory Tension and Change, (Boston: McGraw-Hill International Editions, } \\
\text { 2001) p. 168, Table 7-2. As adapted from Table } 3 \text { in Michael Barzelay (1992), Breaking through Bureaucracy } \\
\text { (Berkeley: University of California Press), p.118 }\end{array}$
\end{tabular}

The issue of interest in a post-bureaucratic structure is a shift away from "public interest" to "results citizen value". Public service operations should focus on customers" satisfaction. The standards of service delivery should be in line with the citizens' expectations, in terms of efficiency, reliability, credibility and timeliness. Original efforts should meet or exceed customers' expectations. The measure of success is in the customers' satisfaction with the service. Compliance to rules and regulations that slow down the operations of the government should be de-emphasized. Institutional machinery should solve problems and improve the administrative process. There must be transparency in the decision-making process in order to guard against the abuse of power. Transparency also enhances the credibility of the public service delivery.

In order to give a competitive and quality service, the focus of the public service should no longer be on administration, but on production. Structural improvement of the public service is through the elimination of duplication and obsolete functions of the public service with emphasis on its right size. The emphasis should be from justifying costs of service delivery to expansion of customers' choice and provision of incentives to hard working staff. The result of service delivery must be measurable and analysable. Post-bureaucracy is an alternative to Weberian bureaucracy attempting to move away from the bureaucratic concept of public service in order to improve performance of government. The most recent segment of this wave is the New Public Management movement.

\section{New Public Management (NPM) Movement}

With the recent globalisation of the economy, technological innovation, and democratisation and emphasis on good governance, many countries are faced with challenges in their public sector that need immediate solutions that are transformational in nature. Governments want organizational restructuring as an attempt to raise their performance by improving the quality of service delivery. Civil service reform was called by many names such as new public management, administrative reforms, bureau-shaping, post-modernism, and so on. It is an attempt by various governments to find a panacea to the ills in their public management. The issues of efficiency and effectiveness in the performance of the public service as well as good governance have become a major concern of many developed and developing countries. 
Different political, economic, and socio-cultural factors in both the developed and less developed countries led to the "reinventing government" movements. For example, the United States, Britain, New Zealand, Australia and countries in East Asia, like Singapore, Malaysia have endorsed New Public Management as a means to improve their civil service. Dunleavy and Hood (1994) note the similarities in the civil service reforms especially amongst the industrialized English-speaking countries. The less developed countries in Latin America and Africa, at the instance of international lending organizations like the World Bank, International Monetary Funds, and other donor agencies, followed the guiding principles of NPM as "endorsed" by such organizations, in order to improve the performance of their civil service.

New Public Management came up with different concepts for performance, and different models have been developed over the years. Hood (1991) lays emphasis on performance as the concept for reform initiatives. Accountability and efficiency must come through measures including the reduction of public sector expenditure; improvement in resource use through labour discipline; flexibility in decision making; competition in the public sector through decentralization and disaggregation, and emphasis on result and not procedure.

Pollitt (1996) believes that the success of NPM should be evaluated against the following eight elements.

- Cost cutting, capping budgets and seeking greater transparency in resource allocation.

- Disaggregating traditional bureaucratic organizations into separate agencies ('Executive agencies', 'Government business enterprises', responsibility centers', state-owned enterprises', etc.) often related to the parent by a contract or quasi-contract (performance agreement', 'framework document', etc.)

- Separating purchaser and provider, i.e. distinguishing the functions of providing public services from those of purchasing them

- Introducing market and quasi-market-type mechanisms

- Decentralization of management authority within public agencies ('flatter hierarchies')

- Introducing Performance Management: staff are now required to work with performance targets, indicators and output objectives

- New personnel policies that shift the basis of public employment from permanency and standard national pay and conditions towards term contracts, performance-related pay (PRP) and local determination of pay and conditions

- Increasing emphasis on service quality, through standard settings and a new focus on 'customer responsiveness'.

Jones and Thompson (1999) emphasize the importance of information technology in reshaping and reinventing the private and public sectors. They interpret NPM as the five Rs' (1) restructuring or downsizing to focus on core competences; (2) work process re-engineering; (3) radical organization reinvention; (4) realignment by introducing activity-based costing and responsibility budgeting, and (5) rethinking- by reconceptualizing public sector bureaucracies as learning organizations.

Ferlie et al. (1996) conceptualise all the models of NPM into four categories as follows: (1) efficiency model; (2) downsizing and decentralization model; (3) management of change model, and (4) Public service orientation to change model. However, in his own contribution, Peters, (1996) reframes the key problems confronting public administration as structure, management, policy process and key players, and how they interact for the common goal of the public. Finally, other observers comment that the main concerns of NPM are accountability, transparency and performance (Polidano 1999; Larbi 1998).

In his contribution, Peters (1996) places the old public discipline into 'chestnuts' and compares its salient beliefs with that of the New Public Management as depicted in Table 2.3 below. The NPM advocates political and accountable management that discourages rent seek- 
ing. Service delivery should be operated as a market or quasi-market-type apparatus that is based on competition with the superior market taking the lead. Emphasis is therefore based on contract and not rules.

Table 2.3: Peters: Old Public Administration 'Chestnuts' Compared with NPM Doctrines

\begin{tabular}{l|l|}
\hline Old Public Administration & New Public Management \\
\hline $\begin{array}{l}\text { Apolitical Civil service } \\
\text { Hierarchy and Rules }\end{array}$ & $\begin{array}{l}\text { Political and Accountable Management } \\
\text { Markets are superior to markets, emphasis on contracts, } \\
\text { not rules }\end{array}$ \\
\hline Permanence and Stability & Contractual Management \\
\hline $\begin{array}{l}\text { Institutionalised Civil service } \\
\text { Internal Regulation }\end{array}$ & $\begin{array}{l}\text { Only small policy and strategic centre required } \\
\text { privatised or decentralised }\end{array}$ \\
\hline $\begin{array}{l}\text { Equality of Outcome } \\
\text { Source: As extracted from Peters (1996) by Dele Olowu in New Public Management: An African Reform Para- } \\
\text { digm? 2002 }\end{array}$ & \begin{tabular}{l} 
Differential outcomes \\
\hline
\end{tabular}
\end{tabular}

According to observers of public service development, the old public administration 'chestnuts' took hundreds of years to become institutionalised in the developed countries (Olowu, 2002). In his study of institutional development in the now developed countries (NDCs), Chang, (2002) observes that these countries developed through evolutionary processes between early nineteenth and twentieth centuries. The civil service in countries like Britain, France, Italy, Prussia, Spain, or the U.S.A., were plagued with sales of public offices, nepotism, godfathership, and allocation of public offices to party loyalists (spoils system). The evident results were lack of meritocracy or professionalism in the developmental stages of public institutions of these countries. Many of these countries have gone through series of bureaucratic reforms in order to reach the stage of modernization they are at now.

Unlike earlier reforms, especially those in Africa that are targeted at national development, current reforms are aimed at cost reduction and refocusing of public sector activities on service delivery and the economy at large (Therkildsen, 2001). These reform efforts result from pressure by financial institutions and donor agencies, usually in the face of structural adjustment programmes, internal pressures for change in the wake of political pluralism or emulation of other countries (Mutahaba et al., 1993).

In the developed countries, the NPM was an effort to improve government service delivery to the citizenry because of the expectations of the people. In many developing countries of Latin America and Africa, the NPM was a paradigm shift from autocracy to democracy in the dawn of political pluralism. It is believed that democratic governance will transform into a better governance that will lead to "public policies that are technically efficient and effective and also responsive to the needs of large sections of the citizenry, if not the whole public" (Olowu, 2002:3).

\section{Governance}

Like many other concepts, consensus is lacking as to the definition of governance because of the different ways it has been applied. For example, Rhodes, (1996) identifies at least six governance concepts as follows:

- Governance as the minimal state;

- Governance as corporate governance;

- Governance as the new public management; 
- Governance as "good governance";

- Governance as a socio-cybernetic system, and

- Governance as self-organizing.

Governance in the NPM strongly advocates a minimal state, which emphasizes a scaled-down role for government in economic activities. The role of governance is however beyond that of government ${ }^{20}$, because it incorporates more complex and diverse actors and institutions. The study of governance therefore involves several issues including government, political system, socio-political concerns, private sector, civil society, research centres, and the relationship between these institutions and their role towards collective actions.

Two major schools of thought are currently gaining ground amongst academics and policy-makers as to the definition of governance. The first definition, mainly used by international organizations like the World Bank and the United Nations organizations, define governance as the manner in which power is put into use in the organization of a country's economic and social development (United Nations Development Programme, 1997). According to the World Bank (1999:1), governance is defined as the "traditions and institutions by which the authority in a country is exercised. This includes (1) the process by which governments are selected, monitored and replaced, (2) the capacity of the government to effectively formulate and implement sound policies, and (3) the respect of citizens and the state for the institutions that govern economic and social interactions among them". There are many similarities in the above definitions that relate to major aspects of liberal democracy, although Schacter, (2000) has criticised the World Bank that its use of governance is limited to promoting economic development, instead of human rights or democracy.

The second group advances a "partnership approach" to governance that believes the state and non state organizations manage the public through authority sharing. The emphasis here is on private and public sector cooperation through joint actions or arrangements tried to achieve a common goal. This "socio-political" approach sees governance from the "perspective of a society as a whole" where the state and the civil society interact. Gijsbers (2001) believes that the "idea of governance is used to present new ideas of public sector management, using models that emphasize the involvement of partners from beyond the public sector". The proponents of NPM are more inclined to this second approach.

\subsection{Is NPM a Solution for African Economies?}

The question remains, how appropriate is the application of New Public Management to African economies. Advocates of NPM like Hughes, (1998) think that a new era in public administration evolved with the advent of NPM. He believes that some machineries of NPM such as public choice or agency theory will provide explanation for some of the economic and fiscal crises of welfare state. According to Hughes, Western countries right wing politicians believe that the state should become minimal in view of its huge scope, size and methods.

The OECD public sector management sector (PUMA) has also reported some success stories in some OECD countries that have applied the NPM strategies in their public sector reforms, albeit with wide variations, over the past twenty years. According to Halligan (2001), significant changes have been associated with the application of NPM in these countries. Furthermore, international organizations and major financial institutions regard New Zealand as a success story in the implementation of the New Public Management in its public sector. The

\footnotetext{
${ }^{20}$ Govert Gijsbers (2001) defines governance as the "- way in which organizations, inter-organizational networks and systems are designed, steered and directed towards performance"
} 
New Zealand Government has introduced several innovative reforms that are tagged "Government by Contract".

According to Schick, (1998:2) "Virtually every element of the reform has been designed to establish or strengthen contract-like relationships between the government and the ministers as purchasers of goods and services, and the departments and other entities as suppliers". Existing bureaucratic organizations are disaggregated into separate agencies relating to the parent by contract. The relationship is based upon performance agreement. This is what Davis et al., (1997) refer to as "The New Contractualism". New Zealand, however, developed this model on a formal public service, based on the Old Public Discipline. Some developed countries like Iceland and newly developing countries like Singapore have selectively adopted some of the contractualism reforms initiatives. United Kingdom and Sweden did not take on the hard-line, but rather the managerial aspect of the reforms that suited their needs.

Even then, some critics like Boston, (2000) still question the success of the impact on the system in the developed countries. Further, these critics believe that public and private sector principles are different. For example, Kelly, (1998) queries the assumption that contractual production is more efficient than bureaucratic production, as there are no empirical evidence to support this. Terry, (1998) also believes that public sector democratic values of citizenry representation and participation, fair dealing and impartiality may be at variance to entrepreneurial model of the public sector that is self-serving and rational.

However, in spite of political pluralism and the introduction of public administration reforms largely in the 1980s that were supposed to be founded on accountability, transparency and performance, by the millenium, Africa continues to be the most economically disadvantaged continent in the world. The African Development Bank (2001), records a high level of the trade deficit, indebtedness, poverty and economic instability compounded by diseases and social conflicts. Proponents of public reforms in the form of NPM are now concluding that the results have not been satisfactory in view of their apparent failures.

The MDGD-Civil Service Reform paper (1998) believes that the success of any reforms, especially in the developing countries, must be essentially indigenous, although the exercise might have been a result of external pressures. Therefore, sensitivity to the existing conditions in the country is stressed. Assumptions dictate that the accomplishments of such reforms in these countries must have the following preconditions:

- The establishment of a nation-wide political system;

- The establishment of a stable, workable constitutional system;

- A viable economic system;

- An enlightened, unified elite capable of guiding orderly change, and

- An electorate sufficiently aware of the nature of administration and its rights and responsibilities vis-à-vis its civil servants.

According to Wescott, (1999), the African Governments need a strategic framework for the improvement of their public service's performance. To him, donor agencies should appreciate the political sensitivity and limited administrative capacities of these countries and should accordingly, help to facilitate the latter. He believes that linking reforms to structural adjustment programmes not only limit the effectiveness of the aid donors, but also reduces the empowerment the affected government needs to design and carry out the necessary administrative reforms. Financial institutions and donor agencies should move a step further than strictly adopting the guiding principles endorsed by Special Programme of Assistance for civil service reforms in Africa. For better results, attention is necessary for economic reform and adjustment, leadership and commitment, governance, programme design, sequencing and timeframe, ministerial restructuring and decentralization, downsizing, pay and incentives, performance management, capacity building, and finally, implementation, monitoring and evaluation. Reforms take time and adequate time is required for effective implementation. 
Olowu (1999) emphasizes the need to redesign African Civil Service Reforms and he attributes lack of success to "faulty diagnosis and prognosis". The civil service of the 1980s and 1990s were the products of the Structural Adjustment Programme that emphasized the reduction of the state in development and reduction in the total expenditure of the civil service. $\mathrm{He}$ identifies two broad elements of civil service reforms as, 'core' and 'non-core' elements. Core elements are organizational restructuring and budgetary and financial reforms. Although very popular in the reforms of many countries, their impacts have been minimal. Non-core reform elements include strengthening the capacity of policy-making institutions, political responsiveness of top civil servants and capacity-building in the civil service. The applications of these elements have produced some 'successes' in certain countries, however Olowu reiterates that the major problems that confront the civil service relate largely to human resources management. These include the poorly organized merit system, a weak system of accountability, excessive politicisation and centralization, and inadequate resources. He believes that an effective civil service reform in Africa would focus on re-asserting meritocracy, improving accountability, decentralizing operations and structures, mobilizing resources for civil service reforms, and improving information base.

Hood (1995) analyses the impact of the NPM in terms of motive and opportunity. However, tactical efforts in the design and implementation of civil service reforms are of great importance according to Polidano, (2001). These include three important issues: the scope of the reform, the role of the donors, and the leadership of the reforms. He observes that the scope of change must be narrow; the role of the aid agencies must be limited; and reform must have firm leadership while allowing the line management some discretion. Furthermore, he notes that reforms will never get past implementation stages without active political leadership backing.

\subsection{Governance and Political Leadership}

Any reform initiative in governance needs unequivocal political leadership support. The influence of political leadership in the bureaucratic structure of organizations, especially the public sector, is becoming of increased importance to policy practitioners. International organizations and financial institutions support that there is a connection between the high level of poverty and corruption in Africa and political misrule and bad governance. The role of political leadership in governance and the introduction of any public service reforms cannot therefore be underestimated. Corkery et al. (1998) opine that, for any reform to have credence it must have "explicit political support" over a length of time. According to Wescott, (1999:7) "African Governments need policy statements on CSR to be endorsed at the highest level of government as a foundation for the development of detailed programmes". Lack of political support will make implementation nearly impossible for the administrative leadership.

The role of leadership and especially political leadership is of great importance to this study. The study of leadership has always been based on axiological assumptions because leadership qualities are value-laden. The study of leadership has been evolutionary from the trait phase (1920s) to the behavioural phase (1950s), to the contingency phase (1970s) to the charisma phase (1980s), and recently to the debate between transformational and. transactional leadership (Avolio and Bass, 1999). Apart from grouping leaders using leadership traits, another way to categorise leadership is through power styles. Bass (1990) distinguishes leadership literature under three broad categories of power styles defining leaders as authoritarian, democratic or laissez-faire.

This study's research paradigm focuses on the power styles of leaders. The analytical review focuses on authoritarian and democratic leadership as they relate to political regimes of their respective governments. Studies in this area cover a range of government leadership 
styles from authoritarian to democratic. The Tannenbaum and Schmidt Continuum of leader behaviour $^{21}$ identifies seven possible leadership behaviours, with each behaviour influenced by the relationship between the leader, follower, and the situation. At one end of the continuum are democratic leaders that allow followers to function and develop within the limits set out by these leaders. At the other end of the continuum are authoritarian leaders that do not allow for followers' input.

The democratic and the authoritarian leaders relate to their followers in "relationshiporiented" or "task-oriented" behaviours, respectively. One of the most important aspects of this situational leadership approach is the source of authority of the leaders, which ultimately influence the level of freedom of the followers and the use of authority by the leader. Democratic leaders give their followers a large amount of freedom, whilst the authoritarian leader or autocratic leader restricts freedom and uses authority to motivate functions. Equally, on the political realm the classical approach believes that authoritarian/autocratic regimes have an "advantage in economic development", although this assumption is being criticised (Minxin Pei 2005).

\section{Leadership Styles}

\section{Authoritarian Leadership}

Leadership styles depend upon the leaders' assumptions about the source of their authority and power (Hersey et al., 1993), and how they choose to engage that authority and power. In the political realm, authoritarian leaders are usually dictators or military rulers, neither elected nor voted in by the people. According to (Otobo, 1999:293) "The legitimacy of the military regime is derived from its monopoly on coercive powers-ruling from the "barrel of the gun". In Nigeria, the Military Executive has had many names such as the Military Council, the Supreme Military Council, the Armed Forces Ruling Council, and Provisional Ruling Council, and has always taken over the powers and authority of the legislature. The judiciary's activities are usually constrained through a promulgation of inhibiting decrees and a disregard for constitutional rights of citizens. As a result, there is no legislative or judiciary monitoring of the military and they feel above the law, or that their word is law.

They are task-oriented, wanting to get the job done through whichever seems the most direct way be it by force, threat or manipulation. They generally do not accept advice from their subordinates because they feel that they cannot be trusted. With this type of authoritarian leadership: "all policies are determined by the leader" (Hersey et al., 1993:118). This is because the assumption of the autocratic leader is that workers are lazy and unreliable (Theory $\mathrm{X})$. Major problems with this type of leadership are the suppression of creativity, the discouragement of innovation, and the failure to develop leadership in its followers. Orders and decrees are passed down and mistakes may result in "critical appraisal or dismissal". In a military regime, this ultimately leads to cronyism amongst the staff, and the workers survive on shifting the responsibility or empire building in order to increase their job security.

Some researchers believe that organizations with authoritarian leadership usually have a higher turnover rate and absenteeism in their organization. On the political realm, authoritarian/autocratic government dictates to the people and the people are compelled to follow. Some argue however, that on the organizational level, autocratic level leadership could be effective in cases where the employees are still new and untrained, or when supervision is seen to be effective only through detailed instruction and orders.

\footnotetext{
${ }^{21}$ The work of Tannenbaum and Schmidt (1958) is one of the major research works on situational approaches to leadership.
} 


\section{Democratic Leadership}

The power base of a democratic leader is different to that of autocratic leader. The democratic leadership style "assumes that the power of leaders is granted by the group they are to lead and that people can be basically self directed and creative at work if properly motivated (Theory Y)" (Hersey et al., 1993:118). This type of leadership is participatory and it encourages workers to be involved in decision-making and problem solving. There is a high element of trust and this leads to cooperation and high morale. Achievements are recognised and encouraged.

On the political realm, the management style of this type of governance is participatory; people participate in the policy making of the country through their representatives in the parliament, House of Assembly, Senate, civic societies, etc., who are appointed, responsible and directly accountable to the people. In a democratic/civilian government, the leader should consider the wishes of the people, and the belief is that public policies will be transparent and open. The leaders are receptive to the people because the people in a free vote elect them. The emphasis should be on the common good of the people. This would ultimately lead to improved economic performance and poverty reduction.

Actually, the above dichotomy between authoritarian and democratic leadership as being representative of military and civilian regimes respectively does not usually exist in this sort of neat categorization. The reality in every situation is far more complex.

Figure 2.1: Combination of Regime Types and Leadership Styles

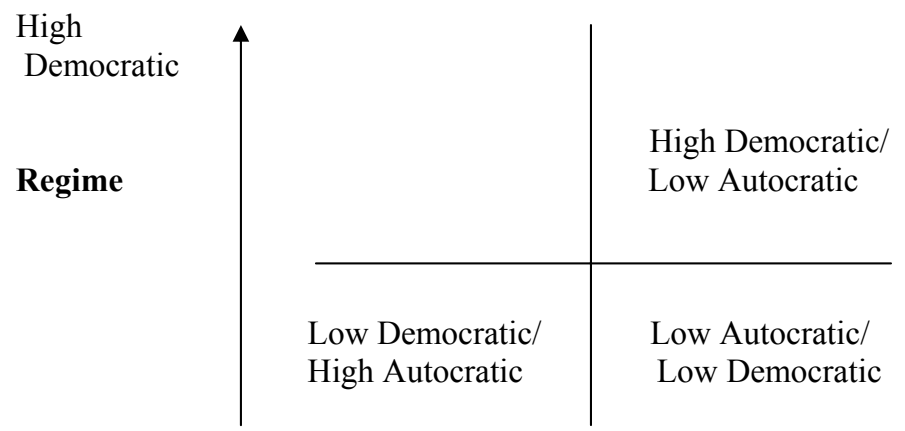

Low Democratic

High Autocratic Low Autocratic

\section{Leadership Styles}

Figure 2.1 is a matrix of three possible combinations of regime types and leadership styles. It shows regime type characterized by a low democratic and high autocratic leadership whereby the style is "boss centred leadership" to that which is low autocratic and low democratic leadership where the style is "subordinate centred leadership". In between are other politicalinstitution combinations. In the context of Nigeria's history, much of the regime-leadership space had been low on democracy and high on militaristic or autocratic style. The matrix on the y-axis shows the regime type (whether democratic or not), while the x-axis shows the leadership propensity. The model is by no means perfect but is rather a simplistic representation to guide discussion on the pattern of leadership observed in our study.

That each public bureaucracy is embedded within its own peculiar political and socioeconomic environments brings us to the questions of applicability and environmental con- 
texts. The most notable historical influence in the development of the Nigerian Civil Service has been the impact of three political regimes: colonial, military and civilian. The military government may not be responsive or obliged to listen to the people's demands because it is an authoritarian, not an elected, government. While an elected democratic government has a duty to respond to the demands of the people, in Nigeria the results have been contrary. The country has largely been under authoritarian regimes with short spurts of reasonably responsive governments. On the other hand, some elected political leaders have been impervious to the demands from the electorates. This is at variance to the ideal construct of a motivated government by Manning, (2001).

Referring to Mesquita and Roots (2000):

"Scholars commonly believe that regime types determine a government's responsiveness to the needs of its population. Cross-country comparisons do not support such a clean conclusion. India is a democracy with poor policies; Korea and Singapore undertook significant economic reforms as essentially one-party States. True, the majority of authoritarian governments failed to promote growth or to gain the business sector's confidence. However, the differences between so-called authoritarian states may be as great as what separates them from the democratic alternatives"

In an authoritarian regime, the leader does not have to satisfy the majority of the electorate through redistributive public policies because his being in power was not due to their voting him in. For example, The "Asian Tigers" (South Korea, Hong Kong, Taiwan, and Singapore), and others Asian countries like Malaysia ${ }^{22}$, China, Thailand, have combined political history with diverse economic systems. Despite this, many have performed quite well in their economic development, a good indicator of the abilities of government or the public service of these countries. How have these countries, with their high state capture and non-participatory governance, been able to maintain economic growth? The basis of the answer is in the socioeconomic policies of their leaders - the leaders developed growth-oriented policies (World Bank, 1996).

Looking at the economic growth of Thailand between 1980-1988, Wong, (1995) believes that after many years of political instability in Thailand, Prime Minister Prem Tinsulanoda "had established himself as an honest broker and it is important to note that he reestablished connections with the bureaucracy and also provided space for economic technocrats to formulate and implement stabilization policies". Although a democratic set-up, it was governed by fragmented parties without strong policy positions. There was no participatory governance, and the governed did not have a voice. Thailand has never been noted for political liberalization or democratization, the leadership role of Prime Minister Prem Tinsulanoda was a key factor that aided Thailand in its economic growth of the 1980s Wong, (1995).

Conversely, existing studies have linked the poor socio-economic development in Africa to leadership failures. Many of these African countries have negative or stagnated growth and although some have recorded some economic growth; Sanbrook, (1985) refers to it as "growth without development". Development is always affected by endogenous and exogenous factors. According to Adamolekun, (1988), an effective leader must have the ability "to adopt policies and strategies capable of providing viable solutions". He believes that many of the leadership qualities that helped produce African political giants like Kwame Nkrumah of Ghana and Sekou Toure of Guinea who led their countries to independence, do not suffice for post-independence development. Shortly after independence, the military took over in many African countries with a promise of better societal transformation, but "continued maintenance of neo-colonial dependent economies whose inherent weakness is exacerbated by corrupt practices" (Adamolekun 1988) has made both the military/autocratic and the civilian/democratic leaders ineffective.

\footnotetext{
${ }^{22}$ Reference Box 1.1 for comparison between Nigeria and Malaysia.
} 
The import of leaders in governance therefore cannot be overlooked because institutional changes usually start from the top. The overall poor performances of some institutions are not always due to poor system of administration, but also to bad leadership. No wonder when the leadership of such institutions are removed, the poor performances are sometimes arrested. It is the duty of the leadership to ensure that the capacities and capabilities of their institutions are properly harnessed in order for them to function properly.

\subsection{Research Deficiencies in Existing Literature}

However, inspite of the obvious role of the leadership, especially political leadership, in the development of the public sector, not many empirical works have been done on this matter especially in Africa and particularly in Nigeria. One can refer to the works of people like Gray and McPherson, (2001) on "The Leadership Factor in African Policy Reform and Growth". They tried to determine what functions African leaders need to perform to help develop economic policy that will eventually lead to accelerate and continuous economic growth. Their study links the quality of leadership with some African countries, such as Zambia which plunged from being the third richest country in Africa in 1972 to twenty-fifth in 1996, with their failure to achieve their potential.

On the role of political leadership, Goldsmith (2001) in his article "Risk, Rule, and Reason in Africa", believes that Sub-Saharan Africa is poorly led because the leaders often refuse to accept good quality policy advice. Personal gain motivates many of the leaders to the detriment of the society-at-large. Equally, Adamolekun, (1988) in his article "Political Leadership in Sub-Saharan Africa: From Giants to Dwarfs" discusses issues that he felt made some great nationalist leaders successful during the nationalist struggle phase, and the phenomenon of leadership failure during the nation-building phase.

There have been some recent attempts to provide new analytical perspectives and country case studies of the regions and sub-regions in Africa. One of such is a recent book, Better Governance and Public Policy: Capacity Building and Democratic Renewal in Africa Olowu and Sako, (2002). It included methodological problems of measuring governance and some countries like Ghana, Nigeria, Namibia and Zambia were case studied. Also, KayizziMugerwa (2003), edited works of some researchers in Reforming Africa's Institutions: Ownership, Incentives, and capabilities. This project specifically looked at past policies of the public service reforms and their impact on the economic development in Sub-Saharan Africa. Repeated emphasis was on African States' weaknesses in institutional capacities.

Balogun (2003) in his article "Performance Management and Agency Governance for African Development: The Search for Common Cause on Excellence in the Public service" looks at the heterogeneity of the African continent that militates against unity of purpose required in the performance management of public service. He also queries the near absolute power thrusted on leadership by the agency governance practice.

According to Ake, (2001:1) African economies have been "stagnating or regressing". He believes that although Africa has been grappling with the issue of development for over three decades, the result has not been very promising. He attributes this to colonial legacy, the corruption of the leaders, inappropriate policies, poor labour discipline, poor planning and incompetent management, and other factors. He opines the claim that, "there has been a failure of development is misleading. The problem is not so much that development has failed as that it was never really on the agenda in the first place".

These authors provide a wide variety of insights into the relationship between governance changes, public service reforms and policy processes. They make suggestions on how to build a viable and effective public and civil services in Africa through improved capacity building, good governance, institutional reforms, accountability and transparency of govern- 
ments and so on. The thrust of this research still maintains that this will not be possible without the explicit support of the political leadership. Although some researchers align with this position (Olowu, 2002; Wescott, 1999: Corkery et al., 1998), much empirical works have not been done in this area, a challenge that the current research hopes to address. As an African saying goes, "the fish starts to rot from the head". The head controls all the essential organs of the body, as the political leadership affects the rest of the government, so if there is a problem with the head, it eventually affects the remaining part of the body.

In Nigeria, some researches have been done on the evolution of the public administration system in relationship to the country's colonial, military and civilian regimes. After independence in 1960, Nigeria was believed to have the potential of becoming a recognised developmental state in view of its large human and natural resources and its Westminster-style democratic federal system of government. Many people refer to Nigeria as the "giant of Africa" because it was a "promising African black hope". However, the outcome in terms of socio-political and economic development, and after more than four decades of independence, remains disappointing.

Many researchers and public policy advisers have grappled to find solutions to Nigeria's developmental problems. In their contributions, Olowu et al., (1997) believe that for Nigeria to achieve its twin goals of democratisation and economic development, the political regime must be committed to reforms and the contents of such reforms. They also believe that political pluralism will assist administrative reforms while authoritarian dominance is a great restraint and that the government organizations should improve service deliveries through direct citizen participation and appraisal. According to Otobo, (1999), Nigeria can only meet the developmental challenges that globalisation presents through public policy addressing three major issues: economic diversification, improved governance environment and development of an effective state capacity.

Salisu (2003) opines that the Nigerian Civil Service must be competent, effective and efficient in order to be able to implement government policies. He believes that to achieve this and eliminate inefficiency and corruption, there must be an efficiency-based incentive structure that links reward to performance. Furthermore, the confidence of the public service must be restored through minimal political interference in their day-to-day work.

Adebayo (2001) assessing the problem of efficiency of the Nigerian Public Service, believes there are five factors that affect performance: institutional, political, psychological, attitudinal and sociological. According to him, institutional factors are faulty recruitment of employees, faulty and frequent postings, inadequate training, deterioration in health, incompetent superior, lack of clear objectives, conflict between administrators and professional officers. For political factors, he refers to such issues including undue advancement, lack of or unhelpful political direction, and the massive purge of the public service in 1975. Finally, he discusses such issues as false reporting, colonial mentality, and false declaration of age under sociological and psychological attitudes. He proffers that efficiency can be improved through the introduction of definite objectives, constant review of programmes, success-seeking approach, delegation, optimum use of talent and ability, reporting, and special merit promotion.

The World Bank (2002) country survey on the "States and the Local Governance in Nigeria" in its bid to learn more about governance in terms of state capacity in Nigeria, as it relates to public financial management and the role of the civil service in the delivery of public services to the populace, states that efforts should first be directed at studying the capacity constraints before any attempts are made on capacity-building. However, it suggests that the Nigerian states need supports in the areas of "modernization of civil services, strengthening budgeting and financial management, and enhancing accountability structures in both the executive and the legislature".

The literature on the performance of the public service in Africa and particularly in Nigeria, shows several research deficiencies. First, the majority of the literatures considered 
contextual factors of governance and bureaucracy in terms of political, economical, financial, organizational structure, human resources management policies, public policies, civil service reforms, some of which this research refers to as intervening variables. Little attention is given to how political leadership affects these intervening variables to inhibit or enhance civil service performance.

Second, although some research has been done on the various aspects of governance as it relates to NPM movement in Africa (Olowu and Sako, 2002; Kayizzi-Mugerwa 2003), literature on leadership, especially on how political leaderships influence governance is rare. The few existing studies use assumptions rather than empirical research (Gray and McPherson, 2001; Goldsmith 2001). According to House and Aditya, (1997), there is "a very limited knowledge-base regarding leadership behaviours of.... non-Western leaders". One of the few exceptions is the Global Leadership and Organizational Behaviour Effectiveness (GLOBE) study, an empirical work involving interviews and focus group research in over 60 countries including non-Western countries and Nigeria. The study focused on organizational behaviour and leadership and tested the hypothesis that "attributes associated with transformational leadership are universally endorsed as contributing to outstanding leadership."

Although assumptions abound as to the relationship between the quality of political leadership and the failure of some African countries to reach their potentials, there is a lack of empirical studies. There has not been a longitudinal study of political leadership over time that notes its influence on governance. This could be because of the long period of colonisation of the majority of the African states and many years of authoritarian regimes with low local voice and lack of press freedom. Given these factors, the majority of researchers in this era have legitimate fear for their lives. As well, many policy advisers and educators are employed by these leaders and thus not in a position to give a true leadership assessment. However, in order to have a complete understanding of the public sector performance, a complete understanding of political leadership as it influences administrative leadership and other contextual factors such as public policy, institutional capacity, and the public service reforms must all come into play. This research is an in-depth study on the role of political leadership as evinced on governance and bureaucracy in a developing economy like Nigeria. The next chapter is the analysis of the role of political leadership and its influence on public policy. 


\title{
3. Political Leadership and its Influence on Public Policy
}

\author{
"The way society responds to the need of the poor through its public policies is the \\ litmus test of its justice or injustice”. (Thompson 1997)
}

\subsection{Leadership Role in Public Policy}

According to Walt (1994), the nature of a political regime will determine the type of policies that it will make. Conventional wisdom holds that democratic governance that promote the involvement of other actors such as political parties, legislature, and civil societies, backed by a competent civil service leads to more transparent and responsive public policies. However, it has been shown earlier that in Nigeria, during both authoritarian/military and democratic/civilian regimes, there has been high state capture and non-participatory governance. Non-state institutional capacity has evolved but primarily in response to the brutality of military rule. These groups have been preoccupied with democratic transition and the enthronement of the rule of law.

Civil society organizations devoted to issues of development are few and unable to provide a credible voice in public policy. The absence of a strong and credible non-state voice allows minimal state commitment to policy objectives, transparency and accountability through public pressure. The survival and success of public policies are barely based on the regime's beliefs and more on leadership qualities. The researcher holds the view that success has far more to do with leadership quality than with a regime's philosophy. The Executive Governors of Lagos State be they military or civilian, performed according to their individual ability within different political regimes.

Many policy advisers and researchers believe that good governance will exist in an environment where there is positive interaction between the public sector and other societal institutions to develop good public policies aimed at the betterment of the majority of the populace (Olowu 2002). It has also been noted that many countries, especially in sub-Saharan Africa, lack good governance because of the non-existence of institutional capacities of knowledgeable experts, coupled with lack of fiscal, economic and technological independence (Mutahaba \& Balogun, 1992, Braton \& Mattes, 2001). It is also opined that effective interaction between political, societal and economic factors such as good human resources management, institutional capacity, civil society, local government, legislature, judiciary, and international policies, make for good governance. This study's findings show that because of the continued immature state of Nigeria's political institutions, the political leadership has considerable influence, in some instances negative, on the public policy process.

In theory, the political leadership is responsible for policy formulation based on the popular will of the people, and it lays down broad political agenda and policy goals that the civil servants should follow. The Chief Executive therefore must accept responsibility for the consequences of state policy. The civil servants on the other hand, should give good and objective advice, and implement the policy applying administrative procedures. In practice however, we observe that between policy formulation and implementation there are no sharp dividing lines, but wide areas of overlaps, as administrators sometimes find themselves in decision-making roles that influence policies (Adebayo 2001). 
A dysfunctional policy process casts administrators in the role of masters of policy. Deference to the political Chief Executive's policy direction, and respect for the administrative leadership's informed recommendations is the hallmark of a harmonious political-policy institution. In other words, politics and administration cannot totally be detached from one another. There must be caution against what Adebayo, (2001) refers to as 'meddling' of politics with administration.

It is evident that the Nigerian system, like that in some other developing countries, has not followed this conventional relationship between political and administrative leadership. This is mainly due to the inconsistent ability of the political leadership to provide policy direction and guidelines to the administrators. It can be argued that the incessant incursion of the military into the affairs of state has contributed to the immaturity of the democratic process in Nigeria. In the main, there have been cases where political leaders have been able to discharge their duties effectively.

Adebayo (2001) ascribes the inability of some political leaders (that is, Ministers and Commissioners who are cabinet members and Chief Executive Officers of their ministries) to perform effectively, to low educational backgrounds ${ }^{23}$; especially during civilian rule, when actors regarded their roles as largely ceremonial. Political appointees who are quite educated, however, come into government with a mind to modernise the system and do away with obsolete rules and regulations associated with bureaucracy. Second, many appointments were because of the roles individuals played in party politics. They are therefore more preoccupied with intra- and inter-party politics and squabbles than with policy formulation and guidelines. Third, the patterns of decision-making during annual budget negotiations involve the administrative leadership as the main drivers of programmes of governments with minimal input of the political leadership (Adebayo, 2001:7724).

Ellis (1996) has highlighted factors such as charismatic leadership, ethnicity and tribalism, dominance of ruling elites, scarcity of resources and backwardness that affect policy making in Africa. In Nigeria, the environment needed for policy-making by both political and administrative leadership is very fragile and sometimes unpredictable due to political instability, ethnic differences and mismanagement of resources. The role of a charismatic political ruler therefore becomes pertinent. The pattern and relative influence of policy-making is not based on the policies of any regime (military or civilian) but on personal conviction about certain policies of the political leaders and their ability to cooperate with the bureaucracy for its implementation. In the current research, policy legitimization and accountability, institutional continuity and episodic policies, and patrimonial disposition of the state are shown to affect the leadership performance in governance.

\section{Leadership: Policy Legitimization and Accountability}

One of the hallmarks of a democratic society is that plans, programmes and policies of government are not at the whims and caprices of the Executive Governors, they must have the approval of the Legislature. According to Olowu, (1990:112) the Lagos State House of Assembly or the Legislature was charged with the power "to authorize, monitor and control the expenditure of state funds through its powers of oversight and the scrutiny of the Audit's annual reports....... The intent is to ensure that it can correct any defects within existing laws with ease and secondly to enable it 'to expose corruption, inefficiency or waste in the execution or administration of laws and in the disbursement or administration of funds appropriated by it". The legislature is therefore mandated to keep watch over the policies of the executive

\footnotetext{
${ }^{23}$ This phenomenon is beginning to change, as some of the Commissioners especially in Lagos State Government are well educated, as they sometimes attend top-notch universities both locally and abroad.

${ }^{24}$ Adebayo (2001) provides a good discourse on policy-making and administration in Nigeria.
} 
and make them accountable to the people. The legislature is also a supervisory body, a watchdog that guards against excesses of the executive in the areas of administration, finance and appointments.

Under military rule, however, both legislative and executive powers are vested in the military ruler. For the greater part of its existence, Lagos State has been controlled by the military. Not accountable to the populace, some military Governors do not follow the due process in the execution of their policies and programmes. Even under democratic rule, the work of the legislature to expose corruption and inefficiency of the executive has not been carried out very effectively. At the Federal Government level, there has been continuous accusation of corruption between the executive and the legislature. On March 22, 2005 Federal President Olusegun Obasanjo, in a nationwide broadcast on the Nigerian Television Authority (NTA) network, spoke on the issue of transparency, accountability and eradication of corruption. He said, "The fight against corruption is meant to be observed within the three arms of government, the Executive, Judiciary and Legislature because corruption will not disappear in our national life if the measures adopted in the fight are designed for the Executive arm or within the Judiciary alone while the "Legislative" arm wallows in corruption."

In a rebuttal culled from the Vanguard News and posted on the Internet March 24, 2005 by Rotimi Ajayi and Kingsley Omonobi, the members of the National assembly protested the accusation. The House denied the allegation and claimed that it has always conducted itself "with integrity, credibility, honour, candour and respectability." This rebuttal came even after a member of the House of Representative had earlier said, "Every facet of the National Assembly stinks with corruption" (INDEPENDENT of March 18, 2005).

Therefore under civilian rule, the legislature has been an ineffective watchdog. Media that are supposed to blow the whistle have been scuttled by the system. During military regimes, harassment, imprisonment and out-right murder have inhibited people from speaking on this matter. During civilian regimes, many compromised themselves through bribery and corruption. The law enforcement agencies also face accusations of corruption. The President retired the Inspector General of Police over allegations of bribery and corruption in 2004. Institutions such as Police, House of Assembly, and the Judiciary that has the power to ensure consistent and systematic compliance, lack a credible enforcement agency.

Corruption is a common phenomenon that cuts across different continents, political institutions, and socio-cultural environments. According to Lipset and Lenz (2000, pp.112-113) corrupt practices were noticed in ancient civilizations of Egypt, Israel, Rome, and Greece. It is an observable incident that occurred throughout the centuries. Like many other concepts, researchers have not been able to come up with a single definition. Sen (1999) sees it as a contravention of established rules and regulations for "personal gain and profit". While Lipset and Lenz (2000) believes that the misappropriation or misuse of public resources and power for private gain and benefit is corruption.

Corruption weakens the ability of governments to provide social and infrastructural services by diverting scarce resources to private purposes. This ultimately reduces the ability of those in authority to provide good living conditions for the governed (Osoba 1996). More than anything else, it reduces the legitimacy of the political system to enforce rules. For this reason legal institutions are vitiated and "bad" behaviour tend to be rewarded. However, corruption is more prevalent in some societies than the others. For example, several African countries such as Democratic Republic of Congo, Rwanda, Liberia, Sierra Leone and some many others, have ended up in debilitating civil wars due to the rent-seeking behaviour of their leaders. The promise of prosperity has ended in mass poverty due essentially to corrupt governance systems. According to Bayart, Ellis and Hibou (1999), classical corruption is gradually infecting the states in Africa themselves.

However, the endemic nature of corruption has led the Federal Government of Nigeria to address the issue head on by establishing several anti-corruptions institutions although suc- 
cess is hard to measure. According to Dike (2005), "Corruption occurs in many forms, and it has contributed immensely to the poverty and misery of a large segment of the Nigerian population." It has subsequently affected the institutions of governance including the processes and mechanisms of monitoring and evaluation.

\section{Policy Monitoring and Evaluation}

Over time policy and institutional evaluation and monitoring began to lose legitimacy. When the Governors were asked if they had any formal system to evaluate their government's policies and programmes, all said that they had an internal one. The critical question is: how does it work? According to Governor GVM3, he held that

"the system has a monitoring apparatus in place. There are institutional monitoring, no need to establish new ones, although there may be need to adjust once in awhile."

Governor GVM4 believed that evaluation should be by giving

"attention to the execution of the various programmes at hand. One should endeavour to visit the projects and see level of performance before payment is made. There may be some falsehood, for quite a few of jobs not done. One must therefore physically visit the projects and ensure that the public servants perform their duties".

Governor GVM7 said that the

"Plans Programme and Budget Bureau under its Permanent Secretary and the Office of the Special Duties under its Commissioner coordinate the various activities of Government."

Governor GVM11 said,

"The Budget and Monitoring Department monitors the implementation. We have teams that checked on the people unknown to them."

During the field research, respondents were asked whether the government had a formal system of evaluating its programmes and projects. $80 \%$ of the respondents said Yes, while $20 \%$ said No. The raison d'être for the responses by both Governors and respondents is that the government had monitoring officers in the Plans, Programmes and Budget Bureau, currently called Ministry of Economic Planning and Budget, to oversee its activities. Some of the responsibilities of assignments of this Department are:

- Preparation of Annual budget of the state government;

- Budgetary control;

- Liaison with the Ministry of Finance on Budgetary and Financial matters;

- Monitoring and control of Economic Planning matters;

- Analysis and evaluation of Government's projects

- Pre-payment inspection of Government projects, and

- Research, Planning, Project Analysis and Evaluation (Lagos State of Nigeria Official Gazette, 2001).

Among its various responsibilities, this Department monitors and evaluates government projects, but it has no mandate to address issues of corruption, inefficiency or wasteful disbursement of funds by the administration to the outside world. The loyalty of the Permanent Secretary and Commissioner is to the Governor. Only an external body empowered like the Legislature can challenge the government on acts of corruption or misappropriation. Civil servants that decide to reveal corrupt practices in government should be ready to lose their jobs. The highhandedness of the military was pronounced because they apparently did not have a supervisory body to report to, or seek approval from in order to carry out certain programmes. Consequently, they did not follow due process, especially in financial issues. According to Shodipe (1997:159) GVC9's government "was an unfortunate inheritor of empty coffers, bad 
debts, harassing horde of unpaid contractors and virtually disreputable treasury. With over 1.68 billion Naira owed to various creditors, Lagos State Government cheques were being dishonored everywhere. The state of excellence which in the days of Governor GVC5 was incredibly buoyant enough to lend money to impoverished states, was now itself a stigmatized prodigal, heading for the poor house."

Transparency and accountability are of great importance in the tenure of any leader because they are the foundation for the nation's socio-economic and political development. As Nigerian President's March 22, 2005 television broadcast puts it "We have never felt shy of our undiluted commitment to eliminating corruption from our national life because it compromises national development, contaminates collective morality and values, distorts national planning, corrodes integrity and discipline, and destroys the foundations of creativity, innovation, and democratic structure and development."

In reference to Governor GVC5's administration, (Olowu, 1990) said that the government tried to render its obligation to the populace by its "consistent effort to plug waste and discourage bureaucratic corruption than most other state governments in the country...(through) an extensive and very elaborate network of funds' monitoring and expenditure". During the Second Republic, GVC5 showed honesty, accountability and transparency in programme implementation. The regime of GVC9 lacked effective programme execution, despite the Governor's own reputation for honesty. The Legislature that was supposed to query the situation only cared about getting what they wanted. It was a hostile environment. By the time of GVC12, which is also a democratic dispensation, both Federal and State Legislatures are accused openly of lack of transparency and corruption.

Under military rule, some Governors in Lagos State nevertheless, exhibited exemplary honesty and transparency. Governor GVM1 exemplifies this by not using his eight years at the helm of affairs to acquire wealth; GVM2 did not seek personal gain or the acquisition of wealth. The instances given are both from the civilian and military accordingly, and some of these individuals were transparent and accountable. Even when erroneous decisions are taken, the people appreciated their sincerity. Accountability helped to improve the performance of public service deliveries and the citizenry appreciated the transparency of the political leadership.

\section{Leadership: Institutional Continuity and Episodic Policies}

The structure of Nigeria's governance has suffered historically from institutional discontinuities. The state has been governed largely by military Governors and alternatively by civilian Governors. These two governance structures are radically different in their intellectual origins, disposition and management structures. In this section we argue that rapid and sometimes sudden changes of Chief Executives of the state and the dissolution of the whole apparatus of government have limited the institution-building and organizational development ${ }^{25}$.

Military Governors have ruled Lagos State for 25 out of 38 years. Ruling without the kinds of checks and balances provided by the Legislature has led to a lack of accountability, to cronyism and corruption. Upon resuming power, civilian regimes inherit this dysfunctional system. There are indications, however, that civilian regimes compound the problems by their lack of "restraint, maturity, and ethos that supports democratic political order in a multiethnic, multi-religious state" (Olowu et al., 1997). The civilian government may therefore find secure anchorage in the command and control system of governance that characterizes the military. Therefore, the democratic system in Nigeria does not necessary exhibit political ac-

\footnotetext{
${ }^{25}$ I make a distinction between organizations and institutions. Institutions are "sets of common habits, routines, established practices, rules or laws that regulate the relations and interactions between individuals and groups", Edquist (1997:7). Organizations are actors such as Government ministries, NGOs, professional associations, universities and others.
} 
countability, a condition that (Adamolekun, 1986:9) refers to as "performance and responsiveness of governmental administration".

Although any military regime in Nigeria is indeterminate, this does not mean that particular sets of military leaders are at the helm of affairs at all times. There have been many coup d'etats, palace coups and counter-coups, a situation that leads to constant changing in the Chief Executives of the state. The instability of the Federal Government reflected itself in the governance of the states. Six Governors ruled within a span of sixteen years, on an average of two to three years. Some of the Governors ruled during politically volatile periods, such as the period of General Abacha when politicians were kidnapped and some killed. Table 3.1 shows the Executive Governors of Lagos State and the number of years in office.

Table 3.1: Lagos State Governors: Number of years in office

\begin{tabular}{|l|c|}
\hline Executive Governors of Lagos State & No of years in office \\
\hline 1. GVM1 & 8 \\
\hline 2. GVM2 (deceaced) & 2 \\
\hline 3. GVM3 & 1 \\
\hline 4. GVM4 & 1 \\
\hline 5. GVC5 & 4 \\
\hline 6. GVM6 (deceaced) & $2 \frac{1 / 2}{}$ \\
\hline 7. GVM7 & 2 \\
\hline 8. GVM8 & $31 / 4$ \\
\hline 9. GVC9 & $2 \frac{3 / 4}{11 / 2}$ \\
\hline 10. GVM10 & 3 \\
\hline 11. GVM11 & 5 \\
\hline 12. GVC12 & 2 \\
\hline
\end{tabular}

Source: Researcher's Survey in 2003

The frequent and sudden change of Chief Executives did little to encourage institutional continuity and lasting policies. Constant change of political leadership does not provide a foundation for a good knowledge of the condition of the state. The Governors have little time to focus on long-term planning. Many only have time to look into immediate problems, like traffic congestion, bad roads, and security. As the Governors knew that they could be removed at any time, they tended to focus on public policy that may be of interest to them and not necessarily in the interest of the state's societal development. Each Governor therefore, had his own priority, which might not necessarily have been in tune with that of his predecessor's policy. The different policies implemented by the various governments to solve the perennial problem of traffic congestion of Lagos State as depicted in Box 3.2 illustrate this.

However, if a leader with good developmental orientation ruled for a relatively long period of time, it helps the country to institute good public policies. Dr Mahathir Muhammed was at the helm of affairs as Prime Minister in Malaysia between 1981-2003. During this period in Nigeria, there were 7 Presidents/ Head of State, while in Lagos State, there were 8 Executive Governors. Within the span of 22 years, Mahathir's economic policy was able to transform Malaysia from "a small-time exporter of rubber and tin into one of the world's top twenty trading countries.... History is replete with leaders who achieved good GDP figures but failed to translate them into equitable distribution of wealth. Not Mahathir: he delivered both overall economic growth and personal economic improvement for ordinary Malaysians. Since 1982 incomes have tripled, the number of poor households has dropped from $35 \%$ to just 5\%, and two-thirds of Malaysians now live in cities" (Idris 2003). 
This is not to imply that a long-term rulership is a sufficient requirement for development. Africa has witnessed sit tight predatory rulers like Mobutu Sese Seko of Congo and Gnasimgbe Eyadema of Togo who left their countries worst than they met them. A government and leadership need policy continuity but a necessary condition is that it is developmentally oriented.

\section{Episodic Policies}

From a socio-political viewpoint, policymaking is essentially a political process where agencies with different concerns try to maintain and broaden their power base (Grindle 1981). However, the development of political institutions in Nigeria is noted for its institutional discontinuity. According to Olowu, (2002:3) "Students of African political and economic institutions point to the time it takes for these political institutions to develop the competence, capacity, and confidence to make positive inputs to the policy process. In fact, they may undermine that very process leading to paralysis and policies that reflects group or private rather than public interest."

The objective of political parties is to garner grassroots support through a manifesto that expresses the desires of the people, helps reduce inequality, and facilitates material advancement that leads to greater community integration. In Nigeria, the military have severely undermined the strength of political parties by ordering their disbandment during periods of military rule. When the military prepare to leave power they invite the parties to regroup under what is often a superficial political umbrella, lacking coherent philosophy and legitimacy. Therefore, the institutional capacities of the political governments are weak. The military is always grappling for legitimacy, while the civilian government is in a constant state of flux. This situation destroys political administrative competence and capacity. The ability to make good public policies is lost in the process.

In her contribution, RPSI said, "there (is no consistency) in the governments' policies. Various governments came up with different policies about road networks and traffic management. The Metroline was conceived by GVC5 to rid the state of its numerous traffic congestions, but the succeeding government of GVM6 dismissed the project. According to the new government, enquiries were not made on the magnitude of the project. The path and electricity consumption of the metro were not taken into considerations." In his own contribution, PSI opines, "Most successive regimes, instead of improving on what their predecessor has done, just abandoned it. For example, the building of the government house had been abandoned since GVM7's regime. Decline in service delivery is due to the fact that successive governments do not usually build on what their predecessor did, but start their own programmes and projects." 
Box 3.1: Example of policy discontinuity on traffic management

One of the perennial problems of Lagos State is the traffic congestion, which can be horrendous. The influx of people into Lagos metropolis from the early 70 s after the oil boom led to vehicular ubiquity and persistent traffic paralysis. Different regimes came up with different decrees, traffic laws and the establishment of organizations like the Road Safety Corps and the Lagos State Traffic Management in order to solve this problem. One of the most popular was the Lagos Motor Traffic Edict of January 10, 1977. It was supposed to reduce vehicular movement by the introduction of Odd and Even numbers to operate at alternative days of the week. People were encouraged to take public transport or develop the culture of car-pooling. Although, this Edict was in operation for about 15 years it was only effective for only a couple of years. After some few years people started disobeying this Edict because of lack of enforcement. Also, the transportation situation has become very precarious that people could not afford to leave their cars at home and go through the harrowing experience of joining public transport, which is permanently inadequate.

Lagos State needed an enduring policy on its transportation system. It was decided that a Metroline should be built. But before GVC5 could start this project, he was removed from office. The abortion of the Metroline service was a major example of episodic policy in Lagos State. The contract for the construction was signed in 1981 with a French consortium, which comprised 19 companies at the cost of 698.45 million Naira. It would have the capacity to carry 44,000 passengers per direction per hour. The passage for the tracks had been identified. The execution period for the project was put at 45 months. This was one of the plans to solve the perennial problem of transportation in the state. The execution of this project would have given the state the following benefits:

- Decongest traffic in the State;

- Reduce mortality rate through car accidents;

- Conserve energy;

- Reduce air pollution;

- Reduce noise pollution;

- Reduce pressure on the road and therefore saves money on rehabilitation;

- Saves time during commuting, etc;

- Improve productivity and subsequently the economy.

Governor GVM6 stopped the construction of the Metroline inspite of the fact that the sum of 70,000,000 Naira initial payment has been made. It was also calculated that the daily proceeds should be able to defray the cost of construction within 15years. However, Nigeria adopted the controversial Structural Adjustment Programme with its attendant devaluation of the Naira. Over two decades after, Lagos State could still not afford to build the Metroline. Up till today traffic congestion is still one of the perils of Lagos State.

Source: Researcher's fieldwork in 2003

This research indicates that every area of social and physical infrastructure has suffered decay and under-investment, due to the poor government performance. Examples show that sometimes it may not necessarily be the fault of the political leadership, but the political system itself. "No differences of ideology or clearly defined principles really exist between one political party and the other to distinguish their attitudes and direction of their programmes" (Adebayo, 2001:78). The military, however, do not have any policy to present to the people, and is therefore under no pressure to deliver on specific policies. Therefore, the inability of political leaders to perform well may not necessary be due to personal inadequacy but lack of established political institutions.

Another reason for institutional discontinuity is that a substantial amount of the state's resources services the government itself, in terms of personnel and overhead cost that make up the recurrent expenditure. From Table 3.2 it can be observed that the recurrent expenditure is generally higher than the capital expenditure. In 1968, the recurrent expenditure of government was $96.8 \%$. This could be expected because the state was created in 1967. Its initial resources were used to develop its institutional capacity. However, "the overall ratio of recurrent to capital expenditure between 1968 and 1978 was $61.5 \%: 38.5 \%$. Similarly, [the] corresponding ratio for 1980-1983 was 60\%: 40\%" Olowu (1990:56). In Table 3.2, the same trend can be observed between recurrent and capital expenditure over the years. The total average in the recorded years between recurrent and capital expenditures is $62.6 \%: 37.4 \%$. 
Table 3.2:Lagos State Government: Recurrent and Capital Expenditures 1968, 1978, 1988-2001 (in Million and Percentages)

\begin{tabular}{|c|c|c|c|c|c|}
\hline Governor & Years $^{26}$ & $\begin{array}{c}\text { Recurrent } \\
\text { (A) }\end{array}$ & $\begin{array}{l}\text { Capital } \\
\text { (B) }\end{array}$ & $\begin{array}{l}\text { Total } \\
(\mathrm{A}+\mathrm{B})\end{array}$ & $\begin{array}{c}\text { Percentage } \\
\text { Difference } \\
(\mathrm{A} / \mathrm{A}+\mathrm{B}) * 100\end{array}$ \\
\hline GVM1 & 1968 & 13.58 & 0.44 & 14.02 & 96.8 \\
\hline GVM3 & 1978 & 127.96 & 32.13 & 160.09 & 79.9 \\
\hline \multirow[t]{4}{*}{ GVM8 } & 1988 & 492.17 & 445.18 & 937.88 & 52.4 \\
\hline & 1989 & 493.38 & 587.71 & $1,081.09$ & 45.6 \\
\hline & 1990 & 825.53 & 575.42 & $1,400.95$ & 58.9 \\
\hline & 1991 & $1,009.19$ & 991.79 & $2,000.98$ & 50.4 \\
\hline \multirow[t]{2}{*}{ GVC9 } & 1992 & $1,962.97$ & $1,457.89$ & $3,420.86$ & 57.3 \\
\hline & 1993 & $2,574.85$ & $2,576.76$ & $5,151.61$ & 49.9 \\
\hline \multirow[t]{2}{*}{ GVM10 } & 1994 & $2,929.21$ & 1,968 & $4,897.21$ & 59.8 \\
\hline & 1995 & $4,329.24$ & 1,402 & $5,734.24$ & 75.4 \\
\hline \multirow[t]{3}{*}{ GVM11 } & 1996 & 5,322 & 4,105 & $9,427.00$ & 56.4 \\
\hline & 1997 & 7,714 & 5,168 & $12,882.00$ & 59.8 \\
\hline & 1998 & 10,343 & 6,490 & $16,833.00$ & 61.4 \\
\hline \multirow[t]{3}{*}{ GVC12 } & 1999 & 12,009 & 5,835 & $17,844.00$ & 67.2 \\
\hline & 2000 & 26,492 & 16,450 & $42,942.00$ & 61.6 \\
\hline & 2001 & 32,141 & 16,774 & $48,915.00$ & 65.7 \\
\hline TOTAL & & 108779.08 & 64859.31 & 173638.39 & 62.6 (Average) \\
\hline
\end{tabular}

Source: Lagos State Government Budget Estimates 1968, 1978, 1988-2001.

The issue of recurrent expenditure being higher than capital expenditure is one of the matters addressed by Public Service Reforms such as right sizing and strengthening the financial management of the civil service. Any conserved resources are anticipated to be channelled to the capital budget ${ }^{27}$, but most of the time this has not been feasible. Table 3.2 shows, that only during the regimes of GVM8 and GVC9 in 1989 and 1993, the recurrent expenditure was less than, or at par with, the capital expenditure (at $45.6 \%$ and $49.9 \%$, respectively).

\footnotetext{
${ }^{26}$ Please note that there are overlaps in the last year of the preceding Governor and the first year of the next one.

${ }^{27}$ In the Lagos State Civil Service one of the reasons for this may be the skewed structure of the organization that is now an inverted pyramid with more senior staff than junior staff. Automatically, this will lead to increase in the personnel cost and other allowances. It should be noted that the percentage differences between the recurrent and the capital expenditure between 1999 and 2001 remained at about 60\%: 40\% despite over 2000 senior staff having been employed during this period; this was because the 4000 staff retrenched were approximately in the range of $35 \%$ senior and $65 \%$ junior staff.
} 
Chart 3.1: Lagos State Government: Capital Expenditure- Sectoral Allocation, 1985-2001

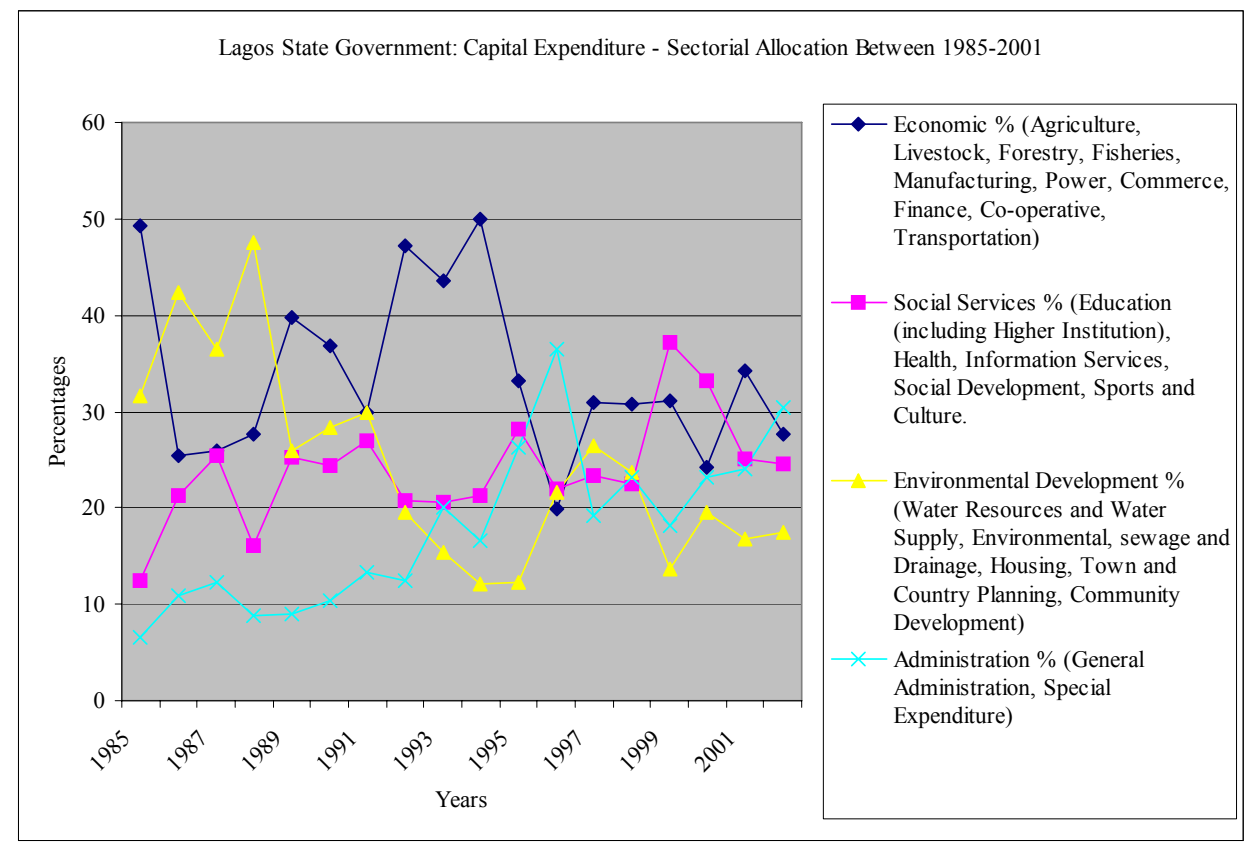

Source: Lagos State Ministry of Finance - Budget estimates, 1985-2002.

Chart 3.1 provides the budget estimates on economic, social services and environmental development sectors in Lagos State between 1985 and 2002. There are no consistent public policies as shown in terms of constant expenditures in any particular sector. For example, GVM6 was noted for his environmental upgrading exercise and the provision of low quality and medium cost housing estates. During his regime, Lagos State took on a new look and was gradually becoming a clean and beautiful state with parks and gardens. This is reflected in the amount of money allocated to environmental development, which came to $31.6 \%$ and $42.3 \%$ in 1985 and 1986 respectively. Although GVM7 spent an almost equal amount in this sector in 1987 and 1988 with an appropriation of $36.5 \%$ and $47.5 \%$, respectively, his effort was more in the rural areas. From GVM8-GVC12, appropriation to this sector continues to decrease. GVC12 allocated the least appropriation to this sector because he encouraged private sector participation especially in the area of waste management. This approach has not been well coordinated and therefore its effectiveness is questionable.

What we observe in the pattern of allocation is the continual swings in the allocation of funds to the different sectors by the various Governors, and sometimes during the same regime. However, of all the Chief Executives, two Governors stood out in their consistency in sectoral allocations. GVM8 was Governor between 1988-1991, and Chart 3.1 shows that he was consistent and this is reflected in the overall success he had during his regime. He made effective use of the institutional capacity at his disposal. By this time, the Structural Adjustment Programme had started to take its toil, but he was able to develop a "determined revenue generation strategy and sound accounting system" (Lagos State Ministry of Information). His overall appropriation (budget estimates) in 1991 almost reached 1billion Naira. However, GVC9 who came in immediately after, though consistent in his sectoral appropriation, was not as successful. His regime lacked the revenue drive of his predecessor, and his appropriation (budget estimates) in 1993 was less than half a billion Naira. Although the sectoral allo- 
cations showed consistency, not much progress was made, due to lack of effective execution of most of his programmes ${ }^{28}$.

The arbitrary sectoral allocation affects all the various sectors: economic, social services, environmental development and administration. Inconsistence in the capital expenditure allocation reflects the lack of sound philosophy in public policy. There are two possible reasons. First, lack of consistent allocation of funds or continual swings in budget allocation may result in fluctuation in development performance and ineffective service delivery. Second, poor performance may be due to ill-conceived or poorly introduced and badly executed programmes.

Successive governments therefore face perennial mounting social problems and tend to devote much of their tenure to tackling basic needs. The populace, however, is more interested in promises to correct the wrongs done to them by the last government as they see the provision or lack of these basic amenities as political weapons used by these regimes to legalise their stay. Table 3.3 reveals the pressing social and physical infrastructural needs of Lagos State as the respondents rated practically every area from security to roads as very strong indicating widespread decay or the absence of service. The rating indicates the government's inability to provide effective delivery services. Practically all the respondents feel that the government needs to improve its social deliveries in Security 63.2\%, Health 59.7\%, Education 56.5\%, Food 56.3\%, Employment 55.9\%, Water 54.7\%, Housing 52.8\%, Waste disposals $51.9 \%$, and Roads 51.7\%. Only Sewage and Transportation scored below 50\% with 49.5\% and $46 \%$, respectively.

Table 3.3: Lagos State: Pressing Social and Physical Infrastructural Needs According to Respondents.

\begin{tabular}{|l|l|l|l|l|l|}
\hline Label & Very low & Low & Fairly strong & Strong & Very Strong \\
\hline Security & 12.8 & 4.8 & 7.2 & 12.0 & 63.2 \\
\hline Health & 4.8 & 4.8 & 12.1 & 18.5 & 59.7 \\
\hline Education & 8.9 & 8.1 & 12.9 & 13.7 & 56.5 \\
\hline Food & 11.6 & 7.1 & 10.7 & 14.3 & 56.3 \\
\hline Employment & 8.1 & 5.4 & 13.5 & 17.1 & 55.9 \\
\hline Water & 11.3 & 10.4 & 9.4 & 14.2 & 54.7 \\
\hline Housing & 16.0 & 6.4 & 6.4 & 18.4 & 52.8 \\
\hline Waste Disposals & 11.1 & 5.6 & 10.2 & 21.3 & 51.9 \\
\hline Roads & 6.9 & 13.8 & 7.8 & 19.8 & 51.7 \\
\hline Drainage & 8.4 & 10.3 & 9.3 & 22.4 & 49.5 \\
\hline Transport & 9.7 & 10.6 & 8.8 & 24.8 & 46.0
\end{tabular}

Source: From the research survey in 2003.

Contributing to this issue, PSSIV believed that, "Service delivery is a physical thing that one can see. So if people cannot see the effect of government they will refuse to do their civil duties. Consequently, if people do not have confidence in government or perceive it as inefficient they respond by refusing to do their civic role like paying tax, an income the government needs badly to perform it social responsibilities." Still on the issue, RSSG opined, "The government does not have any more credibility with the staff and citizenry by not discharging its responsibilities. Government's policies do not aspire to meet the yearning of the people again, although it has the capacity to do this. Government has to pay the workers better salaries, and then it will have the rights to demand for their cooperation and commitment. There are too

\footnotetext{
${ }^{28}$ A lot would be discussed about this regime under political leadership and public service performance.
} 
many wastages and stealing. There must be accountability in the delivery of goods and services. People tend to fend for themselves due to lack of social security."

RPSII opined that, "The factors that affects the quality of public policy have to do with both the leadership and the followership. It is a societal thing - people are no longer committed. Indiscipline in the larger society has affected the whole structure in the service. The people are more concerned about money than what they can give back to the society."

According to PSSI, the failure of public policies is that "some programmes are ill conceived. People are not being carried along. For example the electronic Abattoir, if the inputs of the people have been sought it would have been rejected. Majority of the butchers are Muslims who pray over these animals before they are killed. They would not buy or sell animals that are electrocuted. But the government went to build a gigantic abattoir that is underutilized up till this day. Again during the Second Republic the Federal Government embarked on massive housing projects in order to win popularity with the citizenry. Many of the state governments refused to allocate land for these projects because they feel that such public policy was under their purview. The Federal Government was then forced to build majority of these low and medium house outside the state territories. The targeted people did not benefit because of lack of transportation. Many of the houses were not occupied and they were finally vandalized inspite of the millions of Naira spent on the project."

Despite the apparent deficiency in the formulation, implementation and execution of the some public policies ${ }^{29}$, some administrations were able to make their mark in certain areas such as GVM1- education, roads, health; GVC5-Education, housing, food and rural development; GVM6- infrastructural maintenance and beautification; GVM7-, rural development, education; GVM8- Roads, education; GVM11- security, roads, housing; GVC12- employment and transportation. In summary, DSII said, "A good leader will determine the level of achievement. A good leader must be an all round manager. He must be conversant with the various sectors of the service."

When these Governors were asked about what they felt contributed to the success of their public policies, the answers ranged from public and institutional participation through evaluation and information of government's activities. GVM1 said.

"Each month my government informed the public about what was going on. The Commissioners would inform the press about the activities of their Ministries".

According to Governor GVC5 he said,

"We initiated regular meeting at the levels of the legislature and the executive, the civil service, and the leaders of the party, which constantly evaluating policies, programmes and the implementation of them."

GVM8 said,

"The information machineries were very effective. We had phone-in programmes and village square meetings where the Commissioners, Permanent Secretaries and the Chairmen of the Local Governments give account of their stewardship. The dialogues helped the Government to know the needs of the people. We use the information to meet their requirements and in drawing up budget proposals. The achievements we had

\footnotetext{
${ }^{29}$ Aptly put by Nnamdi Inyama in The Guardian, Monday, November 17, 2003 p. 13, "For a megapolis so richly endowed with whatever it takes in human and material terms, things ought to be a lot better. So much that may be going wrong continue to slide, even further out of control while those that were just right may have begun to slip. The pessimist would say there are just not enough things to celebrate. Granted, Lagos metropolis is like no other in the country. With its problems of dense population locked inside a small land mass, poorly maintained road network chocked by tens of thousands of vehicles in varying State of dilapidation, a people, hardworking and long-suffering, but among whose selling points, discipline and orderliness would obviously not be included, Lagos is indeed special. There is also the on off, up down swing in implementation of Government policies that has seen, even the most laudable programmes, falter. As a result, management of refuse, traffic, enthronement of sustainable transport system, repair or reconstruction of roads have witnessed a seeming reinvigoration that suddenly fell flat on its back, no thanks to the much-touted inadequate financial resources of Government."
} 
(were) through God, cooperation of the staff and the people of Lagos State. I am not saying we were $100 \%$ transparent in our accountability. There were bad eggs. If a man feels he has no security, he would start looking out for his own future. However, the Chief Executive and the leaders must be seen to be transparent and accountable for what they are doing."

\subsection{Institutional Capacity of Government and Public Policy}

Elabassi (2003:44) reported, "The political and administrative environment of policymaking in developing countries is fragile and vulnerable to political instability. The survival of civil servants is not dependent on competence and neutrality, but on the maintenance of strong patron-client relationship that cut across bureaucratic structures." Chapter 5 shows that some of the resource management policies adopted during both the military and civilian democratic regimes had affected the government's institutional capacity to perform important governance functions including policy implementation and execution. Fukuyama (2004:9) distinguishes between two dimensions of "Stateness" as scope and strength or capacity. "It therefore makes sense to distinguish between the scope of state activities, which refers to the different functions and goals taken on by governments, and the strength of state power, or the ability of states to plan and execute policies and to enforce laws cleanly and transparently-what is now commonly referred to as state or institutional capacity."

Other factors also believed to have affected the institutional capacity of government include lack of funding, the Structural Adjustment Programme (SAP), poor management and disruptive policy formulation and implementation. For example in Nigeria initial progress was made in the educational sector by the introduction of the Universal Primary Education in the Western Region in 1957. Subsequently the federal and several other states followed. Of the various social forces driving economic growth, education directly relates to a country's ability to alleviate poverty. The people will have more employment opportunities and better salaries or wages. Their social values and attitudes to life will also be positively affected .It is therefore an important area, but it is subject to the personal philosophy or conviction of the person at the helm of State affairs.

\section{Example: Education Policy}

The capacity of Nigerian government at both federal, state and local levels to give quality education at primary, secondary and tertiary levels, is heavily being criticized. In Lagos State, the eight-year rule of GVM1 (1967-1975), combined with the presence of a competent civil service and staff with administrative experience, helped the young state survive in its early period of existence. This period saw the "boldest profiles of development programmes in Lagos State" (Olowu, 1990). One of the main emphases of the public service's developmental plans was education. Next to GVM1 was GVM2 who assumed entire responsibility for all secondary schools in Lagos State, which is reflected in the 1976/77 fiscal year appropriation budget where education came third with the sum of 23.7 million Naira. Between the end of 1977 through to 1979, during the regimes of GVM3 and GVM4, nothing much was done.

During the time of GVC5 (October 1979 -1983), there was an increase in the appropriation in view of his educational policies. "For its execution, appropriation of 112, 046, 627 million Naira was voted as recurrent and capital expenditure from 1981-1983" (Lagos Ministry of Information). In order to improve on the standard and quality of the work started by GVC5, GVM6 increased on this sector's allocation in 1984 to $6.07 \%$, in 1985 to $9.6 \%$, and 1986 to $16.7 \%$. By 1987, GVM7 allocated $13.9 \%$, and in 1988 , this increased to $14.6 \%$. When 
GVM8 came in 1989 there was a further increase to $16.7 \%$, however by 1990 it slipped to $14.8 \%$, falling to $11.5 \%$ in 1991 . Despite the devaluation of the Naira, the percentage of appropriation given to the educational sector from 1991 to 1999 continues to decrease. This reflects the absence of any major educational policy by GVC9 and GVM10, except Governor GVM11 who established the Lagos State University Teaching Hospital.

Chart 3.2: Lagos State: Percentage of Total State Appropriation for Education, 1983-2003

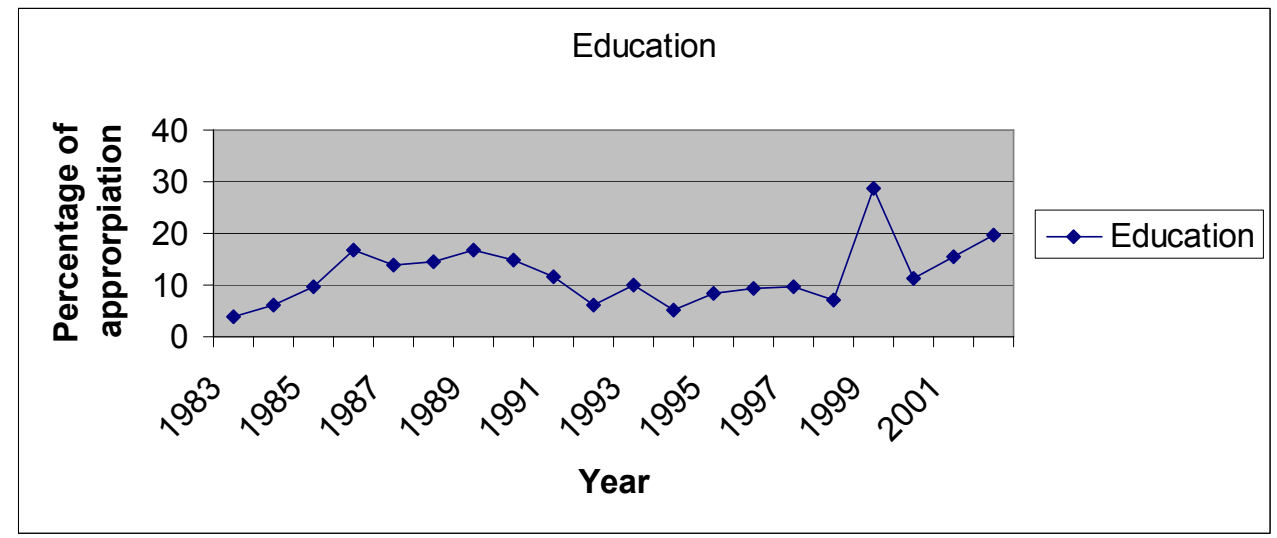

Source: Lagos State Ministry of Finance - Summary of Sectoral allocation for education, 1983-2003

Chart 3.2 shows the trend of education appropriation between 1983 and 2003. Although allocations to this sector from 1992-1998 were below 10\%, the ratio of students per teacher has been between 33:1 to 38:1 as shown in Table 3.4. The high student-teacher ratio indicates the poor quality of education provided. As classrooms are highly congested, the ability of the teachers to give quality time and cope effectively is reduced. School facilities such as laboratories, toilets, recreational facilities, and water are inadequate for the number of students. By the time Governor GVC12 came into governance, the educational sector needed massive revamping. He doubled the amount of money given to this sector, increasing the sectoral appropriation from $14.8 \%$ in 1990 to $28.65 \%$ in 1999 . This huge financial burden on the state could not be maintained. By the year 2000, the appropriation to education was reduced to $11.19 \%$, but rose in 2001 to $15.4 \%$ and 2003 to $19.79 \%$.

However, an interesting development occurred with the increase in funds to the public schools in 1999. The government built some "Millennium classrooms" - decent classrooms with well-equipped laboratories and other facilities. As a result, many parents and guardians decided to send their children back to government-owned schools. This led to $41.8 \%$ increase in the students' population with a corresponding rise in the student-teacher ratio of 53:1. This chaotic situation made Governor GVC12 to return the secondary schools back to their original owners. 
Table 3.4: Lagos State: Secondary Schools Enrolment, 1983-2003

\begin{tabular}{|c|c|c|c|c|c|}
\hline Year & $\begin{array}{l}\text { Number of } \\
\text { schools }\end{array}$ & $\begin{array}{c}\text { Total } \\
\text { Teachers }\end{array}$ & $\begin{array}{c}\text { Total } \\
\text { Students }\end{array}$ & $\%$ Increase & $\begin{array}{c}\text { Students per } \\
\text { Teacher }\end{array}$ \\
\hline $1982 / 1983$ & 319 & 7,813 & 227,170 & & 29 \\
\hline $1983 / 1984$ & 346 & 10,423 & 259,170 & 14.0 & 25 \\
\hline $1984 / 1985$ & 347 & 8,780 & 264,082 & 1.9 & 30 \\
\hline $1985 / 1986$ & 327 & 10,303 & 272,866 & 3.3 & 26 \\
\hline $1986 / 1987$ & 334 & 10,078 & 297,605 & 9.0 & 30 \\
\hline $1987 / 1988$ & 342 & 12,053 & 336,396 & 13.0 & 28 \\
\hline $1988 / 1989$ & 342 & 12,071 & 373,555 & 11.0 & 31 \\
\hline $1989 / 1990$ & 342 & 12,489 & 347,276 & -7.8 & 28 \\
\hline 1990/1991 & 342 & 13,275 & 417,045 & 20 & 31 \\
\hline $1991 / 1992$ & 342 & 15,594 & 477,607 & 14.5 & 31 \\
\hline $1992 / 1993$ & 342 & 16,390 & 540,819 & 13.2 & 33 \\
\hline $1993 / 1994$ & 355 & 16,828 & 599,142 & 10.7 & 36 \\
\hline $1994 / 1995$ & 360 & 17,104 & 629,286 & 5.0 & 37 \\
\hline $1995 / 1996$ & 362 & 18,315 & 643,170 & 2.2 & 35 \\
\hline 1996/1997 & 363 & 18,455 & 668,725 & 3.9 & 36 \\
\hline 1997/1998 & 363 & 17,463 & 656,617 & 2.0 & 38 \\
\hline $1998 / 1999$ & 364 & 17,632 & 672,601 & 2.4 & 38 \\
\hline $1999 / 2000$ & 365 & 18,407 & 699,561 & 4.0 & 38 \\
\hline $2000 / 2001$ & 365 & 18,566 & 992,474 & 41.8 & 53 \\
\hline $2001 / 2002$ & 323 & 17,067 & 657,143 & 33.7 & 39 \\
\hline $2002 / 2003$ & 293 & 17,298 & 618,842 & -5.8 & 36 \\
\hline
\end{tabular}

Source: Lagos State Ministry of Education (2003)

It was a major policy reversal of GVC12 to undo the action taken by Governor GVM2 almost 24 years earlier and return ownership of the secondary schools to their original religious and private organizations. However, by this time many of the organizations did not have sufficient institutional capacities and financial resources to run the schools. His action was pertinent in view of the large sum of money the government was paying on recurrent and capital expenditures to operate these schools. Furthermore, the government could not afford to finance qualitative and free education at all levels ${ }^{30}$. The need for qualitative education cannot be over emphasized because the ability of a country to provide good education to its citizenry relates to the quality of personnel and policies it will have for its nation building. GVC9 said,

"It was my wish to return schools to voluntary agencies. I am aware that government will not be able to competently run the schools especially in the area of discipline. When I started the move to transfer the schools, the House of Assembly resisted me. They said that the christians would benefit more over the muslims".

Table 3.5 shows the educational policies of the various Governors and the effect of their course of action.

\footnotetext{
${ }^{30}$ Despite the inconsistencies in allocation of funds for education in Lagos State, it is still one of the greatest revenue-consuming social services. However, many factors still affect the ability of the state to produce qualitative education because of the large number of people into the State who came to take advantage of the free education policy of the State. This is evinced in the student-teacher ratio in Table 5.8 between 1983-1993 with an average ratio of $32: 1$.
} 
Table 3.5: Governors and Educational Policies

\begin{tabular}{|c|c|}
\hline Governors & Educational Policy \\
\hline GVM1 & $\begin{array}{l}\text { Unified the educational policies of West- } \\
\text { ern Region and that of Lagos Province }\end{array}$ \\
\hline GVM2 & $\begin{array}{l}\text { 1. The Government took over the entire } \\
\text { secondary school system from private } \\
\text { schools and missionaries to enforce uni- } \\
\text { form standards. } \\
\text { 2. Quantitative expansion of schools }\end{array}$ \\
\hline GVM3 & $\begin{array}{l}\text { Introduction of Universal Primary Educa- } \\
\text { tion (UPE) scheme. Government stopped } \\
\text { charging tuition and other fees. Expan- } \\
\text { sions of existing secondary schools con- } \\
\text { tinue. }\end{array}$ \\
\hline
\end{tabular}

1.To cope with acute shortages of classroom, two to three-shift school system was introduced. Students attended either morning, afternoon or evening session.

2. Dissolution of Teaching Service Commission and the Schools Management Board

\section{GVC5}

\section{Elimination of shift system}

2. Abolition of boarding schools

3. Abolition of Common Entrance Examination

4. Automatic admission into secondary schools

5. Introduction of free and universal education at all levels.

6. Establishment of Schools Management Board

7. Renewed efforts in the establishment of tertiary institutions e.g. Technical Schools, Colleges of Education, Lagos State University

\section{Effect}

Consolidated the educational policy of Lagos State

1.The take over led to enormous financial and managerial burden on the state government

2.High pupil/teacher ratios in both primary and secondary schools

Recurrent expenditure shot up and there were acute shortages of classroom. Parents were requested to assume responsibilities for their children's books and other materials
1.This reduced the standard of education as many students had only three hours of teaching contacts with the teachers. This also lead to a sporadic expansion

of private and illegal schools with exorbitant school fees.

2. A chaotic school administration and insufficient supervision of schools.

\section{Successful and sustained.}

2. Establishment of neighbourhood schools

3. Increase in the intakes to secondary schools

4. Same as 3 above

5. Relieved parents of financial responsibility of paying school fees. Increase in schools enrolment and quantitative education.

b. Increase in students and schools ratio. Schools in the Lagos metropolis were highly congested.

c. The quality of the structure of the classrooms was poor. Deplorable environmental conditions for schools in the metropolis

d. Higher teacher/pupil ratio in the primary schools in the metropolis.

e. Government lost the battle to proscribe private primary schools.

6. For effective administration and supervision of free education programme

7. To meet the manpower demand of the State

1. Improvement in learning environment. Phased classroom replacement programme with science equipment and laboratories

2. To improve on the quality of education

3. Same as 7 above

1. Improvement on existing facilities and provision of new classrooms and laboratories.

b. Inspections of schools by Inspectorate division to ensure high-quality teaching. 


\begin{tabular}{|c|c|c|}
\hline \multirow[t]{2}{*}{ Governors } & Educational Policy & Effect \\
\hline & $\begin{array}{l}\text { 2. Establishment of fee paying model col- } \\
\text { leges in the rural areas } \\
\text { 3. Same as } 3 \text { above }\end{array}$ & $\begin{array}{l}\text { 2. Reintroduction of boarding schools. } \\
\text { b. Reintroduction of payment of school fees in some } \\
\text { schools. } \\
\text { c. Helped to open up the rural areas these schools } \\
\text { are located. } \\
\text { 3. Same as } 3 \text { above }\end{array}$ \\
\hline GVM8 & $\begin{array}{l}\text { 1. Establishment of Primary Schools } \\
\text { Management Board } \\
\text { 2. Establishment of Teaching Service } \\
\text { Commission } \\
\text { 3. Establishment of Local Administrators } \\
\text { of Education } \\
\text { 4. Inauguration of Board of Trustees for } \\
\text { the management of State's Education En- } \\
\text { dowment Fund } \\
\text { 5. Introduction of State wide Common } \\
\text { Entrance into Secondary schools, Techni- } \\
\text { cal colleges etc } \\
\text { 6. Resuscitation of boarding facilities to } \\
\text { some State's owned Secondary school } \\
\text { 7.Increase in the Staff strength of both } \\
\text { primary and secondary schools }\end{array}$ & $\begin{array}{l}\text { 1.To facilitate the smooth and successful running of } \\
\text { education in the State } \\
\text { 2. To improve educational standards in the State. }\end{array}$ \\
\hline GVC9 & Continuation of free education & $\begin{array}{l}\text { The appropriation given to education continues to } \\
\text { decline inspite of the devaluation of the Naira. Ul- } \\
\text { timately, the quality of education declined, and } \\
\text { many private secondary schools were being estab- } \\
\text { lished. Demonstrations by University lecturers for } \\
\text { under funding of Universities. }\end{array}$ \\
\hline GVM10 & Continuation of free education & Same as above. \\
\hline GVM11 & $\begin{array}{l}\text { Establishment of Lagos State University } \\
\text { Teaching Hospital }\end{array}$ & Establishments of more Private Universities. \\
\hline GVC12 & $\begin{array}{l}\text { Return of Secondary schools to original } \\
\text { owners. }\end{array}$ & $\begin{array}{l}\text { Try to save the chaotic State of the education sector } \\
\text { by injecting more funds }\end{array}$ \\
\hline
\end{tabular}

Source: A summary by the author from the information collected from the Lagos State Ministry of Education and Lagos State Ministry of Information.

The researcher suggests that the personal philosophy and leadership disposition of a Chief Executive tend to drive their public vision and the policies derived from it. GVC5 believed passionately in education and his party made education the central plank of its manifesto. His educational policies subsequently derived from his vision of a literate society. However, because of inconsistency in the various regimes' educational policies, the institutional capacity of this sector has been undermined. Further, the absence of legitimate and effective non-state institutions to provide alternative policy perspectives has not helped the matter. opined,

Commenting on the need to revive the institutional capacity of government, GVM8

"The bureaucracy needs a sophisticated civil service. There must be an institutional arrangement like the civil service school. We must give authority back to the civil servants who are used to following rules to implement Government policies. We need to train and refashion the Civil service."

In his comments, PSSII stated, "The institutional capacity of the civil service has been eroded. There is need to carry the civil servants along in the implementation of the policies. The government needs to disseminate information. The government of GVC5 did in 1979. 
Staff are no longer involved in the policies of government. Staff now leave their jobs for personal work. There is no more commitment. There is need to build more confidence in the staff. On the part of the citizenry, they should be informed through radio jingles, television programmes, and the newspapers about government's policies. The government should be accountable to the people. That way many people will stop regarding Lagos State as no man's land. People would respond and be more responsible."

\subsection{The Patrimonial Disposition of the State and Impact on Public Policy}

In the mid-seventies, the Nigerian Government embarked on industrial development to make essential commodities accessible to the majority of the people and to generate an environment of self-sufficient and independent economy. In spite of the billions of Naira the Federal Government invested in these public enterprises, in 1988 the chair of the Technical Committee for Privatization and Commercialization (TCPC) of these enterprises was quoted by (OyelaranOyeyinka et al., 1997:2) as saying that the performances of some of these public enterprise were below expectations due to the following problems:

- Misuse of monopoly powers;

- Defective capital structures resulting in heavy dependence on Government for their operation;

- Bureaucratic red-tapeism in their relation with supervising Ministries, and

- Mismanagement, corruption and nepotism.

This observation is usually caused by patrimonial tendency of a state whereby persons are placed above institutional rules. Evans, (1989) describes three types of state namely, predatory, developmental and intermediate. In the predatory state the bureaucracy is characterized by a system whereby rule-governed behaviour in the lower cadre of the public is lost because of personalism and plundering at the upper echelon of the service. The situation leads to individuals having maximum free rein. A developmental state exhibits the Weberian bureaucracy as portrayed in Table 2.1. The intermediate states, is between these two archetypes, which some analysts refer to as "weak" and "strong" states. An indeterminate state exhibits the characteristics of patrimonial tendency or 'prebendalism'.

According to the theory of 'prebendalism', "State offices are regarded as prebends that can be appropriated by officeholders, who use them to generate material benefits for themselves, their constituents and kin groups. In Nigeria, the statutory purposes of such offices became a matter of secondary concern. Nigeria, during the Second Republic between 1979 and 1983, evolved into a full-fledged 'prebendal Republic.' The state was a national cake to be divided and subdivided among officeholders. Politics degenerated, as the scholar Claude Ake has pointed out, into an unrelenting war to acquire, defend, or gain access to state offices." Joseph (1987).

Public policies in Nigeria are influenced by patrimonialism or prebendalism. Several federal projects including the Ajaokuta steel company, Katsina rolling mills, Iwopin paper mills, Bacita sugar industry and fertilizer plants have been turned into white elephants. The establishment of some of the enterprises is not based on solid feasibility studies; many are located in areas that are not economically viable in terms of access to raw materials or the end users. Some project locations are due to the sway of some influential person from that community and do not reflect their viability. The project becomes political compensation for election support or a demonstration of political importance in the community. Most of the time, project management is left in inept hands.

All the elements of good public policies that help establish good governance are thereby lost. Hyden and Braton, (1993:7) identified four fundamental elements of governance as level of trust, mutual relationship between the government and civil society, level of ac- 
countability, and the nature of authority exerted. These fundamentals tend to be missing at the different levels of governance. Elements of patrimonial and prebendalism are also experienced at the state level. Sometimes, relatives and the party faithful receive contracts and consultancy positions, despite their incompetence to do the job. This situation contributes to shoddy work or abandonment of such projects ${ }^{31}$. To redeem the original investment, another financial allocation will be set aside to repeat work or the record may falsely show that the work has been done.

$\mathrm{n}$ his comments on the public policies and the achievements of government, GVM4 remarked, "Many things have changed. It was not like of old because the politicians have become a problem in the ways they do things. During the time of Babaginda the civil servants became more politicized. There is too much fraud, not much commitment, and the bureaucracy became unwieldy. Achievements of governments are very low, and this can be attributed to poor public policies. Recruitment should be cut down, as there are too many idle hands. The salaries should be commensurate with the work done. There should be stricter supervision. The whole system is chaotic, embarrassing and corrupt." Lagos State is still weak in both state and non-state institutional capacities for its public policy process to be effective. The next chapter explores the role of political leadership in the performance of the public service. It specifically discusses political leadership competence on public policy decision-making and problem solving in the governance of the Lagos State Civil Service.

\footnotetext{
${ }^{31}$ Examples of these would be discussed extensively in chapter three under Leadership and Public service Performance.
} 


\title{
4. Political Leadership and Public service Performance
}

\author{
"The trouble with Nigeria is simply and squarely a failure of leadership" \\ (Achebe, 1983)
}

In the late 19th century, Lagos started as an agricultural and fishing community with predominately Yoruba inhabitants. In view of its strategic location along the Coast of the Atlantic Ocean in West Africa, it soon became an important commercial center, initially trading with other neighbouring Yoruba tribes and the Binis. In 1861 King Dosumu, following a kingship tussle in 1860, ceded Lagos to the British Crown, and between 1861-1950, it was administered separately as a "city-state", with its own governorate administration. With the 1951 Macpherson Constitution, it became both a colony and a federal territory (when the latter was excised from the Western region in 1953) under a single administration. This singular administrative set-up led to some problems.

According to Olowu, (1990:43) "The first problem was that of fragmented political and administrative authority. No one government was responsible for area-wide services such as transportation, water and planning. Each governmental authority approached its own task in its own parochial way, unmindful of the socio-economic consequences for a fast growing metropolitan population. Besides, there was an additional uneasy division of authority among the different ministerial departments in the federal on the one hand, as well as within the Western Regional Government Ministries on the other".

This fragmented political and administration authority ultimately led to "continuous impoverishment and truncation of community services" ${ }^{\text {32 }}$. In 1960 Nigeria gained independence from Britain, with Lagos as its federal capital. However, Lagos State was created in 1967. The Federal Government did not want Lagos State to be created but had to succumb to the indigenes' agitation for their own state and Colonel Emeka Odumegwu Ojukwu's cessation plan made the Federal Republic of Nigeria (FRN) to remold the structure of the country from four regions into twelve states. The newly created state therefore needs political leaders that would help to chart its developmental paths in terms of its public policy.

This chapter discusses the role of political leaders in public service performance under the topic, leadership competence on decision-making and problem solving in the governance of the Lagos State Civil Service. Due to the qualitative approach employed in this research, this section may appear to be subjective or uncritical of the opinions of the political leaders surveyed. The format adopted in the chapter is deliberately descriptive aiming rather to present the facts and historical events as they are. Under two other separate chapters -Institutional Capacity and Public Service Performance; and Civil Service Reforms and Public Service Performance, we have analyzed the actions and outcomes of the political actors more critically. It is hoped that this approach will help to reduce reader's confusion, as well as remove repetition and redundancy.

The researcher also based her analysis on objective criteria that relied on publicly available historical data on the various governors. A developing country like Nigeria suffers

\footnotetext{
${ }^{32}$ For more information about the historical evolution of the administration of Lagos see I .O Osokoya 1995 Alhaji Lateef Jakande: The Educational Reformer; Dele Olowu 1990 Lagos State: Governance, Society and Economy; A.A Aderibigbe, "Early History of Lagos to about 1850" in a. B Aderibigbe (ed.), Lagos, The Development of an African City (Nigeria, Longman, 1975), pp. 1-26 and L.K. Jakande, The case for Lagos State (Lagos, John West Publications, 1962).
} 
from poor data collection, it is hoped however that a combination of the respondents' evaluation (subjective information) supplemented with objective data will provide a robust basis for understanding the performance of the regimes.

The political leadership, precisely, the Executive Governors of Lagos State were interviewed. In the interviews, 12 questions were asked that ranged from the Governors' assessment of themselves as visionary leaders, to their thoughts on transparency and accountability in the public service. These Governors are referred to as Governor ${ }^{33}$ GVM1 - Governor GVC12. Governors either not interviewed or deceased, are referred to as GVM2, GVM6 and GVM10 respectively. The names of the Governors are in appendix 111.

\subsection{Leadership Competence on Decision-making and Problem-solving}

This research focuses on the higher echelon of the civil service, especially the political and administrative leadership. Top management in the civil service exerts considerable power over the decision-making machinery. Like senior managers in business organizations, they influence the decisions made over such issues as capital and budgetary allocations, recruitment, retention and retirement, and other strategic policies.

The nature of a political regime tends to determine the types of policies that it will make. Democratic/civilian regimes encourage participatory governance, while authoritarian/military regimes support non-participatory governance. Conventional wisdom holds that democratic governance that promotes the involvement of other actors such as political parties, legislature, and civil societies, backed by a competent civil service leads to more transparent and responsive policies (Olowu 2002). However, this research aims to show that the survival and success of public policies are not necessarily based on regimes philosophy but on political leadership qualities and beliefs.

Theorists of decision-making have all come up with various ways to promote optimal decision, many of which tend to overlap. Weber, (1947) postulates that a formal organization must apply the rational-legal authority, which empowers the management to make rational decisions or decisions based on logic and not emotions. The term rationality refers "to the decision-making process that is logically expected to lead to the optimal result, given an accurate assessment of the decision maker's value and risk preferences", (Bazerman, 2002:4). A rational decision-making process directly or indirectly take the following steps: (1) define the problem; (2) identify the criteria; (3) weight the criteria; (4) generate alternatives; (5) rate each alternative on each criterion, and then (6) compute the optimal decision.

However, Simon, (1957) in his Nobel Prize-winning work, postulates that decisionmaking is better understood by understanding the actual action that has taken place rather than "what should be done". He argues that although people try to make rational decisions, the process is restricted by many limitations such as information about the problem being either inadequate or unavailable, the perception or the judgment of the person making the decision, time controls and others. Perceived, imagined or unanticipated demands both inside and outside organizations also affect the level or degree of rationality that is applied by decisionmakers. Due to the foregoing reasons, decision-making is "bounded" by these inevitable human conditions. Simon therefore postulated the concept of bounded rationality. A situation of "satisficing" arises whereby the choice made satisfies and suffices the circumstances, but it is not the optimal decision for the situation.

Researchers in decision-making process have loosely divided the process into two parts, namely, prescriptive and descriptive models. Prescriptive model attempts to develop a

\footnotetext{
${ }^{33}$ See chapter 1 . GV refers to Governors; $\mathrm{M}=$ military, $\mathrm{C}=$ civilian, while the numerical number represents in ascending order the period of their tenure.
} 
scientific or mathematical process to make optimal decisions. Descriptive model, however, looks at the bounded ways in which people actually make decisions. Governments and multilateral organizations such as the World Bank and donor agencies working on the problems of the public sector in sub-Saharan Africa have applied the descriptive model, however as noted, some of their decisions were based on inadequate or lack of information. So much so that there were not proper analyses of the problems, and the tendency was to apply the same solution to various problems. The lack of accurate assessments in the decision-making process is what Olowu and Adamolekun, (1999) refer to as the diagnosis and prognosis being wrong.

\subsection{Lagos State Governors Reviewed}

Many factors affect the decision making process of political leaders. In Africa and especially in Nigeria it is believed that the decision-making process is influenced by patrimonialism, incompetence and opportunism (Olowu et al., 1997; Otobo, 1999). Commenting on political leadership at the state-level of governance in Nigeria, Olowu, (1990:10) opines that the "statelevel leadership, either civilian or military, are ill prepared psychologically and intellectually to meet the challenges of development thrust on them by the people through the constitution." However, he noted that despite this national sea of incompetence, there are islands of governance with relatively good political leadership. Supporting this view, informant PSSIV said "the civil service was better during the time of GVC5. He had a better experience at governance than many of the other leaders. He had a very good leadership quality. He was hardworking, fair-minded, and forthcoming. He pursued the cardinal programme of his party."

The root of ineffective decision-making may thus be found not only in the lack of preparation of the leadership for the complex political problems that they eventually face, the selection process is often equally flawed. For instance, the selection of military Governors or the election of the civilian Governors is not necessarily based on a record of effective leadership, or administrative competence supported by optimal decision-making or effective problem solving. According to RPSI "there is widespread nepotism, and individuals are sometimes appointed to state offices without adequate qualification." The research tried to analyze the policy thrusts of the various Governors and tried to deduce how their decision-making machinery supported or marred their governance period and their roles as leaders.

\section{GOVERNOR GVM1 1967-1975}

GVM1 was the first Governor of Lagos State. According to him, although "the appointment was thrusted" on him, he saw the post as "a challenge and the responsibility very daunting". He came to power at a precarious period when the future of Nigeria as a nation was uncertain and doubtful. He became Governor on the eve of the Nigerian civilian war, when the Military Head of State Lt. Colonel Gowon announced the creation of Lagos State on May 27, 1967 by Decree 14 of 1967 . The problem faced by the newly created state was that of identity. Lagos Island was the administrative capital of Nigeria by 1960, although it had been a financial and commercial center since 1861. The convergence of people from varied backgrounds and cultural diversity created the perception of Lagos as a no man's land. This presumption tended to be provocative and frustrating for the indigenes to the point where they felt "disenfranchised and wanted their own state," where they could shape their own destiny.

According to Governor GVM1 however, the Federal Government did not want Lagos State to be created. Therefore at inception, this newly created state was stifled of funds, while the other

"newly created states in the Eastern part of Nigeria were given money to establish. Lagos was given nothing. It had a miserable N 10,000 one line-vote, which was the regu- 
lar appropriation that used to be given to Lagos when it was a Federal territory. Some people wanted to prove that Lagos could not look after itself".

It was therefore pertinent to develop key plans, programmes and policies to chart the developmental path of the new state. This was very challenging because of the paucity of funds under the circumstance; there was no money to initiate capital projects or to build administrative capacity.

According to Shodipe, (1997:28), the Governor "merely summoned a dazzling, inventive capability, ingeniously engaging the challenges of governance with austere martial discipline and candour. Since the money was not there to be strewn in the air in lavish ostentations, he basically prioritized the growth of the state". One of the major programmes embarked upon was the "network of roads" called the "spatial integration strategy"34. This helped to improve on communication and integration between the various communities. It also facilitated the promotion of the main-stay of the people - commerce and industry. It equally made it possible for people to stop transversing from neighbouring states before reaching Epe and Badagry divisions of the state. Further, Governor GVM1 said that he did not want to "be taking permission from other Governors in order to get into his own state".

During the 1970-74 fiscal years the actual capital expenditure spent by this Governor on transportation (roads, waterways, bus services) was 40.8 million Naira, which was almost half of the 86.1 million Naira spent on all other areas like health, education, housing, industry and commerce etc. combined. RPSI believes that "GVM1 was a visionary Governor. He built the Badagry-Itoikin expressway that linked the state to the neighbouring Benin Republic, and this helped with international connections and trade with other countries along West African coast." This road was the first ultra-modern dual carriageway in Nigeria and it was labelled "Route Achievement", because it became the golden gateway to the Economic Community of West African States (ECOWAS). A number of industries and socio-economic facilities sprang up along this route including the Federal Housing Project (FESTAC), Trade Fair complex, Volkswagen assembly, Lagos State University, and Satellite Town. He also built major highways within the State, like Epe - Ikorodu - Agbowa to Ijebu-Ode, Otta-Ijora-Badagry, Igbogbo, Ilado, Ojo, and Akowonjo. These roads also helped to open up the hinterlands to the major towns.

Supporting this, RSSG opines that the building of the road networks was a major public policy thrust of GVM1 because it made the state cut itself from the apron strings of the "old Western region" and proved that it was really an independent state. It also made the state more accessible to investors and opened it up for commerce and industries. It is no wonder that Lagos remains the "largest industrial and commercial center" in Nigeria. Table 4.1 shows that although it is one of the smallest states in Nigeria in terms of Land area, 465,100 square kilometers (17.3\%) of Nigeria's 12,749,400 square kilometers land area; it has the highest road density of 709 meters per kilometer by 1978/79. GVM1 was one of the Governors that built this foundation.

\footnotetext{
${ }^{34}$ Road networks was a major programme under the Lagos State Fourth National Development Plan, 1970-74; (Lagos State Programmes Ikeja, 1981). It should also be noted that the Federal and the old Western Region Governments contributed to the development of roads in Lagos State. Table 3.1 shows Lagos State as having the most dense road networks in relationship to the land areas of other States by 1979.
} 
Table 4.1: Nigeria: Road Density in Relationship with the Land Area of States 1978/1979

\begin{tabular}{|c|c|c|c|}
\hline States & \multicolumn{2}{|c|}{$\begin{array}{c}\text { Land Area } \\
6000 \mathrm{~km}\end{array}$} & $\begin{array}{c}\text { Road Density } \\
\text { Meters per } \text { km² }^{2} \\
\text { (relative position) }\end{array}$ \\
\hline Lagos & 17.3 & 465.1 & $709 \quad$ (1) \\
\hline Ogun & 16.4 & 350.4 & $456 \quad(2)$ \\
\hline Cross-River & 28.6 & 850.9 & $372 \quad(3)$ \\
\hline Imo & 12.7 & $1,025.1$ & $366 \quad$ (4) \\
\hline Ondo & 20.5 & 478.2 & $357 \quad(5)$ \\
\hline Bendel & 26.3 & 835.7 & $328 \quad(6)$ \\
\hline Oyo & 46.6 & $1,281.7$ & $215 \quad(7)$ \\
\hline Anambra & 17.3 & 961.05 & $179 \quad(8)$ \\
\hline Kano & 45.1 & 842.9 & $158 \quad(9)$ \\
\hline Plateau & 54.2 & 536.6 & $138 \quad(10)$ \\
\hline Niger & 45.4 & 319.8 & $130 \quad(11)$ \\
\hline Benue & 51.1 & 866.4 & $111 \quad(12)$ \\
\hline Bauchi & 65.5 & 399.1 & (13) \\
\hline Gongola & 59.9 & 473.1 & (14) \\
\hline Kwara & 20.8 & 588.4 & (15) \\
\hline Kaduna & 67.8 & 845.1 & (16) \\
\hline Borno & 11.6 & 693.3 & (17) \\
\hline Rivers & 60.4 & 510.5 & (18) \\
\hline Sokoto & 101.1 & 423.6 & (19) \\
\hline Total/Average & 857.6 & $12,749.4$ & 214 \\
\hline
\end{tabular}

Source: Adapted from Dele Olowu 1990 Lagos State: Governance, Society and Economy Pg. 29

The construction of the vast network of roads led to the displacement of people and the destruction of many homes, which created a crisis in Lagos State at this period. However, the Governor was able to reduce tension and minimize violent reaction through his ability to convince the people that the action was for the betterment of the state. He was sympathetic to the plight of the people and was able to explain the reason behind the government's actions. One explanation was that the only bridge that linked Lagos Island with the mainland was getting defective due to old age and corrosion. Lagos Island plays the roles of commercial and financial centers, as well as federal and state capital. The Carter Bridge, which was then the only avenue into the Island, was clogged with traffic jams, leading to long hours of unproductive driving and frustration. Inevitably, the situation began to exert adverse effects on commerce and government transactions. Since the livelihood of the people also depended on this, they listened to the explanation of the Governor. The Governor was also able to gain the people's support by giving them alternative accommodations and resettlement in a new area called Surulere. This endeared him to the citizenry and created elements of trust between him and the people (Shodipe 1997).

GVM1 also left an enduring and positive legacy in the areas of education, public buildings, shopping precincts, and property development. RPSII summaries it up by saying, "GVM1 did well to build a good foundation, others just built on it". He took a giant step that helped to move the State forward. Commenting GVM1 said,

"I have to complement the crops of civil servants that worked with me. They were upright and dedicated. I had a very strong team, for example my Secretary to the State Government, Permanent Secretary, Ministry of Finance, Legal Secretary and Principal Secretary to the Military Governor. It was teamwork. I must also commend the efforts of my cabinet. The Commissioners were relentless in their efforts to make the young state 
succeed. I also tried to give a good leadership. I tried to be honest ${ }^{35}$ and straightforward. One should live by the tenets one preaches".

\section{Summing Up on GVM1: Factors Influencing Governance and Leadership}

This Governor set the pace employing the most meagre of resources to achieve landmark achievements. He was Chief Executive in a time of considerable uncertainty, undefined political and geographic boundaries and more pertinently, of almost non-existing institutional capacity and only an emergent governmental capability. The following is a summary assessment of the Governor:

- Personal qualities: disciplined, frugal in spending state resources, committed to the cause of state building; transparent and open with the people and the trust was returned. He exhibited good self-discipline and moral rectitude.

- Institutional Capacity: Incipient capacity, which he supported and engaged. He had a realistic assessment of the institutional capacity of the civil service.

- Policy thrust: Emergent at the time, but focused and directed at selected programmes such as road networks, education etc. These had great developmental implications. He had a strong vision and mission for the improvement of the civil service and the society.

- Participation of the Bureaucracy: Highly engaged in the process of governance.

- Perception of the Bureaucracy: Regarded the bureaucracy as highly effective and made use of them

- Perception of the Governor by the bureaucracy: Participatory and trustworthy. He enforces discipline, rules and regulation.

\section{GOVERNOR GVM2 (deceased) 1975-1977}

Unlike his immediate predecessor who spent nine years in office, GVM2 spent only two years. He came into governance at the height of the Nigerian oil-boom that raised the standard of living and the consequent rise in the demand for luxury goods especially cars. Lagos State was fast developing the reputation of a flourishing commercial center and a land of opportunities and many people moved to the area. The affluence of this period meant that some families living in Lagos owned more than one car. This coupled with insufficient mass transit and infrastructure for all means of transportation led to incessant traffic disorder. Shodipe (1997: 40) succinctly describes this period, "It was a nightmarish exercise. Traffic congestion widened everyday as more people arrived in Lagos metropolis. The subsisting affluence of the residents, which had been fuelled by the riches of the petrol-dollar, was now heightened the more in a spendthrift consumptive flowering where Lagosians engaged in competitive ostentations, acquiring tinsels, cars, new homes and the latest organza fabric. Everywhere was riddled with traffic paralysis as Lagosians flaunted their wealth in vehicular ubiquity, cruising around in leisurely license".

This period also coincided with the hosting of the Festival of Arts and Culture (FESTAC) by the Nigerian Government in 1977 in Lagos. For the success of the Festival, a desperate measure had to be taken, as organizers expected to receive visitors from all over the world. In order to find a solution to the embarrassing traffic jam in Lagos, GVM2 promulgated the Road Traffic Edict that controls the movement of vehicles. Cars with even-number plates could take the roads on Mondays, Wednesdays, and Fridays; odd-number plated cars were to take Tuesday, Thursday and Saturday. All the cars had free access on Sunday. Vehi-

\footnotetext{
35 "Even with nine years of governance, he had not acquired wealth. He had an old Citroën and a Volkswagen. He had no house to call his own" (Shopide, 1997:33). He was transparent and he promoted accountability and careful administration of public funds.
} 
cles belonging to the emergency services like ambulance, fire brigade, armed forces, etc. were given right of entry at all times. The success of this programme got the GVM2 an accolade from the President. However, due to lack of effective enforcement and inadequate sources of mass transportation the effectiveness of this edict was soon exhausted, although it was only abrogated fifteen years after. This edict solved the immediate problem of traffic congestion of Lagos metropolis, while it was not a permanent solution. Lagos metropolis traffic is still horrendous.

One of the major policy thrusts of this Governor was in the area of education. In 1976, the Universal Free Primary Education Scheme (UPE) was launched. This gave opportunity to thousands of children to be exposed to formal education. In Table 4.2, the number of primary schools increased from 544 in 1975, to 598 and 624 in 1976 and 1977 respectively. The number of pupils rose from 355,645 in 1975, to 388,429 and 411,416 in 1976 and 1977 respectively. In 1977, the government took over the entire secondary school system from the private school owners and the missionaries in order to enforce uniform standards in the schools. According to the government, "there were glaring differences in the quality of education in these three sectors." The religious missionary and the government were trying to ensure high quality in their schools, but many of the private ones were more interested in their exorbitant fees compared to the standard of teaching.

This take over led to an enormous financial and managerial burden on the Lagos State Government. In the 1976/1977 financial year, the recurrent expenditure was 182.4 million $\mathrm{Naira}^{36}$, with an increase of $25.8 \%$ in the $1977 / 78$ financial year to 229.5 million Naira. Over $78 \%$ of this amount was earmarked for public services with education taking the lion's share at 100.4 million Naira or $43.7 \%$. This also led to quantitative increase in the number of pupils under the umbrella of the state government. Although there was a decrease in the number of secondary schools, because of the take over, the pupil-teacher ratio in secondary schools rose. In Table 4.2 we note the ratio of teacher/students rose from ratio 1: 27 in 1975 to 1:34 in 1976. This quantitative expansion had an adverse effect on the whole educational system. The quality of educational services declined in view of the high students/teachers ratio, an outcome that was at variance with the original intention of the government in taking over the schools. The lack of accurate assessments in the decision-making process of government about an effective way to standardize the educational sector led to the government taking over all secondary schools. This singular action of government continued to have an adverse effect on the educational sector for a very long time because subsequent governments inherited this policy.

\footnotetext{
${ }^{36}$ The exchange rate between the US\$ and the Nigerian Naira between 1995-2003 is on page 23. However, it should be noted the US\$ and the Nigerian Naira in the late 1970s were almost at par.
} 
Table 4.2: Lagos State: Growth of Secondary Education between 1967-1981

\begin{tabular}{|l|c|c|c|c|c|c|}
\hline Year & $\begin{array}{c}\text { No. of } \\
\text { Schools }\end{array}$ & $\begin{array}{c}\text { Annual } \\
\text { Increase }\end{array}$ & $\begin{array}{c}\text { No. of } \\
\text { Pupils }\end{array}$ & \% Increase & \multicolumn{2}{c|}{ Pupils } \\
\hline & & & & & Per \\
School & Teacher \\
\hline 1967 & 87 & - & 16,879 & - & 194 & 18.8 \\
1968 & 82 & 5 & 17,296 & 25 & 211 & 17.1 \\
1969 & 84 & 2 & 20,073 & 16.1 & 234 & 19.3 \\
1970 & 91 & 7 & 25,479 & 26.9 & 280 & 21.2 \\
1971 & 90 & 1 & 29,357 & 15.2 & 326 & 22.9 \\
1972 & 97 & 7 & 33,898 & 15.5 & 350 & 22.5 \\
1973 & 105 & 8 & 37,751 & 11.4 & 360 & 19.4 \\
1974 & 110 & 5 & 51,265 & 35.8 & 466 & 21.5 \\
1975 & 115 & 5 & 61,704 & 20.4 & 536 & 27.0 \\
1976 & 94 & 21 & 75,179 & 21.8 & 799 & 34.6 \\
1977 & 79 & 15 & 81,539 & 8.5 & 1032 & 25.8 \\
1978 & 79 & 0 & 89,584 & 9.9 & 1134 & 24.7 \\
1979 & 104 & 25 & 107,835 & 20.4 & 1033 & 26.5 \\
1980 & 223 & 119 & 163,862 & 52 & 735 & 22.4 \\
1981 & 285 & 62 & 197,305 & 20.4 & 692 & 25.6 \\
\hline
\end{tabular}

Source: Ministry of Education as presented by Olowu 1990, pg. 75

Bounded rationality ${ }^{37}$ is well illustrated in the take-over of secondary schools by the state government. First, the government had no accurate data on the eventual number of pupils that would seek enrolment. This was a path not taken before. Secondly, the cost could not be fully anticipated because complete information was not available to government planners.

Another important area of concern is waste management, which continues to challenge successive governments. The government tried to improve on the collection and disposal of solid wastes in the metropolis to address the state's environmental and sanitation issues. The sum of 47.6 million Naira (18.5\% of the capital expenditure) was appropriated to the local governments who were then in charge of refuse disposal. These funds built two giant incinerators, but unfortunately, these incinerators were never put to adequate usage due to maintenance and repairs difficulties. Nevertheless, the tenure of this Governor was noted for the drive towards the elimination of the outdated pail system of night soil disposal in the metropolis. The government took the initiative, provided about 1,000 households with modern toilet systems and encouraged property owners to do away "with the archaic mode of solid waste disposal".

In the health sector GVM2 established the Hospital Management Board, which coordinates and standardizes the health administration of all the state's hospitals. This Board is in charge of employment, transfer, promotions and disciple of the medical personnel. In view of the importance of the Board to health administration, it endures as an important state institution. In governmental administration, this regime would be remembered for its concerted efforts in developing the permanent Lagos State Government Secretariat at the state capital, Ikeja. Before then, government operations and ministries were scattered all over the state making coordination and communication between the different agencies difficult and unsynchronized. The planning and preparatory work for the state secretariat that became the administrative nerve center of the Lagos State Government occurred during this regime.

\footnotetext{
${ }^{37}$ Bounded rationality is what Simon (1957) refers to as when the degree of rationality in decision-making is influenced by perceived, imagined or unanticipated demands both inside and outside organizations.
} 


\section{Summing Up on GVM2: Factors Influencing Governance and Leadership}

GVM2 focused more on social delivery programmes and far less on economic activities that would generate money for the state. In the 1977/78 financial year, out of the 229.5 million Naira earmarked for recurrent expenditure, $78 \%$ was allocated to public services: education took 100.4 million Naira or $43.7 \%$, health sector had 35.7 million Naira or $15.3 \%$ and works and planning services competed for 26 million Naira of the total recurrent expenditure. The complete take over of all secondary schools was at a great financial and managerial burden for the state. The following is a summary assessment of the Governor:

- Personal qualities: He showed a high sense of transparency, integrity and good moral character.

- Institutional Capacity: He did not have a realistic assessment of the institutional capacity of the Civil service. The take-over of private and missionary secondary schools turned out to be a mistake.

- Policy thrust: Although he instituted people-oriented policies that could positively affect the welfare of the people, the decisions lacked good sense of judgment and instinctive caution.

- Participation of the Bureaucracy: He did not make effective use of the bureaucracy. The bureaucracy will work according to how much it could be challenged.

- Perception of the Governor by the bureaucracy: He was people-oriented and instituted policies that would affect the well being of the people.

\section{GOVERNOR GVM3 1977-1978}

The attitudes and perceptions of the Governors to the problems they met always influenced the key plans, programmes and policies they initiated. In the interview with Governor GVM3, he said,

"I knew there were problems in Lagos having been a member of the National Council of States, and also having lived in the state. However, I believe governance is continuous and it is not necessary to develop a new blue-print".

It is no surprise therefore that the administration did not embark on new programmes that made lasting impact.

One of the areas of interest to GVM3 was environmental sanitation. On assumption of duties, the mountainous piles of garbage appalled him; the huge incineration plants purchased by his immediate predecessor GVM2 (deceased) were hardly used due to maintenance and repair problems. Reflecting, GVM3 said,

"Refuse were mounting everywhere. The refuse were not being properly disposed off. I decided that the government has to take some drastic measures."

In 1977, GVM3 established the Waste Disposal Board, in an attempt to "erase the unfavourable reputation of Lagos as the dirtiest city in the world" (Lagos State Ministry of Information). With the inauguration of the Waste Disposal Board, the responsibility of waste disposal was excised from the local governments. This Board was to oversee the effective and efficient collection and disposal of refuse in the state. He contracted the services of Messr Powell Duffryn of Great Britain for 5.67million Naira to provide consultancy and project management to the newly inaugurated Board. Vehicles and equipment were made available to the Board, 70 mammoth vehicles to 27 Dinosaur refuse vehicles. The Board also bought 20 large tippers and 6 mechanical shovels among other equipments. GVM3 got companies and the citizenry concerned on the need to develop a healthy environment. He also reaffirmed the 
full provision of the Sanitation Edict in order to demonstrate his resolve to rid the state of street hawking ${ }^{38}$, filth and dirt.

Unfortunately, up to the time of writing this dissertation in 2005, Lagos State continues to grapple with the problems of street hawking, waste collection and disposal. This represents both a major policy and institutional failure. Taking over waste management from the local governments was a mistake; it would have been better to enhance the institutional capacity of the local governments to continue this work as they are closer to the grassroots and would know how to dispose of the solid waste more effectively.

Another formidable problem for GVM3 was in the educational sector. He inherited the Universal Primary Education (UPE) scheme. In 1977, the number of Primary schools in Lagos State rose to 624 with 411,416 pupils. The ratio of teachers/students ratio was 1:26 at this time. The government had stopped charging tuition and other fees, while the parents were responsible for their children's books and other materials. However, the effectiveness of the UPE was put into question in view of the lack of teaching aids and materials, shortage of teachers and lack of adequate accommodation. In the secondary school sector, the story was similar. The take over of all secondary schools by his predecessor has started to draw heavily on the recurrent expenditure of government. The schools did not have enough classrooms to accommodate the students. An emergency remedy had to be instituted and the shifts system was introduced ${ }^{39}$.

According to Olowu, (1990:75), "by 1978 forty, or over half of the 79 secondary schools ran morning and afternoon shifts and many primary schools ran three shifts." The quality of education started to decline because there were no longer quality interaction time between the teachers and the students. Summarizing, Shodipe, (1997:62), "The summative portrait of all this was signified in the awful performance of the students at the School Certificate Examination. More than half of the students could not even scale the average pass mark. Soon, the students turned into outright examination fraud, conniving with West African Examinations Council (WAEC) officials to smuggle written answers into the examination halls. Many students from different secondary schools were dragged before a Special Tribunal on Examination fraud."

To confront this problem, GVM3 set up an Advisory Board. One of the Board's recommendations to rescue the educational sector was for the government to increase funding for capital and recurrent expenditures. The state solicited for assistance of the Federal Government and this led to the provision of 2million Naira, which had the effect of a drop of water in an ocean. However, before he could mobilize more funds and proffer other solutions, his oneyear term as Governor was over.

At the technical education level, the State would remember him for the Lagos State College of Science and Technology (LACOSTECH) now called Lagos State Polytechnic, a project conceived during GVM1, but established during this administration. One of the aims of the college was to promote research and development in the area of trade and technological services of the state. To increase the number of health workers available to the teeming populace, GVM3 established the first school for Health Technology under the Ministry of Health during this period. In the other areas, no major landmark was recorded during this period.

\section{Summing Up on GVM3: Factors Influencing Governance and Leadership}

In the interview with GVM3, he remarked,

\footnotetext{
${ }^{38}$ People selling things on the roads contribute to the problem of urban waste disposal as buyers indiscriminately throw wrappers of things bought.

${ }^{39}$ The "shift" system meant that the school system was modelled on the factory system. Pupils could not fit into available classrooms all at once. Afternoon classes were added to the regular morning classes.
} 
"Military governance is an aberration. I came to Lagos State on a military posting. There was no need for manifesto."

He largely continued the programmes inherited from his predecessor including the Odd and Even Number Vehicle Edict meant to contain the chaotic traffic situation in Lagos. There were no new developmental initiatives plans by this regime. Since the regime did not articulate its own vision, it did not to focus on any particular programme. The following is a summary assessment of the Governor:

- Personal qualities: He enforced discipline, rules and regulation.

- Institutional Capacity: He knew the institutional capacity of the Civil service, but only used them to the extent of his own vision, which was quite limited.

- Policy thrust: He did not have a strong vision and mission for the improvement of the Civil service and the society. His period of office was short.

- Participation of the Bureaucracy: He did not make effective use of the bureaucracy; the Civil service only works in line with the direction given to it by its leaders.

- Perception of the Bureaucracy: He regarded the bureaucracy highly.

- Perception of the Governor by the bureaucracy: He enforced discipline, rules and regulation.

\section{GOVERNOR GVM4 1978-1979}

Governor GVM4 specifically said,

"Although one may have a major programme, governance is basically routine".

Governor GVM4 came into governance at the period when the Federal Military Government promised the populace that it would disengage from politics. In the words of GVM4,

"the major programme we had was to prepare Lagos State for civilian rule. I was to get a democratically elected government into place. We continue with the basic routines of governance like road rehabilitation, water supply and the execution of on-going projects."

This government did not initiate any new capital project but rather continued with on-going programmes in the various areas of public service deliveries.

Measured against his stated mandate, GVM4 appears to have succeeded in steering Lagos State to a successful transition to civilian rule. He conducted himself in a professional way so that no sector of the society or the political parties accused him of partisanship or favouritism ${ }^{40}$. Describing the role of GVM4 during this period, Shodipe, (1997:79) observed "For 15 days during the display of voters register which began in Lagos on October 5, GVM4 dashed across the State in laborious activism. He talked to the voters in casual informality, encourage their civic vigilance. He scrutinised the performance of the electoral officers, insisted on a firm adherence to propriety. It was the same articulated candour that the military administrator brought to bear throughout the different levels of election which began at the wards in gradual thoroughness, moving to the councils, the State Assembly, the Senatorial districts, the National Assembly and the gubernatorial culmination which affirmed the electoral victory of GVC5 as the first civilian Governor of the state." In other words, the Governor took his assignment very seriously.

However, the same thing cannot be said about him in other fundamental governance issues. His regime coincided with an acute water shortage to which he was incapable of proffering any solution. This period also witnessed the doctors' strike, a protest against the deterioration of health facilities and lack of drugs. The perennial problem of street hawking resurfaced and the "Illegal Markets and Street Trading (prohibition) Edict, 1978 was re-enacted by the

\footnotetext{
${ }^{40}$ In a country with complex ethnic and religious mix, retort to tribal and religious bias is a common tool by aggrieved parties.
} 
government. However, the implementation was not effective or successful. The "Taxi cab (prohibition of Operation without Meter) Edict" was unpopular and soon became moribund. These types of laws are common but fail repeatedly in part due to poor enforcement and fundamentally because they lack legitimacy. A military ruler is not elected and has little interest in sustaining a decree beyond his own tenure. More importantly because these decrees lack constitutional backup, they are not institutionalised and tend to expire with the exit of the military Governor that established it. An institution (a law providing incentive to good behaviour) is sustained because the public sees the benefit and are constrained to obey such laws. These conditions are often missing in military decrees.

In the area of education, the regime continued the established three-shift school system because of persistent shortage of classrooms. Either students attended morning, afternoon or evening sessions. This practice continued to erode the standard of education as many students had only three teaching hours per day. In spite of this, this administration did not establish any new schools. By 1978, there were 89,584 students in secondary schools and student-teacher ratio was 1:25. Subsequently, a sporadic expansion of private and illegal schools charging exorbitant fees emerged. The Governor also dissolved the Teaching Service Commission and the Schools Management Board without any replacement. A chaotic school administration ensued due to inadequate supervision of schools.

Aside from the successful transition programme, this regime cannot be credited with any governmental attainment. According to DSI however, "a Governor that does a routine job is not visionary. But those that come to make changes and institute landmark programme that will affect the lives of the people are visionary. The ability of the government to effectively implement, monitor its programmes, and keep its executive in focus is very important. The Governor plays a major role. If he allows things to slip out of his hands, he will not be able to achieve his goals. Lagos is a complex cosmopolitan state". Another factor against GVM3 and GVM4 was that they had relatively short tenure, both spent only one year as Governors of Lagos State, which was not long enough to make any definite impact.

\section{Summing Up on GVM4: Factors Influencing Governance and Leadership}

Unlike his immediate predecessor, GVM4 came into governance with only one programme in mind

"have elections and hand over to a civil Government, democratically elected."

If one is to judge this administration only in view of this programme, GVM4 did well. However, governance is multi-faceted; he did not have any landmark capital projects and no enduring policy. The following is a summary assessment of the Governor:

- Personal qualities: He exhibited good self-discipline and moral rectitude. Institutional Capacity: He knew the institutional capacity of the Civil service, but only used them to the extent of his own programme.

- Policy thrust: He did not have a strong vision and mission for the improvement of the Civil service and the society.

- Participation of the Bureaucracy: He made effective use of the public servants during the time of election, and they performed well.

- Perception of the Bureaucracy: He regarded the bureaucracy highly.

- Perception of the Governor by the bureaucracy: He enforced discipline, rules and regulation.

\section{GOVERNOR GVC5 1979-1983}

Lagos State has had a long history of Western-styled education with the first primary school built in Badagry in 1843, and a secondary school in 1859 by the Christian Missionary Society 
(CMS). In view of the fact that it was by that time a part of the Old Western Region, the Lagos colony adopted the Universal Primary Education policy (UPE) in 1957. It was a Herculean task however, for the newly-formed state to match the quality of educational services in the Old Western Region. One of the problems of Lagos State is its peculiar position as a fastgrowing cosmopolitan city and as the Federal capital before the latter relocated to Abuja in 1991. It attracted bureaucrats, entrepreneurs, employers and employees, and job seekers. First, the existence of UPE led to an astronomical number of pupils in both the primary and secondary schools with its attendant problems.

Second, planning for education in Lagos State was hazardous at best. There was a big gap between the actual population and the official population projection; the projected population for 1979 was 2.4 million, while the actual population of the state in 1978 was about 4.3million (Olowu 1990). Lack of appropriate socio-economic data hinders adequate planning. Third, as was related earlier in 1977, in an attempt to synchronize the quality of education in the state, the government took over the responsibility of the entire secondary school system from their private and religious owners and merged them with the state-owned schools. Over the years, these factors led to lack of adequate student facilities - classrooms were overcrowded and bursting at the seams. This made the introduction of the ubiquitous shift system necessary. Coupled with this is an incapable school administration with inadequate supervision. A majority of the schools did not have enough qualified teachers and sufficient teaching facilities.

By the time GVC5 assumed duty in Lagos State, the standard of education has reached an alarming state of deterioration. According to Shodipe, (1997:86), the Education Committee set up by the democratically elected Party (United Party Of Nigeria) found out that "the institutions of learning were ill-administered, hindered by largely congested classrooms where pupils were subjected to the primitive crudity of morning, afternoon and evening sessions. In this sandwich procedure, no knowledge was imparted as pupils were hurried through instructions with the mechanical reflex of a herd mentality. The pupils were rushed out and rushed in amid a notional artificiality." Although Lagos State came first in many of the social and economic indicators, it came fifth in enrolment according to Table 4.3, a depiction of the relationship between population and primary school enrolment. However, the accuracy of this population projection has been questioned. Nevertheless, if one uses 4.3 million as the actual 1978 population, then the probability of the state having the 12th position is very high, assuming that the other states' actual population does not differ much from the projection. 
Table 4.3: Nigeria: Primary School Enrolment and State Population, 1979/1980. ${ }^{41}$

\begin{tabular}{|c|c|c|}
\hline States & $\begin{array}{c}\text { Population } 1979 \\
\text { (Million) }\end{array}$ & $\begin{array}{c}\text { Primary school Enrolment } \\
1979 / 1980 \\
\text { '000s\% of population } \\
\text { (and rank order) }\end{array}$ \\
\hline $\begin{array}{l}\text { Benue } \\
\text { Bendel } \\
\text { Kwara } \\
\text { Rivers } \\
\text { Lagos } \\
\text { Imo } \\
\text { Anambra } \\
\text { Niger } \\
\text { Plateau } \\
\text { Cross-River } \\
\text { Oyo } \\
\text { Borno } \\
\text { Ogun } \\
\text { Kaduna } \\
\text { Ondo } \\
\text { Gongola } \\
\text { Bauchi } \\
\text { Kano } \\
\text { Sokoto }\end{array}$ & $\begin{array}{l}3,591 \\
3,641 \\
2,537 \\
2,545 \\
2,396 \\
5,434 \\
5,321 \\
1,767 \\
2,998 \\
5,146 \\
7,706 \\
4,435 \\
2,295 \\
6,063 \\
4,038 \\
3,854 \\
3,597 \\
8,544 \\
6,715\end{array}$ & $\begin{array}{cc}24 & (1) \\
23 & (2) \\
23 & (2) \\
20 & (4) \\
19 & (5) \\
19 & (5) \\
18 & (7) \\
18 & (7) \\
18 & (7) \\
17 & (10) \\
17 & (10) \\
16 & (12) \\
15 & (13) \\
14 & (14) \\
12 & (15) \\
12 & (15) \\
11 & (17) \\
10 & (18) \\
6 & (19)\end{array}$ \\
\hline Total/Average & 82,621 & 15 \\
\hline
\end{tabular}

Source: Adapted from Dele Olowu 1990 Lagos State: Governance, Society and Economy P. 29

Governor GVC5 came into power during this period of educational down-turn in Lagos State. Responding to whether he anticipated the problem, he said,

"Yes. I anticipated the magnitude of the problems I encountered when I took office. I said so in my acceptance speech after my inauguration as Governor of Lagos State. On that day, I also declared my determination to solve the problems during my tenure".

He had clarity of goals and vision, along with a strong commitment to achieve development for Lagos State. He said further,

"I initiated several plans and programmes. I appointed planning committees after my party nominated me. The committees produced blueprints on the subjects assigned to them. The blueprints were presented to the State Executive Council of the Lagos State Government for adoption and implementation".

This Governor is noted for his four cardinal programmes: free education at all levels, free health care for all citizens, full employment, integrated rural development. Added to these were public transportation, affordable low cost housing, and road construction. In an extract from his budget, tagged "The New Order Budget", to the State Assembly on Friday, December 7, 1979, Governor GVC5 said inter alia thus:

"We came into office with well-prepared, clear-cut and specific programmes. These programmes are deliberately radical, ambitious, challenging, unprecedented, and above all, progressive. We have come to change the direction of public policy. We

\footnotetext{
${ }^{41}$ According to Olowu (1990:72) "By the unrealistic and conservative estimates of 1979 population projection, 19 per cent of the State's total population is enrolled in the primary school system. In actual fact, this is an exaggerated proportion of the actual once it is accepted that, .... the 1978 population of the State was 4.3 million ( as against the official 1979 population projection of 2.4 million)”.
} 
have come to change the emphasis of governance from the direction and protection of the privileged persons to that of caring for the welfare and the greatest good of the greatest number.

Shodipe, (1997:86) commenting on the public policy of Governor GVC5, states: "The predication here was to appraise the summative condition of the State by sifting through the cumulative accretions of existing policies, examining realities, perceiving the failings of governance, devising new solutions, envisaging new challenges, inventive in various pursuits." The various committees created credible blue prints that developed into good and sustainable plans, programmes and policies.

Governor GVC5 came into governance with a strong philosophy and personal conviction that the difference between the developing and the developed nations is education. $\mathrm{He}$ submits,

"No nation can ever become great or realized its economic potentialities if she treats education as the privilege of a few rather than the right of every citizen."

He felt committed to education and one of his greatest achievements is in the area of free and universal education at all levels. This period saw a quantitative improvement in the overall educational system of the State. Box 4.1 captures the Governors' educational philosophy.

Box 4.1: Background to Governor's GVC5 Educational Philosophy ${ }^{42}$

If I were to describe in one word what accounts for the difference between the developed nations and the under developed and developing countries of the world, I would say "education". For the natural resources of the United States, of the United Kingdom, the USSR, Japan, France, or Germany are not greater or better than those of India, Nigeria, Zaire, Indonesia, Kenya or Senegal. Indeed, as a group, the underdeveloped nations are blessed with richer natural resources than the developed ones. But each of the developed nations has by far a higher level of education than each of the underdeveloped. For example, universal primary school and junior high school became compulsory for all Japanese children up to the age of 15 in 1947. Indeed, it is common knowledge that the rise of Japan to the challenge of attaining the position of world power was due more to the importance she attached to education than anything else. It is therefore my conviction that the key to the rapid development of Nigeria and other undeveloped countries of the world is a radical approach to education at all levels. I submit that no nation can ever become great or realize its economic potentialities if she treats education as the privilege of few rather than the right of every citizen

Source: Alhaji Lateef Jakande: The Educational Reformer- a biography by Israel Opeolu Osokoya 1995 P. 36

Initially, many people saw his programmes as ambitious and unattainable because he did not have infrastructural facilities (classrooms) to cope with his policy of free education. In order to surmount the problem of classrooms, by October 1980, he targeted the construction of 10,126 classrooms (4,984 primary, 5,142 secondary). These were purely functional classrooms created without regard to elegance or aesthetics, which led critics to call these classrooms "chicken houses". According to Olowu, (1990:72) "education has been one of the greatest revenue-consuming services in Lagos State, and this is particularly so with respect to recurrent as compared to capital expenditure". During GVC5's tenure, the highest capital expenditure was $21 \%$ during the $1980 / 81$ fiscal year. The relatively small amount of money allocated to capital expenditure was evident in the poor quality of the classrooms. The conges-

\footnotetext{
${ }^{42}$ This educational philosophy of GVC5 was quoted in his autobiography written by Israel Opeolu Osokoya in 1995
} 
tion in the classrooms, especially in the metropolis, also contributed to deplorable environmental conditions for schools.

However, as depicted in Table 4.2 (above) and Table 4.4 (below), from 1979-81, his regime recorded the highest pupil enrolments in both the Secondary and Primary schools. The percentage increase in the number of secondary enrolments from $1979(20 \%)$ to $1980(50 \%)$ and $1981(20 \%)$ were astronomical. This was due to the abolition of common entrance examination from the primary school into secondary that gave all children equal opportunity to enter the secondary schools. At the tertiary level, he established the Lagos State University (LASU) in 1983, and upgraded the Teacher's College to a State College of Education and relocated it to a bigger site at Oto-Ijanikin.

Table 4.4: Lagos State: Growth of Primary School Education, 1967-1981

\begin{tabular}{|c|c|c|c|c|c|c|}
\hline Year & $\begin{array}{c}\text { Number of } \\
\text { Schools }\end{array}$ & $\begin{array}{c}\text { Annual } \\
\text { Increase }\end{array}$ & $\begin{array}{c}\text { Number of } \\
\text { Pupils }\end{array}$ & \% Increase & Pupils \\
\hline & & & & & $\begin{array}{c}\text { Per } \\
\text { School }\end{array}$ & Teacher \\
\hline 1967 & 442 & - & & & 442.7 & 30.3 \\
1968 & 446 & 195,655 & - & 464.4 & 32.0 \\
1969 & 450 & 4 & 207,126 & 5.9 & 514.6 & 32.4 \\
1970 & 453 & 231,560 & 11.8 & 524.4 & 32.7 \\
1971 & 456 & 3 & 237,560 & 2.6 & 528.4 & 33.1 \\
1972 & 472 & 16 & 270,533 & 12.3 & 573.1 & 34.1 \\
1973 & 471 & 1 & 309,455 & 14.4 & 657.0 & 33.6 \\
1974 & 524 & 318,270 & 2.9 & 607.3 & 30.0 \\
1975 & 53 & 355,645 & 11.7 & 653.8 & 31.3 \\
1976 & 544 & 20 & 388,429 & 9.2 & 649.5 & 33.9 \\
1977 & 598 & 54 & 411,416 & 5.6 & 659.3 & 36.9 \\
1978 & 624 & 28 & 434,543 & 5.6 & 719.4 & 37.5 \\
1980 & 605 & 19 & 477,371 & 9.8 & 658.4 & 32.1 \\
1981 & 725 & 120 & 527,649 & 10.5 & 649.8 & 33.9 \\
\hline
\end{tabular}

Source: Ministry of Education as presented by Olowu 1990, p. 74

According to PSS II, "GVC5's vision was to make education available to everybody. His major policy direction was towards education." Reminiscing, RPSIII and PSSIII both believed that GVC5 had a mission and a programme for education, which he followed religiously. In order to achieve his mission of "education for all", he abolished fee payment in both primary and secondary schools in the state, although this led to a great financial burden on the state. GVC5 was also noted for his footprints in the areas of free health services, housing, and mobilization of financial and human resources. According to DSI "GVM1 and GVC5 were noted for their efforts in education, grass root mobilization, physical development and urban renewal"

GVC5 also left his footstep in other areas of social delivery. The health sector was one of the priorities of this administration. He abolished fee payment at all government owned hospitals and health centers. In line with his vision for full employment, the number of Ministries were increased to 13, 10 Departments and 52 Parastatals ${ }^{43}$. In 1980, the number of the local governments increased in order to bring development to the grassroots and encourage greater participation of the populace. This increase created 458,563 jobs in institutional agen-

\footnotetext{
${ }^{43}$ The Ministerial and parastatals structure of the Lagos State Government in 1968 were 7 Ministries, 4 parastatals and 16 local Governments. By 1977 the numbers were 12 Ministries, 8 parastatals and 8 local Governments (Olowu 1990: 49)
} 
cies. The government also focused on integrated rural development through the provision of public services deliveries such as roads, rural electrification, potable water, health and educational facilities in order to stem the rural migration to the urban areas. The government built 23,352 housing units, 4,800 of which were for medium-income workers and the remaining for low-income earners.

The administration also introduced new land policy and a state regional masterplan to regulate and encourage planned growth of the metropolis. In the area of transportation, the major landmark was the conception of the metro line project. It planned a mass transit system to move about one million people daily. This would have been a major solution to the perennial problems of congested traffic in Lagos metropolis, but his successor a military Governor terminated the project. In order to enhance timely dispensation of justice, nine new high courts were established and 54 customary courts were established throughout the State. The Lagos State House of Assembly was also built during his tenure.

These laudable works were possible because of the active participation of the bureaucracy and his cabinet. According to GVC5,

"I believe that, as leader of the state of Lagos, I had a clear vision to transform the state, to raise the living standards of the people and to ensure for their happiness, welfare, security and freedom from any form of oppression. That was my mission and I accomplished it with reasonable satisfaction. I had an excellent relationship with my staff in the civil service and my political colleagues in government".

GVC5 stood out in the Second Republic as an honest, hard working Governor interested in bringing succour to the people of Lagos State. These attributes made him stand out compared to the majority of the Second Republic's politicians, especially those at the federal Level who were revelling in "unrestrained debauchery of a perverted democracy". According to Shodipe, (1997:103), "The politicians of the Second Republic exuded in graft and loose bacchanalian excesses, unmindful of public sensitivity, rash and vindictive, imperial, disdainful of critical containment, wrapped in the full grandeur of power." This political environment gave the military an opportunity to return to power through a coup d'état in December 1983.

\section{Summing Up on GVC5: Factors Influencing Governance and Leadership}

He was the first democratically elected Governor of the state. He won the majority of the votes and therefore had the support of the populace. When he ran for office the second term in 1983, GVC5 was

"rewarded with $95 \%$ of the total votes cast in the election".

$\mathrm{He}$ came into governance with a manifesto and initiated several plans and programmes. $\mathrm{He}$ was very focused, industrious and knowledgeable about the workings of the civil service. The following is a summary assessment of the Governor:

- Personal qualities: He exhibited good self-discipline and moral rectitude. He also enforced discipline, rules and regulation. He demonstrated a high sense of transparency and integrity.

- Institutional Capacity: He had a realistic assessment of the institutional capacity of the civil service and he used it very effectively

- Policy thrust: He had a strong vision and mission for the improvement of the civil service and the society. He instituted policies that positively affected the welfare of the people. He was regarded as a great achiever and he dared to make changes.

- Participation of the Bureaucracy: He had the ability to lead and inspire the staff through hard work, brilliance and uprightness.

- Perception of the Bureaucracy: He regarded the bureaucracy highly.

- Perception of the Governor by the bureaucracy: He was participatory. He had a good moral character that the people wanted to emulate. 


\section{GOVERNOR GVM6 (deceased) 1984-1986}

One of the documents from the Lagos State Ministry of Information reads, on resumption of duty GVM6 "immediately instituted high-powered committees to undertake a detailed study and adequacy or otherwise of strategies, structure and resources available for the implementation with a view to evolving policies and programmes consistent with the economic realities of the period". The committees were mandated to "carefully consider all options and undertake possible widest consultations with all the segments of the society for inputs".

All the informants were unequivocal about his success, despite being at the helm of affairs for only two and a half years. Commenting on the tenure of GVM6, RPSI said, "His target was to build the most beautiful and cleanest state in the federation. He wanted things to be done very well. His emphasis was for the entire Lagos State. He would go unannounced to survey works that were being done during the night. He worked $24 \mathrm{hrs}$ a day. He established public complaint centers in all the local governments." In the interviewee's opinion, GVM6 had finesse. Supporting this, DSI believed that "GVM6 introduced quality to government in all ramifications."

In the area of education, GVC5 emphasis was more quantitative than previous leaders in the sense that he wanted free education for all. GVM6 went further to improve on the quality of education, although he continued with the free education policy of his predecessor. GVM6 reversed some of GVC5's policies in order to improve the quality of education. One step was to abolish mass promotion between classes and the automatic admission into secondary schools. Primary school students now had to pass the First School Leaving Certificate Examination in addition to obtaining $40 \%$ in class work before admission into the secondary schools. Automatic promotion ensured that disadvantaged children were not left behind, however, the negative consequence was that it could discourage diligence and studiousness on the part of the pupils.

He also improved on the learning environment by providing 998 blocks housing 16,899 prototype classrooms used to replace the classrooms built by GVC5. Some of the new classrooms were equipped with science laboratories, libraries and workshops. The classrooms were also equipped with 200,000 pieces of school furniture and had laboratory fixtures installed. Science and technical colleges in each of the five administrative divisions of the state were created to provide the needed work force for the industries. To encourage communities to participate in the funding of education, he initiated the Education Endowment Fund with 13.5million Naira in December 1985. According to RPSI, "as time progressed, GVM6 built on the system. He built permanent structure. His major policy direction was towards quality".

In the area of housing, he provided 4000 quality prototype low- and medium-cost housing designs in five locations. He also raised the standards and upgraded the low-cost housing estates in the metropolis. Acknowledging the work of his predecessor, GVM7 said,

"GVM6 improved on the work of GVC5. GVM6 reviewed the existing housing policy and tried to introduce quality."

He also continued free healthcare delivery in all the state government's health institutions at the cost of $73,109,224$ Naira or $15.3 \%$ of the total recurrent expenditure in 1984 . The main thrust of health care was the hygienic and sanitary environment with the strengthening of the leprosy programme and malaria control programme. He undertook a comprehensive environmental upgrading exercise. He started the beautification of the state by establishing the Environmental Sanitation Task Force to curb the menace of street trading and to maintain a healthy environment. Side parks and roundabouts were improved and open areas for sports and youth activities were preserved. The government instituted campaign against illegal structures that blocked drainages or hindered traffic. He declared "Sanitation Observance Day" for all's workers and later for whole communities to join in the cleaning exercise. 
A test of his moral rectitude came when the government officials issued an ultimatum to the parents of GVM6 to remove an illegal structure they had in front of their house. According to Shodipe (1997:112), "Perhaps in an instructive instance of principled governance, GVM6's demolition crew had sent a seven-day ultimatum to the parents of the military Governor. They were directed to remove the extensions to their family residence at Ikorodu. The Governor's parents complied within three days. An extension that had served as the shop of the Governor's mother had to be destroyed. This action spurred others in Ikorodu who had resisted the exercise into compliance." This singular action showed that he was "blind to privilege and power, indifferent to the vaunted status of the untouchables, impartial in its uniform, cleansing frenzy".

Reminiscing, RPSI said that the "state was gradually becoming a beautiful state. There were competitions amongst the local governments in order to know the cleanest. Government agencies in charge of building were encouraged to build houses with good aesthetic finishing. There were developments of public conveniences, and the roundabouts were made beautiful by the planting of the gardens. GVM6 was seen as being fair, and had the interest of the people at heart. He showed leadership by example that he will not flout the law, so he expects the populace to comply too."

Another major policy thrust of this administration was the construction of strategic inter-communal roads. In 1984, 215 roads were constructed or rehabilitated. In 1985, 208 roads covering 106 kilometers through urban and rural areas were resurfaced. In the government's commercial and residential areas, 47.05 kilometers of roads were constructed costing 45.79 million Naira. In his contribution, PSSII said, "During the time of GVM6 in $1984-86$, he opened up some new roads although the ones he did not complete were forestalled by subsequent policy of government" Adding to this, RPSI opines that GVM6 had a good policy on roads because he ensured that both federal and states roads and drainages were constantly repaired. However, a major policy blunder in transportation was made when the GVC5's carefully planned metro-line project was abandoned without an alternative solution to solve the metropolis's perennial traffic problems. This was at a colossal loss to the government because his predecessor had signed the contract for the metro-line's construction. In addition he lost a great opportunity to solve the intractable problem of traffic congestion.

One of the governmental institutions GVM6 established to help assess plans and programmes was the Plans, Programmes and Budget Bureau (PPBB). Responsibilities of this Department included the monitor and control of economic planning matters. It also carried out analysis and evaluation of government projects. Project quality improved due to the evaluation made by this Department. According to RSSG, "PPBB had circular for awards of contracts stipulating the conditions. It was a very good process. The staff were very hardworking and competent. This helped to give credence to the work of the Department. Staff and contractors had respect for and confidence in the Department."

Looking back RPSIII said, "GVC5 and GVM6 contributed to the quality of the Civil Service Monthly meetings. Issues were discussed and solutions suggested. The Governors were educated on the workings of the various ministries. They knew what was happening, and officers from middle-level management GL13 to the Directors and the Permanent Secretaries were involved at these briefings." The leadership traits of these Governors were participatory, although both had civilian and military backgrounds.

\section{Summing Up on GVM6: Factors Influencing Governance and Leadership}

Like his immediate civilian predecessor, he had focused policies. His policy emphasized quality in all areas of governance and social delivery. Although from a military background, his leadership style was participatory and he was thus able to make effective use of the civil servants. The following is a summary assessment of the Governor: 
- Personal qualities: He exhibited good self-discipline and moral rectitude. He also enforced discipline, rules and regulation. He showed high sense of transparency and integrity.

- Institutional Capacity: He had a realistic assessment of the institutional capacity of the civil service and he used it very effectively.

- Policy thrust: He had a strong vision and mission for the improvement of the civil service and the society. He instituted policies that positively affected the welfare of the people.

- Participation of the Bureaucracy: He had the ability to lead and inspire staff through hard work, brilliance and uprightness.

- Perception of the Bureaucracy: He regarded the bureaucracy highly.

- Perception of the Governor by the bureaucracy: He was participatory. He had a good moral character that the people wanted to emulate.

\section{GOVERNOR GVM7 1986-1988}

One of the initial tasks of GVM7 was to do the state tour in order to acquaint himself with the state's problems. In our interview he said

"I did not make my maiden speech until I toured all the local governments. I discovered that the problems of Lagos State were administrative, economic, environmental, housing, education and health."

He continued his predecessors' concerted efforts in education. According to him,

"GVC5 met the horrible three shifts system when he took over office. With this and his own educational policy of free education at all levels, he needed classrooms to house the students. Classrooms were built on any available grounds. Infrastructural facilities like play grounds were destroyed to make space for the classrooms. We believe in qualitative education. GVM6 tried to review some of the policies of GVC5 and bring in some quality. We also tried to make the classrooms to be appealing to the students. We wanted to provide a good environment for the students to learn. We decided to go to the rural areas and build boarding schools there. This also provided a socio-economic development to the rural areas."

According to PRSIV "GVM7 established the Model Colleges in order to satisfy the yearnings of the people who wanted good schools with high standards which can be compared to the standards of the Federal Government unity schools." GVM7 made his legacy in education by continuing the classrooms replacement programme, the provision of science equipment for 111 schools at the cost of 37.4 million in 1987, and the establishment of the Lagos State Public Service Staff Development Center at Magodo. He also established the five fee-paying model colleges at the rural parts of the five administrative divisions of Lagos State. The establishment of these schools now caused the government to open these communities and provide them with roads, water, and electricity. These helped in the enhancement of his Integrated Rural Development Programme.

During his tenure, he embarked on massive electrification projects, completing and commissioning twenty rural electrification projects. By January 1988, he had committed 41,657,067 Naira for 46 additional projects; and 1,936,375.6 Naira in April of the same year for another five rural electrification projects. Between January 1986 and June 1988, he had embarked on the construction of $1,216 \mathrm{Km}$ of roads into the rural areas. In the area of rural water supply projects, in 1987, the Ogun-Oshun River Basin Authority completed five of the forty-five boreholes earmarked by the Federal Government, under GVM7's administration. Afterwards, the state government now constructed another seven, at the total cost of $647,895.13$ Naira. Another major thing he did in this area was the award of twelve microwater schemes in the rural areas. 
Commenting on the regime of GVM7 Shodipe, (1997:121) said, "He unloosed a comprehensive rural development focus with the inherent predication of improving the standard of living of rural dwellers. In a programmatic orchestration of his ultimate agenda, (GVM7) first began with the incremental measures, sensitising the rural targets with pilot schemes, which ranged from the Homestead Fish Pond to the reactivation of Community Development Associations, the inauguration of Agricultural Land Holding authority and the establishment of a tourism committee. The basic aim here was to strip the rural areas of their vitiating stigma of abandonment by bringing the government closer to them. This way, the needs of the rural dwellers are better understood and effectively managed."

When analyzing the policy direction of GVM7 informant RSSG said, he warmed up to the Federal Government. According to him, "GVM7 believed that Lagos State was aloof and snobbish, and in order to get anything or its normal subvention, the Lagos State needed to warm up to the Federal Government". In the interview with him, he said,

"Lagos State has the opportunity to generate renewable strong partnership with the private sector and Federal Government in the areas of common interest; there was a cold war between the Federal and Lagos. So I established the Liaison office that would monitor the activities and requests from the Federal Government".

This approach paid off because his government convinced the Federal Government on the reasonableness of completing the third mainland bridge axial road. The cost of the project was 555 million Naira, towards which the state government pledged 60 million Naira. Some federal roads were also completed and his regime also saw the construction of the Ikeja flyovers and the commissioning of the Opebi ${ }^{44}$ link road to minimise traffic congestion and improve vehicular movement.

In housing, he intensified the inherited programme by improving on the quality of houses built under GVC5. He awarded a contract of 131.8 million Naira for the construction of 412 Duplexes, 504 medium cost flats and 2,000 low cost housing estates. The programme's intentions were good but the implementation and award of the houses to the populace went poorly. The government got a lot of criticism from the press. Commenting GVM7 said,

"The populace misconstrued the intention of government when they were requested to pay deposit for the allocation of the house they wanted to purchase in Dolphin Estate. They said I wanted to pay the contractors for the work they have not finished. But I wanted to pay the contractors their money in order to avoid variation. Anyway when I left, the cost of the houses jumped up as the contractors requested for variation due to inflation"

However, the tenacity by which the Governor tried to develop rural areas was not fully appreciated because the elite and the majority of the populace live in urban areas. Although at his inaugural speech he promised to raise the standard of living for citizens of Lagos State, he was not responsive to the socio-economic needs of the metropolis. He also did not continue with the metro-line project cancelled by his immediate predecessor, and his provision for an alternative transportation by the purchase of some jetties and buses remained inadequate for the teeming urban populace. The urban roads started to deteriorate again, and with this come the attendant traffic problems. Although, he increased the health sector's appropriation from 10million Naira in 1987 to 22.2 million Naira in 1988 to upgrade and rehabilitate the health facilities; at the same time he abrogated the free health policy of his predecessors. Coupled with this, his regime was plagued with incessant drug shortages.

Some of the informants felt that GVM7 could have done more for the metropolis, instead of embarking on some wasteful projects like the building of the "Lagos house" when the state government already had three other official residents for the Governors. Most people

\footnotetext{
${ }^{44}$ Ikeja and Opebi are major areas in the Ikeja Local Government that housed the Lagos State Secretariat, industries and commercial centers and therefore a very busy area of Lagos State.
} 
regarded the building of the Teslim Balogun stadium just in front of the National stadium as misguided and wasteful. According to DSII, "GVM7 was not particularly environmentally cautious in building the stadium in front of another stadium. Subsequent governments stopped the construction because if the stadium should become operational it will lead to unprecedented traffic congestion in that area. Right now when there is an activity at the National stadium there are usually traffic clusters that take many hours to decongest". In his defense however, PSSIV said, "GVM7 really tried for Lagos State, but the issues of the state house and the stadium gave him a bad publicity. GVM7 embarked on the government house because according to him, the government houses in Isaac John and Marina are not ideal for business transactions. On the issue of the stadium, there are many secondary schools with no sporting facilities". Commenting on this, GVM7 himself said,

"I embarked on the government house because the money spent on protocol was enormous. Most of the time we have to host people at the hotel, and I felt that we must build the government house near the office. On the issue of the stadium in Surulere, most of the playgrounds have been converted to classrooms, and I believe that students must have sporting facilities. I did not get the opportunity to finish it and my predecessors also abandoned it"

Commenting on his tenure, RPSIII believed that "GVM7 was not as focused on the provision of public service delivery in the urban areas as he was with the rural. He did not follow any particular programme." In a brazen act of insensitivity, the Governor erected a bronze statue of a soldier in full regalia pointing a machine gun at the House of Assembly. Heated criticism of the statue finally led the Governor to dismantle it. Summarizing, Shodipe, (1997:130) records, "Whereas GVM7's legacy was without significant concreteness in the metropolis, the regime endears in intangible gestures". This was at a time when inflation had started biting hard on the economy and the citizen believed that every Naira should be well spent on tangible benefits to the whole state.

\section{Summing Up on GVM7: Factors Influencing Governance and Leadership}

GVM7 concentrated on integrated rural development to the detriment of the metropolis. Many of the projects planned for the metropolis were seen as lavish and wasteful spending of government funds. He was seen as distant and detached by the bureaucracy, and not sensitive to the populace's needs as the infrastructure like roads in the metropolis have started to deteriorate again. The implementation of some of his programmes lacked transparency. He had a strained relationship with the higher civil servants because of his habit to advance some staff to the detriment of their superiors. The following is a summary assessment of the Governor:

- Personal qualities: He appeared distant and aloof; this exposed him to charges of lack of transparency.

- Institutional Capacity: He did not make use of the institutional capacity effectively. He was selective in his use of the bureaucracy.

- Policy thrust: He did not implement policies that would benefit the majority of the people. While many of the rural programmes were commendable, some metropolis polices lacked proper judgment and caution.

- Participation of the Bureaucracy: He was not participatory like his immediate two predecessors. He was not able to get the best out of the bureaucracy ${ }^{45}$.

- Perception of the Bureaucracy: He believed that the bureaucracy is effective. GVM7 said that "In terms of quality, I believe the civil service has quality"

\footnotetext{
${ }^{45}$ This is further discussed in Chapter 5 under "Relationship between military and administrative leadership".
} 
- Perception of the Governor by the bureaucracy: He was seen as being distant and detached.

\section{GOVERNOR GVM8 1988-1991}

The emphasis on social delivery responsibilities over the development of viable economic projects had started taking its toll on government's treasury. This was further compounded by the severe economic reversals in the mid-1980s that led Nigeria to adopt the Structural Adjustment Programme (SAP) with attendant currency devaluation. In order to succeed at this period in the governance of Lagos State, GVM8 needed to enhance the human and material resources available to him. In the interview with GVM8, he said,

"The task of governing Lagos State was enormous. It is a small state in terms of landmass, but huge in population, with people from all over the country, it is a mini-Nigeria. The culture of the people had to be studied, that is the Hausas, Igbos, Yorubas, Ibibibios etc and also the diplomats who came from all over the world. The tasks were colossal. The focus of my administration was continuity in government and improvement of what we met."

The major policy thrust of this government was "efficient financial administration based on forward-looking planning, determined revenue-collection strategy and sound accounting system" (Lagos State Ministry of Information). In view of the dwindling revenue of the state, currency devaluation and galloping inflation, liabilities of the state rose and a once buoyant state started to have financial strains. The government needed more avenues to generate funds for the execution of its programmes and public service deliveries to its people. The government embarked on the opening of more tax offices to augment the efforts of the existing tax stations. To better administer the road taxes, the Central Licensing Office was transferred to the Ministry of Finance and Economic Planning. There were renewed efforts to get the Federal Government to release the State capital-grants on time. The Revenue Advisory Committee was reconstituted in order to improve its operations. The Funds Allocation Committees were subsequently set up to ensure the state government had realistic control of its public expenditure budget. This regime was noted for its prudent financial management.

This administration was able to generate money through its incentive policy and the commercialization of some of the agencies. Commenting on the revenue drive GVM8 said,

"The recurrent expenditure was becoming too heavy to pay. I did not believe in sacking or throwing people into the unemployment market. We therefore decided to commercialise water, transport and public works. The State was able to make some savings through this. Also some parastatals that were self-sufficient were made to start paying the salaries of their staff. Further, the government started giving incentives to the money generating Ministries. We gave targets to the revenue generating areas. If you meet the target, whatever is the excess made, 10\% went back to the Ministry as part of bonus. We needed to give them incentives. The targets were met and most of the time surpassed".

This was a significant achievement during an especially difficult economic period in Nigeria.

Further proof of this is recorded in Chapter three - Political Leadership and its Influence in Public Policy in Table 3.2: Lagos State Government: Recurrent and Capital Expenditures, 1968, 1978, 1988-2001 (in Million and Percentages). The table shows that he was one of the Governors that was able to maintain a relatively low percentage of recurrent to capital expenditure, meaning that the regime maintained a fairly decent fiscal stance and spent more on development related projects. It was not just one policy instrument but rather it was the dynamics of the regime's overall policy and the set of institutions such as a reinvigorated tax and the incentive system that worked together. 
GVM8's administration was therefore associated with improvement in the state's educational system. The following State institutions were established to manage and administer the different education tiers in terms of appointments, promotions, transfers and discipline Primary Schools Management Board, Post Primary Teaching Service Commission, Local Administrators of Education, re-introduction of Board of Governors to Public Secondary Schools and the Inauguration of Board of Trustees for the Management of the Educational Endowment Fund. To encourage uniformity in the standard of education, the state introduced the state-wide common entrance examination into public secondary schools, teachers training and technical colleges. There was resuscitation of boarding facilities, reintroduced to some public secondary schools. More staff were employed for both primary and secondary schools. Over 6,000 classrooms were built and 2,500 school laboratories were provided.

In the health sector, new institutional forms emerged such as the inauguration of Drug and Medical Consumable Revolving Funds Committee. The committee had the responsibility of ensuring speedier procurement and distribution of drugs. The government heavily subsidized drugs and medical consumables and sold to the patients at minimal rates. The administration tried to promote trust and unity amongst the traditional health practitioners. Model clinics were established, and aspects of traditional medicine, namely obstetric and gynaecology, psychiatry, bone setting, were performed at the herbarium at Epe ${ }^{46}$. In the area of agriculture, the government encouraged farm mechanization in order to boost food production. Over 1,500 schools were exposed to agricultural programmes in order to create an awareness of the importance of agriculture. The Agricultural Training School Araga, a semi-autonomous practically oriented, vocational institute, was established (Lagos State Ministry of Information).

The administration continued the rural development efforts of his predecessor. He completed and commissioned the Agura-Igbokuta-Imota road, Igbogbo Offin-Oreta road, IlaraIgbonla road and road development for about 127 rural border communities in Badagry with over 30 million Naira. He also provided over 35 water projects in various rural communities. He built several rural housing units and trained some communities in the skills of cheap building. In order to ensure continuity of his rural community development programme of social mobilization, rural industrialization and technology, he established the Center for Rural Development at the Lagos State University.

Noting Lagos's importance as a commuter state, he was unrelenting in the repair of drainages, roads and mass transportation. The third axial Bridge was commissioned during this regime, and this greatly helped the state's socio-economic life. He tried to improve traffic management in the metropolis by buying four more ferries in addition to the existing two. $\mathrm{He}$ dredged and constructed new terminals and small terminals for the ferries in different parts of the city and increased the State Transportation Corporation bus fleet. In collaboration with the Nigerian Railway Corporation, the government tried to increase the activities of the rail system by how on time they ran.

GVM8 believed the cheapest and most effective way to health care delivery system was through a clean environment. He created the Ministry of Environment and Physical Planning and established the Pollution Control Laboratory. He re-enacted the edicts on environmental sanitation, street trading, and pollution control. He introduced the Industrial Premises and Local Government Environmental Sanitation Competition to stimulate the development of clean and healthy environments. This government continued to observe environmental sanitation day, and retained the Task Force on Environmental Sanitation. Commenting on GVM8, informant RPSIV said, "He was very hardworking and fair-minded. He would insist that every contractor should be paid. He completed most of his projects." Concurring, DSII said,

\footnotetext{
${ }^{46}$ This was an innovative and commendable institutional innovation in health care delivery. Majority of the poor rely on unorthodox medicine, although the success of the initiative is debatable.
} 
"GVM8 worked tirelessly and he did a lot on roads and drainages. He understood the peculiar terrain of the state".

\section{Summing Up on GVM8: Factors Influencing Governance and Leadership}

GVM8 came into governance during a period when the country as a whole had started experiencing severe economic hardship and Lagos State was no exception. However, he tried to enforce transparency and accountability. He commissioned the Lagos State Broadcasting Corporation and started a phone-in programme where state functionaries, often Commissioners, gave a quarterly account of their stewardship to the press and populace. The following is a summary assessment of the Governor:

- Personal qualities: He exhibited good self- discipline and moral rectitude. He also enforced discipline, rules and regulation. He showed high sense of transparency and integrity.

- Institutional Capacity: He had a realistic assessment of the institutional capacity of the civil service and he used it very effectively

- Policy thrust: He had a strong vision and mission for the improvement of the civil service and the society. He instituted policies that positively affected the welfare of the people.

- Participation of the Bureaucracy: He had the ability to lead and inspire the staff through hard work.

- Perception of the Bureaucracy: He regarded the bureaucracy highly.

- Perception of the Governor by the bureaucracy: He was participatory.

\section{GOVERNOR GVC9 1992-1993}

The agitation of the Nigerian populace led to the military's promise to return Nigeria to civilian government. After nine years of military rule, state governance became democratic, although a Military Head of State still ruled the country. GVM8 therefore handed over to a democratically elected Governor. GVC9 became the second civilian Governor of Lagos State. Economic and political issues dominated his tenure. The economic issue was the continuation of the economic structural adjustment programme (SAP), while the political dimension concerned adjustment to the new political dispensation after prolonged military rule.

As the dismal economic performance of Nigeria persisted, salaries were insufficient to support workers and their families. Absenteeism and lateness started to increase. Both junior and senior staff engaged in moonlighting in order to cope with the economic situation. Many civil servants borrowed to make ends meet, while senior civil servants survived by awarding government contracts to themselves and their followers. Consultants engaged in bribery that subsequently affected the quality of their work. This was the economic situation facing GVC9. However, unlike his predecessor who met a similar situation and faced the challenge through human and financial mobilization, he was unsuccessful.

On his views about the problems of governance in Lagos State, GVC9 said,

"I did not anticipate that the problem would be so great. I did not. I knew that corruption had become endemic in Nigeria and I wanted to fight it my own way without revealing my strategy to the people. The civil servants are not adequately remunerated and that breeds corruption. A hungry man will go to any length to make extra money. One needs to get to the root of corruption and cut it at the bud. If corruption is reduced the civil servants will not have an umbrella to hide under".

Although, he aptly summarized the economic dilemma the workers faced, he did not do anything to contain it. He did not trust the bureaucracy. He was very aloof with the civil servants and he tried not to interfere with them. According to him, 
"I did not get to restructure the civil service; I left it for the Civil Service Commission. I tried not to interfere with what were not my duties. I was careful not to dabble into areas that were exclusive jurisdiction of the Commission."

According to PSS III, "GVC9 was not in charge. It (became) a civil service (where) anything goes."

The Governor's remarkable "strategy" of staying away from the bureaucracy hampered the effective execution of most of his programmes. In his maiden speech, he promised the emancipation of the common person through the provision of adequate housing, transportation, pipe-born water, free and qualitative education, and health services. He even tagged his budget the "Budget of Reality and New Direction". According to RSSG "GVC9 had a vision of making Lagos a State of Excellence, but he did not have the political legitimacy or the strategy to implement his programmes.

He introduced the "Jubilee Housing Scheme" and the "Jubilee Transportation". The administration planned to build 100,000 Jubilee Housing Scheme for low-income earners. Two-bedroom bungalows were supposed to be handed to their owners within few months after the initial payment of 100,000 Naira. Many people paid. In his comments on the execution of the project, Shodipe (1997:161) said "an exuberant GVC9 quickly released the funds to various contractors, some of whom were paid as much as $70 \%$ of the total cost of the project in advance. The decision soon proved unwise; contractors were not properly monitored, funds were lavishly disbursed without supervisory guidance. Months graduated into a year and yet the sites remained desolate. Most of the contractors have deserted the project after putting up some few skeletal units. The one located at Omole, in Ikeja Local Government was just completed in 1997 by GVM11".

In the area of mass transportation, the Governor had promised to resuscitate the Metroline and had asked the opposition party for their support, but this did not materialize. Although an initial sum of five million Naira was earmarked to resuscitate the project, the Metro-line never became a reality. In the Jubilee Transportation scheme, the government purchased and distributed 90 buses to private transporters on wet-lease agreements to manage on behalf of the government. The goal was to alleviate the populace's transportation problems, but implementation was faulty. "Without firm contractual obligations, the private transporters were quite reckless. They defaulted in their payments to the state. The vehicles were not properly maintained and many were soon grounded. The ferry scheme and the rail line were also vitiated by managerial fraud and incompetence" (Shodipe, 1997:162). In other words, the legal or institutional basis of the programme was faulty. In the areas of other social deliveries, this administration did not make any notable impact. He left office before most of the proposed programmes in the areas of rural development, health, education, and the construction of new roads happened ${ }^{47}$.

One legacy GVC9 left was the payment of bad debts left by some of his predecessors. In the past during the time of GVC5, Lagos State had loaned money to some of the country's impoverished states but by the time GVC9 assumed office, the Lagos State had become a pauper state with empty coffers. He laboriously went through claims of the debts owned by the government and made sure genuine claims were paid to both the financial institutions and the contractors. Talking on this issue, GVC9 said,

"I paid many debts that were ignored for years. Lagos State Government borrowed 40 million Naira to buy some buses, and there was another loan to build the Lagos State Brewery. We paid the principal and negotiated over the interest, and we paid the agreed amount".

The Governor recounted his experience with a contractor as follows:

\footnotetext{
${ }^{47}$ The only exception was the dual carriage road constructed to link Ikeja to Ikorodu, which used to be a traffic nightmare for motorists when it was a single lane road.
} 


\begin{abstract}
"A Commissioner brought the sum of 1 million Naira to me in a parcel and said that it was a gift from one of the contractors who had just been paid his money. The contractor was surprised and wanted to thank the Governor. I told the Commissioner that I did not labour with the contractor when he was doing the job. I therefore told the Commissioner to return the money, and he broke down crying. The contractor came to thank me and said that my type of Governor is different (Iru Governor yin mayato ${ }^{48}$ ). The Commissioner was sacked but I credited him for telling me the truth".
\end{abstract}

Politically, he came to power amid political hostility from an opposition party that lost the election through internal bickering. With his party having only four members out of thirty in the Legislature, his regime could not lay claim to any piece of legislation except the abolition of the moribund Lagos Motor Traffic Edict" ${ }^{49}$. According to PSS III, "GVC9 tenure was insignificant in the Legislature. Members of the House were able to get whatever they wanted from the Executive, because the relationship between the Governor and the Legislature was that of subtle hostility." This was unlike the tenure of GVC5 whose party had the majority in the legislative. Within the span of two years (1979-81) he had passed 37 bills into law.

On his view on the Judiciary he opined,

"Yes, one gets wiser every time. I told Governor GVC12 that he did something I liked very much, although I did the opposite in the appointment of judges. He appointed young lawyers who will grow on the job. They will be able to grow and get to the Supreme Court before retirement".

From the Legislature, Executive and the Judiciary perspective his tenure was very uneventful.

On the larger political scene, a series of riots dogged the latter part of his administration after the annulment of June 12 presidential election, won by Bashorun M.K.O. Abiola ${ }^{50}$. The Military Head of State at the center did not want to relinquish power. Lagos State, being a politically volatile State, was engulfed in serious riots when the citizens went on such a rampage that even the police could not contain them. The Chief of Defense Staff, General Sanni Abacha summoned GVC9 and the Speaker of the House to a meeting at the Defense Headquarters and gave them an ultimatum that the riots be quenched within 24 hours.

The army knew that this pronouncement was not only impossible but also unjust as the demonstrations were not against the Governor personally. They were against an army that did not want to hand over the Federal Government to a democratically elected president in an election internationally regarded as fair. However, GVC9 demonstrated his stance for democracy when he told the researcher,

"The meeting consisted all the heads of military and police personnel. Abacha said that the situation in Lagos had deteriorated and that the government should do something immediately. I said there was no need to wait for 24 hours because everybody and everything humanly possible we have done. The statement disarmed the army, because I have heard earlier that the military planned to take over Lagos State under the pretext of maintaining law and order".

This statement showed a resolve that he could not be intimidated by the military. However, his administration ended in November 1993 when another military coup was staged.

\footnotetext{
${ }^{48}$ He emphasized in Yoruba language: "Your type of Governor is different"

${ }^{49}$ It was initially enacted to help to decongest vehicular traffic on Lagos roads, by allowing Odd and Even number plates to ply the roads on alternative days.

${ }^{50}$ Bashorun M.K.O. Abiola was a popularly elected presidential candidate whose mandate was denied, inspite of the fact that the election was acclaimed to be one of the fairest and freest in the history of Nigeria, even by the international community.
} 


\section{Summing Up on GVC9: Factors Influencing Governance and Leadership}

His vision for the liberation of the common person was still a dream by the time he left office, because his programmes were ill conceived, poorly introduced and badly executed. His housing projects and mass transit schemes lacked tactical implementation and adequate supervision. In his relationship with the bureaucracy, he did not utilize the institutional capacity at his disposal; he completely ignored an essential institution that was pivotal to governance.

His dignified but unhurried nature earned him the nickname of "Governor go-slow", although he was very scrupulous and meticulous in financial management and paid all the debts owed by Lagos State Government. Nobody was able to accuse him of financial misappropriation, which was one of the things he stood against. He laboriously went through claims of the debts owned by the government and made sure genuine claims were paid to both the financial institutions and the contractors. The following is a summary assessment of the Governor:

- Personal qualities: He showed high sense of transparency and integrity.

- Institutional Capacity: He did not understand the institutional capacity of the bureaucracy and therefore did not make effective use of it.

- Policy thrust: He had a vision and mission to make Lagos a State of excellence, but did not have the managerial capability to make it so.

- Participation of the Bureaucracy: He did not trust the bureaucracy, neither did he have the ability to lead and inspire the staff through hard work.

- Perception of the Bureaucracy: He had little regard for the bureaucracy.

- Perception of the Governor by the bureaucracy: He was not participatory. He was very distant and detached.

\section{GOVERNOR GVM10 1993-1996}

GVM10 ${ }^{51}$, a military Governor came into governance of Lagos State in a very turbulent time of Nigeria's political history. Nigerians at this period were tired of the military and wanted them to return to the barracks. There was a growing lack of trust between the President, General Ibrahim Babaginda and the populace. The President had made many promises to the citizenry, on which he constantly rescinded. He told the populace that he wanted his government to be participatory, and requested the people to debate on whether Nigeria should take the IMF loan with its conditions. Despite strong opposition to the acceptance of the loan, his government accepted the loan and its conditions. For many years, he gave Nigerians and the international community the impression that he would hand over power to a civilian government. Nigeria conducted one of the freest and fairest elections in its history in 1993, state and local government officials resumed office, but the presidential election won by Chief M.K.O. Abiola was ignored. Chief Abiola subsequently was imprisoned and died in detention in July 1998.

In view of the political uproar and the widespread condemnation from the international community, General Babangida "stepped aside" in August 1993, and an interim government headed by Chief Ernest Shonekan was formed between August and November 1993. This government lacked legitimacy and the populace made his regime ungovernable. There was continual uproar because although Shonekan was a civilian he was not elected, but rather appointed by the military. With time, political instability in the country gave the military another opportunity to return to power. General Sanni Abacha became the Head of State (19931998), and Nigeria experienced the worst period in its existence as a State.

\footnotetext{
${ }^{51}$ All the attempts by this researcher to interview GVM10 proved abortive. He was the only one out of the living ten Governors that the researcher did not get access to, after several attempts.
} 
This period was noted for human rights violations, opposition activists were arrested and sometimes killed and journalists were imprisoned or simply disappeared. Abacha administration enacted many punitive laws, mostly against the press. The quality of governance deteriorated, patrimony became entrenched, as the military Governors became laws unto themselves. Internationally, Nigeria became a pariah state; donors left, and multi-nationals corporations (MNCs) were afraid to invest in the country. When he died in June 1998, he was succeeded by General Abdulsalami Abubakar, who, in June 1999, handed the governance of the country to a democratically elected government, in the person of General Olusegun Obasanjo.

According to RSSG "GVM10 came into governance at a very precarious time in Nigeria. Majority of his time he spent in the pacification of the Lagosians following the annulment of the June 12, Presidential election. He did not introduce any new projects, except the commissioning of the Opebi-Oregun Bridge." GVM10's tenure witnessed a series of strikes supported by diverse organizations like the Manufacturing Association of Nigeria (MAN), Nigerian Labour Union (NLC), Academic Staff Union of Nigerian Universities (ASUU), National Association of Nigerian Students (NANS), Nigerian Bar Association (NBA) and many prodemocracy groups. Lagos State workers also participated in the strikes. They demanded for increased salaries to combat inflation. The gradual removal of subsidies from petroleum products had led to the significant transportation cost increases especially in urban areas. The continual devaluation of the Naira also increased the level of hardship faced by government workers in Lagos State.

The first assignment performed by GVM10 was to abort proposed strike by the Lagos State branch of the Nigerian Union of Teachers. The primary school teachers gave the government a one-week ultimatum to settle several months of unpaid salaries. This situation occurred because the Federal Government's contribution to salaries under the Universal Primary Education scheme had not been regularly paid to the state governments. In sympathy with their colleagues, secondary school teachers vowed to join the strike. GVM10 was able to avert this crisis by paying the teachers their arrears after negotiating millions of Naira in loans from financial institutions. Thereafter, the administration introduced the Lagos State Educational Development Levy of 20 Naira per adult. The schools' administration and the Parent/Teacher Associations had discretion over use of the money.

Another area of success for GVM10 was the administrative staff audit. By 1996 total actual recurrent expenditure had risen to 5,322,000,000 Naira, of which 1,756,000,000 Naira was for personnel cost. This was astronomical when compared to a decade earlier in 1986 when the total appropriation for General Administration was only 20,500,000 Naira. The exercise, termed "Pay at Sight", ensured the payment of the workers salaries only after a committee had seen them. This helped to minimize the incidence of "ghost" workers ${ }^{52}$. Many top management staff, especially in the Teaching Service Commission, inflated the employee payroll with records of phantom employees, and retained employees who were dead, retired or had been sacked earlier by the government on the payroll. Aside from this relative achievement in the civil service administration, GVM10's tenure did not achieve much in the area of public services.

Like his predecessor, there was continued neglect of infrastructure. The roads had increasingly deteriorated and many were becoming impassable. In his summary of this period, (Shodipe, 1997:173-174) says, "the once well-tarred roads were quickly being obliterated, ridden with pot-holes, then stricken by widening craters which soon transformed into frightening gorges that appeared to swallow the daring motorists. At various sites in Lagos, motorists had to improvise their own by-pass and the outlets, which invariably worsened traffic

\footnotetext{
${ }^{52}$ The researcher was not able to get the report of this particular exercise, so the number of ghost workers could not be ascertained. However, staff auditing has become a regular feature in the public administration of Lagos State. This has helped the Government to have a near accurate number of its staff.
} 
congestion. For instance the Lagos-Badagry Expressway was severed at a point called IleEpo, thus forcing motorists to use a nearby petrol station as a temporary thoroughfare. Commercial drivers often withdrew their vehicles from the roads or increased their fares, thereby contributing to the suffering of the masses. Many commuters had to trek long distances to work because of unavailability of vehicles or the prohibitive fares. (GVM10)'s response to all this was that he could not get bitumen to tar the roads."

As the economic situation in Nigeria deteriorated, more people migrated to Lagos State seeking the proverbial golden fleece. However, Lagos State was also going through its own economic strains, with many factories laying off staff or closing down. Businesses were not doing well. The government was at a loss on how to manage the urban immigration. The rate of crime increased. This put the administration under pressure due to security inadequacies and absences that affected both lives and properties. The special anti-crime security apparatus established by the government to assist the police, "Operation Sweep", was largely ineffective. "Neighbourhoods were raided with tipper loads of robbers who went from house to house with formidable brandish of terror, cudgelling every resistance to submission, carting away everything from cash, electrical appliances and jewellery to the minutest memento in the household. They were usually unhurried, bristling with bravado and murderous assurance. Often they stayed for hours, savaging their helpless victims without fear of police intervention. Everywhere there was a general lawlessness: the abandonment of harmless citizens to the virulence of bandits, the splendid ineptitude of power, which emboldened the venom of the wicked" (Shodipe, 1997:180).

Increased migration into the state overstretched the existing infrastructures. Garbage started piling up in the streets; people dumped refuse indiscriminately. The drainages became blocked and contributing to flooding. Hawkers contributed to traffic congestion and discarded packaging was everywhere. In order to get rid of these "nuisances", the Task Force on Environmental Sanitation and Special Offences went into action with the mission to make Lagos clean. The citizen protested the daily harassment of the reckless and out-of-control task force, who were mostly military personnel that treated the populace with lack of respect and dignity. According to (Shodipe, 1997), 300 shops constructed by the local government at the cost of about five million Naira and paid for by the marketers at Ladipo Main Market were demolished on January 4, 1994 without any compensation from the state government. Perishable merchandise of petty traders was constantly destroyed. Pedestrians were forced to pick rubbish from the streets and some were given brooms to sweep the roads. There was horrendous show of power by the military to rid the state of illegal structures and street trading. The traders lost millions of Naira at a period of terrible economic hardship.

\section{Summing Up on GVM10: Factors Influencing Governance and Leadership}

The insensitivity of this regime epitomized what was happening at the federal level; the people were alienated from the government. The military government at this time did not show any accountability to the governed; the citizens neither trusted nor expected government to provide them with public service deliveries. Neighbourhoods set up their own vigilante groups because the security situation had deteriorated very badly. The political situation in Nigeria was so volatile, especially in Lagos State, that the administration did not pursue any particular public policy. Lagos State, like the rest of the country, was in a state of uncertainty. The following is a summary assessment of the Governor:

- Personal qualities: He was not able to translate his vision into reality due to the incessant political unrest.

- Institutional Capacity: He did not have a realistic assessment of the institutional capacity of the civil service and he did not use the bureaucracy effectively. 
- Policy thrust: He understood neither the extent of the problems nor how to make policies that would improve the lives of the people positively.

- Participation of the Bureaucracy: He did not have the ability to lead and inspire the staff.

- Perception of the Bureaucracy: He did not regard the bureaucracy highly.

- Perception of the Governor by the bureaucracy: He did not inspire the staff through hard work and brilliance.

\section{GOVERNOR GVM11 1996-1999}

According to a 1996 World Bank report, ${ }^{53}$ "Nigeria's urban infrastructure is crumbling. Water supply, sewage, sanitation, drainage, roads, electricity, and waste disposal-all suffer from years of serious neglect. Periodic and routine maintenance, by far the most cost-effective infrastructure spending, is almost zero. It has become the norm in Nigeria to wait for a capital infusion to rehabilitate, replacing instead of maintaining the infrastructure. But declining financial resources are making this less feasible, and the deterioration is accelerating. There is a high level of abandonment of capital projects and decline in maintenance of basic infrastructure like roads, schools, housing, waste disposal, drainage, transportation. Compounding the situation is the rapid urbanization, mostly migration from the rural areas." This description aptly describes the situation that confronted GVM11 when he came into governance. Majority of the states were economically weak because of high dependence on the federal for their resources. The economy continues to be monoculture with oil as the main revenue generator.

In the interview concerning his period as Governor of Lagos State, and the plans and programmes executed by his government, he said,

"We studied the outstanding problems like roads, security, education and health. We took stock of the resources and prioritized. In my maiden broadcast, I pinned down the security of lives and properties, and roads as our priority. By 100 days we made definite impact". The immediate problem of Lagos State was the perennially bad roads that people refer to as "death-traps and gaping craters" The other major problem was the lack of security for lives and properties.

Lagos State is highly urbanized ${ }^{54}$ with a peculiar topography. The poor state of roads in Lagos State is aided by the fact that it is an island with a high water level and restricted land area. Of its land area, $17 \%$ is either water or with wet surface. In addition, most of the development has been concentrated in Lagos metropolis - around the ports, train and bus terminals. The need for land led to extensive government reclamation of lands from the swamps, lagoons and seas in the southern and western parts of the state, which constitutes the industrial and commercial hub of the state. The fragile terrain and ensuing traffic congestion subject the road surfaces to continual pressure requiring constant attention and maintenance. In addition, the lack of sustained development of rail and water transportation leads to excessive demands on these roads.

Again, due to its dual role as state and federal capital (until 1991), the human pressure on the limited space had been intense. Resources are spread thin to fulfil this dual purpose. Since the relocation of the federal capital from Lagos, the Federal Government had pointedly neglected the roads it constructed that are under its jurisdiction for maintenance purposes. There has always been a running battle between the state and the Federal Government on this issue. The Federal Government had been a major investor in Lagos State in terms of buildings

\footnotetext{
${ }^{53}$ Findings: Africa Region. Number 62.May 1996 pg.1, a periodical by the Africa Technical Department of the World Bank made the following reports on the Nigeria's economic and sectoral areas in Nigeria

${ }^{54}$ In relation to other states in the federation according to the United Nations indices for comparative development (Centra, UNRISD 197) in terms of demography, health, nutrition, housing and related activities, education, transportation and services, communications, industry, foreign trade, general economic indicators and technology.
} 
and road networks. Since the relocation of the federal capital in 1991, many roads are neglected creating major environmental problems and expensive maintenance costs for the state. Furthermore, as the citizens cannot distinguish between federal and state roads, aspersion is usually cast on the Lagos State Government for neglected road repairs. Since the Lagos metropolis is a commercial and industrial center, the ability of workers, industrialists and traders to move from one point to the other at the shortest time and convenience are of great importance to the populace. For this reason, the populace will always rate any government that has a good roads maintenance policy very highly. His campaign for road reconstruction and rehabilitation was called Operation 250, where 250 roads were selected. 202 roads were patched up within eleven months.

By the time GVM11 assumed office, many of the roads were in total disrepair, with attendant unrelenting traffic congestion that showed itself in the productivity and economy of the state. The attention this Governor gave to transportation infrastructure is evident in the financial allocation to this sector. In 1996, 12.59\% of the total capital expenditure was allotted to Transportation, behind General Administration at $14.56 \%$ and Special Expenditure at $21.92 \%$. In the subsequent year, as a further show of emphasis, this administration divided transportation into two sections: Roads and Public Transportation. Sectoral allocation for Roads was the highest compared to other sectors at $19.35 \%$. This period witnessed the most extensive reconstruction and rehabilitation of road networks in Lagos State.

According to RPSII, "GVM11 was responsive to the people's demands. He was hard working, humanitarian and wanted the citizenry to be happy. He behaved more like a politician". Commenting on whether there was any element of trust between him and the people he governed, GVM11 responded,

"People still celebrate our tenure. We did our need assessments and found out what were the problem areas that needed to be methodically addressed. They were practical things, roads and security; people slept easily and drove over smoother roads".

Nigeria at this time continued to experience socio-economic dilemmas. The adoption of the Structural Adjustment Programme (SAP) had led to the closure of industries largely because the devaluation of the Naira made imported goods cheaper than homemade. Many new graduates could not find jobs, while job seekers and people from other states continued to move into Lagos State ("the land of opportunities") in the hope of a better life. Many became disappointed, but shame of failure would not allow them to return home and shanties and slum increased in the state. Commenting on this issue, PSSI remarked, "An average of about 6,000 people enter into Lagos daily. They came because they thought that Lagos State is economically buoyant. Many came without any skill or relations. If they did not make it, they cannot go back because of shame. They end up sleeping under the bridges, churches or go into violence."

The rate of crime increased in the state and armed robbers became very daring. Shodipe, (1997:191) succinctly puts it, "robbers reigned on the streets, invaded the homes, dictated the pace of life with vindictive largeness of the jungle". At this point, citizens needed a leader that could provide security of lives and properties. This was what GVM11 did. He faced the challenge with absolute candour. His plans were focused and result-oriented. GVM11 personally took over the supervision of the anti-crime brigade, bringing its headquarter to the Lagos State Civil Service secretariat in order to have direct access to its operations. The quality of communication network was upgraded and citizens had direct access to the anti-crime unit to report crimes or hoodlums in their environments.

GVM11 also invested in the procurement of new equipment and vehicles; he increased the fleet of vehicles to 220 from just a few, ordered 4,000 bullet-proof vests, and introduced air surveillance with the use of 2 helicopters. He also raised the operational logistics of the units at the local government level. In the 1997, 1998, and 1999 actual sectoral allocations, $3.87 \%, 4.62 \%$ and $5.73 \%$ respectively were allocated to security from the total percentage of 
the capital expenditure (Lagos State Ministry of Finance). He was the only Governor that separated security from the special expenditure votes in order to emphasize the importance he attached to eradicating armed robbery in Lagos State. Although members of the "Operation Sweep" were not flawless, violent crime was reduced considerably, and the rate of armed robbery declined in Lagos State as many of the robbers moved on to neighbouring states. Commenting on this, GVM11 said, "We brought violent crime to an acceptable level".

In the area of environmental sanitation, he continued the use of the Lagos State Task Force on Environmental Sanitation and Special Offences in his programme of 'Operation Weed to Flowers'. This was a programme where he gainfully employed the local hoodlums, referred to as "Areas Boys", who were noted for their destructive proclivity and vulnerability to criminal tendencies, to beautify the metropolis by planting flowers. The Task Force that used to be notorious for its high-handedness during the regime of GVM10 was transformed and supervised this project. Lagos State however, continued to have problems with garbage collection and disposal. In the area of transportation, he introduced the tricycle and tried to improve the train shuttle services and ferry services. He was noted for his impact in the areas of Health and Education. The Lagos State University Teaching Hospital was established and the emergency unit of the Ikeja General hospital was greatly improved during his regime. His administration also removed the fee for Senior Secondary Schools examination. He completed some of the abandoned housing projects of GVC9 and completed about seven new housing estates.

Inspite of this apparent success in the execution of his programmes, there were questions on transparency in the implementation of these admittedly wide-ranging programmes. His housing programme was tarnished by claims of manipulation in the allocation process. Allegations of acquisition by GVM11 and his cronies were rampant. There was no equitable formula for the allotment of the houses. Responding to lack of transparency and accountability, GVM11 responded that,

"I simply cannot say that there were no corrupt practices. When it happened, we investigated them".

However, commenting on the leadership of GVM11, DSI believes that "he performed well but he was not participatory. He focused on few areas to the complete detriment of others."

\section{Summing Up on GVM11: Factors Influencing Governance and Leadership}

GVM11 was very focused. In view of the decline of infrastructural facilities, especially the road network, he had to take some drastic measures. He made effective use of the existing work force (engineers, town planners, topographers, etc.) in the implementation of the road projects. He established the Lagos State Direct Labour Agency (LSLDA). He did not award the rectification of the roads to contractors, and so was able to cut down on the rehabilitation costs. Commenting on the capacity of the civil service, he said,

"during my tenure the civil servants were professionals and the service was superb. That is the truth".

For those who had the opportunity to work closely with him like RPSII, she said, "GVM11 was a mixed breed; he was both a military man and a politician. He wanted the people to be happy. He was responsive and humanitarian in nature. He was also hard working and he worked late into the night. He will always appreciate the efforts made by the people. $\mathrm{He}$ was caring and he supported hard work. He was an administrator and believes in efficiency and good training. He knew administration. He ran an open office. He could change from one leadership style to the other." However, some people would not agree with this view. They believe that he was selective in the use of the bureaucracy in the sense that he made effective use of those who were directly connected with his programmes. According to RPSIII, "GVM11 did not believe in the participatory style of GVC5 and GVM6 who always had qual- 
ity meetings with the staff. He was not really interactive, and he did not make use of the civil servants effectively". The following is a summary assessment of the Governor:

- Personal qualities: He was focused, determined and hard working

- Institutional Capacity: Although he had a realistic assessment of the institutional capacity of the Civil service, he used it selectively.

- Policy thrust: He instituted policies that positively affected the welfare of the people.

- Participation of the Bureaucracy: For the section of the bureaucracy he used, he had the ability to lead and inspire the staff through hard work.

- Perception of the Bureaucracy: He regarded the bureaucracy highly.

- Perception of the Governor by the bureaucracy: He was not participatory

\section{GOVERNOR GVC12 1999 -TO DATE}

It is projected that by the year 2010 , about 100 million people $(60 \%$ of the national population), will live in the urban areas and half of Nigeria's total Gross Domestic Product will come from non-oil sectors in the urban areas ${ }^{55}$. Trying to stop migration into the state is therefore near impossible. Despite the lack of adequate socio-economic data, it is still believed that Lagos State is the fastest growing urban area in Nigeria because of the high concentration of commercial, financial and industrial concerns in the state. However, the infrastructure is over-stretched. There is environmental degradation due to poor pollution control. Pollution is pervasive; it is in the air, water, and land. Industrial wastewater disposal is poorly managed and industries discharge untreated and often toxic wastes into sewer, open drains and lagoons. There is poor management of solid waste like sewage and refuse. Air pollution comes mainly from the volume of unserviceable vehicles streaming into the Lagos Metropolis. All these affect the health of the populace causing the cost of primary healthcare to soar. Urban planning has always defied most administrations efforts, and this is giving way to development of unplanned areas with many slums and shanties emerging. Deteriorating basic public service deliveries affect the welfare and productivity of the citizenry.

During his tenure, GVM11 focused on the immediate needs of the people, which were roads and security, although he paid some disproportionate attention to other public services. However, he could not build a lasting institutional solution to the perennial problems of road congestion, environmental sanitation and urban waste disposal. In the interview with GVC12, his immediate successor, he admitted that the problems of Lagos State

"are multifaceted and we therefore categorized them into immediate, medium and long term. We inherited limited resources and therefore planning was important. We listed the problems and then used critical path analysis. We believe in the principle of reinventing governance and therefore contracted out some aspects of revenue generation to consulting firms that has the capability to handle them".

This regime adopted many New Public Management principles, especially contracting out services such as garbage collection and revenue generation to private firms. Commenting on this, PSSIV said, "In December 1996 during a bilateral discussion with the World Bank, they encouraged the use of outside bodies to help to improve the civil service and avoid decline." This pushed the government to intensify private participation in its service deliveries.

One of the notable aspects of governance in Lagos State is its lack of resolute involvement in socio-economic development, while the cost of meeting the demands for the public service deliveries escalates everyday. This puts considerable financial burden on the state. The revenue resources of the state derive from statutory and non-statutory grants from the Federal Government, taxes from salaried workers, taxes from commercial and industrial es-

\footnotetext{
${ }^{55}$ According to the projection by findings a periodical of the World Bank-Africa Region. Number 62, May 1996.
} 
tablishments, capital taxes from land, and other revenues from fines and fees. Revenues received from the federal source are epileptic and on a decline when calculated in relative terms against inflation.

The state government is continually losing revenues from taxes due to poor institutional capacity and corruption within the tax office. According to PSSI "The staff from Board of Internal Revenue negotiates tax reduction with clients and hides behind the fact that they were inadequately paid. The staff help the clients to effect reassessment of their taxes downwards. The client also justifies this action by claiming lack of adequate provision of public services by government. It now becomes a vicious circle."

Commenting on his use of consultants in revenue generation, GVC12 said,

"We needed to improve on our revenue generation. We had to employ the services of consulting firms that are experts and have the capability to help the government to collect its revenues. This has yielded a positive result. We have been able to greatly raise the revenue and this is a great achievement."

However, the use of private firms for tax and revenue collection has been severely criticized, because it has marginalized and incapacitated the Board of Internal Revenue. The institutional capacity and capability of staff in this Department is gradually being eroded. Many of the staff are underutilized and untrained.

Government revenue collectors are neither properly trained nor given the incentives to discourage fraudulent and dishonest behaviours. Acts of indiscipline and corruption have not received the sanctions and punishment stated in the laws. Governor GVC5 used the Board of Internal Revenue to collect revenue during his regime. During this period according to (Olowu, 1990:93), there was a "3,000\% or thirty-one-fold increase in revenues between 1968 and 1983, and when allowance is made for inflation this will probably come to a $2,000 \%$ increase". This Governor used the available institutional capacity to raise the level of the state's revenue generation. The out-sourcing of revenue generation to management consultants adversely affected the morale and efficiency of revenue and tax collectors of Lagos State Civil service.

Another area that seems unsolvable, despite the money spent by the various governments, is waste management. According to RPSI, "waste management is one area that seems to have defied solutions in Lagos State except during the regimes of certain Governors like GVM6. The people sometimes leave their collected refuse on the highways and streets. These are not removed regularly, and it ultimately becomes an eyesore. There is need for stringent measures to be administered. People should be made to obey the law, by not throwing refuse on the streets, not even throwing sweet wrappers. People must know that the government spends a lot of money on infrastructures." Waste management is one main area where this government uses private initiative. Many of the informants believe that the government has not developed effective institutional capacity to solve this problem. According to Governor GVM7,

"the use of contractors is usually not good for policy implementation".

Box 4.2 is what DSII thinks on the environmental sanitation policy of GVC12. 
Box 4.2: DSII thought on the environmental sanitation policy of GVC12

GVC12 really encouraged Private Sector Participation (PSP) especially in the area of waste management. The major policy thrust of this regime in refuse collection was to have the private sector initiatives whilst the Government regulates and enforces the rule of governance.

It was believed that the PSP would handle the domestic waste collection whilst the Lagos State Waste Management Authority (LAWMA) would have exclusive monopoly of industrial wastes and the maintenance of the refuse dumps. However, this arrangement is ridden with many problems and the whole system has collapsed. The PSP was politicized. Many of the operators were registered due to party affiliation or connection with those in Government. They have no equipment and manpower capability to handle waste management. It was seen as a way of making money for the boys. The number of operators increased and the market became saturated with incompetent operators and refuse collection became unprofitable. Also their operations were uncoordinated and unsupervised.

This gave room for the cart-pushers to take over. They go to the individual homes and small companies to help collect their refuse for disposal. They are becoming a major force that cannot be wished away. People have confidence in them, but they are becoming a menace. They do illegal dumping and deposit refuse anywhere. They contribute to the problem of waste disposals in Lagos.

The problem of waste disposal can also be attributed to the lack of discipline of the people. People are not cooperating with Government. They dispose their refuse anywhere. Many put them on the median in the streets knowing that the Highway managers will eventually pick then up. Most of the time these refuse over flow into the main roads and it leads to traffic jams and unsavory sights. This has led the Government to establish Kick Against Indiscipline (KAI) unit. The staff are to arrest and fine anybody they see throwing garbage into the streets or having a dirty environment.

The Government is still in charge of LAWMA, although past Governments had wanted to commercialize it but it was a total failure. With the Government still handling LAWMA it faces many challenges. The major one is that the funding is inadequate and this is making the system to pack up. Maintenance and sustainability of the equipment, vehicles and dumping sites need constant funding. The money paid by the private operators and the cart pushers to dump refuse at the legal dumps are paid to LAWMA, which put it into the Government coffers. I believe that LAWMA management should retain some percentage of this money in order to be able to sustain these dumps. If there is no proper maintenance of these dumps, the cart pushers and the operators would look elsewhere to make illegal dumping. There should be proper maintenance of machineries and accountability of the money made. If there are no approvals for the release of funds on time, or no cash backing, or the release is late then this will make maintenance and sustenance impossible. This leads to degradation of equipment. Money obtained at the right time is more effective than one released after many months.

In my own opinion, to improve the environmental sanitation of the State the Government should look at the following:

1. Give staff the opportunity to air their views at the briefing sessions. Look at the complaints and how they can be solved. The State has trained many people in this area, and many have international exposure, they should be given the opportunity to contribute. The State is not short of good staff.

2. Limit the number of Private Sector Participation (PSP). Let registration be based only on ability and capability, and disregard political affiliations.

3. There should be more dumping sites. The disposal mechanisms are few and far between. It takes a long time to get to the dumping sites. There is a need to get more land. Go into partnership with Ogun State who has more land. Go back to incinerating the wastes.

4. There is a need to inculcate cleanliness into the populace. The Government should invest into building good environments by having parks and gardens. Lagos State used to have that before.

Source: Researcher's interview of DSII in 2003.

The implementation of this policy lacks environmental regulatory standards. Even in the areas where standards existed, the government lacked the will to enforce compliance. This is because many of the operators are party faithfuls or have "connection" with the administration. This government's policy has not been successful because many of the contractors do not have the knowledge or the wherewithal to do the job ${ }^{56}$.

\footnotetext{
${ }^{56}$ In an article in The Guardian, November 17, 2003 p. 13, written by Nnamdi Inyama titled 'Lagos: still hostage to indiscipline, negligence and decay', made the following observation "the Government has not been short of the most wonderful programmes, such as would have made Lagos one of the cleanest in the country. Yet Lagosians seem incapable of refusing to dispose off their refuse properly, choosing to dump them at the most unacceptable places, such as in the medians of high ways. Their excuse: the private sector participants, encouraged by
} 
In an attempt to institutionalize good practices in traffic management, this administration established a groundbreaking organization called the Lagos State Traffic Management Authority (LASTMA). The mission of LASTMA is to enforce discipline in traffic management. At inception, the impact of this Department was felt everywhere as the staff controlled and decongested traffic. The administration installed traffic lights in troublesome areas in order to ease the flow of traffic. Motorists in Lagos are known for undisciplined driving. In order to circumvent traffic, some even drive against traffic, manifesting a general sense of indiscipline. Public transporters flaunt traffic orders and believe that they can always get away if they can bribe their ways through the law enforcement agencies. In his response to the work of LASTMA, GVC12 said,

"LASTMA is saving lives and improving the use of the roads."

Although, the Federal Government stopped the official importation of vehicles older than 10 years, people still smuggle them in through the Lagos- Benin boarders. The majority of these vehicles end up in Lagos and contribute to air pollution while the streets are littered with unserviceable broken-down vehicles that also contribute to the incessant traffic congestions. In order to ensure that the vehicles on the roads are in good conditions, the government introduced the vehicle roadworthiness (MOT), but the programme has been poorly implemented. The efforts of LASTMA continue to be ineffective because of other inadequate supporting infrastructure.

In the educational sector, this administration carried out a major reform that had defied several governments by returning schools to their original owners ${ }^{57}$. Commenting on the hand over of secondary schools by the government, Governor GVC9 said,

"One thing I regretted that I was not able to do was to hand over the secondary schools to their original owners. We have done all the groundwork. But there was a lot of religious bigotry, and it was difficult to do. The muslims believe that the christians would have greater edge over them, because they have more schools. However, if the Government is in charge of all schools the two faiths will have equal opportunity. But there is so much work for the government that it would have been better for the private sector to run schools. Also the National Union of Teachers (NUT) was self-serving and resisted this move of Government. But I believe that if you are a good teacher the newowners will employ you. Another problem is the issue of qualification. There are so many teachers but the quality is lacking. We can only improve on the quality of teaching by handing over the schools. I am happy that the present Governor GVC12 has done that and he is a Muslim."

However, by the time the Governor handed over schools, many of the voluntary organizations had lost the institutional capacities to handle their administration. GVC12 also introduced the "millennium classrooms"

the classrooms were getting overcrowded, so we decided to rehabilitate and build additional classrooms and schools. The millennium classrooms are to augment the existing ones. The rooms are bigger and they have more facilities and laboratory equipment."

He introduced the Policy Coordinating Committee (PAC) to review the status or the progress of government work and to keep those pending in focus. He also computerized pay-

\footnotetext{
the State government to handle the disposal of household refuse seem not equal to the task, leaving Lagosians with no other option than to dump refuse anywhere decently some distance away from their homes".

${ }^{57}$ This is a reversal of the take-over of private schools affected by GVM2, a policy step that had been adjudged ill advised and expensive.

${ }^{58}$ The Millennium Classrooms are meant to be qualitatively above the extant facilities- larger rooms and better facilities for laboratory wok.
} 
roll budgeting and planning system. This has practically eliminated the problem of ghost workers while making revenue and expenditure planning more realistic ${ }^{59}$.

Many of the informants were of the opinion that GVC12 has introduced many innovations into the system, often involving private participations. However, according to DSI, "The government uses consultants in virtually every aspect of government and this is subverting the system. The private and the public sector are different and they both have different modes of operation. Many of the projects in which the private initiatives have been used had failed, for example the Property Identification Enumeration (PIE) project. The capacity of the civil service should be developed because consultancy is ephemeral and will fall away. The scope of work in the public service is far more elaborate than what private sector consultancies can handle."

Aside from deliberate marginalization of the bureaucracy in his programmes, he has introduced several policies or continued with pre-existing policies. Commenting, PSSI said, "One of the good policies of the present government is the rehabilitation of the drug addicts into 'good boys and girls'. Many were taught to become bakers, gardeners and traffic wardens. They produce high quality bread. Things are improving. This type of programme requires leadership and public awareness so that their families can welcome them back into the society." In his observation of GVC12, DSII said, "He is trying to bring back quality, his standard is high. His approach to housing is different; he is poised to implement the schemes in his own way. He had the developer scheme and owner-occupier scheme for the civil servants. In the area of health, he did more than others. If the tempo and structured approach is maintained and sustained, service delivery will improve. There is need to attract other stakeholders to governance."

\section{Summing Up on GVC12: Factors Influencing Governance and Leadership}

In the interview with GVC12, he said,

"We are taking some hard decisions which are not necessarily popular, but will benefit the larger people of the state"

According to PSS III "GVC12 came with a vision, but pressures had made him to derail from this vision. I hope by this second term people will be able to see him as a visionary leader because of the programmes he is trying to execute. These programmes are hard to implement. I hope it would not affect his tenure." New Public Management (NPM) came up with the concept of reinventing government, a process that encourages the use of private initiatives in the performance of some of the public service deliveries that were previously in the government's domain. The use of NPM has been criticized both in developed and developing countries, and the consensus has been that the rate of success depends on the capacity and capability of the government to implement it.

In a situation where governmental capability is weak, the use of NPM in government operations will not be very successful. GVC12 did not engage the existing bureaucracy in the implementation of his programmes. His tenure promoted many people from the private sector to very high positions. When asked about what he thinks of the institutional capacity of the civil service, his response was that

"It has the capacity but there are bad eggs (that) are not ready to change".

This thinking influences his relationship with the bureaucracy. According to DSI "Hopefully, the present government of GVC12 will outshine in terms of performance. He is a change

\footnotetext{
${ }^{59}$ There are more coordination between the Ministry of Establishments and Training, Civil service Commission, and the Ministry of Economic Planning and Budget. The Pension Department was excised from the Ministry of Establishments to Ministry Economic Planning and Budget. So from the resumption of an officer into the Lagos State Civil service to the time of exit, these offices now have a near accurate records and this help in the coordination of payroll budgeting and planning system.
} 
agent in the area of financial management. The initial approach to funding must change. However, he needs to mobilize the civil servants who are (among) the best. There is nothing wrong with the use of consultants, but there will always be the problem of continuity and record keeping." The following is a summary assessment of the Governor:

- Personal qualities: He is an achiever and he dares to make changes.

- Institutional Capacity: He did not have a realistic assessment of the institutional capacity of the civil service and so did not use it effectively.

- Policy thrust: He had a strong vision and mission for the improvement of the society. He instituted policies that should positively affect the welfare of the people but are poorly implemented.

- Participation of the Bureaucracy: The bureaucracy is not actively engaged.

- Perception of the Bureaucracy: He does not regard the bureaucracy highly.

- Perception of the Governor by the bureaucracy: He is not participatory and did not trust the bureaucracy.

\subsection{Perceived Performance Ratings of Lagos State Governors}

In the survey, respondents were requested to assess the qualities of successful leaders, (Governors for the political leadership and Heads of Service for the administrative leadership). Some interesting observations could be made from the assessment. While the respondents believe that there are some qualities that must be exhibited by both the political and administrative leaders to be successful, more emphasis is placed on some factors. For example, in Table 4.5 the respondents believe that political leaders need to possess a daring spirit as well as being great achievers who must have the courage to make changes. This quality was rated $40 \%$ "strong" and 40\% "very strong" for political leadership. However, the Head of Service only had $49.7 \%$ "strong" and 3.3\% "very strong" rating for this quality. In other words, the respondents associate political leaders with these attributes more than administrative leaders and the former are the ones expected to be the visionary that come up with path-breaking policies for the betterment of the society. On the other hand, the two leaders have the same ratings of $37.3 \%$ "very strong" for instituting people oriented policies. In other words, while the political leaders initiate such policies, the administrative leaders must be able to implement such policies effectively.

Furthermore, the Heads of Service received "very strong" ratings for enforcement of rules and regulations $52.2 \%$, reservoir of knowledge $45.8 \%$, realistic assessment of the institutional capacity $39.7 \%$, while the Governors were rated $47.6 \%, 31 \%$ and $28.9 \%$ respectively, for these factors. This assessment brings to fore that for any regime (civilian or military) to be successful the political leader must be a great achiever who dares to make changes, and the administrative leader must be capable and knowledgeable. 
Table 4.5: Views of Political versus Administrative Leaders: Attributed Qualities of Successful Leaders

\begin{tabular}{|c|c|c|c|c|c|c|c|c|c|c|}
\hline & \multicolumn{5}{|c|}{$\begin{array}{c}\text { Political Leaders } \\
\text { (Governors) ratings in \% }\end{array}$} & \multicolumn{5}{|c|}{$\begin{array}{c}\text { Administrative Leaders } \\
\text { (Head of Service) ratings in \% }\end{array}$} \\
\hline & \multicolumn{5}{|c|}{ Qualities } & \multicolumn{5}{|c|}{ Qualities } \\
\hline & $\begin{array}{l}\text { Very } \\
\text { low }\end{array}$ & Low & $\begin{array}{l}\text { Fairly } \\
\text { Strong }\end{array}$ & Strong & $\begin{array}{l}\text { Very } \\
\text { Strong }\end{array}$ & $\begin{array}{l}\text { Very } \\
\text { low }\end{array}$ & Low & $\begin{array}{l}\text { Fairly } \\
\text { Strong }\end{array}$ & Strong & $\begin{array}{l}\text { Very } \\
\text { Strong }\end{array}$ \\
\hline $\begin{array}{l}\text { Enforce rules } \\
\& \text { regulations }\end{array}$ & 11.0 & 1.2 & 6.1 & 34.1 & 47.6 & 6.3 & 1.3 & 11.3 & 28.8 & 52.2 \\
\hline $\begin{array}{l}\text { Exhibit good } \\
\text { self discipline }\end{array}$ & 7.5 & - & 8.8 & 45.0 & 38.8 & 7.7 & - & 14.1 & 35.9 & 42.3 \\
\hline $\begin{array}{l}\text { Institute peo- } \\
\text { ple oriented } \\
\text { policies }\end{array}$ & 10.8 & 2.4 & 7.2 & 42.2 & 37.3 & 6.7 & 1.3 & 10.7 & 44.0 & 37.3 \\
\hline $\begin{array}{l}\text { Good sense of } \\
\text { judgment }\end{array}$ & 8.0 & 1.3 & 16.0 & 37.3 & 37.3 & 5.5 & 1.4 & 19.2 & 39.7 & 34.2 \\
\hline $\begin{array}{l}\text { Reservoir of } \\
\text { knowledge }\end{array}$ & 9.9 & 8.5 & 15.5 & 35.2 & 31.0 & 6.9 & 1.4 & 9.7 & 36.1 & 45.8 \\
\hline $\begin{array}{l}\text { Realistic as- } \\
\text { sessment of } \\
\text { institutional } \\
\text { capacity }\end{array}$ & 7.9 & 5.3 & 23.7 & 34.2 & 28.9 & 2.9 & 2.9 & 10.3 & 44.1 & 39.7 \\
\hline $\begin{array}{l}\text { Vision and } \\
\text { mission for } \\
\text { improvement }\end{array}$ & 4.1 & 6.8 & 22.0 & 32.9 & 34.2 & 8.1 & - & 10.8 & 37.8 & 43.2 \\
\hline $\begin{array}{l}\text { Ability to lead } \\
\text { and inspire } \\
\text { staff }\end{array}$ & 3.9 & 1.3 & 19.5 & 35.1 & 40.3 & 8.7 & - & 13.0 & 31.9 & 46.4 \\
\hline $\begin{array}{l}\text { Encourage } \\
\text { training and } \\
\text { development }\end{array}$ & 6.0 & 2.4 & 8.4 & 36.1 & 47.0 & 4.6 & - & 13.8 & 41.5 & 40.0 \\
\hline $\begin{array}{l}\text { Great achiev- } \\
\text { ers and dare to } \\
\text { make changes }\end{array}$ & 8.8 & 3.8 & 7.5 & 40.0 & 40.0 & 5.6 & 24.5 & 16.9 & 49.7 & 3.3 \\
\hline $\begin{array}{l}\text { High sense of } \\
\text { transparency } \\
\text { and integrity }\end{array}$ & 11.0 & 1.4 & 11.0 & 46.6 & 30.1 & 4.4 & - & 20.6 & 35.3 & 39.7 \\
\hline $\begin{array}{l}\text { Good moral } \\
\text { character }\end{array}$ & 5.5 & 4.1 & 15.1 & 41.1 & 34.2 & 4.4 & - & 20.6 & 35.3 & 39.7 \\
\hline
\end{tabular}

Source: From the research survey in 2003

Based on historical records, military Governors like GVM1, GVM6, and GVM8 that had good policies and who made effective use of the bureaucracy ${ }^{60}$ performed relatively well, while a democratic government of GVC9 that completely ignored the bureaucracy got the lowest rating as being an unsuccessful Governor. Table 4.6 is the perceived performance ratings of the Governors. Table 4.6 has in addition been used to further articulate Graph 4.1 by a partial plot of the responses. I have taken the most prominent answers namely "successful" and "very successful" responses and plotted them in the graph to bring out a graphic illustration of the rating.

\footnotetext{
${ }^{60}$ The quality of bureaucracy has been cited as being a key resource in the success of the East Asian countries, (World Bank, 1996) The East Asian Miracle.
} 
Table 4.6: Perceived Performance Rating of Lagos State Governors

\begin{tabular}{|l|c|c|c|c|c|c|}
\hline Governors & $\begin{array}{c}\text { Very } \\
\text { Successful }\end{array}$ & Successful & $\begin{array}{c}\text { Not } \\
\text { Successful }\end{array}$ & $\begin{array}{c}\text { Insignificant } \\
\text { Don't } \\
\text { Know }\end{array}$ & $\begin{array}{c}\text { Total (Percent/ } \\
\text { Number) }\end{array}$ \\
\hline GVM1 & 34.0 & 37.6 & - & - & 28.4 & $100(\mathrm{n}=141)$ \\
\hline GVM2 & 6.7 & 38.1 & 3.7 & 8.2 & 43.3 & $100(\mathrm{n}=134)$ \\
\hline GVM3 & 5.3 & 35.3 & 6.0 & 12.0 & 41.4 & $100(\mathrm{n}=133)$ \\
\hline GVM4 & 5.9 & 37.8 & 3.0 & 12.6 & 40.7 & $100(\mathrm{n}=135)$ \\
\hline GVC5 & 74.1 & 18.1 & - & 2.1 & 5.6 & $100(\mathrm{n}=143)$ \\
\hline GVM6 & 30.4 & 47.8 & 5.1 & 9.4 & 7.2 & $100(\mathrm{n}=138)$ \\
\hline GVM7 & 5.8 & 43.5 & 15.9 & 24.6 & 10.1 & $100(\mathrm{n}=138)$ \\
\hline GVM8 & 11.5 & 65.5 & 4.3 & 10.1 & 8.6 & $100(\mathrm{n}=139)$ \\
\hline GVC9 & 1.4 & 40.0 & 13.6 & 37.7 & 7.3 & $100(\mathrm{n}=140)$ \\
\hline GVM10 & 7.3 & 47.4 & 13.9 & 24.1 & 7.3 & $100(\mathrm{n}=137)$ \\
\hline GVM11 & 59.6 & 34.0 & - & 2.8 & 3.5 & $100(\mathrm{n}=141)$ \\
\hline GVC12 & 32.0 & 48.4 & 1.6 & 5.5 & 12.5 & $100(\mathrm{n}=128)$ \\
\hline
\end{tabular}

Source: From the research survey in 2003

Graph 4.1: Performance rating of the Governors

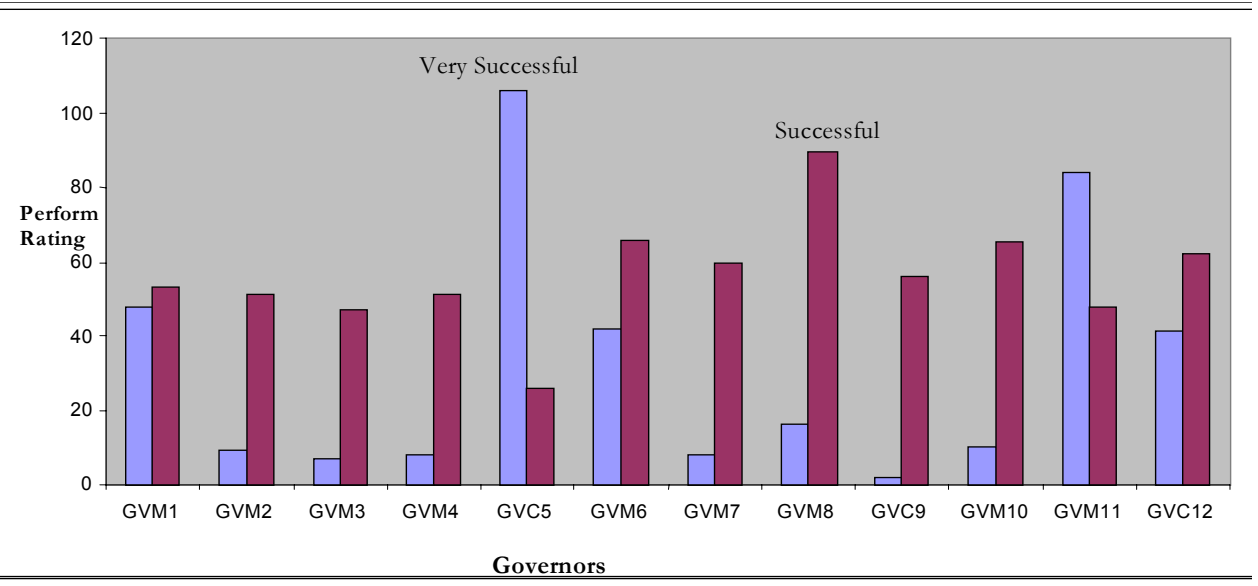

Source: From the research survey in 2003

In Graph 4.1, the level of success in the performance ratings of GVM1, GVM6 and GVM8 are relatively high. These Governors are noted for having close working relationship with the bureaucracy. These leaders carried the bureaucracy along in their decision-making process and the level of governmental capacity was equally challenged and improved upon. GVM7 and GVM11 made selective use of the bureaucracy - a situation that led to their having great success in only certain areas of government. However, one may say that GVM11 was rated very highly. This researcher is of the opinion that the high rating given to GVM11 is relative. Before his tenure, GVC9 and GVM10 had no major public service delivery achievements and the bureaucracy during their tenure was not following any particular public policy. When GVM11 came into governance, he tackled the issue of roads and security which were the major social problems confronting the state at that time. Any improvement to these public services in this period would have been rated very highly. Secondly his governance was more 
recent than that of Governors GVM1, GVC5, GVM6, or GVM8 who did exceptionally well for the state.

GVM7 and GVM11 were noted for selective participation, which gives success in certain areas of performance but always breeds contentions in the bureaucracy. According to DSI, "this leads to preferential treatment, struggling for positions, low staff morale, destruction of esprit de corps and ultimately, loss of institutional capacity and low performance of government". GVC12 also demonstrates this lack of participation of the bureaucracy in the reinvention of government through the involvement of private initiatives in governance. His recorded successes in certain areas correspond to his performance rating. However, one can still argue that the relatively high rating is due to the incumbency factor.

In assessing the performance of the various leaders that have governed Lagos State, certain issues come to the fore including personal qualities, institutional capacity, policy thrust and the participation of the bureaucracy. Lagos State's experience with military and civilian regimes do not confirm beliefs that democratic leaders are more transparent and open, with a focus on public policies for the common good of the people than military leaders.

According to Fukuyama, (2004:37), "It has become much more fashionable in recent years to argue with Sen, (1999) that democracy is both an object of development in itself and a means toward economic growth. There are a number of reasons for this argument. It is clear, for example, that it is not authoritarianism per sé that determines economic outcomes but rather the quality of the authoritarian leaders and the technocrats advising him or her." The thrust of the argument of the research is that although military regimes do not have any legitimacy, the ability of a military/authoritarian regime to perform relatively better than a democratic one may well be closely related to the personal qualities of the leader. Additionally it will depend on the governmental capability of the bureaucracy advising the leader. The next chapter examines the role of political leaders and their influence on the institutional capacity and performance of the Lagos State Civil Service. 


\section{Institutional Capacity and Public service Performance}

The qualities of political leaders play an important role in the governance and bureaucracy of the public service. Equally important is the institutional capacity available for the effective performance and reforms of the public service (Manning, 2001; Girishankar, 2000; World Bank, 2000). It is clear from the preceding chapter that the type of regime does not necessarily determine public service performance. Some of the main contributing factors are the personal qualities of the political leaders, institutional capacity, policy thrust, and participation of the bureaucracy. This chapter deals with the influence of the political leaders on the institutional capacity of the Lagos State Civil Service, and the subsequent effect on its performance. The chapter examines the influence on the following three factors:

- Human Resources Management

- Finance and Economic Policies

- Organizational Structure

\subsection{Human Resources Management Policies}

The main aim of human resources management in an organization is to use its people effectively to achieve its stated goals. This includes the recruitment and retention of quality staff through adequate motivation combined with appropriate training policies for their improvement. Environmental phenomena such as politics, economic and socio-cultural factors, however, influence the HRM practices in organizations. From our study of human resources management, it has been observed that there is no 'one best' approach, but managers develop or adapt strategy in relation to their socio-economic context.

\section{Relationship Between Political and Administrative Leadership}

In the study of public administration, there have been two schools of thought on the dichotomy between politics and administration in any governmental systems. According to Adamolekun, (1998:13-14), the first school believes that "politics and administration are two distinct spheres and that each has its own group of functionaries" ${ }^{\text {"61 }}$. The second proposition says, "a rigid distinction cannot be maintained between public administration and the policymaking or politics" ${ }^{\prime 62}$. However, a line of convergence exists between these two thoughts. In a democratic dispensation there are two groups of people in the executive arm, the first being "elected temporary political officials" that continue to serve as long as they enjoy the votes of the electorates. The second group consists of "officials who are appointed into permanent (career) service which is expected to serve successive sets of political officials" Adamolekun, (1998). Almost all the Western democracies accept this as a rule of law, although the old Soviet-block communist states differed in certain respects.

Another type of governance is the military regime as was the case for most of Nigeria's time as an independent state. The dispensation lacks electoral legitimacy. The military comes

\footnotetext{
${ }^{61}$ This based on Woodrow Wilson's seminal proposition of 1887.

${ }^{62}$ Check P. Appleby, Policy and Administration, Alabama, University of Alabama Press, 1949.
} 
into government through the power of the gun and their period is indeterminate. Regimes can be forced out of power through coup d'état and counter-coup, or through political resistance of the people, whereby they make the nation ungovernable through series of strikes and violent demonstrations.

During the colonial era in Nigeria, the executive, legislative and judicial powers were invested in the hands of the colonial appointees. This led researchers and policy-makers to term this system, "authoritarian system of government", "dictatorship" or "administocracy" (Adamolekun, 1998). After independence in 1960, Nigeria adopted the British Westminster model, although a quasi-parliamentary system had already been in place since 1952. During the First Republic in Nigeria, the electorates elected people into parliament to represent their interest. The majority party in each parliament picked the cabinets that were responsible for overseeing the party's policies or manifesto. The permanent civil servants on the other hand helped the political leaders in the formulation and implementation of these policies. The civil servants at this period were noted for their political neutrality, anonymity and impartiality. Between 1960 and 1966, the bureaucratic system was regarded highly within the Commonwealth. Regardless, in 1966 the military took over power.

As implied, during a military regime, military rulers take over the executive and the legislative powers. Adamolekun (1998) did an extensive work on politics and administration in Nigeria. He divided the period of military rule in Nigeria from 1966-1979 into four phases, namely:

- January 1966 to May 1967 (the period of a military-bureaucratic diarchy) A phase whereby the military rulers became political leaders and the higher civil servants aided them in the execution of their roles. They were rewarded with membership into the political (military) Executives of the Regional and Federal Government. The civil servants occupied "very prominent positions" and they were identified with "partisan political debates".

- June 1967 to 1970 (the civil war) the restructuring of the Federal Republic of Nigeria into 12 States in a bid to stop the secessionist plan of Ojukwu and to legitimise the military regime. Prominent civilian leaders, mostly ex-political leaders, were invited to join the Federal Executive Council, and they led Ministries and Departments as Ministers and Commissioners. Higher civil servants continued as confidential advisers on governmental policies. The rules of political neutrality and anonymity were set aside as the main goal was to preserve Nigerian unity.

- 1970 to July 1975 (the 'military-bureaucratic complex') emergence of super- Permanent Secretaries as "members of an inner caucus of policy-makers around the Head of State". They developed the 1970-1974 national development plan. The economic policy during this period enriched some of the higher civil servants and they could no longer lay claims to being propertyless, a hallmark of both classical and Marxist bureaucracy. The 1974 decree strengthened the powers of the administrative leaders to the chagrin of other professional colleagues and academia.

- July 1975 to September 1979 (military-led consensual government) The purge of the public service in July 1975 affected many higher civil servants and might have been influenced partly by "the arrogance of administrative powers." After this, the military made genuine efforts to involve every "strategic elite group" in the governance of the nation. In line with its promise, the military returned power to democratic governance.

After this, the military handed over power to a civilian government. The Second Republic, from 1979-1983, adopted the US presidential system, but this Republic was noted for its lack of restraint, self-discipline and moderation, and this gave the military the opportunity to come back into power from 1984-1999. The Third Republic was very brief between 1991-1993 with a military Head of State that "stepped aside" in August 1993 after many agitations from the citizens and imposed the civilian Head of State of Chief Ernest Shonekan between August - 
November 1993. The military came to power again till 1999. The Fourth Republic started in Nigeria from 1999 to date.

The relationship between the political (military and civilian) and administrative leadership at the federal level is comparable to what occurred at the state level. During the military regime the military Head of State makes appointments of political leaders. The military Governors are members of the Supreme Military Council at the federal and therefore policies made at this level also trickle down to the states. However, some of the policies made during the military and civilian regimes have made public servants to loss confidence in the system. Confidence in a system is based on the expectation of the workers being met. One of the reasons is loss of political neutrality between the civil servants and their military and civilian leaders.

Salisu (2000) opines that politicians' interference in everyday life of the civil service must be reduced in other to restore confidence in the system again. As noted earlier, the relationship between the military and the administrative leadership in Nigeria has a very complex political history. The military think that it is their sole responsibility to run the government, while the role of the bureaucracy is advisory. This is backed by "Decree No.1 of 1966" which vested all executive powers of the state in the military Governors. The tacit understanding that the success or failure of the military administration rested squarely on the military Governors provide them with justification, if not an excuse, to treat official advice and procedural rules and regulations with scant regard" Adebayo, (2001:80).

On the relationship between civilian and administrative leaderships Balogun, (2003:6) summarising the thought of (Soneye and Balogun, 1981; Wamalwa, 1986:66-68) says, "If career officials do not think highly of partisan politicians, the feeling among the politicians tend to be mutual. The latter cannot understand how anyone could be trusted with power (or even authority) who has taken no risk seeking grass root support, and who, for that very reason is out of touch with the "reality" on the ground".

The study noted that the above observation was in general terms as political leaders sometimes act contrarily depending on their own personal beliefs and attitudes. Some of the military Governors had implicit confidence in the bureaucracy to handle the intricacies of governance and therefore made effective use of the bureaucracy to gain useful advice in the running of government. Governors like GVM1, GVM6, and GVM8, were novices in governance although GVM8 had governed in another state. These three practised participatory leadership because they appreciated the advice given to them by their cabinets and the higher civil servants. They only acted contrary to advice when they felt strongly otherwise or when the decisions of the Federal Government overruled that of the state such as the cancellation of the metro-line by GVM6 ${ }^{63}$. Although GVM3 and GVM4 were also participatory, they only had one year in government for their tenure to be effective in all areas of governance. The period of GVM10's governance was more of peace mission given the times ${ }^{64}$.

Military Governors like GVM7 and GVM11 had governance experience from other states. They did not adopt the conventional decision-making process of calling meetings of Departments, Units or Agencies to discuss problems or issues they felt strongly about. Instead, they had a clique or inner circle about which Adebayo, (2001:81) aptly quoting Thomas

\footnotetext{
${ }^{63}$ The building of the metro-line was conceived by GVC5 in order to alleviate the horrendous traffic congestion of Lagos State. But the project was stopped by GVM6 immediately GVC5 was removed from office in 1983.

${ }^{64}$ This was a very turbulent time of Nigeria's political history. Nigerians at this period were tired of the military and wanted them to return to the barracks. He was Governor (1993-1996) during the period when General Sanni Abacha was Head of State, and that time was noted for its human rights violation, arrest of opposition activists that led to several violent demonstrations and strikes. So he spent majority of his time in pacification of the Lagosians.
} 
Kanza $^{65}$ said: "This new breed of men and women do more to influence the leader's decision than his Ministers or official technical consultants. Because they have unlimited access to the "boss", these members of the intimate clique form a kind of 'invisible arm' of the State providing their special services in addition to the official ones...". The level of participation the military leaders give to the administrative leaders can be seen in the level of robustness of their success in governance.

\section{Relationship Between Military and Administrative Leadership}

GVM1 saw the dedication and the experience of the few existing staff and he used their expertise to the fullest for the establishment of Lagos State. According to Shodipe, (1997:29) GVM1, "a man who appreciated the art of gradual maturation was an involved presence in all these deliberations. But he was never intrusive. He believed in his men, guiding them from afar with subtle enlightenment. He was also a learner too, resolved that what is inherent in good leadership is not only service to the people but also the growth of the man at the helm". The civil service under GVM1 was apolitical because the crops of civil servants at this time were disciplined and the remuneration was good. The esprit de corps was first-rate. There was no time for politics.

According to RSSG "both political and the administrative leadership had a mission and a vision. They were the vanguard for the creation of Lagos State. They wanted independence from the old Western region. They wanted to disprove the intellectual locked up thinking that Lagosians are flamboyant and high spirited, but that they are capable of building a viable State". GVM1, his political cabinet and the bureaucracy worked tirelessly to build and enhance the growth of the State. Shodipe, (1997:33) said, "He built the Lagos State Civil Service from an awkward virginal beginning and transformed it into a highly efficient lock-step machinery of governance which has since spawned hundreds of self-sustaining parastatals whose earnings continue to swell the revenue of the state, easily making Lagos the richest and the most viable state in the Federation". His relationship with the administrative leadership was fantastic for the eight years he was at the helms of affairs.

GVM2 exhibited good self-discipline and moral rectitude; and was very hard working but he was not challenging or visionary. As well, he did not have the charismatic comportment of GVM1. He had a cordial relationship with the bureaucracy but he did not effectively utilise the institutional capacity at his disposal. Many of his programmes and policies lacked good judgement and caution, such as the take over of all secondary schools from voluntary organizations and the construction of the incinerators. His other programmes were just mundane. The bureaucracy works according to how much it is challenged, but there was a good working relationship between GVM2 and the administrative leadership.

GVM3 came into the governance of Lagos State with the aim of leaving his proverbial footprint in the annals of the state. Unfortunately, he was removed from office after one year before most of his programmes could be established or his ambition realised. He respected the bureaucracy and there was a good working relationship between him and the administrative leadership. GVM4 came to rule Lagos State with one objective, which was to

"prepare Lagos State for civilian rule, that is, have elections and hand over to a civilian government".

The essential policy of GVM4 was therefore to have a successful democratic transition. He gave the bureaucracy its due respect and used it effectively for the return to democratic rule. Public servants were made electoral officers and significant efforts were made to minimize political partisanship.

\footnotetext{
${ }^{65}$ T. Kanza, unpublished memoirs, quoted in The Demigods by Jean Lacouture (London: Secker \& Warburg, 1971). Thomas Kanza was a foreign Minister in the Government that succeeded Lumumba's in Zaire.
} 
This Governor is generally thought to have given good leadership in this aspect. However, other aspects of governance were relegated into the background and the civil servants were merely engaged in routine work without much inspiration and challenge from the political leadership. Therefore, when the researcher asked GVM4 for his thoughts on other aspects of governance, he said,

"There was no time for that. We were just busy preparing the state for the civilian rule."

His lack of achievement in the other areas of governance was not due to lack of capability on the part of the bureaucracy but his failure to use it. Aside from this, he had a good working relation with the members of the higher civil service.

All the informants were unequivocal on the fact that GVM6 was one of the most participatory amongst the military Governors. He came into governance with a vision of transforming the state into one of the most beautiful in the federation. His strategy was to mobilise both the government and the governed into participation. His mission was to introduce quality into every aspect of government. He had foresight for good governance and knew he could not do it alone. He carried the bureaucracy along with his vision, and continued with the regular meetings earlier instituted by his civilian predecessor in order to be updated about the state and stage of execution of his programmes. According to DSI, "The vision of a leader has a direct impact, whether positively or negatively. The ability of the government to effectively implement, monitor its programmes, and keep its executive in focus is very important. The Governor plays a major role. If he allows things to slip out of his hands he will not be able to achieve his goals."

Recollecting, RPSI said, "GVM6 was in charge. He knew everything that was going on. He would go unannounced to check on work that was being done. He worked tirelessly." He challenged civil servants, stimulated them and expected them to proffer solutions. He recognized and challenged the capacity and skills within the bureaucracy and it yielded results, although his tenure was only for two and a half years. He transformed the physical environment of the state and the surrounding area was gradually becoming beautiful when compared to the past. He was participatory and he made an effective use of the bureaucracy. He believed in the capacity of the bureaucracy to carry out his programmes, and made them to feel appreciated and important.

For example according to PRSIV "GVM6 recognized that he could not appoint everybody as Permanent Secretaries, so he introduced the coordinating directorship role that was at par salary-wise with the Permanent Secretaries." This gave these "senior" Directors the impetus to work diligently and be committed, knowing that their contributions were recognized. He had a good working relationship with the middle-level management who attended some of the meetings with the Governor in order for them to learn and be involved in the decisions of government. This important synergy between political leadership and the bureaucracy may well contribute to the acknowledged success of this Governor. According to the Lagos State Ministry of Information document ${ }^{66}$ on GVM6, "Thus the administration of GVM6 having consolidated the achievements of GVC5's regime, embarked on the enormous task of improving and upgrading social facilities within the limits of available resources".

According to RPSIII, "GVC5 and GVM6 were very involved in governance but by the time it was GVM7's tenure he slowed down the momentum. Participatory governance was not his style." The relationship between GVM7 and the higher civil service was very strained. In the discussion with the researcher, GVM7 felt that he was misunderstood. According to him,

\footnotetext{
${ }^{66}$ Lagos State Ministry of Information - "Group Captain (Later Commodore) Gbolahan Mudashiru, Military Governor, Lagos State, January 1984- August 1986”
} 
"In reflection, there were areas when I was insisting on maintaining the standards of the environment. People thought that I was arrogant. The environment had degenerated. Some people were afraid of me because I was too demanding and I wanted the highest standards. I believe that I did not have all the time in the world. So I tried to drive people to the highest limits. Also, I believed that the civil service needed some fresh ideas, so I tried to select people who had mixed experiences. I believed they should help with their expertise".

This action of the Governor brought considerable acrimony among the higher civil servants. Some staff were promoted to positions above their former superiors. This was a disruption to a system used to strict rules about promotions and advancements ${ }^{67}$. Commenting on this, DSI felt that "there was a shift of focus on the part of the leadership. Specifically, in 1986 during GVM7's era civil servants started struggling for positions. The system was encouraging the so-called high-flyers, but it was actually preferential treatment. Leaders were not training the junior staff but were maligning one another. It was a period of divide-andrule. Furthermore, the economic situation was not very helpful." In response to the economic conditions particularly the biting inflation, staff started lobbying for positions that would give them additional remuneration to their salaries.

According to PSSI, "Significant changes took place during this period. In the past, the civil service was like your home. One had access to ones immediate superiors. Learning was by example and asking questions. Esprit de corps was very high. The challenge for the civil servants was to build the foundation for tomorrow. Staff stayed late into the night to get work done. In 1986, the then military Governor said that if a staff member stays beyond the official closing time the person is stealing something ${ }^{68}$. This created a psychological set-back as no one wants to be perceived as 'stealing' or doing something untoward. Officers refrained from working beyond the normal working hours." His predecessors GVC5 and GVM6 customarily both worked beyond normal office hours. Officers had started cultivating the habits of hard work again after the practical inaction of the civil servants before these two Governors. The relationship between GVM7 and the administrative leadership was very tense, although the Governor believed that his problems were with the

"female Permanent Secretaries who had parochial interest. They always criticized.

They liked the campaign that I never know much about Lagos State because I was not a Lagosian".

By the time GVM8 came into governance, the relation between the political and administrative leadership was strained. Even within the bureaucracy, different camps were building up caused by suspicions amongst the staff. The ability of the new leader to mend the bridges was crucial. GVM8 came into the governance of Lagos State determined to enforce the norms of military precision and timeliness. He was conscious of the power of the bureaucracy and knew how to work with the civil service to realize his programmes. At this period, the bureaucracy was demoralized. Commenting, DSI said, "The staff welfare was practically nonexistent, and this affected the morale of staff. With economic stagnation and devaluation of the Naira the staff were demoralized. Esprit de corps was destroyed. During GVC5's era, the environment was very good. There was fair play and discipline. However along the line the political leadership lost focus." Box 5.1 contains GVM8's view on his relationship with the administrative leadership.

GVM8 knew that he needed somebody well-respected who understood the working of the bureaucracy to become the Secretary to the State Government. He was the first Governor

\footnotetext{
${ }^{67}$ Lack of transparency in the promotion or acceleration of these officers led to acrimony and accusation of favouritism on the part of the Governor.

${ }^{68}$ This is a situation in which a leader imposed his personal ethos of rigid observance of working hours on the entire system of bureaucracy. This impact was immediate and had negative and long term effect on behavioral performance
} 
to appoint a woman to this position. She was highly regarded by the bureaucracy and all the informants spoke highly of her. This singular action of GVM8 reinforced the relevance of the bureaucracy and fostered renewed trust between the administrative and political leadership. According to an article by the Lagos State Ministry of Information ${ }^{69}$ on GVM8, "The ability to exploit and harness its human and material resources scored his administration a lot of distinction during his tenure". In the interview with GVM8, excerpted in Box 5.1, he spoke plainly about the great respect he had for the civil servants. He had a good working relation with the administrative leadership and in turn, they helped him pioneer a significant number of organizations and programmes for which he took credit.

\section{Box 5.1: Governor GVM8's views on his relationship with the Administrative Leadership}

I have a deep respect for the crops of the civil servants that worked with me, they are the best in the Federation. The present administration could still tap from their knowledge. The Head of State General Babangida said that I had the best. They toiled night and day that my aims and objectives might be realized. We were like a family. If they were not I would have told them because I am very blunt. We inherited from the old Western Region Civil Service. The old Western Region used to have the best. I think I have the right to say that. If I have the same opportunity again, I will still use the same group.

My government encouraged political neutrality, but I am not sure now. Every human being is a political animal; they may look neutral and may not take active part in politics. But I know there must be some leaning, although they may not carry party cards and so on. However, during my regime, they were happy to do the job because they have job security. It was nice to keep them outside active politicking. We encouraged it. We use the civil servants and teachers for election; if they had been partisan, we would not have the best election. If they were to take active part in politics the result would not have been so. I still believe we should go back to that period. If the civil servant is afraid of his future career he will not put in his best. Maybe because of my profession, the army, we have the welfare of our workers in mind. I made sure that everybody from the ranks of Directors upward could secure their future. The civil servants now have houses in Victoria Island and Ikoyi. These are choice areas of the state. What ever entitles a soldier or a businessman, it entitles these crops of officers to also have. I gave it to them and I do not regret giving it to them. I am happy that those who worked with me were happy. It is my wish that other Chief Executive will follow suit. They are happy wherever they are now. 5\% of the houses built by the Lagos State Property Development went to the staff. They planned these houses. I believe they should own property. I created Lagos State Building Corporation (LBIC) for the purpose of borrowing and building their own houses.

First, the welfare is no longer there. Therefore the commitment I enjoyed is no longer there because they are not sure of their career and future. This will not help the country if the government decides to sack staff.

Second, there should be training. The auditorium was built for grade level 12 officers and above to attend courses. There is a need for the government to emphasize training and retraining of staff. There should be a continuous training for the staff.

Third, the salary should be looked into. The salary should be commensurate to the living standard. The welfare of the civil servant should be paramount. People should be able to look into the future with confidence. The civil servants should be made to see that they have future in their career. There should be welfare scheme especially housing so that people will know that when they retire they will have somewhere to put their heads.

Fourth, the pension is not forthcoming. Pension must be adequate. Staff will start trying to fend for themselves if they see the way the retirees are being treated. The Chief Executive should give them good environment to perform including the schooling of their children.

Source: The researcher's interview with Governor GVM8 in 2003.

GVC9, a civilian Governor who isolated himself from the bureaucracy, succeeded GVM8. After him came GVM10. The relationship between GVM10 and the bureaucracy was nonexistent; his Secretary to the State Government ${ }^{70}$ pulled the staff together. According to RPSIII, "GVM10 tried to have meetings with the Heads of Departments and Ministries once in a while in other to garner their support. His tenure was characterized by perpetual civil un-

\footnotetext{
${ }^{69}$ Lagos State Ministry of Information - The Rasaki Administration in Lagos State, July 1988-December 1991"

${ }^{70}$ The Secretary to the State Government (military regime) and Head of Service (civilian regime) provides leadership and direction for the civil service through inspiration and motivation. He ensures the efficiency of the service through staff development and training, and maintains high morale through the adherence to rules and regulations, and code of conduct of civil service.
} 
rest". In his contribution, RSSG believed that GVM10 $0^{71}$ devoted a large proportion of his time trying to pacify the people. GVM10 can therefore not be credited with knowing the capacity and the capability of the Lagos State bureaucracy because there was no real working relationship between them.

By this time, there was apathy and lethargy among the civil servants and the populace was disillusioned. There was no confidence in government or its ability to provide public services. Given the prevailing socio-economic condition, any leader that makes even marginal positive difference is likely to receive high rating. GVM11 came into governance at this period. Unlike GVM1 and GVM6, his style was not participatory. Although at this period there was the general impression that the civil service was declining, certain Departments and Ministries still perform their duties to the best of their abilities with the available resources. Commenting on this, RPSII believes that "although, there is a decline in terms of productivity, discipline, commitment and industry, a lot depends on who is at the helms of affairs. Consistent good leadership will lead to productivity. One should not make a blanket statement here; because some heads of organizations who are ingenious and know what they are doing still make things work." For example, GVM11 made use of the Lagos State Direct Labour Agency for the massive road reconstruction and rehabilitation carried out during his tenure. GVM11 gave this agency the moral and material support it needed and it performed well.

The Governor was noted for hard work and intelligence, but the perception of the bureaucracy is that he concentrated his energy on the development of selected areas to the detriments of others. A number of senior civil servants affirmed that he supported hard work and always appreciate the efforts made by people. However, not all the administrative leadership could comment on his leadership style because they did not know him that intimately. However, the overall impression is that he used the bureaucracy well for the implementation of his programmes and the respondents rated him very highly on his ability to deploy the knowledge and skills of the civil service for positive public purpose.

The survey asked whether the military Governors have confidence in the civil servants to implement their programmes effectively. $86.5 \%$ of respondents said yes, whilst $13.5 \%$ said no. This response was not surprising; research shows that the majority of the military Governors relied on the civil servants for the implementation of public policies. In Table $5.1^{72}$, $32.7 \%$ indicate that the military have confidence in civil servants, $16.8 \%$ believe that they encouraged the civil servants to do their jobs. $19.5 \%$ also believe that the military can relate to the civil service because they too are used to the command system.

\footnotetext{
${ }^{71}$ This was a very turbulent time of Nigeria's political history. Nigerians at this period were tired of the military and wanted them to return to the barracks. He was Governor (1993-1996) during the period when General Sanni Abacha was Head of State, and that time was noted for its human rights violations, arrest of opposition activists that led to several violent demonstrations and strikes. So GVM10 spent the majority of his time in pacification of the Lagosians. He did not have the opportunity to start any new project. Although he tried to complete some of the uncompleted projects he met.

${ }^{72}$ In retrospect however, the result would have been more interesting if the researcher has been able to collect the rating of the military Governors' confidence in the bureaucracy on individual basis, because the level of confidence depends on the leadership style of the man at the helm. While some leaders trust the institutional capacity of the government, some were discriminatory and selective.
} 
Table 5.1 Do military Governors have confidence in civil servants to implement their programmes effectively?

\begin{tabular}{|c|c|}
\hline Response & $\begin{array}{l}\text { Percentage } \\
(\mathrm{N}=113)\end{array}$ \\
\hline 1. Yes, the military have confidence in civil servants & 32.7 \\
\hline 2. Yes, Military administration relies on command structure & 19.5 \\
\hline 3. Yes, they encourage the civil servants to do the jobs they were employed to do & 16.8 \\
\hline 4. Partially yes, because Civil service is not the military & 4.4 \\
\hline $\begin{array}{l}\text { 5. No, the administrative approach and the training of the military are far different from } \\
\text { the Civil service }\end{array}$ & 6.2 \\
\hline 6. No, because of self interest & 10.6 \\
\hline 7. No idea & 9.7 \\
\hline TOTAL & 99.9 \\
\hline
\end{tabular}

Source: Researcher's survey in 2003

\section{Relationship Between Civilian and Administrative Leadership}

Three civilian Governors have been at the helm of the Lagos State Government. GVC5 was the first civilian Governor to rule the state. According to GVC5,

"Yes, I believe that I had the best civil service in the country and it was eminently capable to affect the policies of my government. My government encouraged impartiality by the civil servant. A civil servant cannot be neutral. He has to be committed to the execution of the policies and programmes of the government of the day. He is not partisan and is not expected to carry a party card."

In the study, respondents rated Governor GVC5 as the most successful. He encouraged participatory governance. The populace and the staff loved him for his vision, transparency, accountability and hard work. The morale of the staff was high, meritocracy remained in place, staff was recruited on merit, promotions given to deserving officers, the pay and other incentives were good, and this positively affected the performance of the staff and his government.

Commenting on the government of GVC5, DSSI believed that "GVC5 made deliberate efforts to have service friendly policies. He encouraged the improvement of skills, and training on the job. Staff were given free hand to do their schedule. He gave staff the opportunity and authority." There was collaboration between the political and administrative leaderships. The Governor made everybody to believe that his policy was equally their own. That was why he said that he did not believe in any civil servant being neutral. He gave the Civil service "a clear sense of direction". He made the civil servants believe in themselves and boosted their morale through the monthly briefing. According to Olowu, (1990:103) "The monthly briefing with GVC5 by each Ministry (quarterly with respect to parastatals and local governments) is generally regarded as a powerful management weapon. Since each Commissioner comes with his retinue of senior management staff to these briefings, the Governor is able to assess the performance and ability of each of his most senior staff. This is said to be a powerful weapon for getting quick results."

This strategy committed the senior staff in the Ministries to their duties and made them feel relevant, as they could be called upon at any time to account for their actions. As he knew his staff, he could defend and give them credits accordingly. In his contribution, RPSI said, "GVC5 came with the idea that his Permanent Secretaries were very hardworking and should be ranked along with the federal Permanent Secretaries, and thereby insisted that they should be paid the same salaries as their mates at the Federal Government". 
One of the problems of the civilian regimes is the selection of political appointees into government. Many appointments are not because of experience in governance or educational achievements, but due to active participation and connections in politics. Recounting, PSSII said, "During the Second Republic, appointment came from the ward. The Commissioner or Special Adviser may be Chairman of the ward, without any experience whatsoever." However, GVC5 did not allow distrust or disrespect to develop between the political appointees and the higher civil servants. The monthly meeting between the political appointees and the civil servants brought them together to develop mutual respect for each other. The quality of service depends strongly on the foresight and the quality of the Governor. All the informants recalled this period of the civil service with nostalgia. A period when there was trust between the political and administrative leadership, and of great performance on behalf of the bureaucracy. A period that the citizen believed that the government was capable of providing what ever was required in terms of public service deliveries.

GVC9 is the second Executive Governor of Lagos State. He had laudable programmes but lacked the political and managerial will to implement them. He came into governance with the mindset that

"corruption is endemic in Nigeria and I have to fight it my own way"

He made himself to be unapproachable to the civil servants because of his lack of confidence in them. According to Shodipe (1997:160), "Only few trusted aides knew where he could be at any particular time. This provoked rivalry and even animosity among his confidants who jostled for position and influence. The result was a seeming incoherence and paralysis..." During this period, the civil service was in an indeterminate state. There was a great distrust between the political and administrative leadership. There was no coherence in the implementation of his programme.

RPSI said, "During the civilian era, appointments were political. GVC5 made a GL12 73 officer to become a permanent secretary. GVC9 did similar things. The career status and seniority were not put into consideration during appointments of civil servants. Seniors were serving under juniors and this brought a major decline in the performance of staff. No more respect or commitment. Positions did not command respect again. The post of Permanent Secretary was ridiculed with impunity. Permanent Secretaries were disregarded and it was rubbing off on the production and the performance of the civil service."

Contractors capitalized on this weakness and defrauded the government, a near impossible situation during the regime of GVM6 when the ever-efficient PPBB always monitored government's programmes. Civil servants started jostling for promotion and choice postings through political connections. There was a great disillusionment amongst the staff. The civil service started to lose its focus. The performance of the civil service that rated very well a decade earlier had started to decline. GVC9's regime rated the lowest.

Governor GVC12, the third Executive Governor of the state, came into governance with a plan to modernise and reorient the civil service for better results by removing complacency through the injection of new blood and ideas into the system. He thinks that the poor performance or unprofessional conducts of civil servants are due to their "not willing to change" and sought to reinvent the government using NPM modalities, which his administration has introduced. According to him, they are not

"Ready to face initial hardship for a lasting growth and progress. Not seeing the longterm vision as their own vision, and not asking themselves how can they make the system better. They complain and (do not) make contribution in terms of ideas. They must change their attitude to build tomorrow, today and have the courage to discuss and

\footnotetext{
${ }^{73}$ GL12 is the last grade of the intermediate management level. Usually, most Permanent Secretaries are selected from the Directorate level of GL15-GL16.
} 
have dialogue. Deliberate and think over the interest of the state instead of their own. The resources of the state are for all and not only for the civil servants".

This period witnessed the employment of a great number of staff with a private sector background, many who came with a different understanding as to how the civil service should work. Some of these people are trained abroad and the existing staff refer to them as "American specs" that is, American specifications, hoping that they will energise the civil service with their expertise and experience. Some local employees came straight into senior management positions because of their years of experience in the private sector. The number of jobs filled in 2000 was $2371^{74}$. According to PSSII "When I joined the Lagos State Government in 1979, I was given an Administrative Officer position, then it was called Senior Assistant Secretary, in spite of the fact that I graduated in 1972 and I had worked in the United State of America before coming home to join the civil service. I was graded like that because experience from the private sector was not regarded then". At that period, there was a strict adherence to rules and regulations regarding employment.

In his contribution PSSIII said, "The recruitment of some inexperienced workers at the top management level has affected the level of effectiveness in the service. Many do not have cognate professional or administrative experience. Due to nepotism, people are employed at level GL16, and staff under them have to train them. Grade levels $8-10$ are training positions. This frustrates and wears down the existing staff. These affect the quality of service. A lot of workers are no longer dedicated." Commenting along the same line RPSIII said, "GVC12 relies more on his cabinet than his administrative leadership. His Permanent Secretaries are not involved in governance, instructions are doled out to them, and they read what is happening in the government from the newspapers. This is not good for the morale of the Permanent Secretaries. There are so many incursions of non-civil servants in the service and they came to extract what they could get from the system, in view of the prevailing economic hardship. These people are politically motivated and they operate in a system where there is no accountability or rule of law. The system cannot work where there is so much nepotism and corruption." Many of the appointments were not based on merit or known achievements of the beneficiaries ${ }^{75}$. This policy of government has started to have adverse effect on the institutional capacity.

The emphasis on party patronage according to RPSII does not augur well for the civil service. "Staff now secretly play politics and carry party cards. This does not help for much progress. The confidence and trust of the people in the system are being eroded. People now pretend and no longer give good advice in order to maintain their positions. Staff now dance to the tune of the government in power." In support PSSI said, "The government needs to focus on the area of political appointments. There are too many to the detriment of the service." This period reflects the greatest strain between the political and administrative leaderships, a situation that is not helping the performance of the bureaucracy. Although this regime currently rates highly, this is at variance with the comments and some other ratings given this regime at other times. Is it the incumbency factor working here? ${ }^{76}$

Commenting on this GVM8 said,

\footnotetext{
${ }^{74}$ Employment progression in the Lagos State Civil service will be discussed later under recruitment.

75 This is contrary to the meritocratic system proposed by Weber for effective running of the Bureaucracy. A merit system must be based on recruitment, employment and promotion based on qualifications and achievement, permits no favouritism, no nepotism, and promotes unbiased decision-making. The New Public Management goes further to emphasize that appointment must not only be on internal labour market, but a shift to "public employment from permanency and standard national pay and conditions towards term contracts, and performance-related pay (PRP)" (Pollitt, 1996). The NPM believes that competition from outside will remove rentseeking and complacency from the existing staff. However, appointments must be based on credibility and transparency.

${ }^{76}$ GVC12 was the Governor during the period of study. Ratings by serving civil servants may be coloured by fear of reprisals.
} 
"The civil servants are victimized if they do not toe the lines of the politicians. Many have become sycophants and they tried to stay loyal to the politicians because they are afraid of losing their jobs. They are scared to give quality advice and this is making the civil service to be ineffective".

In his own defence however, GVC12 said,

"I never victimized anybody that does not have political affiliation. I never mobilize the civil servants to go and vote. I never question them on it. I used the same persuasive method not intimidation. I love their neutrality they should be able to make up their own minds".

The survey asked if the civilian Governors have confidence in civil servants to implement their programmes effectively. Of the respondents, $60.7 \%$ said yes and $39.3 \%$ said no. A further breakdown on the rationale behind this is analysed in Table 5.2; 33.1\% of the respondents indicated that civilian Governors regard the art of governance as the sole responsibility of civilians/ politicians. A further $27.3 \%$ believe that civil servants are lazy and too many, while $14.9 \%$ opined that civil servants are fraudulent. Only $5 \%$ believe that civil servants are competent to implement their programmes.

Table 5.2 ${ }^{77}$ : Do civilian Governors trust the civil servants to implement their programmes effectively?

\begin{tabular}{|c|c|}
\hline Response & $\begin{array}{c}\text { Percentage } \\
\text { (N=121) }\end{array}$ \\
\hline 1. The art of governance is the sole responsibility of the civilian/politicians & 33.1 \\
\hline 2. Civil servants are lazy and too many & 27.3 \\
\hline 3. Politicians regard civil servants as fraudulent & 14.9 \\
\hline 4. No idea & 12.4 \\
\hline 5. Not applicable & 7.3 \\
\hline 6. Civil servants are competent & 5.0 \\
\hline TOTAL & 100 \\
\hline
\end{tabular}

Source: Researcher's Survey in 2003

Given this impression, the civilian regimes, especially the current one, witness the greatest conflicts between the existing and new staff. The atmosphere was cordial during the period of GVC5 as he was able to bridge the differences between the political and administrative leaderships. The present civilian Governor has many years of private sector managerial background and he told the researcher that he believes "in the principle of reinventing governance". He embarked on the "restructuring" of the public service with large-scale retrenchment, including staff at top management level, and these were replaced with private-sector professionals and technical staff as solutions to the skills gap. This he hopes will encourage new ideas and experiences of managerial techniques. The New Public Management is a strong advocate of minimal state, a condition where a large labour force is not needed to carry out public service deliveries. What the government needs are such things as improved administrative capacities, better orientation, and contractual production. However, being a civilian dispensation, instead of downsizing, this regime is noted for the highest recruitment of staff in the history of Lagos State Civil Service.

\footnotetext{
${ }^{77}$ This table should be interpreted with caution. The result would have been more robust if the researcher could have disaggregated these figures by civilian leaders given the differential shown between them. Whilst GVC 9 and 12 were very sceptical about the capacity of the civil servants and their ability to implement their programmes effectively, GCV 5 boasted about the efficiency of the civil servants to implement his programme and he made use of the institutional capacity at his disposal.
} 


\section{Recruitments}

The Ministry of Establishments and Training ${ }^{78}$, the Civil Service Commission, and the Office of the Head of Service are in charge of staff management in the Lagos State Civil Service. Ministry of Establishments is concerned with staff on grade-levels 01-07. The Lagos State Civil Service Commission conducts recruitment into the middle management cadre (Grade levels 08-12). The Commission is responsible for monitoring the performance standard of the service. Its functions include recruitment, promotion, discipline and dismissal of the civil servants. The staff management of officers in the senior management level ${ }^{79}$ (Grade levels 1317) is under the purview of the Office of the Head of Service, with the assistance of the Civil Service Commission. In the assignment of Ministerial responsibilities, the Head of Service is also responsible for the posting of civil servants from all cadres (administrative, professionals, sub-professionals and centrally-deployed cadre). It is therefore a very powerful office.

Tasks of the Ministry of Establishments and Training, in conjunction with the Head of Service (HOS), include matters relating to staff complement, grading and condition of appointment. Further, the Ministry coordinates the condition of service as related to salaries, wages and allowances. The Ministry of Establishments in conjunction with HOS, Civil service Commission and the affected Ministries should determine the specific size of a government Department or Ministry. The entire workforce of the Lagos State Public service at December 31, 2002 measured 51,221. The Post Primary Teaching Service Commission (PPTESCOM) has the highest number of staff with 22,307 (43\%), the Civil service came second with 13,285 (26\%), followed by government owned Parastatals with 7,603 (15\%), Hospitals Management Board with 7,603 (9\%), and Tertiary Institutions with 3,641 (7\%), (Lagos State Public service Manpower Statistics, 2002).

Chart 5.1: Lagos State: Staff Strength of the Public Service, 1982-2002

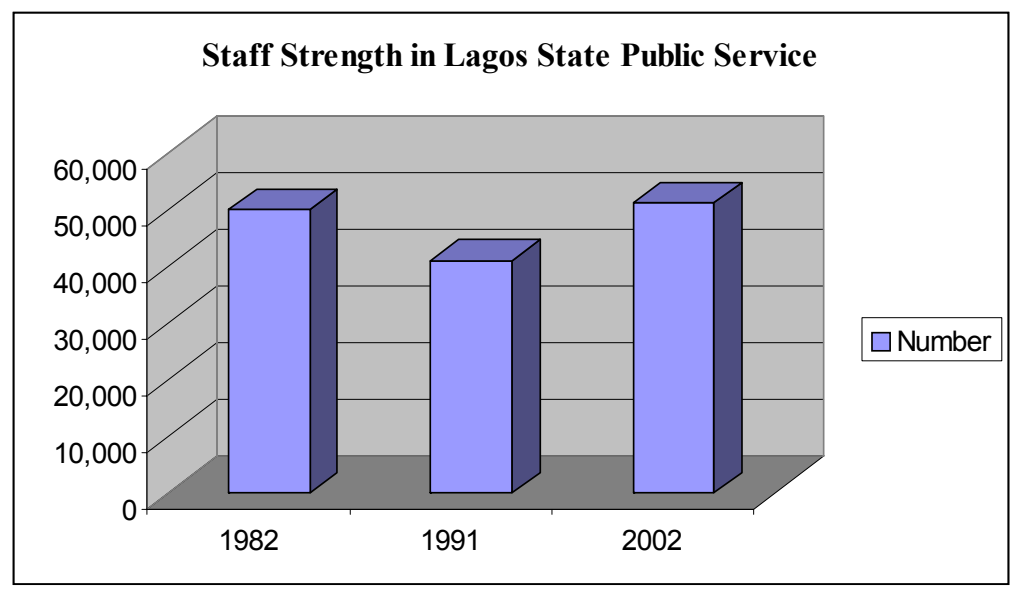

Source: Lagos State Government, Ministry of Establishments and Training (Management services Directorate), 2002, and composition of Lagos State Public service (1982) as adapted from Table 4.3, page 100 in Lagos State: Governance, Society \& Economy (Olowu, 1990).

\footnotetext{
${ }^{78}$ This Ministry has been given different nomenclature over the years like Ministry of Establishments and Service maters; Ministry of Establishments, Pensions and Training; Ministry of Establishments and Training, and so on.

${ }^{79}$ The senior management level is sometimes further sub divided to separate grade levels 15-17 which is referred to as the Directorate level.
} 
Notes: In 1982, the staff strength of Lagos State Public service is made to include the Teaching Service, Parastatals (including Hospital Management Board), and the Civil service. In 2002, the figures include Post Primary Teaching Service Commission, Civil service, Parastatals, Hospital Management Board, and Tertiary Institutions.

Chart 5.1 shows the entire work force of the Lagos State Public service between 1982 and 2002. The staff strength was 51,013 in $1982,41,045$ in 1991, and 51,221 in 2002. It is interesting to note that from 1982 to 1991, the staff strength actually decreased by about 9968 . A number of things might have caused this. The public service was losing staff through retirements (voluntary and compulsory), resignations, transfer, dismissal, and deaths. As well the military government at both federal and the state levels thrives on status quo.

In Lagos State, the military political leaders were noted for their partial freeze on recruitment, this was also mitigated by the severe economic situation in the country. The recruitment freeze led to many vacant positions. Although this helped to reduce the rate of expansion, it was not without its disadvantages. This led to a situation whereby good staff are overworked, and this ultimately leads to inefficiency, as many of them become overwhelmed with the work. This factor affects institutional expertise of some of the staff and institutional incompetence starts to develop. According to DSI, "During the Military era there was embargo on employment. New entrants were not brought in because employment was made only in trickles. The Ministries were deprived of succession planning. This affected the quality of work".

Table 5.3 aptly shows the distortion in the levels of management of Lagos State Civil service as at 31 st December 2002. The staff strength of officers in grade levels 01-06 (junior staff) was 4076, about half of those in grade levels 07-12 (supervisory cadres) who are 7970 in number. There is therefore a gap in the supervising cadre. There is also a misrepresentation between the middle management and the senior management levels. The number of staff in the senior management cadre was also 1151 . The top was very heavy to the detriment of effective service performance. The middle to senior management cadres became an inverted pyramid. This situation affected succession planning adversely in the system. In their own comments PSSII and RPSI, said that the service was becoming top-heavy and short-staffed at the lower cadres. Lobbying took pre-eminence over policies in the system because those at the top started jostling for positions.

Table 5.3: Lagos State: Levels of Civil Service Management by Gender, 31st December 2002

\begin{tabular}{|c|c|c|c|c|c|c|c|c|c|}
\hline \multirow[t]{6}{*}{$\mathbf{S} / \mathbf{N}$} & \multirow[t]{3}{*}{$\begin{array}{l}\text { Agency (Min. \& Extra } \\
\text { Min. Depts }\end{array}$} & \multirow{2}{*}{\multicolumn{2}{|c|}{$\begin{array}{c}\text { Junior Staff } \\
\text { GL 01-06 }\end{array}$}} & \multirow{2}{*}{\multicolumn{2}{|c|}{$\begin{array}{c}\text { Middle } \\
\text { Management }\end{array}$}} & \multirow{2}{*}{\multicolumn{2}{|c|}{$\begin{array}{c}\begin{array}{c}\text { Senior } \\
\text { Management }\end{array} \\
\text { GL13- consolidated }\end{array}$}} & \multicolumn{2}{|c|}{ Total } \\
\hline & & & & & & & & \multirow[b]{2}{*}{$\mathrm{M}$} & \multirow[b]{2}{*}{$\mathrm{F}$} \\
\hline & & M & $\mathrm{F}$ & M & $\mathrm{F}$ & $\mathrm{M}$ & $\mathrm{F}$ & & \\
\hline & & 2876 & 1200 & 4387 & 3583 & 697 & 454 & 7960 & $\mathbf{5 2 3 7}$ \\
\hline & $\begin{array}{l}\text { Data Not Analyzed For } \\
61 \text { Male And } 27 \text { Fe- } \\
\text { male For Lack Of Suf- } \\
\text { ficient Information }\end{array}$ & & & & & & & 61 & 27 \\
\hline & Total & \multicolumn{2}{|c|}{4076} & \multicolumn{2}{|c|}{7970} & \multicolumn{2}{|c|}{1151} & \multicolumn{2}{|c|}{13285} \\
\hline
\end{tabular}

Source: Based on data provided by Lagos State Government, Ministry of Establishments and Training (Management services Directorate), 2002.

The distortion in terms of levels of management is also portrayed in Table 5.4. For instance in 1982, the established (not actual) staffing was projected to have a ratio of 1:31 between middle management staff (grade levels 07-12) and junior staff (grade levels 01-06) while between 
the senior management level (grade levels 13-17), and the middle management staff the ratio should be 1:8. Practically demonstrated, one senior management staff is supposed to supervise the work of eight middle management staff; each of whom will supervise the work of 31 junior staff. By 2002, the actual span of control is 2:1 between middle management and junior staff, and 1:7 between senior management and middle management staff.

Table 5.4: Lagos State: Civil Service Staff Strength, December 2002 contrasted with 1982 Civil Service Establishment.

\begin{tabular}{|c|c|c|c|c|}
\hline & 1982 & Span of control & 2002 & Span of control \\
\hline Grade level & Establishment & & Actual Strength & \\
\hline 01 & 2475 & & 523 & \\
\hline 02 & 4084 & & 544 & \\
\hline 03 & 6522 & & 1079 & \\
\hline 04 & 5530 & & 1065 & \\
\hline 05 & 2019 & & 306 & \\
\hline \multirow[t]{2}{*}{06} & 1760 & & 598 & \\
\hline & & $1: 31$ & & $2: 1$ \\
\hline 07 & 1510 & & 2423 & \\
\hline 08 & 2267 & & 3417 & \\
\hline 09 & 1541 & & 1143 & \\
\hline 10 & 1106 & & 544 & \\
\hline \multirow[t]{2}{*}{12} & 588 & & 473 & \\
\hline & & $1: 8$ & & 1:7 \\
\hline 13 & 304 & & 398 & \\
\hline 14 & 239 & & 418 & \\
\hline 15 & 161 & & 147 & \\
\hline 16 & 90 & & 110 & \\
\hline 17 & 35 & & 31 & \\
\hline Consolidated & - & & 29 & \\
\hline Total & 30229 & & $13248 *$ & \\
\hline
\end{tabular}

Source: Lagos State Government, Ministry of Establishments and Training (Management services Directorate), 2002, and composition of Lagos State Public service (1982) as adapted from Table 4.4, page 101 in Lagos State: Governance, Society \& Economy (Olowu, 1990).

*Note: The actual number of staff is 13285 but data not analysed for 37 staff for lack of information.

However, if the ideal span of control as quoted by Olowu (1990:101) is 1:4 and 1:16 between intermediate to junior and senior to intermediate respectively, then established 1982 ratio compared to the 2002 actual ratios, shows a major violation to this guideline. The 1982 projection shows the junior level about $675 \%$ overstaffed and the middle management level about $50 \%$ understaffed. This situation supports international reports such as the World Bank's 1983 World Development Report that suggests that one of the problems of the public service structure in developing countries is overstaffing at the junior, and understaffing in the middle management level. This type of staffing situation usually leads to absence of adequate supervision of the junior cadre by the middle management cadre that in turn creates strain and added responsibility on the part of the senior management level. Absence of appropriate organizational structure always has a negative influence on organizational climate and performance. 
However, by 2002 the staffing situation in Lagos State Civil service is at variance with the above observation of junior staff overstaffing. An inverted pyramidal organizational structure emerges where the staff strength in the middle-level cadre is 7,970 as compared with the junior staff of 4,076. A ratio of approximately 2:1 now exists between middle management and the junior cadre so two staff supervise one junior staff. The distribution is also skewed and shows a dysfunctional proportion between the senior management and the middle management levels. The staff strength of the former is 1,151 , while the latter is 7,970 . The span of control between senior management and middle management levels is ratio 1:7, which still shows a gross understaffing in the latter cadre.

Chart 5.2: Lagos State: Recruitment in Civil Service for staff between Grade levels 08-17, 1985-2000

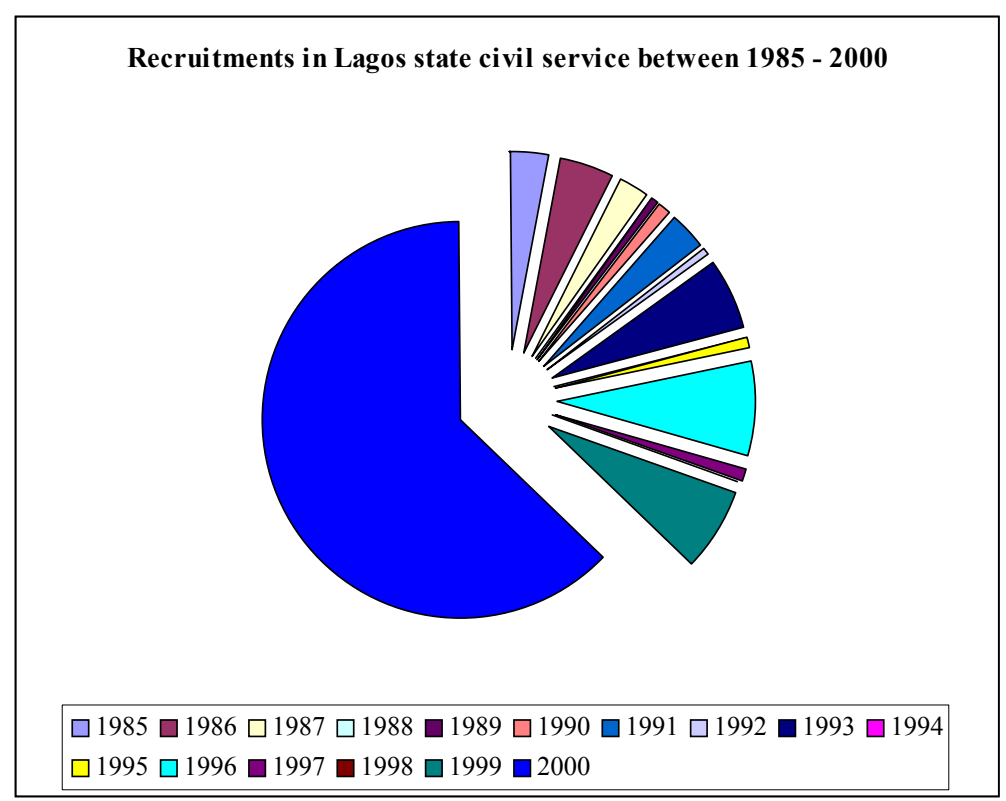

Source: Lagos State Civil service Commission Annual Reports 1985-2000

Chart 5.2 shows the numbers of the people recruited in Lagos State Civil Service from 1985 to 2002 . The chart shows that the years with greatest recruitments were 2000 and $1999^{80}$ with 2,371 and 250 staff during the period of civilian Governor GVC12. Many of the staff that joined the service during this period went straight into the senior management cadre. The second civilian Governor GVC9, made the second largest recruitment with 113 in $1991,16^{81}$ in 1992, and 224 in 1993. GVM10 recorded the highest recruitment for the military regime during this period in 1996 with 286 employments. GVM11 made the least recruitments with only 30 in 1997 and 5 in $1998^{82}$. The civilian regimes are noted for the employment of people with different cultures into the service. People from the local government and private sector come straight into the service at top managerial positions. One of the recommendations of the NPM is contractual political and accountable management. NPM believes that those who stay

\footnotetext{
${ }^{80} \mathrm{GVC} 12$ hired about $70 \%$ of all the total employment made by the different Government between 1985 and 2000 in only 2 years (1999 and 2000).

${ }^{81}$ The number of employments in 1992 was very low because the Civil Service Commission was not constituted in 1992.

${ }^{82}$ GVM11 did not give any dispensation for employment in 1998.
} 
long in the public service become self-serving, but those who have political mandate will deliver promised services to the people. However, as noted earlier, NPM thrives where accountability, transparency and performance are all present.

Middle and senior management cadres contribute to the survival and performance of the institution in terms of policymaking and implementation. Therefore, the quality and competence of staff employed to these cadres are of great importance. Recruitment into these cadres is by the Lagos State Civil Service Commission in conjunction with the Office of the Head of Service. In the beginning, appointments were based on established structure and vacancy rates, as related to the different levels of management. Neutrality and impartiality in recruitment, promotion, discipline and dismissal of the civil servants were hallmarks of the Commission. Recruitment was an open competition regardless of sex, religion or class. However, the neutrality and impartiality of the Commission diminished over time due to some major developments.

First, recruitment became political and partisan. The five ${ }^{83}$ political divisions of the state clamour for representation in government. This led to improper employments and the disregard of vacancy positions. Political criteria overshadowed technical knowledge or expertise in the recruitments. The Commissioners representing each of the state's five political divisions demonstrated loyalty to their constituency by ensuring the recruitment of indigenes. For example, from the inception of Lagos State, the government has been very liberal in terms of recruitment of staff, as virtually every state of the federation except seven is represented in its workforce. The number of Lagos State indigenes in the civil service is 6671 or $50.21 \%$, South Western States numbered $5459^{84}$ or $41.09 \%$, and others constitute 1102 or $8.30 \%$ (Lagos State Public service Manpower Statistics, 2002).

This may be connected with the policy of the founding fathers who made recruitment irrespective of tribe or ethnicity, and many staff where recruited or seconded from the Federal and Western Region Civil Service. Second, Lagos State is a cosmopolitan state that attracts many people from other states, many of who were schooled and later had gainful employment in the state. Third, six out of the twelve Governors of the state were non-indigenes, a factor that might have influenced the recruitment pattern of the state, and also affect the relationship between the political and administrative leadership ${ }^{85}$. Therefore, during the civilian regime, the political leaders who are usually Lagosians tried to rectify this imbalance in the representation of the indigenes in the workforce through recruitment. In the process, the Civil Service Commission loses its political neutrality and impartiality, as each Commissioner tried to project the interest of its political division, by having their representatives at policy-making levels.

DSI commented on this, "A number of non-career persons are recruited into the service mid-stream at the level of policy formulation, occupying positions meant for seasoned administrators. Civil service career requires lifelong training within a particular cultural environment that had been missed by these individuals. Having people in positions for which they were not trained result in deterioration in the quality of policy formulation and execution. I pray that the service will go back to its days of glory." Supporting this, DSII said, "On the political side, merits are now sacrificed for other mundane issues. Unscientific methods of putting incumbent in positions, is working against efficiency." Remarking on this matter DSI said, "In the past, the system in Lagos State was noted for its fairness in rewarding hard working staff. However, recent political considerations and other issues have totally destroyed the

\footnotetext{
${ }^{83}$ The five political divisions in Lagos State are Ikeja, Badagry, Ikorodu, Lagos and Epe.

${ }^{84}$ These are neighbouring states to Lagos State.

${ }^{85}$ For example, an indigenous administrative leader may feel marginalized under a political leader who is a nonindigene. Conversely, an administrative leader that is non-Lagosian may feel marginalized under a political leader that is an indigene.
} 
system. People with different background and culture enter the service at every level of the system. The senior staff cannot guide their politically connected subordinate."

In reaction RPSII said, "There are different cultures now in the service, people from the local government and private sector now come to "boss" those already in the service. Many do not care to study the organization. Emphasis is no longer on service, lobbying is now the in thing. Leaders do not know their responsibilities. Many do not know what to teach the junior ones." Appointments now are based on connections and influence rather than merit. Furthermore, subordinates with political connections sometimes have greater powers at organizational decision making than the superordinates. These undermine the technical competence and chain of command emphasized by Weber.

\section{Box 5.2: The 1999-2001 Recruitment exercise}

The recruitment exercise from 1999 to 2001 by the civilian government employed over 2000 people into the State Government. This government did this for several reasons. First, the state rate of unemployment has risen to the highest level in Nigeria. Lagos State, because of the large presence of commercial and financial institutions, witnessed the influx of people especially university and polytechnic graduates, school certificates leavers looking for work. Being a civilian dispensation, there was much pressure on the government to recruit. However, many criticized the recruitment exercise. Initially the government tried to reintroduce competitive examination and interviews by deciding that the West Africa Examination Board on behalf of the State Government should conduct an examination for the applicants. However, the deal fell through and the Lagos State Public Service Staff Development Centre was then mandated to conduct the examination. On the day of the examination, many people who did not register with the Civil Service Commission heard about the examination and disrupted the whole programme. The government also tried, without much success, to interview through the various Local Governments. The recruitment finally went back to the Civil Service Commission, but it was highly politicised. Many people were recruited into positions they were ill suited for. Some people from the private sector were employed into senior management positions, a situation that infuriated many of the higher civil servants.

Source: From the research interview of PSSI in 2003

The recruitment into the administrative cadre was initially a rigorous process that sought out the best and the brightest since administrators are regarded as future policy makers. In particular, top-level management is critical to the service as they should provide quality policy advice and are accountable for quality performance in the service. The officers must have passed an external examination conducted by the Administrative College of Nigeria (ASCON) and other recognizable management institutions before they could be designated administrative officers. Entry into this cadre was very competitive. Those who fail these examinations are regarded as executive officers, a much lower administrative status despite their university degrees. In the early years of the Lagos State Government, administrative officers were groomed for high performance in the civil service's higher levels. The same level of competence is required of other professional cadres such as the medical, teaching, technical and superintendent.

Aside from direct recruitment, other ways of appointing staff into positions are through transfer, conversion, and secondment. Staff prefer transfers to the administrative cadre as it is groomed for leadership positions for policy implementations and considered 'privileged'. However, with the massive retirements undertaken by the various governments, especially during GVC12 regime, experience and capacity were lost. Many vacant positions, particularly in the administrative cadre, had to be filled. Officers from other cadres were transferred and converted into the administrative cadre. Initially, regardless of their previous level, the officer was converted to the administrative cadre on grade level 08 , which is the bottom of the middle management level. The wisdom is that the officer can learn the rudiments of the trade through learning-by-doing. 
However, during the transfers exercise in 2000, the officers were reduced by one grade level. Officers on grade level 14 went to grade level 13, while those from the teaching cadre dropped two grades (i.e. GL12). However, this was not consistent as some teachers were only dropped one grade depending on whom they knew. The implication of this was that staff appointed into the managerial positions were not acquainted with the rules and regulations that guide the civil service. At times, the subordinates have more technical knowledge than the newly transferred or appointed senior officers. This type of relation sometimes results into insubordination on the part of the junior officer.

Table 5.5: Lagos State: Ratio of Actual Strength of Public service with Administrative Staff

\begin{tabular}{|c|c|c|c|}
\hline Year & Administrative staff & Total N. of staff & Ratio \\
\hline 1982 & 145 & 50,012 & $1: 345$ \\
\hline 2002 & 1197 & 51,221 & $1: 43$ \\
\hline
\end{tabular}

Source: Lagos State Government, Ministry of Establishments and Training (Management services Directorate), 2002, and composition of Lagos State Public service (1982) as adapted from Tables 4.3 and 4.5, on pages 100 and 102 respectively, in Lagos State: Governance, Society \& Economy (Olowu 1990).

In Table 5.5, the ratio of actual strength of the public service in relationship with the administrative staff in 1982 was 1:345, while in 2002 it was 1:43. From inception to the early 1990s, the rigorous entrance-process into the administrative cadre accounted for the low number of staff in this level. In view of this rigorous assessment, they used to be very competent. Although the ratio of 1:345 is abnormal, the performances of these officers were excellent, and they contributed significantly to the good performance of the public service during this period. Many of the recent recruitment and conversion and intercadre transfer into this administrative cadre did not go through these rigors accounting for the proliferation of this cadre. For example in the year 2000, the Civil Service Commission conducted 254 intercadre transfers, out of which 225 were staff transferred into the administrative cadre from the Ministry of Education. Chart 5.3 graphically depicted the transfers that were made from the teaching cadre into middle and senior administrative cadres.

Chart 5.3: Lagos State: Intercadre Transfer decided by the Civil Service Commission, 2000

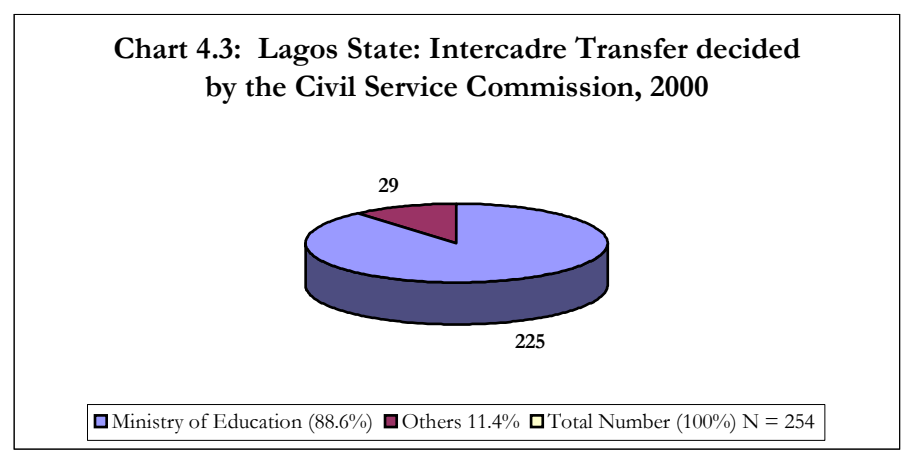

Source: Lagos State Civil Service Commission Annual Report for the year 2000.

\section{Promotions}

The Civil service used to have well established rules and regulations governing promotion. Deserving officers in the middle management level (Grade levels 08-12) were promoted every 
two years, senior management level (Grade levels 13-14) every three years, and the Directorate level between Grade level 15 to grade level 16 every four years. There is a tacit understanding amongst the staff that everything being equal in terms of job performance and discipline one will be promoted along with colleagues. The staff knew each other. Promotion is almost automatic and promotion interviews, mere formalities ${ }^{86}$. However, in 1974 the Report of the Nigerian Public Service Review Commission recommended the merit system whereby promotions were a combination of seniority and merit.

Therefore, seniority was no longer the only criterion for promotion. The introduction of merit had its own unintended consequences as it brought in some measure of short-term subjectivity especially on the parts of political leaders. Many gave accelerated promotion to those working for them under the guise of rewarding hard-working individuals who now attain positions superior to their former seniors. This in turn affected the morale of such officers and an avalanche of protests and petitions ensued. This trend led to officers lobbying for posts to politically "lucrative offices", a process regarded as cheap and easy way for accelerated promotions. According to DSI, "The system was encouraging the so-called high-flyers, but it was actually promoting preferential treatment." These politically motivated promotions and postings tend to be doing more harm than good to the government.

On the part of the administrative leadership, subjectivity had been introduced to the rating of officers through the open Annual Performance Evaluation Report (APER). A number of superordinates tend to overrate the performance of their subordinates in order not to appear too strict or be accused of barring them from being promoted ${ }^{87}$. It was observed that many staff were over-rated to the extent that appraisal forms had to be "moderated" before they could be considered and used. APER is meant to assess work schedules, training needs, ability to meet targets, and other staff-related matters. These other important aspects are usually not given adequate importance

Overall, some recruitments and promotions are based on patronage, not merit. This adversely affects the administration as inefficient and incompetent people are sometimes recruited and inept staff with political connection are rapidly promoted and upgraded. This usually affects the morale of hard working staff that feels intimidated and unable to do anything about the perceived injustice. Staff with knowledge and experience recoil into themselves, as they are usually not given the opportunity to give quality advice. In his opinion, GVM8 believes that "the civil service has been so much politicised". Supporting this observation, DSI reminiscences that the civil service he joined "had no discrimination in terms of promotion and welfare package. All tribes and religions were treated equally." All the informants interviewed for this study are all of one accord, that esprit de corps that was the hallmark of the old bureaucracy has been lost because of the lack of confidence in the civil service due to politicisation of the system.

Table 5.6: Lagos State: Factors Affecting the Quality of the Civil service, according to Interviewees.

\begin{tabular}{|l|c|c|c|c|}
\hline Univariate Analysis & & N & Mean & Sig \\
\hline $\begin{array}{l}\text { Recruitment and promotion no } \\
\text { longer based on merit }\end{array}$ & Yes & 103 & 4.078 & .001 \\
\hline & No & 35 & 3.371 & \\
\hline
\end{tabular}

Source: From the research survey in 2003

\footnotetext{
${ }^{86}$ The level of competence and performance of staff at the inception of Lagos State Civil Service makes nonpromotion to deserving officers an exception to the rules. But along the line subjectivity was introduced in terms of recruitment and promotion and the level of competence of staff were being queried. The same applied to the Federal Government Public Service.

${ }^{87}$ There have been cases where the superior officers would even give the performance appraisal form to the officers concerned to go and fill.
} 
When the respondents were asked to rate some of the human resource management policies they felt has adversely affected the Lagos State Civil Service, one of the factors that had a great level of significance is that recruitments and promotions are no longer based on merit. Table 5.6 shows the mean of the responses. The level of significance in the last column shows the difference between the mean of perception of those who agree ("Yes") and respondents who do not agree that the factors has an impact. The mean "Yes" score rated on a scale of 1.5 is 4.078, while "No" score has a mean of 3.371. The difference is significant at 0.001 level. However, due to the perceived incompetence of some staff, the government is trying to rejuvenate the system by bringing back merit through the reintroduction of examination organized by the Civil Service Commission and Lagos State Public Service Staff Development Center being the operational arm.

\section{Postings}

In the past, postings were done centrally according to profession. The Office of the Head of Service did the posting for the Administrative staff, Accountants by the Accountant-General office, and Auditors by the Auditor-General Office. Mass postings were affected every two years and the officers rotated around the Ministries. The wisdom was that each officer would have a working knowledge of the various Ministries. This helped the bureaucracy to develop the institutional capacity through training and experience. As soon as the posting is announced an officer was required to clear his table of pending work and hand over his schedule to his superior officer. The posting order was meant to be obeyed. However, much has changed. Officers with political "godfathers or connections" may refuse to obey the order and insist on retaining particular desired posts. Often another posting instruction would support them to remain at their posts. This situation creates undesirable "sacred cows", an action that incapacitates and infuriates Heads of Departments.

Although, the various professions are still under the "control" of their office, the Head of Service has the overall say. Depending on how politically inclined the Head of Service is, some of the postings now have political undertones. Staff lobby to be posted to Ministries of their choice. In view of the relatively low salaries, staff want to be posted to Ministries where they feel there would be financial gains such as Lands, Housing, Transportation, and Environment Ministries. Postings to offices within the Civil Service Commission, Establishments and Training Ministry, where emphases are on rules and regulations, with no perceived monetary rewards are seen as "punishments". Staff then depend on people with political influence to help effect their postings. These types of postings sometimes end up with "round pegs in square holes", and this ultimately affects the performance of the civil service. Remarking on this, DSI said, "Postings are now made that have no bearing on officers' skills and experience. People have now taken to making money."

The relatively low salaries and the high inflation that negatively affect the workers' salaries make staff jostle for posts. In Nigeria according to Salisu (2001), anecdotal evidence shows that the public servants are the least paid when compared to their private sector counterparts. Further, public service wages and salaries are not merely low, but have also been affected by wage erosion and in real terms there are shortfalls in the value of the salaries. For example, during 1980-1992 and 1970-1992, real wages declined on average by $14 \%$ and $34 \%$ respectively (Table 5.7). Although recently there have been attempts at salary review by the Federal Government to increase the national minimum wage per month from the equivalent of US\$ 1.20 to US\$ 41.77 in 1998 and US\$ 53.91 in 2000, by the regimes of General Abdul- 
salami Abubakar and President Olusegun Obasanjo, respectively ${ }^{88}$. Even though Lagos State was one of the state governments that was able to pay the minimum wage, the staff are still experiencing economic hardship because the state is also one of the most expensive to live in. Staff therefore seek for various means to augment their salaries ${ }^{89}$.

Table 5.7: Nigeria: Real Wages (Maximum, Minimum \& Annual Percentage change) and inflation rates (Period Average Percentage change) 1970-1997

\begin{tabular}{|l|c|c|c|c|}
\hline & $\mathbf{1 9 7 0 - 1 9 7 9}$ & $\mathbf{1 9 8 0 - 1 9 9 2}$ & $\mathbf{1 9 7 0 - 1 9 9 2}$ & $\mathbf{1 9 9 2 - 1 9 9 7}$ \\
\hline Real Wages & 5.25 & -14.12 & -34.17 & n.a \\
\hline Inflation & 14.36 & 19.79 & 17.29 & 36.22 \\
\hline Maximum & 29.17 & 44.00 & 43.15 & 72.81 \\
\hline Minimum & 3.40 & 5.56 & 3.40 & 7.36 \\
\hline
\end{tabular}

Source: Adapted from National Salaries, Income and Wages Commission of Nigeria, Revised and Harmonized Public service Salary Structure and allowances for the Federal Public Service, various years; Federal Office of Statistics of Nigeria, Annual Abstract of Statistics, various years. The trend in real wages was estimated by regressing the logarithm of real wages against a time trend over the different sub-periods. As presented by Salisu (2001) Table 3 , on p 6 .

Reacting, RPSI opined, "The hard work of the founding fathers and the calibre of staff at the inception of the state helped in the excellent start the state had. These ones spent all their lives to build the civil service and all the good work they spent their lives on are now being destroyed. There must be attitudinal change, and staff need to go back to the basics. We must put people who have integrity and experience in position of power. Have enough courage to dictate where the staff should go and serve. The individual staff too must address his mind to contribute his quota to the progress of the State. In all components of the public sector, there must be excellence in service, not what one can gain from it. All actors including political leaders must work. Everybody should be aware of what they can do for the service and the State. Leadership must be by examples. There must be integrity."

While commenting on this trend, PSSI remarked that, "at the beginning, discipline and the rules were applicable to everyone", when she joined the civil service. Another informant, PSSIII was of the opinion that the "ethics, ethos of discipline, loyalty, courage, tact and industry of the civil service are no longer adhered to." DSI opined, "Indiscipline and truancy are now common place." This type of system does not augur well for good performance in service delivery even within the government.

\section{Training}

Training and development are hallmarks of the merit system. At inception and in subsequent years, the Lagos State Government has spent much money on training. However, the training policy became uncoordinated. It was not specifically designed or targeted at creating a virile civil service, or enhancing the capacity and efficiency of staff. Many of the trainings were haphazard and irrelevant. Some of the external consultants used were not competent. Patronage was based on political affiliations. Monitoring and evaluation of training in line with the proposed objectives were never done. The government did not get value for money. Olowu

\footnotetext{
${ }^{88}$ Salisu (2001) cited other African countries that are experiencing similar trend of wage declining and wage erosion between the senior civil servants and the junior staff. He used the parallel market rate for the conversion of the 83.8 Naira to 1US\$ (1998) and 102.02 Naira to 1US\$ (2000).

${ }^{89}$ There is more information about the Nigerian federal pay system and its influence on the state level governments in the section on finance and economic policies.
} 
and Adamolekun, (1999) observed the same pattern in other African countries and summarized:

- Training is often treated as a discrete event, not part of an overall program of organizational improvement.

- Many trainees are selected on the basis of the bureaucratic politics and patronage rather than on the basis of the greatest need.

- Competent trainers are rare, as training is itself a poorly developed profession.

- Training curricula and models are usually based on borrowed models that are rarely updated.

- Classroom-based, academic-style teaching dominates most training programs, raising serious questions of relevance.

- Training evaluations are usually limited to assessing happiness levels rather than the impact on knowledge, attitudes, behaviours, and job performance.

- Most training institutions are poorly financed and managed and are usually heavily dependent on Government

Lepak and Snell (2002) in their examination of human resource architecture identify four types of employment: knowledge work, job-based employment, contract work, and alliance/partnerships. Staff in knowledge-based employment are essential to the organization. They use their heads to strategize for the survival and development of the organization. For the purpose of this study, we consider the knowledge-based employment in the Lagos State Civil Service as the officers in the managerial level, grade level 13 and above. In view of their roles in policy formulation and evaluation these officers should be exposed to qualitative training from the beginning of their career. It has been observed, however, that some of the officers in these cadres are ill equipped for the positions they occupy. Some of them are not even conversant with the civil service rules and financial regulations, which are supposed to be the civil servant's "bible". They are therefore incompetent at policy formulation and implementation.

Learning organizations help their members enhance their capacities through continual training, on-the-job skills development and education. In the new competitive environment, there are emphases on various types of knowledge. These have made human and social capitals to assume important roles in organizations (Schultz 1961). The impetus behind this is the organizations' needs to gain a competitive edge over rivals. The competitive edge of the civil service is the ability to maintain reforms that create an environment of creativity and innovation. Therefore, education and training are regarded as pivotal in the development of a knowledgeable and skilled labour force and growth of a quality service delivery. No wonder staff development and training was one of the most important aspects of the 1988 Civil Service Reforms. The government was enjoined to spend at least $10 \%$ of its recurrent expenditure on staff development and training. But successive governments in Lagos State have not been able to achieve this target.

One of the factors that is affecting the standard of training in the Lagos State Civil Service is that the training programme is not centrally coordinated. The Lagos State Public Service Staff Development Centre, which metamorphosed from Staff Development Centre, coordinates the training programmes of officers from Grade levels 1-12. The Ministry of Establishment and Training focuses on the senior and top management cadre, that is Grade levels 13 and above. This Ministry also handles overseas training, and long term training, like university degrees and polytechnics by which the attendees will be converted to a superior cadre after completion. The various Ministries also train their staff. These three arms of training outfits in the Lagos State Civil Service try to develop the institutional capacity of the Lagos State Civil Service. 
Table 5.8 shows the amount of money expended on training of staff (G.L 13-17) to total recurrent expenditure of government between 1988-2002. From 1988, the Table shows that the least number of staff trained within this period was in 1994 and 1995, with only 197 and 198 staff. This was the tenure of GVM10, and this period reflected the social upheaval that was going on in the country, as not much attention was given to training. However, GVC9, GVM11 and GVC12 must be commended for their efforts in staff training. Due to the fact that more money was injected into training (because of the increasing high cost of training), more staff were also exposed to training, even at international levels.

Table 5.8: Lagos State: Expenditures on Staff Training (G.L 13-17) as Share of Total Recurrent Expenditure of Government, 1988-2003 (in Naira and percentages)

\begin{tabular}{|c|c|c|c|c|c|}
\hline Governors & Year $^{90}$ & $\begin{array}{l}\text { N. of Senior } \\
\text { Management } \\
\text { level } \\
\text { (13-17) trained }\end{array}$ & $\begin{array}{l}\text { Amount ex- } \\
\text { pended in } \\
\text { Naira }^{91}\end{array}$ & $\begin{array}{l}\text { Total recurrent } \\
\text { expenditure of } \\
\text { Government } \\
\text { ( } \$ \text { Million) }\end{array}$ & $\begin{array}{l}\text { Percentage of the } \\
\text { amount expended } \\
\text { to the total recur- } \\
\text { rent expenditure } \\
(\%)\end{array}$ \\
\hline \multicolumn{6}{|l|}{ GVM8 } \\
\hline & 1988 & 211 & 200,000 & 492.17 & 0.04 \\
\hline & 1989 & 242 & 400,000 & 493.38 & 0.08 \\
\hline & 1990 & 242 & 400,000 & 825.53 & 0.05 \\
\hline & 1991 & 397 & $4,303,454$ & $1,009.19$ & 0.43 \\
\hline \multirow[t]{2}{*}{ GVC9 } & 1992 & 430 & $2,052,300$ & $1,962.97$ & 0.10 \\
\hline & 1993 & 463 & $2,450,250$ & $2,574.85$ & 0.10 \\
\hline \multicolumn{6}{|l|}{ GVM10 } \\
\hline & 1994 & 197 & $1,857,500$ & $2,929.21$ & 0.06 \\
\hline & 1995 & 198 & $2,051,500$ & $4,329.24$ & 0.05 \\
\hline & 1996 & 303 & $6,712,730$ & 5,322 & 0.13 \\
\hline \multicolumn{6}{|l|}{ GVM11 } \\
\hline & 1997 & 415 & $18,127,788$ & 7,714 & 0.23 \\
\hline & 1998 & 703 & $32,479,000$ & 10,343 & 0.31 \\
\hline \multicolumn{6}{|l|}{ GCV12 } \\
\hline & 1999 & 1079 & $36,925,121$ & 12,009 & 0.30 \\
\hline & 2000 & 1859 & $56,991,170$ & 19,868 & 0.29 \\
\hline & 2001 & 2659 & $82,441,574$ & 35,808 & 0.23 \\
\hline & 2002 & 975 & $33,715,420$ & 36,312 & 0.23 \\
\hline
\end{tabular}

Lagos State Ministry of Establishments, Pensions and Training, Training Department, 2003.

The Lagos State Public Service Staff Development Center was officially opened in 1995. Table 5.9 shows that the center offered only two courses for middle management and junior staff (G.L 01-12) that year. In subsequent years the number of staff trained and courses offered increased. The highest number of attendance recorded in 2000 and 2003 with 2367 and 2353, respectively.

\footnotetext{
${ }^{90}$ Please note that there are overlaps in the last year of the preceding Governor and the first year of the next one.

${ }^{91}$ The conversion to US\$ is in chapter one.
} 
Table 5.9: Lagos State: Percentage of Civil Service Staff (G.L 01-12) Trained and Number of Courses Attended, 1995-2003

\begin{tabular}{|l|c|c|}
\hline Year & $\begin{array}{c}\text { N. of Middle Management and } \\
\text { Junior staff level (01-12) trained }\end{array}$ & $\begin{array}{c}\text { N. of Courses } \\
\mathbf{9 2}\end{array}$ \\
\hline 1995 & 32 & 2 \\
\hline 1996 & 1038 & 56 \\
\hline 1997 & 2206 & 90 \\
\hline 1998 & 2250 & 96 \\
\hline 1999 & 2146 & 82 \\
\hline 2000 & 2367 & 73 \\
\hline 2001 & 1639 & 56 \\
\hline 2002 & 2353 & 75 \\
\hline 2003 & 2254 & 65 \\
\hline
\end{tabular}

Source: Data provided by Lagos State Public service Staff Development Center, Magodo ${ }^{93}$ (2003).

In spite of the money expended on training in the Lagos State Civil Service, the lack of coordination makes it difficult to know the exact courses some of the staff have been exposed to. This leads to some staff attending similar courses at both LSPSSDC and those organized by the Ministry of Establishments and Training. Also monitoring and evaluation of training programmes are not taken seriously, this coupled with lack of a comprehensive policy on staff development and training makes some of the respondents to doubt the relevance. While the research noted that many respondents say that the courses are relevant, they complained about the inability to use some of the insights gained in the courses they attended.

Table 5.10: How Relevant Are the Training Programmes?

\begin{tabular}{|c|c|c|c|c|}
\hline & & $\mathbf{N}$ & Mean & Sig \\
\hline \multirow{3}{*}{$\begin{array}{l}\text { Training and retraining not } \\
\text { mandatory or relevant }\end{array}$} & Yes & 101 & 3.465 & .014 \\
\hline & No & 36 & 2.944 & \\
\hline & & 137 & 3.328 & \\
\hline \multirow{3}{*}{$\begin{array}{l}\text { Where training is relevant, no } \\
\text { opportunity to utilize them }\end{array}$} & Yes & 104 & 3.798 & .105 \\
\hline & No & 35 & 3.486 & \\
\hline & Total & 139 & 3.719 & \\
\hline
\end{tabular}

Source: From the research survey in 2003

According to Table 5.10, the mean of those who responded, "training and retraining is not mandatory or relevant" is 3.465; and the Mean for those who believe that "where training is relevant, there is no opportunity to use them" is 3.798 . The indication here might be one of resignation rather than a negative judgement on the relevance of training by itself. In other words, there is some measure of correlation of these responses. One can summarize it this way: "yes, training is important but when I am trained, it is unlikely that I will have an opportunity to apply the knowledge gained". However, the level of significance for the factor "training and retraining not mandatory or relevant" is .014 or 5\% level of significance, which means the respondent actually believes that this factor affect the quality of service. On the

\footnotetext{
${ }^{92}$ Amounted expended depends on fees charged. Different fees were charged ranging from 15,000-30,000 Naira per participant.

${ }^{93}$ The Lagos State Public Service Staff Development Center was opened in 1995.
} 
other hand, for the factor "training is relevant, but no opportunity to use them", the statistical level of significance is .105. In other words, more people believe that training by itself is useful but the training in Lagos State Civil Service has not been relevant.

According to RPSIII, "Although some officers have been exposed to modern management courses, which are a lot of fulfilment on the part of the attendees. But most of the new knowledge learnt could not be applied because it is new to majority of the staff, even the boss may not understand what it was all about. Automatically, he will frustrate the implementation of the new techniques. Therefore, in spite of the money spent, the system may not achieve what it wanted to do with the new knowledge acquired by the officer. In most overseas training what is learnt could not be applied. There is need to overhaul the staff development programme, and ensure that more people are trained. It is only then that the overall effect will be felt".

In his contribution, DSI said, "Although more people with academic qualification are being recruited, one cannot separate training and career development. Presently, training is not well-structured in terms of career progression of staff. There was a law made at one time that about $10 \%$ of the current expenditure of government should be on training, but no government has ever been faithful to this. Also the attitude of members of staff to training is negative, but there are some exceptions. The in-service training introduced by the state government is considered good, as some members of staff have used this to advance their knowledge and education. However, there is room for improvement. I belong to the old breed and I used training to develop my own skills. Not just taking the allowances but also acquiring the knowledge. The attachment I had overseas was an experience that I will cherish. I received training right from junior officer to top management cadre. I repeat, it is not possible to separate training and career development." However, GVM8 said,

"There is a need for the government to emphasize training and retraining of staff. There should be continuous training of the staff."

In times past, the Lagos has used training and retraining of its staff as an effective tool in developing a dynamic and vibrant workforce.

Still commenting along this line, PSSII said, "Training on the job is very important. There must be a training profile for an officer on grade level 08 . He must have a training programme laid out for him from his point of entry. A specialized training to prepare him for GL10 must be mandatory and this must cut across board. The training would give the professionals the opportunity to have a broad idea of what is important, and the administrative officers on becoming a generalist. There is a need to refocus and bring up the quality of the staff to be commensurate to the private sector. Without training the system will breed mediocres." 
Box 5.3: PSSI thoughts on Training

Education is the acquisition of knowledge, and training is the application of knowledge. We are empowered when we become knowledgeable. If all cadres of staff are exposed to training, jobs will be more enriched and the quality of service higher. The sacrifices are that the government should be able to spend more money and the superordinates to encourage those under them to attend training courses. In the area of skill acquisition, the results have been visible i.e. a clerical staff can become a typist or a Local Government Administrator. However, there is a need to carry out interviews of both superiors and subordinates in order to assess the impact of the training on the participants. The Planning and Research Departments should draw up questionnaires and interview staff on the impact of training on their jobs. The Department Training Officers should develop training needs for officers so that people would not be sent to irrelevant training. The training in the entire civil service is not yet unified. Trainings of officers on GL 13 and above are presently being given out to consultants. One needs to take this issue from scratch. The government is spending millions of Naira, but one needs to ask whether the training is getting to the trainees, and is the quality of service improving? For example at the Center the development of programmes for officers on GL1-12 are needs based and we make sure that learning is taking place. We have meetings with Director (Finance and Administration) and Departmental Training Officers and discussed how to identify training needs. Officers should not be put on generalized training programmes like leadership, management and administration all the time. At this level the training should be needs-based. Programmes should not be run blindly. Also, programmes have a life cycle; for example, make sure that everybody comes in for induction courses. All other performance improvement courses must be as a result of needs. Retraining is essential for those who have been redeployed or have their schedule expanded. There is a need to carry out research in order to determine training needs, and how many people in the cadre are needed to be trained. For training to be effective, there is need to expand the number of people that facilitate. By this you avoid repetitions and there must be room for criticism. Trainees must learn to do impromptu test. There must be continuous evaluations. A leader is not expected to know everything, or have skills in all the areas. But he/she must have basic knowledge and training in management. The Lagos State Public Service Staff Development Center is a training institution, and should be able to teach GL12 and above on the rudiments of management, motivation and leadership. After each training there must be guidelines on report writing and evaluation to know that learning took place.

Source: From the researcher's interview with the informant in 2003.

In her comments, RPSI remarked, "My personal experience with training is helping in my post-retirement life. As a consultant, I am able to share my experiences. Training has exposed me to view the system and life differently. Presently, I give induction courses to staff, and I encourage them to seize every opportunity they have to attend training because it helps in their own self-development. I thank the Lagos State Government for exposing me to different kinds of trainings both internally and externally. We need to train people beyond their cadres. It is good for both the state and the individuals. Some people have the opportunity of being exposed to annual conferences. It makes for a sense a belonging. The state must require that meaningful programmes be produced for the staff. Some of the training are relevant for example, personnel in the medical field need to go for specialized training. However, some trainings are for self-aggrandizement and irrelevant. Some people are only interested in the allowances. We used to insist on $70 \%$ participation before they are qualified for certificate."

According to RPSII, "Government has always shown interest in training. People are given study-leave in order to encourage them to be educated. Training helps them to be better workers. Civil servants are trained both in and outside the country. All the trainings I have been exposed to were relevant to my schedule of duties. There is a need for firm control over training so that the selection will be based on facts not sentiments". In practical application, many people have not been able to utilize the training they had. Training has to be systematic, consistent, continuous, and relevant. There must be training for progression between grades, and orientation to the new ministries postings. Commenting on this, RSSG said, "Some trainings have been without purpose. They are not structured or linked to any particular objectives that will add value to the quality of service. Even there has not been constant evaluation of most of these trainings and their relevance to the system." 


\section{Retrenchment}

Another important aspect of the human resources management in the public service is the method by which staff are made to disengage from the service. The public service used to have security of tenure or renewable contract; it was a career without arbitrary termination of appointment. The rationale behind Merit system, according to Olowu and Adamolekun, (1999), is that there will be, "continuity and predictability of government business, fairness and impartiality to citizens, loyalty to incumbent political leadership, and smooth leadership succession." All these changed over time. Arbitrary termination of appointment became the order of the day, and it is believed that this contributed to the poor performance or unprofessional conducts of some civil servants.

The retrenchment exercises or huge layoffs were started in 1975 by the Federal Government and subsequently imitated by some state governments. These left major adverse effects on the civil service such as disruption in the career pattern of civil servants. There was no longer security of tenure. The retrenchment exercise, albeit initially minimal in Lagos State, affected the morale of the staff. This also led to the loss of essential capacity and experience, which was aggravated by the freeze on recruitment. This retrenchment was targeted at senior and top management, many of whom are just getting to the peak of their career. The loss of skills was irreparable while meritocracy was discarded for cronyism.

Furthermore, during the regime of GVC12 from 1999 many experienced hands were also laid off. This untimely retirement of Lagos State civil servants affected the effectiveness and morale of the staff for the following reasons:

- Loss of confidence in the system;

- Fear of early retirement led to illegal acquisition of government properties; bribery and corruption;

- Involvement in partisan politics;

- Disruption in the career pattern of civil servants, and

- Loss of essential capacity.

The Lagos State Civil Service Commission is responsible for the appointment, promotions, discipline, transfers, and disengagement of staff from the service, and so on from grade levels 07-16. Exit from service can be in terms of withdrawal of service, compulsory or voluntary retirement, termination of appointment, dismissal, resignation, and death. Table 5.11 shows the numbers of staff affected as recorded in the Annual Reports of the Lagos State Civil Service Commission between 1985-2000. 
Table 5.11: Lagos State: Numbers of Exits from the Civil Service, 1985-2000

\begin{tabular}{|c|c|c|}
\hline Governors & Years $^{94}$ & Exit from Service (N.) \\
\hline GVM6 & $\begin{array}{l}1985 \\
1986\end{array}$ & $\begin{array}{l}111 \\
110\end{array}$ \\
\hline GVM7 & $\begin{array}{l}1987 \\
1988\end{array}$ & $\begin{array}{l}60 \\
36\end{array}$ \\
\hline GVM8 & $\begin{array}{l}1989 \\
1990 \\
1991\end{array}$ & $\begin{array}{c}223 \\
33 \\
33\end{array}$ \\
\hline GVC9 & $\begin{array}{l}1992 \\
1993\end{array}$ & $\begin{array}{l}11 \\
22\end{array}$ \\
\hline GVM10 & $\begin{array}{l}1994 \\
1995 \\
1996\end{array}$ & $\begin{array}{c}14 \\
13 \\
8\end{array}$ \\
\hline GVM11 & $\begin{array}{l}1997 \\
1998\end{array}$ & $\begin{array}{l}61 \\
16\end{array}$ \\
\hline GVC12 & $\begin{array}{l}1999 \\
2000\end{array}$ & $\begin{array}{l}30 \\
17\end{array}$ \\
\hline Total & & 798 \\
\hline
\end{tabular}

Source: Lagos State Civil service Commission Annual Reports between 1985-2000.

Although the reports of the Civil Service Commission recorded that the number of people that exited from the Lagos State Civil Service between 1999 and 2000 were 30 and 17 staff respectively, in actual fact, the numbers were higher. During this period of GVC12 a lot of restructuring took place, in terms of retrenchment, but the Civil Service Commission could not record it because the Commission was not involved. The retrenchment was done under a strict code of secrecy. The Office of the Head of Service did the exercise, with the involvement of the various Permanent Secretaries and Heads of Governmental Departments. About 4,447 staff were affected, and the reasons given for the retrenchment ranged from length of service, low qualifications, old age, insubordination, redundancy, ill health, low productivity, contract appointment expiration, voluntary retirement, fraud, illegal granting of approval, compromise, incompetence, indolence, lack of leadership, doubtful loyalty, unrequired service, misconduct, mental problem/insanity, absenteeism, state security, and so on. Most of the offices in the Lagos State Public Service were affected. The distribution per Ministry was as follows:

1. Ministry of Environment \& Physical Planning 329

2. Ministry of works $\quad 512$

3. Ministry of Agriculture \& Cooperatives 311

4. Office of the Chief of Staff 28

5. Public service office 22

6. Ministry of home Affairs \& Tourism $\quad 62$

7. Cabinet office 12

\footnotetext{
${ }^{94}$ Please note that there are overlaps in the last year of the preceding Governor and the first year of the next one.

${ }^{95}$ The researcher could not authenticate this number and the breakdown because the restructuring exercise has not yet been put in any official Government's report or gazette.
} 
8. Ministry of Health 288

9. Office of the Auditor General for Local Govt 30

10. Hospitals Management Board 1082

11. State primary education Board 6

12. Post Primary Teaching Service Commission 457

13. Agric development Authority 4

14. Ministry of Youths, Sports \& Social Develop 104

15. Ministry of Establishments, Training \& Job Creation 22

16. Parastatals Monitoring Office 12

17. Ministry of Rural Development 6

18. Ministry of Information \& Strategy 14

19. Board of Internal Revenue 131

20. Electricity Board 10

21. Ministry of Transportation 124

22. Ministry of commerce \& Industry 42

23. Ministry of finance 21

24. Ministry of Housing 29

25. Lagos Horizon Publishing Company 27

26. The State Treasury office 122

27. Ministry of education 175

28. Lagos State Polytechnic 145

29. Office of the State Auditor General 6

30. College of Primary Education $\quad 14$

31. Adeniran Ogunsanya College of education 105

32. Office of Local Government Administration 73

33. Ministry of Economic Planning \& budget 20

34. Public Works Bureau 62

35. Ministry of Special Duties \& Inter-Governmental Relations 5

36. House of Assembly 7

37. Ministry of Women Affairs \& Poverty Alleviation 28

TOTAL $\quad 4447$

It is quite difficult to differentiate the grade levels into senior and junior but it could be deduced that the ratio of retirement is in the range of senior - $35 \%$ and junior - $65 \%$. The reason being that many junior staff had stagnated at the peak of their career progression on grade level 07 , as many of them did not have additional qualification to exceed that grade level. 


\section{Exit from the Lagos state civil service by regimes between 1985-2000}

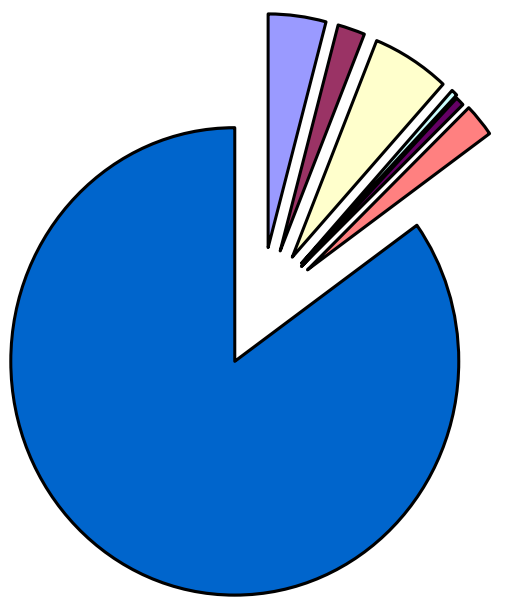

口GVM6

$\square$ GVM7

$\square$ GVM8

$\square$ GVC9

口GVM10

$\square$ GVM11

$\square$ GVC12

Source: Lagos State Civil service Commission Annual Reports between 1985-2000 and Office of the Head of Service on the number of staff that left the services of the Lagos State Government.

This was a giant stride taken by GVM12, because workers in Lagos State have always resisted the issue of restructuring. But this one took the majority of the staff by surprise. There came a lot of protests and the government set up a Committee to look into the various petitions, but very few staff were reinstated ${ }^{96}$. Both the respondents and the informants believed that the retrenchment exercise led to considerable loss of confidence in the system because as the retrenchment was going on, the government was at the same time hiring new people. In 1999, 250 people were employed and 2371 in 2000 . The essence of right-sizing an organization is to retrench unneeded staff and employ the ones it really needs. However, as discussed earlier there were many improper hiring during this period. Many people did not see the sincerity of the government in wanting to right-size the government, but they see it as an attempt to put their own people into government.

Both the respondents and the informants believed that the retrenchment exercise affected the quality of service rendered by the civil servants. According to PSSI, "Some of the negative policies are the mass retrenchments. This sent the wrong signals to those who were not affected and those who wanted to join the civil service. The exercise should have been done with some discretion. The government should have retrenched the 'dead woods' that is, the unproductive staff and let the rest retire voluntarily. There should be a policy whereby after eight years, one can go for reskilling or retooling and learn something for one's retirement. The trainee could pay half and the government the remaining half of the course fees. This

\footnotetext{
${ }^{96}$ The researcher could not get the actual number of staff reinstated because of the secrecy involved.
} 
way, voluntary retirement will be orderly and planned. Retrenchment should not become a policy."

According to DSI, "The retirement exercise was necessary but was ill-timed and not properly executed. There was no fairness, no justice; nobody thought about the career of the staff." Commenting on the issue, RPSII opined, "The retrenchment eroded the confidence of the staff in the system. The necessary rules and regulations for retirement were not followed. People just find letters of retirement on their tables. This really affected performance, because staff started being afraid to disagree with their bosses, in order to keep their jobs." Also, the fear of retrenchment made a lot of the staff especially those at the top to become extremely cautious. In her contribution, RPSIII remarked, "This brought about a decline. Nobody was monitoring what was happening in the service again. Gratification and corruption became rampant. Staff were no longer accountable."

Reminiscing, GVM1 believed that

"A lot of harm was done during the purge of 1975 by Muritala regime. It really destroyed the system. Before, there was tenure of office and no need for godfatherism. The purge led to the confidence of the civil servants being shaken. And people started enriching their own pockets."

More than half of the respondents believed that fear of early retirement made many people to start to line their pockets. According to DSI, "civil servants used to enjoy security of tenure but this has been thrown over board, and has eroded the productivity instinct of the work force. Since the staff are not sure of the future, rather than serve they preferred to serve themselves. Before in Lagos State, nobody could belie the issue of free mobility of labour. But it was selective and scientific. However, recent political considerations and other issues have totally destroyed the system. A conscientious worker can not hope to be a Permanent Secretary again if he or she does not have a political backing." Many of the respondents believe that the career pattern of the staff was adversely affected during this period. Many officers had their career terminated when they were just about to reach the peak of their career.

In her own contribution, RPSII opines "On the negative side, early retirement of staff for no adequate reason is bad. Premature retirement leads to depletion of experience. The recent retirement exercise was more attitudinal than policies. It is the leadership that determines the culture of the system. In the past the civil service was a safe and unique place to work." Adding to the discussion, RPSIII remarked, "When the mass retirement started in 1975, many heard about their loss of jobs over the radio. That incident introduced insecurity into the service. Thereafter, many inexperienced staff were promoted to top positions in the service. This created morale problems and commitment went, especially for those who were by-passed." 
Table 5.12: Lagos State: Areas affected by Staff Retrenchment.

\begin{tabular}{|l|l|l|l|l|}
\hline & & N & Mean & Sig. \\
\hline Disruption in the career pattern of civil servant & Yes & 104 & 3.567 & .060 \\
\hline & No & 36 & 3.139 & \\
\hline Loss of confidence in the system & Total & 140 & 3.457 & .000 \\
\hline & Yes & 105 & 4.086 & 3.306 \\
\hline Fear of early retirement led to illegal acquisition of & No & 36 & 3.887 & \\
\hline Government properties & Total & 141 & .020 \\
\hline
\end{tabular}

Source: From the research survey in 2003.

Table 5.12 reports what the respondents felt about the retrenchment exercises. Loss of confidence in the system has the greatest level of significance. The mean "Yes" score rated on a scale of 1-5 is 4.086, where "No" has a mean of 3.306. The difference is highly significant. This shows that the respondents feel strongly about the loss of confidence in the system as one of the greatest factors that has adversely affected the institutional capacity of the Lagos State Civil Service. However, involvement in partisan politics shows a mean "Yes" of 3.600 and a "No" mean of 3.545, but the level of significance is low. This is contrary to the observation of the researcher and comments of all the informants, therefore one of the reasons one can give to this is that this factor has been subsumed under other factors like loss of confidence in the system.

Commenting on this, RSSG remarked, "There is need for the government to critically build and sustain the essential institutions and develop an effective public policy that will take care of the general good of the staff. The assets of most corporations are the human resources, invest in it and you will always reap the dividend. Build up the competence of the staff and the reward will be great, because they are capable to plough back into the system".

\subsection{Finance and Economic Policies}

Aside from the human resource management policies that affected the institutional capacities and public service performance, other aspects examined in this study are the finance and the economic policies. Table 5.13 reports the results when respondents were asked about the effect of the Structural Adjustment Programme (SAP) on government performance.

At the level of the bureaucracy, the Nigerian Government by 1986 was seen as being "big" and therefore "wasteful and inefficient in economic management" (Essien, 1990). The Federal Government was advised to scale down its role in economic activities and to downsize the public service to make it more affordable. It was hoped that this would reduce government's recurrent expenditures and the "cutback strategy" would result in a leaner government more focused on "core activities". Retrenchment or downsizing was due to the belief that the expenditure of the public sector in many Less Developed Countries (LDCs) was too great in relation to their revenues and resource base. By this "cutback strategy" the money 
saved would be used to augment the wage bill and pay civil servants decent salaries. However, the World Bank Report (1997) observes that the cuts did not result in higher salaries for those that remain.

First, the resulting cut in government spending, a phenomenon called "austerity measures" that was introduced by the Federal Government and the Structural Adjustment Programme (SAP) had two implications. This negatively affected the rate and amount of grants given to the state governments by the Federal Government. Ultimately, because many of the state governments relied on these subventions for the execution of the public services deliveries, these cuts adversely influenced their constitutional responsibilities.

Second, the Federal Government's economic policies also affected state governments' expenditures. Recurrent and capital budgets were significantly affected, causing a rise in the abandonment of capital projects. The civil service was not spared. The dismal economic performance had adverse effect on the salaries and remunerations of staff. Long periods of wage freeze resulted in reduced spending power of workers. This was further compounded by "wage erosion and compression" of the remuneration of senior civil servants in Nigeria (Olowu and Adamolekun, 1999). Inflation adversely affected living wages. Salary reviews to examine the consequences of continual fall in real wages were rarely carried out. Even when they were done, the salaries of the least paid are better reviewed (in terms of amount of remuneration) than the highest paid due to the populist rather than rational considerations, leading to severe wage compression.

Third, the retrenchments that were carried out marked another phase in the evolution of the public service in Nigeria. Although, this started with the military at the Federal Government level from the mid-1970s, a misguided exercise that destroyed experience and capacity in the public service. The loss of skills was irreparable while meritocracy was discarded for cronyism. The military sometimes paid scant regards for civil service rules and regulations as it stressed command and control, and the civilian later inherited this attitude. This period witnessed the introduction of "purges" or massive retrenchment of the Nigerian Public Service. The policies significantly affected the institutional capacity of the public service (Adebayo 2001).

Table 5.13: Rating of the Federal Government's macroeconomic policy of Structural Adjustment Programme.

\begin{tabular}{|l|l|l|l|l|}
\hline $\begin{array}{l}\text { Downsizing the Government through early retirement and } \\
\text { retrenchment. }\end{array}$ & Yes & Mean & Sig. \\
\hline & No & 35 & 3.314 \\
\hline Wage erosion & Total & 133 & 3.774 \\
\hline & Yes & 99 & 4.192 & .005 \\
\hline Wage compression & No & 34 & 3.559 & \\
\hline & Total & 133 & 4.030 & \\
\hline & Yes & 99 & 3.626 \\
\hline Inflation through devaluation of the Naira & No & 34 & 3.382 \\
\hline & Total & 133 & 3.564 \\
\hline
\end{tabular}

Source: From the research survey in 2003 
Table 5.13, shows that the two most important factors of the Federal Government's macroeconomic policy that affected the civil servants were downsizing the government through early retirement and retrenchment (.005), and wage erosion (.005). The fall in the value of the Naira had the following consequences on the public servants; (a) galloping inflation adversely affected the salaries and remunerations of staff; (b) decline in the purchasing power of workers; (c) wage freeze resulted in reduced spending power of workers. Nigerian Government workers were further exposed to "wage erosion and compression" at the infrequent salary reviews Olowu and Adamolekun (1999). The salaries of staff could no longer sustain them and their families. Absenteeism and late-coming to work rose, as staff started engaging themselves in other economic activities in other to maintain themselves. Both junior and senior staff engaged in moonlighting. The mean value for wage compression and inflation through devaluation of the Naira were 3.626 and 4.289, respectively. These are quite high, but these two factors appear insignificant in Table 5.13. One way to discuss this issue is that the importance of these variables are subsumed under the influence of wage erosion, which is quite high. Inflation and devaluation of the currency affected the salaries of Lagos State workers and their counterparts in other major urban areas.

According to the Central Bank of Nigeria (MEF \& BI 2004), in its reports on major economic, financial and banking indicators for Nigeria between 1980-2003, it shows that inflation was at its highest in Nigeria between 1993 and 1995. This was a period of political unrest and great economic crisis. Nigeria's inflation rate in 1993 was $57.20 \%, 57.00 \%$ in 1994 and $72.80 \%$ in 1995 . The urban areas were heavily affected, with domestic prices ${ }^{97}$ of $50 \%$, $61 \%$ and $59 \%$ in those three years. Since salary reviews were not in consonance with inflation, the salaries of workers became inadequate. Governments, both at the federal and state levels, have continuously witnessed demonstrations for salary reviews by civil servants because inflation had adversely affected the salaries of workers.

Nigeria has a long history of collective bargaining and negotiation for minimum wage. According to the National Minimum Wage (Amendment) Act of 2000, no employer should pay less that the minimum salary of 5,500Naira ${ }^{98}$ per month beginning May 2000. Many state governments were not able to pay this, which led to renegotiations between workers and their state governments. Lagos State was among the few state governments that could pay this salary, however it was at the expense of other government responsibilities. Since staff wages have eroded, incentives in terms of non-taxable, non-wage benefits such as housing allowance, fuel allowance, subsidized food, and free transportation had to increase.

In her comments, PSSI said, "On the financial side, the salaries are nothing to write home about. Although the salaries of the public servants have been reviewed upward, there are dis-savings. With zero saving, people now borrow knowing they cannot repay. Indiscipline amongst staff leads to people stealing and misappropriating government's funds. Due to wage compression, some of the junior staff earn more than their bosses and this makes control and discipline of staff very difficult. Some bosses cannot meet their financial responsibilities."

According to the National Population Commission (2005), Lagos State is the most urbanised city in Nigeria with 94 percent of its populace living in the urban area of the state. It is also recorded that with this level of urban dwellers, Lagos State surpasses the national average. The state was therefore one of the most negatively affected in terms of the high inflationary trend. The Central Bank of Nigeria (MEF \& BI 2004) records that by 1999 when the Fourth Republic started inflation rate came to $6.6 \%$ and the urban domestic prices were $8 \%$. However, by 2003 the inflation rate had risen to $14 \%$, while the domestic prices has gone up to $16.52 \%$.

\footnotetext{
${ }^{97}$ Change in domestic prices over time is indicative of the inflationary trend in a country.

${ }^{98}$ In 2000 the conversion rate was 1US\$: 999.50 . This makes the minimum wage to be approximately about $\$ 55$ per month.
} 
In explaining the above trend, two sets of explanations may be offered. The first may be connected to the policies of salary review of public servants by the Federal Government. In order to improve the productivity of workers, the Federal Government effected an upward review of the minimum wage from the equivalent of US\$ 1.20 to US\$ 41.77 in 1998 and US\$ 53.91 in 2000 respectively. The second inflation-inducing factor relates to the removal of petroleum subsidy, which led to rise in the price of petroleum products. Rises in energy costs always have a major and direct impact on food production and distribution of other services due to the rise in the cost of transportation.

In other to palliate the inflation situation for its workers, the Lagos State Government was one of the states that implemented the minimum wage, and also tried to provide a nontaxable welfare package. According to PSSIV, "Some of the government policies that affected the civil service positively are the welfare packages. The continual provision of staff quarters assist average public officer and motivate such staff to stay on to the job. If one compares the economic value of renting such from private investors it is astronomical. It also assists them to bridge the gap in their salaries with that of their counterpart in the private sectors. Also the government continues to allocate land to public servants with $40 \%$ rebate. While the private sector give Christmas bonus, the state government started to give about $10 \%$ of basic salary at the end of the year to staff as bonus. For the junior staff there are staff buses they ride free of charge. The government fuels the buses and provides a subsidized canteen that cushions the effect of the economy."

PSSIII contributed: "The improvements in the welfare packages have endeared GVC12 more to the civil servants. There are free bus services, subsidized meals, defraying some of burial expenses of staff are also some of the packages GVC12 has continued with. His government is currently working out the modalities for life insurance policy for every civil servant. (To) those that are already dead, benefits are given to their beneficiaries. The government also continues with the credit scheme facilities for those who are interested in buying or building houses. Furthermore, Permanent Secretaries are now given 2million Naira and their official vehicle on retirement. This policy is having a positive impact in the service, as they are careful with their vehicles. Government expenses on these cars are now reduced. All these are incentives that should make the staff to give back to the system".

There was also a high level of unemployment, and many private and commercial companies laid-off staff or even closed down. Many of these people now seek employment with the government; jobs they believe have more "security". The sentiment is that half-a-loaf is better than nothing. Not that the salaries can compare to earlier, but Lagos State is still relatively better in terms of regularity in payment of salaries. In spite of this, many of the Governors believed that the salaries should still be improved. According to GVM8,

"The salary should be looked into and be commensurate with the standard of living". Commenting, GVC9,

"If the civil servants are not adequately remunerated it will breed corruption. A hungry man will go to any length to make extra money."

The Central Bank of Nigeria (MEF \& BI 2004) recorded that in 1985-1987 the highest rate of unemployment was in the urban areas, with almost $10 \%$ of the population unemployed. The percentage drops to $3.90 \%$ by 1995 . However, by the year 2000 , unemployment has risen up to a record high of $7.20 \%$ in the urban areas. Lagos State being the most urbanized state was under the highest pressure. Being a civilian dispensation ${ }^{99}$, there was demand on the government to recruit. This is not without major implications. The main problem that confronted Governor GVC12 was how to effectively mobilize the internal and external resources in pub-

\footnotetext{
99 The civilian regime always recruits more than during the military regime because recruitment is a way whereby the indigenes can have more representation in Government.
} 
lic service deliveries and at the same time meet up with government's recurrent expenditure. In monetary terms, the non-wage bill and incentive package of the staff adds to the recurrent expenditure of the state government. Reacting to this, GVC12 stated, "The resources of the state are for all and not only for the civil servants". These cost increases, combined with Lagos State's rapid urban growth, stretch the provision of public services to the limits. The state continues to experience unreliable infrastructure facilities, and slum growth. Contending financial demands from salaries and remunerations affects the provision of public service.

Chart 5.5: Lagos State Government: Percentage of Administration Cost to Total Expenditure of Government, 1985-2003.

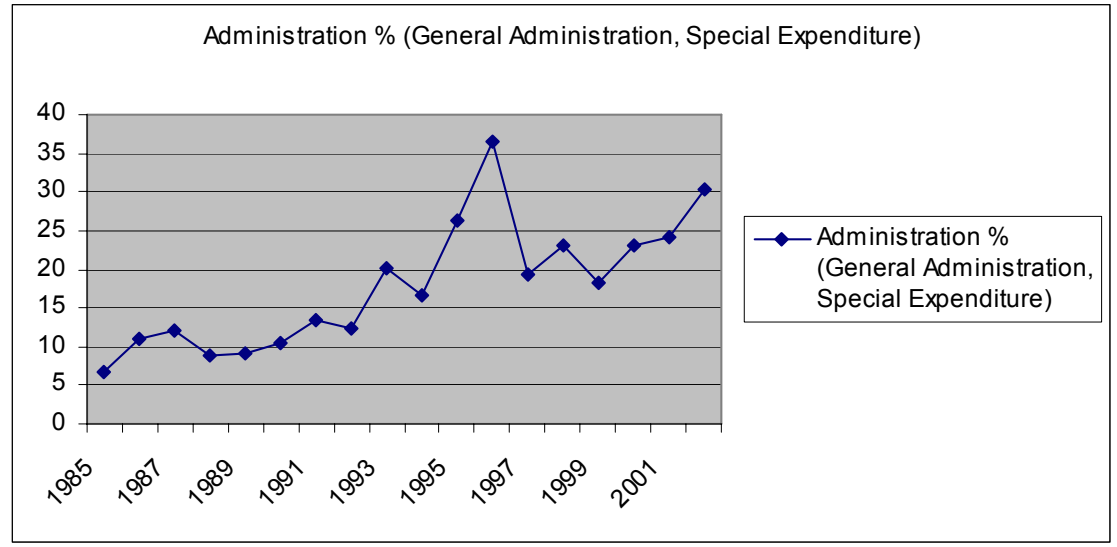

Source: Lagos State Government, Office of the Accountant General: Report of Expenditure between 1985-2001

Chart 5.5 shows the astronomical rise in the costs of general administration ${ }^{100}$. In the Lagos State sectoral allocation, administration rose from the record low of $6.6 \%$ in 1985 to its peak in 1996 at $36.48 \%$. General administration sector comprises of general administration and special expenditure. The use of the special expenditure is at the discretion of the Governor. The sudden jump in this sectoral allocation may be connected with Governor GVM11's anticrime push in the form of Operation Sweep. The Government spent a lot of money to sustain this unit in terms equipments purchases including cars, walkie-talkies, bullet-proof vests, and 2 helicopters. This period also witnessed demonstrations by the staff for salary increases. By 1997 , this sectoral appropriation reduced to $19.20 \%$ because the Governor had shifted his focus to roads and public transportation, which by then needed attention direly.

By 2002, under GVC12, this sector allocation reached $30.45 \%$. The sub-sector breakdown of the sectoral allocation shows that the appropriation to general administration always comes 4th - at $10.04 \%$ and $11.21 \%$ in 2001 and 2002, and $3.2 \%$ and $4.1 \%$ in 1985 and 1986 . This shows that the government is spending more on personal emolument, non-wage bills and allowances of staff. No wonder GVC12 complained that the staff should realize that he has other high cost public service demands to address and cannot afford to give all available resources to the staff.

Aside from this, almost all the governments in Lagos State have been deeply caught up in public service deliveries to the detriment of feasible economic projects and all these have put a lot of pressure on government finance. A major state resource area is taxation, but the state is having problems with revenue collection and there is no appropriate taxation strategy

\footnotetext{
${ }^{100}$ General administration is generally spent on recurrent expenditure like personal emoluments, non-wage bills, incentives and allowances.
} 
for companies and wealthy citizens. This problem traces back to the lack of institutional capacity to develop an appropriate taxation structure. Further, the Lagos State Board of Internal Revenue suffers from the problem of corruption including connivance where members of the public and companies bribe staff to receive reduced tax rates. Individuals and companies thereby appropriate the money meant for government treasury. This has a ripple effect, as the citizenry believes that the government is not providing appropriate public service, they in turn refuse to pay their taxes. So the vicious circle continues whereby the citizenry refuses to pay their taxes and the government has insufficient resources to provide these services.

In view of the weak institutional capacity and the corruption that pervades that Board of Internal Revenue during tax collection, the governments of GVM11 and GVC12 employed private consultants to collect revenues. These Governors believe that they can achieve more effective revenue collection through the NPM philosophy of contractualised management of public service deliveries. They argue that corruption and rent-seeking in the public sector make privatisation the most effective way to serve the public. NPM is successful where there is an effective institutional capacity to initiate and regulate privatised service delivery. Secondly, the public must demand transparency and accountability. Although the first civilian Governor of Lagos State, GVC5, did not contract out revenue collection during his regime from 1979 to 1983 , he was able to use the institutional capacity at his disposal to collect revenues for the state effectively.

Table 5.14: Lagos State Government Statement of Recurrent Revenue as at $31^{\text {st }}$ December 2000 in Naira

\begin{tabular}{|l|c|c|c|c|}
\hline \multirow{2}{*}{ Description } & \multicolumn{2}{|c|}{$\mathbf{3 1}^{\text {st }}$ December 1999 } & \multicolumn{2}{|c|}{$\mathbf{3 1}^{\text {st }}$ December 2000 } \\
\cline { 2 - 5 } & Estimates & Actual & Estimates & Actual \\
\hline Taxes & $8,391,438,850$ & $10,715,004,635.10$ & $13,065,000,000$ & $8,426,570,662.51$ \\
\hline Fines and Fees & $1,000,000,000$ & $2,988,331,219.27$ & $2,763,731,000$ & $1,284,120,717.25$ \\
\hline Licenses & $657,880,000$ & $417,725,855.25$ & $371,126,000$ & $566,592,095.43$ \\
\hline Earnings and Sales & $37,3295,000$ & $567,751,725.20$ & $5,154,212,000$ & $452,611,685.72$ \\
\hline $\begin{array}{l}\text { Rents on Government } \\
\text { Properties }\end{array}$ & $31,580,000$ & $5,102,605.64$ & $86,550,000$ & $14,711,518.57$ \\
\hline $\begin{array}{l}\text { Interest, Repayments and } \\
\text { Dividend }\end{array}$ & $51,949,000$ & $1,241,326.91$ & $678,856,000$ & $398,917,881.07$ \\
\hline Reimbursement & $146,888,050$ & $388,264.70$ & $501,032,000$ & $232,548,449.20$ \\
\hline Miscellaneous & $3,7021,000$ & $10,122,385.97$ & $73,770,000$ & $130,625,404.75$ \\
\hline $\begin{array}{l}\text { Statutory allocation from } \\
\text { Federal Government }\end{array}$ & $2,500,000,000$ & $3,961,995,580.37$ & $5,293,000,000$ & $10,361,347,647.03$ \\
\hline Total & $10,900,000,000$ & $18,687,684,541.41$ & $32,320,875,000$ & $21,958,446,745.63$ \\
\hline Source: Lagos State Government Auditor General Report on the Accounts of $2000($ October 2001$)$.
\end{tabular}


Table 5.14 shows the different avenues from which the state generates financial resources to pay for public services (and its ever-rising costs, which never seems to be enough in view of the increasing number of people ${ }^{101}$ in Lagos State) and to employ staff to supply such services. However, an interesting observation can be made on the revenue collected in 1999 and 2000 . The actual revenue collected in $1999^{102}$ was over 18.6 billion Naira, while the estimated revenue was 10.9 billion Naira. A surplus of over 7.7 billion Naira was generated.

However, in 2000 while the cumulative estimate was about 32 billion Naira, the actual revenue collected was about 21.9 billion Naira. This is a shortfall of about 10 billion Naira. Table 5.14 shows a decrease in State revenue collection despite the use of private consultants. It is unclear why the estimate and the actual diverged so drastically by over 10 billion Naira. The following may, however, explain the above observation. It may that the consultants overestimated their capacity and capability to collect revenue. Alternatively, there may have been a genuine drop in revenue, due in part to the resistance by the public to pay taxes and fines ${ }^{103}$. Another important but difficult to prove issue (as this was not systematically investigated), is the problematic relationship between private and public sector officials. The later may not cooperate, as they feel their jobs threatened or jeopardised ${ }^{104}$.

In his contribution, RSSG opined, "The government has to reduce the incursion and cost of external consultants. Develop and train the internal consultancy units of governments, like the Internal Audit Departments because they need to supervise and vet the works of these external consultants. Again all funds are internally generated now; the government must look for means to source for funds externally through Foundations or Trust Fund for some public services like education and sports".

Furthermore, one major source of the state government revenue is the statutory and non - statutory grants from the Federal Government. However, as earlier discussed there is a asymmetric allocation of Federal Government resources to the state governments and the responsibilities given to them. Supporting the need to decentralise power for more effective policy formulation and implementation, PSSIV remarked, "The idea of Federal Government using the same criteria for policies for the country in the name of uniformity, is oppressive. It will only lead to mismanagement of resources and increasing favouritism. The Federal Government must recognize the peculiar nature of Lagos State in funds allocation. Lagos State is very liberal. The Federal Government is aware of the situation in Lagos and the influx of people into the state. Therefore, it is unfair to continually use unrealistic socio-economic projection and base the funds allocation on this. Not only that, the federal should release these funds on time. Also the continual neglect of the federal facilities and infrastructure in Lagos its former capital is a very bad public policy."

PSSII believes that "The focuses of government both at the federal and state levels are not properly defined. The Federal Government does not take the peculiarities of particular state into consideration when making public policies. Most of the time most states governments would not want to deviate from the orders given by the Federal Government. For example, many of the changes made in the restructuring of government agencies were not properly defined to meet the states' goals. Further, there are no consistencies in the public policies. Also, the institutional capacities to effect government's policies are lacking. There are a lot of challenges and there is a need to make future plans.

\footnotetext{
${ }^{101}$ This phenomenon is caused by high rate of migration and birth-rate increase.

102 This was the year GVC12 came into governance and he used private consultants for revenue generation.

${ }^{103}$ There was wide-spread resistance to the use of private consultants fuelled in part by the high handed methods they employed such as locking up company premises when a firm defaults. Public outrage was reflected in a number of newspaper articles questioning this rather novel but unproven approach to public sector management.

${ }^{104}$ This fear materialised in 2005 as the state government retrenched many senior management staff of the Board of Internal Revenues. However, the researcher was not able to ascertain the number of officers affected.
} 
While the researcher still maintains that there is an imbalance between revenue allocation and responsibilities given to Lagos State, I believe that the state could make more efforts to rely less on the Federal Government for its revenue generation. Informant DS1's perspective in Box 5.4 aptly sums up the financial management of Lagos State Government.

\title{
Box 5.4: DSI thoughts on Financial Management
}

\begin{abstract}
" Many of the leaders were not pro-active or modern in their approach to financial management. For instance, look at the approach to budgeting. What you generate both internally and from the Federal Government is what you should spend is now outdated. Lagos is cosmopolitan, with about $10 \%$ of the population and $1 \%$ of the size of Nigeria in landmass. It has its own peculiar terrain, and majority of the industries in Nigeria. This calls for real budgeting opportunities that must be used to improve the finances of the state. The government lacked the political will to bridge all the tax leakages and revenue using modern approach to financial management. This could be turned around if consultants are brought in to identify all the various opportunities, design various approaches and train civil servants to carry out these new methods. Civil servants could be trained in this, with emphasis on attitudinal change backed with good leadership. Few of the political leaders have done this, for example GVC5. He reviewed the physical, land and taxes policies and he had more than enough to execute his projects.

The load the state is carrying outweighs its resources. So it cannot continue to use the old methods, it must adopt the scientific approach. One cannot feel the impact of government because of the population. For example, take the attendance at the General Hospital, vehicular traffic on the roads, and the peculiar terrain of the State. The people are running away from discharging their civic responsibility. Our laws are not helping matters. The laws do not affect people in the upper echelon. The environmental laws are not well promulgated. When I was Head of Research and Planning at the Ministry of Environment, it was discovered that less than $10 \%$ have approved building plans in Ikeja and Agege areas. This affects the revenue and the environment socially. We need to be responsible citizen. Also, the government should have the political will to carry out it responsibilities and change things for the better."
\end{abstract}

Source: The Researcher's interview during the fieldwork in 2003

\subsection{Organizational structure}

Another area that affected the institutional capacity and public service performance of the Lagos State Civil Service is organizational structure. Seven Ministries formed the nucleus of the Lagos State Civil Service in 1968: Finance, Education, Agriculture, Health, Labour, Local Governments and Internal affairs. Each Ministry had its specific functions and mandates. The overlaps in assignments of responsibilities were minimal, so it was difficult for one Ministry to blame another for work not done. Furthermore, the various Ministries had experienced staff for all functions. The government made efforts to co-ordinate the activities of the civil service by bringing majority of the Ministries and Departments to the newly constructed secretariat at Ikeja, the state capital. This made communication and coordination within the civil service fluid and easy.

Over the years however, the numbers of Ministries in Lagos State Civil Service rose to 43. Chart 5.6 depicts the changes. The Lagos State Civil Service had 13 Ministries in 1982; by 2002 , the number had risen to 43 Ministries, or an increase of 230\%. However, from 1968 to 1982 , the increase in the number of Ministries was only $86 \%$. Many resources are used to establish and maintain the infrastructure of these Ministries. The question is whether the money spent on the administrative structure could not have been spent on public service deliveries. 


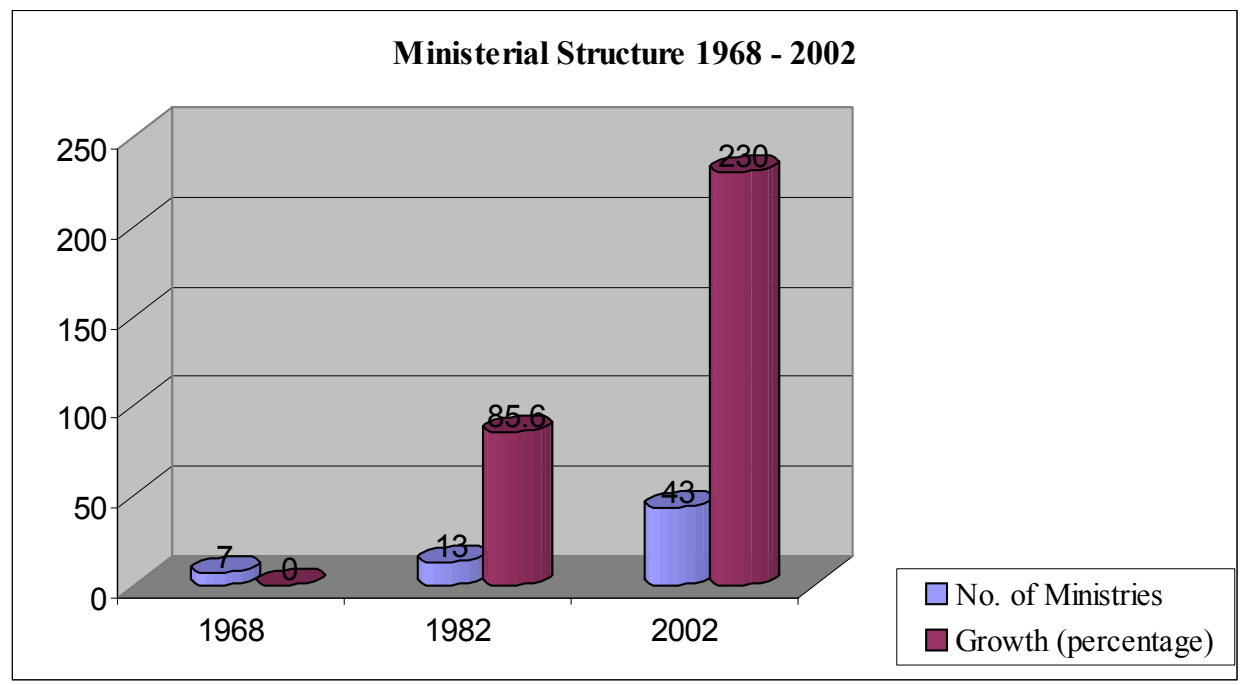

Source: Constitutionalism and Development in Nigeria- Lagos State Governance, Society and Economy by Dele Olowu, (1990: 49) and the Lagos State Public service Manpower Statistics (2002 Edition)

The size ${ }^{106}$ of the civil service is of great interest to researchers and financial institutions. The belief particularly of multilateral organizations such as the World Bank is that the government is too large, especially in sub-Saharan Africa. This view underpins a key requirement of the economic structural adjustment policies introduced by the financial institutions that government should reduce in size. However, there are two dynamics at play in the evolution of the bureaucracy in Nigeria. It has been observed that the Federal Government creates more states during the military regimes, while there is usually more restructuring of the state government during civilian regimes.

The Nigerian military is able to create states easily because it does not have to contend with the Parliaments. States are created by decree, often with little concern for their viability and sustainability. While civilian government is unable to create states easily, state Governors who regard the government as their "personal fiefdom" and want to compensate supporters and financiers with political appointments create more Ministries and Departments. Recruitment into politically motivated positions is not usually based on needs neither does it follow any labour development strategy. This leads to overlapping functions, as job descriptions are no longer as spelt out in the civil service rules and regulations. Usually, the civilian Governors aim to have the civil service to be truly subordinated to them. Where the Legislature is unable to provide checks, there is lack of accountability and transparency. Hence, in these situations, the Governor usually dominates the civil service and the government becomes wasteful, inefficient and bloated.

One of the factors that might have affected the astronomical growth in the size of the federal and state civil service in Nigeria is the populace's regard for government as an avenue to secure formal employment and as a way to gain political power among the contending po-

\footnotetext{
105 The staff strength of the State Public service between 1982-2002, and the composition of the Lagos State Civil service by salary grade levels as at December 2002 contrasted with 1982 Civil service establishment have been discussed in Chart 4.1 and Table 4.4, respectively.

${ }^{106}$ The ratio of workers and the staff strength has been discussed under human resources management above.
} 
litical and ethnic groups. They believe having representation in government will help in the socio-economic development of their areas, and such staff will do things that will favour their $\operatorname{areas}^{107}$. Unlike some developed countries, Nigeria's economy does not have a long history of private enterprises; instead, the government is involved in many activities that the private sector should be handling. Ultimately, the Federal Government and the Lagos State Government have become the first and second employers of formal labour respectively, in Nigeria.

Due to lack of effective organizational design, the Ministries are frequently renamed and restructured. Between 1993 and 2003, the Ministry of Establishments and Service Matters was reorganized and renamed four times. Once the name was changed because the serving Commissioner wanted to take the Department of Poverty Alleviation and Job Creation to the Ministry of Women Affairs to which she was re-posted. This demonstrates the fluid nature of organizational functions and the personalization of public purpose to conform to private gain $^{108}$. Other Ministries including Works, Lands, Environment, Political and General Administration are among the others that have gone through series of changes. The Ministry of Environment and Physical Planning is now Office of Environment and Office of Physical Planning, each with its own permanent secretary although a common Commissioner. These episodic changes always lead to waste, as stationeries are changed, and new furniture acquired. The Ministry has to be redesigned and repartitioned to make room for the new Departments being created.

Another area of rewarding personal and political loyalty is through the creation of the Office of the Special Adviser with all its paraphernalia within the Ministries. For example, there are offices of Special Advisers on Education and Local Government within these Ministries. The boundary between Ministerial responsibilities is questioned, which often leads to tension between the Commissioner and the Special Adviser, and between the staff because of the conflicting loyalty and trust of staff to different bosses. What are the roles of the Permanent Secretaries in these? The constant tension between senior civil servants and political appointees sometimes develops into distrust and suspicion that inhibits performance, and ultimately affects the Ministerial goals and objectives ${ }^{109}$. In Table 5.17, although $38.2 \%$ of the respondents considered the government not excessive; a majority of the respondents think otherwise and they gave various reasons including: appointments are based on political consideration $(30.1 \%)$, and government appointments are based on whom you know and not on competence (16.9\%). According to RPSII, "There are too many people in the service and there is no pyramidal structure; it is top and middle heavy, and down thin."

Table 5.15: Is the Size of Government Excessive?

\begin{tabular}{l|c}
\hline Label & Percentage \\
\hline That is not true & 38.2 \\
\hline Appointments based on political consideration & 30.1 \\
Yes, government appointment based on who you know and not on competence & 16.9 \\
High unemployment forced the civilian government to do massive recruitment & 14.8 \\
Total & 100.0 \\
Source: From the research survey in 2003 & \\
& \\
& \\
107 & This issue is further discussed under the patrimonial disposition of the state. \\
Political appointees such as Commissioners often excise Departments or programmes if there is a likelihood \\
of personal gains. This was the case in this particular example. \\
A lot has been said about the relationships between the political and administrative leadership at the begin- \\
ning of this chapter; see also Chapter six on Civil Service Reforms and Public Service Performance.
\end{tabular}


In his comments, PSSIII said, "Although the scope of work has increased beyond imagination, the Ministries have been turned into octopus with too many parts. Many Ministries were excised from existing ones. For example, the Ministry of Environment and Physical Planning has been divided into two. Likewise Ministry of Works is now divided into Ministry of Works and Ministry of Infrastructure. The Pension Directorate has been transferred to Ministry of Economic Planning (this movement might be justified because of the pension scheme). However, the establishment of many of these Ministries cannot be justified, except to say that it is to give the politicians work. One needs to ask for the schedule and what they do in some of these Ministries and Offices. Sometimes Special Advisers are given the positions of Permanent Secretaries. The establishments of too many Ministries are not cost-effective."

In view of the number of people that have to share the existing infrastructures like working environment, office supplies (papers, photocopying machines), and physical infrastructure such as water, electricity and telephone, secretariat support and Internet and computer, respondents rated many of the infrastructures as being average or low. There is a general dissatisfaction with the quality of office equipment. Many of the newly employed staff do not have facilities to work with, while the political appointees insist on big and well-furnished office that are equipped with the latest gadgets, many of which are never put to profitable use, but are purchased largely to impress their constituency when they come to visit.

Table 5.16: Infrastructural Factors Affecting the Quality of Lagos State Civil Service.

\begin{tabular}{|c|c|c|c|c|}
\hline Percentage & High & Average & Low & Total \\
\hline $\begin{array}{l}\text { Provision of adequate and decent work envi- } \\
\text { ronment }(\mathrm{N}=149)\end{array}$ & 17.4 & 67.8 & 14.8 & 100.0 \\
\hline $\begin{array}{l}\text { Provision of office supplies (papers, photo- } \\
\text { copying machine, etc) }(\mathrm{N}=147)\end{array}$ & 10.9 & 46.3 & 42.9 & 100.0 \\
\hline $\begin{array}{l}\text { Provision of physical infrastructure } \\
\text { Water }(\mathrm{N}=149)\end{array}$ & 17.4 & 65.1 & 17.4 & 100.0 \\
\hline Electricity $(\mathrm{N}=149)$ & 17.4 & 75.8 & 6.7 & 100.0 \\
\hline Telephone $(\mathrm{N}=149)$ & 22.1 & 63.1 & 14.8 & 100.0 \\
\hline Secretariat support $(\mathrm{N}=148)$ & 18.2 & 66.9 & 14.9 & 100.0 \\
\hline Internet \& Computer Support $(\mathrm{N}=149)$ & 10.7 & 42.3 & 47.0 & 100.0 \\
\hline
\end{tabular}

Source: From the research survey in 2003.

In Table 5.16, 75.8\% of the respondents rated electricity as average because of the epileptic power supply in the government secretariat, which is hooked up to the National Electric Power Authority (NEPA). NEPA has the national monopoly mandated to generate and supply electric power. However, this Federal Government institution has not been able to produce enough to satisfy demand. A situation that leads to constant power failure in the secretariat and this affects productivity, as a lot of machinery such as the computer, photocopying machines, and air conditioners have to stop working during power outage. This has made some offices like the Governor's Office, SSG, HOS and some other Ministries to be almost permanently hooked to the private electricity power generators.

The provision of adequate and decent work environment came second on the average rating with $67.8 \%$. The respondents believe that this has a major effect on the quality of the civil service. Civil servants think that the political appointees are gradually marginalizing them and they have to rely on inadequate resources to do their work. This situation arises because recruitment is carried out without adequate consideration for physical infrastructure. The respondents rated secretariat support as the third on the average rating with $66.9 \%$. The disproportionate ratio distribution of 2:1 between middle management and the junior staff has 
much to do with this rating. Most of the typists and secretaries that give the secretariat support are in the junior cadre. This leads to a lot of tension and some of them are overwhelmed with work as they try to satisfy many superior officers at the same time.

The institutional capacity of government has been greatly undermined by the three factors discussed above, namely, (i) human resources management policies; (ii) finance and economic policies and the (iii) organizational structure of the civil service. These have subsequently affected the ability of civil service to implement government's policies and public service deliveries are adversely affected. The issue of poor service delivery has led the various governments to want to revamp the civil service through the introduction of different reforms, an issue that is discussed in the next chapter. 


\section{Civil Service Reforms and Public Service Performance}

The Nigerian Civil Service needed reform to improve its performance and promote transparency and accountability in government. The concept of Civil Service Reform connotes transformation in terms of structure and behavioral patterns of government in order to enhance performance. Success hinges on the institutional capacity and capability of government to undertake such reforms. The Nigerian Government, like many other African countries in the mideighties, started experiencing stagnation in its economic growth and a decline in the standard of living of its populace. A variety of economic recovery programmes were proposed and the one adopted by the Nigerian Government was the Structural Adjustment Programme ${ }^{110}$. According to Ayeni, (1992:2) "This package of economic reform measures rests on the assumption that the African economy can be turned around through the achievement of fiscal and external balances and the free play of market forces."

It was soon noted that the economic consideration alone was an inadequate answer to the problems of Africa. Underlying the structural disarticulation observed in these economies were deeper issues that relate to institutions, political pluralism, participatory democracy and human rights. Although the SAP was undertaken at the insistence of the World Bank and other international financial institutions, it was believed that there was an urgent need to reform the government bureaucracy that would implement the economic restructuring measures. As such, the reform is part of the long sequence of reforms that Nigeria in general and Lagos in particular undertook.

\footnotetext{
${ }^{110}$ The impact of the Structural Adjustment Programme has been discussed earlier.
} 
Table 6.1: Nigeria: Indigenous Civil service Reforms, 1934-1994

\begin{tabular}{|l|l|l|}
\hline & Year \\
\hline Hunts Commission & 1934 \\
\hline Harragin Commission & 1945 \\
\hline Foot Commission & 1948 \\
\hline Phillipson- Adebo Commission & 1954 \\
\hline Gorsuch Commission & 1954 \\
\hline Mbanefo Commission & 1959 \\
\hline Morgan Commission & 1963 \\
\hline Eldwood Commission & 1966 \\
\hline Adebo Commission & 1971 \\
\hline Udoji Commission & 1972 \\
\hline Dotun Phillips & 1985 \\
\hline Decree No. 43 & 1988 \\
\hline Ayida Review Panel & 1994 \\
\hline Sources: Ikejiani-Clark (1997); Williams (1997). As produced in Reforming Africa's Institutions- Ownership, \\
\hline Incentives, and capabilities Edited by Steve Kayizzi-Mugerwa. Tokyo, United Nations University Press: p.172, \\
Table 8.1
\end{tabular}

Table 6.1 shows all the indigenous Civil Service Reforms by the Federal Government of Nigeria from 1934 to 1994. Since its inception in 1967, the Lagos State Government participated in the following reforms: Adebo Commission (1971), Udoji Commission (1974), Dotun Phillips (1985), Decree No. 43 (1988), and Ayida Review Panel (1994).

\subsection{The 1971 and 1974 Civil service Reforms}

Nigeria has undertaken many different reforms since 1934 as indicated in Table 6.1. The majority of these reviews focused on salaries, wages and conditions of service, such as the review by the Adebo Commission of 1971. The Udoji Commission of 1974 was more comprehensive and developmental in nature, and is also known as the Public Service Review Commission. This Commission articulated far-reaching suggestions for a result-oriented public service. Its Report became a basic reference document to various aspects of the public service including training, wage and salary reviews. It examined structural defects in the civil service that could impede its efficiency and effectiveness.

The Report was the first to recommend the professionalization of the public service, in order to enhance competence and performance of the public servants. A particular area of interest is the administrative professionalism of the management cadre. Accordingly, these officers would "possess requisite skills and knowledge, and can function effectively in applying skills and knowledge to establish goals and achieve results. The professional civil servant is a specialist in a particular field...." (Public Service Review Commission, 1974:7). It is opined that the administrators who are regarded as generalists are "Jack of all trade" and therefore "master of none" could impede public service development. It is expected that the administrators will develop expertise in particular area of tasks they perform. The implementation of public service professionalization is one of the most controversial reforms and remained very problematic to implement as will be discussed under the 1988 Civil Service Reforms. 
Another major area of interest in the 1972-1974 Public Service Review Commission Report is the staff development and training component. This entails policies and procedures to enhance job skills and evaluation to have an efficient utilization of labour and improve public service performance. The Report tried to correct some deficiencies of the existing public service training programme and made several propositions. Promotion should be tied to training, with the hope that all categories of staff would have the opportunity to be exposed to more varied and appropriate training. Specialized trainings for particular areas of the service were emphasized. Training institutions needed review and expansion to aid the developmental efforts of the public service. However, many of the laudable management techniques suggested 'suffered implementation neglect', and emphasis seemed only to be on wage and salary reviews. The government implemented only those recommendations that related to wage and salary increases because it wanted to win the goodwill and support of workers.

After the evaluation by the Udoji Commission, the government took a course of action that nearly led to the collapse of the civil service. According to Adebayo (2001:213) "The reason can be traced to the great purge of 1975 followed by another purge in 1984. Never in the history of any human public organization had so much havoc been wreaked on the organization by a ruthless decimation of its labour force. Without establishing any rational basis or any ascertainable reason, about ten thousand civil servants were thrown out, a good many of them being the cream and the best in the service. This exercise destroyed morale in the civil service, led to frustration and uncertainty and inevitably shattered productivity and efficiency since many good ones were thrown out and those who remained lost their morale and sense of devotion to duty."

\subsection{The 1985 Civil Service Reforms}

The arbitrary staff dismissal by the Federal Government in 1975 and 1984 affected the career paths of many civil servants. These were periods of military regimes, and dismissed officers who made recourse to the legal system, whose rulings were more often than not ignored. As a rule, the military is not noted for obeying court orders. Thereafter, it became the norm as due process for exit of staff from the service was ignored repeatedly. The Civil Service Commissions both at the federal and state government levels have no power to prevent the blatant disregard for rules and regulations by those in power. The mass retrenchment exercises carried out by the Lagos State Public Service between 1999 and 2000 did not have the input of the Lagos State Civil Service Commission ${ }^{111}$. Executive Governors, without any recourse to rules governing appointments and dismissals, dismissed several higher civil servants. This government action helped to destroy the morale of staff, which led to frustration and uncertainty.

It is no wonder then that after the 1974 Udoji Commission that was set up to put the Nigerian Public Service back on course of productivity and efficiency, the service was near total collapse. The Federal Government had to institute another Commission in 1984 to review the Federal Civil Service. Professor Dotun Phillips headed the Review Panel. Justification for the 1984 Civil Service Reform included a further need to strengthen the civil service capacity through professionalism, accountability and transparency. The Report of the Panel was submitted in September 1985, but the Panel's recommendation finally came out as Decree 43 of 1988 and the implementation of the reforms started thereafter. The delay was due in part to the coup d'état that took place in late August 1985 and the new military government needed to establish itself. Further, the government wanted to stop the economy's decline by executing

\footnotetext{
${ }^{111}$ In Lagos State due to the avalanche of petitions that ensured after the retrenchment a committee was set up, however, the outcome and the specific remunerations made to individuals are not known.
} 
the mentioned Structural Adjustment Programme enforced by the World Bank and other financial institutions.

The new government soon noted that it needed a performing bureaucracy to implement its economic restructuring measures. The Federal Government therefore decided to reorganize the Nigerian Civil Service based on the Report of Study Team on the 'Structure, Staffing and Operations of the Nigerian (Federal) Civil service' of Dotun Phillips Panel of 1985. President General Ibrahim Babaginda established an implementation Task Force on the Civil Service Reforms under the chair of Chief of Naval Staff, Vice Admiral Patrick Koshoni. The modalities for implementing the reforms came out as Decree 43 of 1988 on Civil Service Reforms and this applied to all Ministries and Extra-Ministerial Departments, state civil services and local governments. Commencement date was April 1, 1988.

Part of the justification for the 1985 Civil Service Reforms by Dotun Phillips ${ }^{112}$, was the need for the civil service to develop effective policy formulation, coordination, implementation and evaluation. This required that:

- The locus of the final decision-making is clear and unambiguous;

- Responsibility and authority are never separated;

- The policy-advisers are clearly competent and expert;

- The institutions which directly involved in making major sets of policies are coordinated structurally and not just ad-hoc;

- The organization concerned has full command and control over its staff;

- Performance evaluation is undertaken regularly at institutional and individual staff levels, and serve as the major basis for reward and sanction;

The Chief Executive of the country is not a peripheral or residual (but a central) actor in the management of the economy.

The reason for the above justification is the assumed conflict and confusion that characterised decision making at the upper echelon of the civil service ${ }^{113}$. Dotun Phillips' reforms also emphasized such issues as performance-productivity related pay, review of performance appraisal of staff, re-evaluation of the information management system, improvement in record keeping, professionalization, training, conflict between professional and administrative class $^{114}$. Other concrete recommendations included "the need for the Federal Government to articulate the expected role of the Federal Civil Service more sharply and comprehensively, make more investment in the service, restrict itself to general directive activities while leaving other socio-economic development activities (such as rural development, agriculture, water development, housing, social development) to states, local governments, cooperatives and the private sector; the exclusion of the Nigerian Police Force from the civil service, the allocation of $10 \%$ of the personnel costs to every Ministry to mandatory training..." (Olowu, 1992:136).

Critics argued that Decree 43 of 1988 did not consider some of the crucial recommendations of the 1985 Study Team Report. This may be due to difference in the two groups' terms of reference. The 1985 team, constituted under the Buhari regime ${ }^{115}$, was interested in 'rationalization' and restructuring due to the presumed over-staffing of the public service. However, part of the rationale for the 1988 Civil Service Reform was to have an efficient bureaucracy to implement successfully its Structural Adjustment Programme, within the shortest period, and to align the civil service with the Presidential Model adopted by the Nigerian Government in

\footnotetext{
${ }^{112}$ The full text is in the chapter "Elements and Justification" in the book edited by Victor Ayeni on Civil Service Transformation for Structural Adjustment 1992, published by Nigeria Institute of Management.

${ }^{113}$ This issue is discussed in detailed under Permanent Secretaries below.

${ }^{114}$ These were some of the issues also dealt with by the Udoji Commission of 1972 but which lacked adequate implementation and enforcement.

${ }^{115}$ The federal Government under the Buhari regime removed an estimated 45,000 public officials from the federal Civil service alone between 1984-1985 (Olowu, 1992:137)
} 
$1979^{116}$. Therefore, some of the elements of the 1985 proposals implemented by the 1988 reform were those that would presumably assist the Ministers in programme execution, avoid delays in project implementation; make policy management clearer and less ambiguous, and achieve its objectives of the structural adjustment within a short time.

\subsection{The 1988 Civil Service Reform}

During the 1988 Budget speech, then President General Ibrahim Babaginda informed the nation about the major reforms that would take place in the Nigerian Civil Service. During the speech, he articulated the canons of the reform. In Lagos State, the Secretary to the Military Government convened a meeting of the Permanent Secretaries on January 29, 1988. The meeting noted the apprehension, uncertainty and insecurity that the President's speech had generated amongst civil servants. It was therefore decided that a Study Committee of seven Permanent Secretaries should be constituted to "brainstorm on the reforms so that if and when the Federal Government called for the inputs of state government, it would be possible for the state government to present a collective view point" ${ }^{117}$ (Adeyemi 1992). The committee met in February 1988 under the following terms of reference:

- To examine the civil service reforms as they may affect the State Civil Service;

- To identify likely problem areas in the implementation of the reforms, and

- To proffer possible solutions to the problems.

However, the request for input from state governments or consultation with the committee of Secretary to Military Government or Heads of Service by the Federal Government never came. The Federal Government, with the instruction that all ministries and extraministerial departments, state civil service and local governments, should commence implementation by April 1, 1988 announced Decree 43 of 1988 Civil Service Reforms.

The 1988 reform of the civil service led to major institutional changes and profoundly impacted the government's capacity. This study deals with the major aspects of the reforms and its subsequent impact on the performance of the civil service in the following areas:

- The post of Permanent Secretary to be political and designated as Director-General. The term to end with the government that appoints.

- Ministers or Commissioners to become Chief Executives and Accounting Officers of their respective Ministries.

- Abolition of the position of Head of Service.

- Ministerial restructuring and professionalization.

- Each Ministry or Department to employ, promote and discipline its own staff.

\section{Permanent Secretaries}

One of the major aspects of the reform was that the position of the Permanent Secretary should become political and redesignated as Director-General. To promote the injection of new ideas into the system, the appointed Director-General could be from outside the civil service. The decision to have the appointments conclude with the administration that selected them, was to reduce the potential tension level and conflict between the Minister or Commissioner and their Permanent Secretaries during the process of decision-making. This harmonises with the sentiment that the political leadership is accountable to the President and the

\footnotetext{
${ }^{116}$ A good discourse on the 1988 Civil service Reforms is contained in the book edited by Victor Ayeni on Civil service Transformation for Structural Adjustment 1992, published by Nigeria Institute of Management.

${ }^{117}$ F.A.O.Adeyemi did a write up on the "Implementation of the Civil service reforms in Lagos State" in the Civil service Transformation for Structural Adjustment 1992, published by Nigeria Institute of Management.
} 
populace for his performance, but he has no absolute control over the human and material resources to achieve his mandate. In contrast, the Permanent Secretary is a career bureaucrat and is the accounting officer in charge of the resources needed for the effective performance of the Ministry. There is a sharp division between responsibility and authority.

The Minister or Commissioner is a political appointee and therefore has a term of office relative to the government that appoints him, but inherits the Ministry's Permanent Secretary. Problems start if there is a conflict of interest between these officials, and this ultimately affects policy formulation and implementation. This according to Phillips, (1992:16) leads to "a situation in which the locus of responsibility was separated from the locus of authority... The overall result was a largely ineffective policy management both at institutional and national level." By making the Ministers and the Commissioners the accounting officers, they have both the responsibility and the authority. Nevertheless, efforts should be made to put qualified people in these political positions.

Furthermore, as the position of the Director-General is a political one, it encourages to forge an alliance with the Minister or Commissioner and to support their policies and advise them on governmental decision-making. He or she will also be the bridge between the political and the administrative leadership. To nullify the role of the Director-General as a gatekeeper, the Minister and Commissioners could have direct access to the Directors in the various Departments. Thus, the political leaders avoid becoming "prisoner" to their DirectorsGeneral. This restructuring should lead to loyalty and commitment on the part of the DirectorGeneral - important attributes for "speedy and effective policy advice and implementation". This would also protect the higher civil servants from "political buffeting" of mass retirement which had been a regular feature of succeeding governments since the mid-seventies ${ }^{118}$ (Phillips 1992).

According to the critics of the reform, this weakened the traditional structure of the civil service as it undermined the position of the administrative heads of the Ministries. Depending on the relationship between the Commissioner and the Director-General, the latter may not know what is happening in his Ministry (who is supposed to be the repository of knowledge in the Ministry), since the Commissioner could by-pass him to discuss important issues directly with heads of Directorate. Further, his knowledge about the activities in his Ministry is reduced as all correspondence is now made to the Commissioners. This eventually leads to lack of coordination between the Director-General and his Directors. Further, this may disrupt record keeping and accountability with the ultimate upset in continuity.

The politicisation of the Director-General post had the unintended consequence of high turnover of the civil service's upper echelon and the depletion of competent and experienced officials with every change of government, except in cases where the new government decided to retain some of these staff. Sometimes members of the political parties, who most of the times were inexperienced or ill qualified, were recruited. Further, the instability of the Directors-Generals' tenure (since they knew that they could be arbitrarily dismissed or the government sacked by another military coup without adequate compensation) also led to lack of probity and the need to acquire a strong material base for themselves, contrary to the tenet of propertylessness of a true public servant. This affected the morale of other workers as they realised that aspiration to the highest position of their career could get them out of the civil service before the stipulated time for retirement.

In his comments, GVM8 remarked that the

"1985 Civil Service Reforms of Professor Dotun Phillips recommended that the post of the Director-General should be political and that they should retire with the government that appointed them was really bad for the system. Promotion is an acknowledge-

\footnotetext{
${ }^{118}$ This is one of the assumptions of Dotun Phillips Committee's consideration for its subsequent recommendation.
} 
ment of good work. It was not supposed to be based on family ties or political affiliations. If you are good, you should know that you would eventually get to the position of the Permanent Secretary, which is the top most in the career of the civil servants. Making the position political demoralised the system, and made the civil servants to become sycophants to the political leaders."

DSSI stated "The Civil Service Reform of 1988 rather than improving the civil service produced a lot of problems. The change from Permanent Secretary to Director General created a great gap in the morale of hardworking staff. The civil servants see the position of the Permanent Secretary as the ultimate in their career." According to PSSII, "The 1988 reforms allowed politicians to act as Directors-General over and above professionals. Many of them do not know what the job entails. This led to a psychological set back for the staff and the civil service suffered. Common man came in and took over." Adding to this, RSSG informed, "The Civil Service Reforms negatively affected the service. The politician found the chance to exercise some powers over the bureaucrats. Director-Generals were sidelined, Commissioners communicated directly with the Directors. Information is power. The Director-generals were no longer in position to monitor what was happening. The high-level person was now a passenger in the boat. Administrative staff saw it as an attack on their position." This politicisation of the higher civil servants did considerable damage to the system.

\section{Ministers and Commissioners}

Ministers and Commissioners at the federal and state levels became the Chief Executive and Accounting Officers. With the new system they received the responsibility and the commensurate authority. It was hoped that this would resolve the ambiguity as to who really was in charge of the ministry. The lack of clarity in decision-making had often led to inefficient project and programme implementation (Phillips 1992).

Critics argue that making the Ministers and the Commissioners accounting officers was to the detriment of the service as political appointees' enhanced patrimony. Commenting on this, Adebayo (2001:214) opined, "The decision to make the Minister or Commissioner the accounting officer of his Ministry led to financial recklessness and outrageous corruption. The checks and balances, which operated when career civil servants were accounting officers, were no longer there. Ministers or Commissioners were political appointees who were in post for only a brief while and were intent on making as much money as they could." Civilian rule in 1999 abolished this system, restored the position of the Permanent Secretary and again made them Accounting Officers.

\section{Head of Service}

Another element in the 1988 Civil Service Reform was the abolition of the position of the Head of Service, leaving each Department to its own whims and caprices. The Head of Service is like the "spiritual" head of the civil service, a person that the whole staff can turn to for guidance and direction. The persons are usually appointed on their ability to enforce discipline, rules and regulation. They usually have a good reservoir of knowledge on the history of the civil service and are expected to use it effectively. They have a realistic assessment of the civil service's capacity and coordinate the activities of the various Departments. They should have the ability to lead and inspire the staff through their hard work, brilliance and uprightness. Some of the assigned responsibilities of the Head of Service in the Lagos State Civil Service are:

- Providing leadership and direction to the civil service by maintaining high morale, espritde-corps and a good image of the service; 
- Fostering professionalism among civil servants;

- Advising the State Chief Executive of the appointment, posting, and deployment of Permanent Secretaries;

- Posting of civil servants of all cadres (Admin, Professionals, Sub-Professionals and the centrally-deployed cadre);

- Appointments, deployment of Chief Executives of Parastatals

- Vetting of appointment and posting of Heads of Departments of Governments;

- Service welfare matters, among others (Lagos State of Nigeria Official Gazette, 2001). Source: Lagos State of Nigeria Official Gazette, 2001.

Seventeen Secretaries to State Government and Heads of Service have been at the helm of affairs in Lagos State. Table 6.2 shows under which political leadership they served.

Table 6.2: Lagos State: List of Heads of Service and Secretaries to the State Government, 1968-2005

\begin{tabular}{|c|c|c|c|}
\hline $\mathbf{S} / \mathbf{N}$ & $\begin{array}{l}\text { Head of Service/ Secretary to } \\
\text { the State Government }\end{array}$ & Political Leadership & Dates \\
\hline 1 & SSG1 (deceased) & GVM1 & $1968-1973$ \\
\hline 2 & SSG2 & GVM1 & $1973-1975$ \\
\hline 3 & SSG3 & GVM2 (deceased) & $1975-1977$ \\
\hline 4 & SSG3 & GVM3 & $1977-1978$ \\
\hline 5 & SSG4 & GVM4 & 1978-1979 \\
\hline 6 & HOS5 & GVC5 & $1979-1983$ \\
\hline 7 & SSG6 & GVM6 (deceased) & 1984-1986 \\
\hline 8 & SSG6 & GVM7 & 1986-1989 \\
\hline 9 & SSG7 & GVM8 & 1989-1991 \\
\hline 10 & HOS8 & GVC9 & $1991-1993$ \\
\hline 11 & SSG9 & GVM10 & 1993-1994 \\
\hline 12 & SSG10 & GVM10 & 1994-1996 \\
\hline 13 & SSG11 & GVM11 & 1996-1998 \\
\hline 14 & HOS12 & GVM11 & 1998-1999 \\
\hline 15 & HOS13 & GVC12 & 1999-2004 \\
\hline 16 & HOS14 & GVC12 & $2000-2005$ \\
\hline $17^{*}$ & SSG15 & GVC12 & 2004- 2006 \\
\hline
\end{tabular}

Source: Office of the Head of Service, Lagos State Government.

* Notes: The terms, Head of Service and Secretary to the State Government were used during civilian and military regimes for the administrative head of the staff, respectively. In some rare cases, these could be from outside the civil service like SSG8. GVM11 and GVC12 made these into two distinct positions, with different people occupying the position of the Head of Service and the Secretary to the State Government.

RPSIII opined, "The abolition of the position of Head of Service was really a fatal blow to the civil service. The HOS gives direction to the staff. He or she should be in control and have an agenda on how he or she will gear the civil servants into getting things done. The aim is to get the staff to work and give of their best. The person in charge of the staff is the HOS, and the civil servants get their encouragement from him/her."

Recounting the role of the HOS and the SSG at the establishment of the Lagos State Civil Service, DSI said, "The SSG1, was highly respected because he was focused and 
equally a seasoned administrator. He mentored HOS5, the person that became HOS during the Second Republic. They did excellent work. They marshalled ways by which to move the state government forward. There was fair play and discipline. Later, the administrative leadership lost direction. By 1989, the SSG7 then could not wish away what had been done. Secondly, she was not too long as Secretary to the State Government to do magic. A decade later, HOS13 did not help the system much. There is a need for amendment. The morale of staff is very low. Postings were made that have no bearing on individual skills. People had now taken to making money."

RPSI believed that "The likes of the SSG1 and HOS5 spent all their lives to build the civil service, and all their labours are now wasting away. We must put people who have integrity and enough knowledge of the civil service in position of power. They must have enough courage to dictate where the staff should go and serve. Some of these officials that had shown exemplary traits are SSG7 who was visionary and God fearing. She wanted to raise the quality of the civil service. SSG10 was able to hold the civil service together during the turbulent political period of 1994. SSG11 wanted to bring back the era of seniority in the civil service in terms of elevating the deserving staff to the post of Permanent Secretary."

\section{Ministerial Restructuring and Professionalization}

Another significant feature of the 1988 reforms was Ministerial restructuring and professionalization of the civil service. According to proponents of the reform, the strategy of professionalization is pertinent in order to cope with complex functions of modern government as the professionals have important function to play in the successful operation of things. His competence aids the efficiency and effectiveness of the organization. The Dotun Phillips reforms' emphasis on professionalization created Departments that were more functional. The maximum number of Directorates any Ministry could have was five operational and three mandatory Directorates, namely, Personnel Management, Finance and Supplies, and Planning, Research and Statistics depending on the functions of the Ministry. Civil servants were requested to make a career in one Ministry and thereby develop expertise in a particular schedule of function, instead of moving around the various Ministries and becoming a generalist.

This aspect of the reform is mainly targeted at the administrative and executive staff members that were generalists before and in charge of management of the resources and policy formulation. To reflect the professional structure of the Ministries, new nomenclature that reflects the staff duties was established. A staff member could be an Assistant, an Officer or a Director. One of the main features of this system was the compulsory training of officers in their area of specialization. "Unlike in the past when staff training was sporadic, anaemic and arbitrarily selective, training has become the right of a civil servant and an obligation on government" Phillip, (1992:19). The Committee system, an essential part of teamwork, must thereafter be encouraged whereby policy-formulation and policy-execution is the work of all professionals and specialists in the Ministry.

Critics of this aspect of the reforms opined that the idea of professionalization of the civil service is laudable and could contribute to better performance of the civil service. This is a popular development in public administration. However, according to Ayeni (1992:29) "Just as much as it is desirable, evidence abound to show that professionalism often runs counter to several equally vital elements of modernisation. The result is that effort to professionalise tends to give rise to distortions and tensions in other facets of life. This predicament is not an easy one. A poor handling of it can in fact retard organizational progress rather than improving them." In the Lagos State Civil Service, the practical application of the reform led to several difficulties that eventually affected the performance of the civil service, contrary to the earlier intention of the reorganization. 
One of the ultimate aims of professionalization is that all professionals and specialists would make policy formulation and implementation, and that the administrative class would no longer have monopoly over public policies. Many of the professional and technical staff saw this as a way of breaking the barrier into policymaking positions, which the administrative staff earlier saw as their own purview. Although, some professionals earlier had the opportunity to be Permanent Secretaries and Directors in their various Ministries.

Some of the informants believed that the professionalization of the civil servants had a positive effect on staff performance. In her comment, PSSI Stated, "One of the government policies that affected the civil service positively is the professionalization of the staff. This reduced the generalists in the service many of whom are mixed matches." Commenting along the same line, PSSII said, "The reforms encouraged professionalism in the civil service, but it went beyond it scope. I still believe that the head of Ministries should still be an administrator who is a generalist that knows a bit of all the different areas. For example having an engineer as the head of Ministry of Works or a medical doctor as the head of Ministry of Health is not very good. They could be narrow-minded. They will always be bias against other professionals in their Ministries. When a generalist was head of Ministry of Works more work was done than now. A professional must terminate as a Director. A Permanent Secretary must be able to work anywhere. The 1988 reform was supposed to encourage competence and merit. It worked the other way round."

The dichotomy between generalists and professionals goes beyond the comments made by PSSII above. ${ }^{119}$ It is an historical problem that inherited from the colonial era, which must be corrected in order for efficiency to be enhanced in the process of public policy formulation and implementation. As Adebayo, (2001:163) aptly puts it, "senior public officers, specialists, and administrators must therefore orientate their thinking to appreciate that the presence and interaction of both is a necessary and indispensable fact of public administration, and must therefore devise ways and means of peaceful co-existence" in order for the system and the overall society not to suffer.

The Ministerial restructuring also recommended that there should be a stop to the transfer of staff between Ministries. All staff must make a career in a single Ministry and there was the establishment of more functional and operational Departments. This reorganization created many supervisory positions. Many officers were placed in positions they were not qualified or trained for, while qualified officers were under-utilized in other Ministries. This ultimately affected the quality of advice given to the government and the quality of work produced by such Departments. In order to implement this recommendation, some Departments and Ministries had to employ new hands in order to fill the newly created posts, ignoring the resource of experienced staff under-utilised in other Departments.

Commenting, PSSIII reflected that, "The Civil Service Reforms made the expansion of the civil service possible as it allowed for more people to be employed. The creation of many Departments made it possible for many individuals on grade levels 13 and 14 to be promoted to the Director's level ${ }^{120}$. Many of these people were not professionally ready for the tasks they were being exposed to." In her own contribution, RPSII opined that "centralized posting of staff or "pool system" like the one done for the administrative cadre, helps the staff to gain experience and working knowledge of the various Ministries." RPSIII believed that, "Some Staff saw the concept of professionalization as a means of financial benefits and selfenhancement. Many wanted to become Director, Finance and Supplies, and not of Planning, Research and Statistics. Staff now concentrate on working for themselves instead of working for the system. Staff lobby to be posted to perceived "lucrative" Ministries like Works, Edu-

\footnotetext{
${ }^{119}$ Adebayo (2001) in his book Principles and practice of Public administration in Nigeria discusses this matter in his chapter on "The problem of the administrator and the Professional Expert in the Public service of Nigeria.

${ }^{120}$ This means that a step or two that should have been made between seven to ten years have been jumped.
} 
cation, Lands and so on. Objectives were not well defined. Seniority and experience did not matter. Anybody could be put anywhere. People were also brought in who are not well versed in policy administration. All these affected the quality of the performance in the various Ministries."

\section{Civil Service Commission}

Another reform alteration was in the role of the Civil Service Commission. The appointments and promotions were given to the various Departments, although a member of the Commission would be in attendance to ensure compliance to rules and regulations. According to the reform, the Ministries were no longer under the expressive control of the Civil Service Commission or the Head of Service (who was in charge of posting officers), resulting in actions that sometimes led to "great uncertainties and instability in the staffing position of Ministries" Adebayo, (2001). By this, the Ministries now had full control over their staff and this would ensure staff loyalty to their various Ministries. Since the position of the Head of Service is no longer essential, it should be scrapped.

The implementation of this recommendation led to some negative consequences, as many arbitrary and improper appointments diminished the standard of recruitment. When the role reverted to the Civil Service Commission, much harm had been done to the system. Members of the Commission were no longer apolitical, as they want to fill the available vacancies with their kith and kin. Ministerial appointment also led to the ineffectiveness of the Audit Alarm System, the unit originally established to enhance accountability and transparency. The Audit Departments were answerable to the Auditor-General. By the time the Ministries started hiring some of its staff, the loyalty of the staff was more to the Ministry and the Commissioner that hired them and this eventually affected the efficiency of this unit.

\subsection{The Government White Paper of 1997}

In 1994 the Ayida panel was constituted to readdress the apparent distortions of the 1988 Civil Service Reforms. Adebayo (2001:216), quoting the introductory remarks of the panel, said, "in the course of this exercise, we have found that the Nigerian Civil Service, as an effective and dependable institution, has virtually broken down". The panel's white paper came out in June 1997 and reversed some of the 1988 Civil Service Reforms' recommendations, but by then the system had already been badly impaired.

Lagos State Government set up an inter-Ministerial committee to look into the recommendation and advise the government accordingly. Many of the recommendations were accepted. One of them is that "Ministries and extra-Ministerial Departments should be structured according to their objectives, functions and size and not according to a uniform pattern" (Adebayo, 2001:216). This is mainly to contain the expansion of the civil service and avoid the system bloating up again. However, an interesting situation happened in Lagos State Civil Service: from 1999 to date, about seven Ministries have restructured, reorganized, split, renamed and expanded. Reasons for this are discussed in chapter 5 under organizational structure.

For example, the Political and General Administration, the Ministry that services the Office of the Governor was restructured into five Departments: Governor's office, Office of the Chief of staff, Political and Legislative Powers Bureau, Ministry of Special duties and Intergovernmental Relations, and Liaison office. Instead of one Permanent Secretary, there are now five Permanent Secretaries and five Directors of Finance and Administration. For purely political consideration, there are now five persons performing the job one person did in the past. There is therefore widespread overlapping of functions that lead inevitably to power 
struggles. The Office of the Chief of Staff and the Political and Legislative Powers Bureau are both in charge of political intelligence and political correspondence. With the overlap in functions, many of the staff members are under-utilised; they evade responsibilities, and commonly abandon their duty posts because there are no clearly defined assignments, leaving them with time to engage in moonlighting and private agenda.

PSSIII commented, "The Lagos State Government started from the old secretariat with 7 Permanent Secretaries. The Ministries and Agencies are now 43. The Service has grown in terms of staff population. A lot of expansion and restructuring of the government are still going on. The Pensions Department has recently been moved from the Ministry of Establishment and Training to the Ministry of Economic Planning and Budget."

One other recommendation was to revert the position of Director-General to Permanent Secretary with the additional responsibility of being the accounting officer. The appointee must be a senior career civil servant. Based on the 1988 reform, failing re-appointment, many experienced officers had been lost as Directors-General left along with the administration that appointed them. After the 1997 White Paper, the selection of Permanent Secretaries by GVM11 was mainly based on seniority and merit. After 1999, during the civilian dispensation, several officers complained that seniority and merit did not come into play for the selections of some Permanent Secretaries, as some of nominations were politically motivated. Example include the appointment of the Permanent Secretary ${ }^{121}$, Ministry of Health, and the nomination of the Executive Secretary, Land Use allocation Committee as the Permanent Secretary, Lands.

Defending this action, however, GVC12 said,

"I disagree that I am trying to politicise the system. I can count on my Permanent Secretary for Health. He is experienced and he has made a lot of changes in the public health care. He has altered the health care system. With the Land Use, the whole system was collapsing. The land registry was not up to par. I gave them 3 years to change but they refused to change. I also brought a Director (to head the Computer Department). The political appointees were so minor. We needed a blend. For some of the appointments I would have politicised the system if I have brought them from inside."

However, many informants and respondents believe that the politicisation is negatively influencing the civil service. The three examples given by the Governors are doing well, thereby supporting the belief of the researcher that there are people outside the civil service whose skills and experience can benefit the Service. However, problems come when appointments are made due to political pressure and the people come into the service through improper hire. When established rules concerning recruitments are not followed, it leads to lack of trust and frustrations on the part of the existing officers. There are many square pegs in round holes.

PSSIII said, "The mass recruitment that was conducted was to satisfy people from different local governments. People were told to submit names for employment and many people that were not qualified were employed. A graduate of insurance has no business to be in government service. These would lead to poor quality in service. Politically the leaders wanted to satisfy the people and this is leading to unwarranted expansion to the civil service. The service is not reaping any benefit from this expansion."

Another of the recommendations was that the restoration of the position of the HOS. The HOS would be appointed from the rank of Permanent Secretaries or officers of equivalent posts, while the SSG will be a political post appointed at the discretion of the President or the Governor. According to GVM11,

${ }^{121}$ He was appointed from outside the Civil service. 
"The Lagos State Government was the first in the federation to split the position of the Head of Service and the Secretary to the State Government. This was very fundamental."

However, the establishment of the positions of the Head of Service and Secretary to the State brings confusion, because of the thin line in some of their "responsibilities of assignments".

During the Third Republic, GVC12 compounded this problem by the establishment of the Office of Chief of Staff. Having these three positions simultaneously undermines the position of the Head of Service. According to their responsibilities of assignments, only the HOS is in charge of staff postings. However, in 2005, HOS14 did some staff postings, and a few days after, a circular from the Office of the Secretary to the State Government reverted the postings. Whom do the staff obey? To whom are the staff in the Governor's office accountable, the HOS or the Chief of Staff who is a political appointee?

Studies show (Polidano, 2001; McCourt, 1999; Therkilsen, 2001; Olowu, 2000) that among the many organizational factors, the reform's human resources management strategies had the most adverse effect on the evolution of the civil service. The key elements include downsizing, which affected many experienced staff whose education and training could enhance management; the retrenchment also led to low morale of staff; inflation's nullification of monetary incentives to staff led to poor performance in service delivery. Another contradiction in the reform is that in Lagos State as the government retrenched, it hired at the same time. This action of the government made staff doubt the government's sincerity in its bid to right size the civil service ${ }^{122}$.

Concurring, PSSI remarked that, "Since there was no longer security of tenure of office, the loyalty of the staff that remained was greatly affected. Before, permanent appointments were regularized and confirmed by rules. When a misdemeanour was committed, there were rules by which the culprit was punished. These are no longer there. People are dismissed indiscriminately." According to RSSG, however, "The purge was introduced to bring some sanity. Since it was a pensionable service and many higher civil servants felt that they could not be dismissed. The Federal Civil Service was becoming very patrimonial and they were trying to entrench themselves in the system. There was decadence. This had to be stopped especially in the Federal Civil Service that was becoming very tribalistic. However, this exercise instead of achieving what it was meant for turns into witch-hunting."

PSSIII reflected, "One of the Government's policies that negatively affected the civil service is the reforms. The security of tenure that was cherished was destroyed by the mass retirement. This affected many good officers. This policy is being perpetuated by subsequent administrations both military and civilian. It has a lot of negative effect as good staff are removed and are being replaced by inexperienced officers. The quality of service declined."

To fill the senior-level vacancies, many people were hired from outside the service and some insiders were put in posts for which they were not suitable. Instead of containing the expansion, the Ministerial restructuring in Lagos State Government has led to duplication and overlapping of responsibilities of assignments; a situation that leads to ineffective implementation of government's policies.

${ }^{122}$ This issue has been discussed extensively in chapter 5 under recruitment. 


\section{Conclusions and Recommendation}

This study examined the nexus of governance and bureaucracy in the context of a country in sub-Saharan Africa. It examined the nature and role of civilian and military leadership over a period of about four decades in Lagos State, Nigeria. In this concluding chapter we provide an overview of the impact of political and administrative leadership on the performance of the civil service's institutional capacity.

The study was based on the following research questions:

1. "To what extent have different forms of political leadership represented by authoritarian/military and democratic/civilian governance influenced public policy in Lagos State, Nigeria?"

2. "How has the political leadership's influence on the administrative leadership impacted the performance of the civil service?"

3. "Does the State Government have the institutional capacity for effective civil service performance?"

4. "Have the recent reforms of the civil service impacted negatively or positively on performance?"

The research studied the civil service as a system with actors in an institutional environment that evolved within a historical context that helped shape it, interacting with each other at the state and the federal levels. In order to translate the research questions into an achievable empirical study the research employed a multi-level case study design. This helped to give an indepth knowledge to the changes that occurred in the performance of the Lagos State Civil Service from its inception in 1967 to 2005 . The researcher employed a variety of instruments and used both qualitative and quantitative methods. The mix of approaches was necessary to capture the historical influences that were difficult to obtain from official documents alone. The study administered questionnaires and conducted series of interviews and informal group discussions. The structured interviews were mainly with the major actors, the present and past civilian and military Governors and with other informants. Content of the interviews are attached as appendices I and II respectively. There was also the administration of questionnaires to civil servants, attached as appendix III. The group discussions helped to confirm the results of the interviews and analysis of the documents. The quantitative data were analyzed in order to test the statistical relationship between the dependent variable (performance of the civil service) and independent variable (leadership qualities). Secondary data was collected and quantitatively analyzed with descriptive statistics. These methods together helped to give the research some rigour and increased its robustness.

\subsection{Leadership and Public Service Performance}

In developing countries especially those in Africa, political leaders may either use their power to promote policies that could advance social and economic development or foster their personal agenda to the detriment of the larger society (Olowu and Sako, 2002). Ideally, the duty of political leaders is to harness and ensure that the capacities and capabilities of institutions are properly harnessed in order for them to function properly. The overall performance of governments depends on the influence of political leadership on the governance system. 
Regime types influence leadership traits; for instance, a military regime will have the propensity to produce an authoritarian leader, while a civilian regime will most likely have a democratic leader that will be responsive to the needs of its population. This study has shown however, that such a neat categorization while useful as a theoretical construct does not hold true in reality in the case of Lagos State. Comparisons from India, Korea and Singapore neither support such a simple categorization. India as one of the oldest democratic nations in the advanced developing country has experienced relatively slow socio-economic growth partly as a result of some poor public policies; on the other hand, Korea and Singapore undertook significant economic reforms as essentially one-party states (Mesquita et al., 2000).

Nigeria as an independent state has gone through 32 years of military rule out of its 45 years of existence. Some of its characteristics are: high state capture, non-participatory governance and authoritarian leadership. The present research shows that in Lagos State some authoritarian regimes performed relatively well, with fairly responsive governments. On the other hand, some elected political leaders have been impervious to the demands from the electorate. This, in spite of the fact that authoritarian leaders did not have to satisfy an electorate through popular redistributive public policies, because their votes did not put them into power.

The study therefore concludes that democracy has not necessarily fostered state responsiveness while some authoritarian governments surprise with populist policies. The success of each regime, be it military or civilian, rather appears to depend on the following:

- Leadership competence on decision-making and problem solving;

- Institutional continuity; and

- Policy legitimization and accountability.

\section{Leadership Competence in Decision-Making and Problem Solving}

Absence of sanguine political leaders, legitimate rule and institutional capacity for the development of problem solving mechanism, have been identified as some of the major problems in Africa (Adamolekun, 1986; Wunsch \& Olowu, 1990). The research reveals that leadership competence in decision-making and problem solving is one of the key factors that determine the success of governance and the performance of the public service. This is evident in both civilian and military regimes. Although military regimes do not have democratic legitimacy, the ability of a military leader to perform relatively better than a democratic one tends to be closely related to personal qualities. Additionally it depends on the governance capability of the bureaucracy advising the leader (Fukuyama, 2004).

Successful leaders are open and participatory in their approach to decision-making and problem solving and are committed to state building. There are elements of transparency and accountability in their governance and the staff and the citizenry have confidence in them. These leaders have a realistic assessment of the institutional capacity of the civil service and they make use of it optimally. When these political leaders are novice in the art of governance, they rely on the experience of the bureaucracy.

On the other hand, the root of ineffective decision-making and problem solving can be linked to the lack of preparation of Chief Executives to deal with the complex political problems they are confronted with. Many do not get to their position through effective leadership training, or demonstrable administrative competence. To legitimise themselves their decisionmaking becomes associated with patrimonialism, incompetence and opportunism. This tarnishes them as leaders and undermines their performance.

Successful political leadership must have policy guidelines, and ensure that administrators implement them effectively. The leader is supposed to be transparent and open with a focus on public policies for the common good of the people. This could ultimately lead to im- 
proved economic performance and poverty reduction. However, most leaders, due to continuous political instability, did not institutionalize systems for decision-making and problem solving. Consequently, the crucial institutions that are supposed to carry out specific functions of governance are still weak or non-existent.

\section{Institutional Continuity}

Military regimes in Nigeria were removed from office through coups d'état, and twice through voluntary surrendering of power; situations that led to constant changes of Chief Executives in Lagos State. These, in turn, led to lack of institutional continuity and episodic policies. Also, some of the civilian regimes did not develop strong political bases and demonstrable accountability through performance and responsiveness to the issue of governance. Political instability has adversely affected the development of institutions to implement effective policies.

The research shows that the abrupt changes of Chief Executives undermine policy sustainability and consistency in government policies. Each government comes up with different policies that do not necessarily support that of the predecessor. Lack of sustainability bred poor accountability leading to pervasive financial mismanagement and misplacement of priorities.

\section{Policy Legitimization and Accountability}

In Nigeria the military operated without checks and balances from the Legislature. The Legislature is supposed to authorize and monitor the state's expenditure to curtail inefficiency and waste through transparent implementation of policies and programmes. Ruling without these kinds of checks and balances provided by the Legislature has led to a lack of accountability, cronyism and corruption. The Judiciary being constrained by lack of financial autonomy and of a supportive constitution, further compounded the situation. The press, though vibrant, has been scuttled by the system. The law enforcement agency became corrupt.

Civilian rule operated with an ineffective Legislature, lacking institutional capacity to effect compliance by the Executive in cases of misdemeanours. Ultimately, the ability of any leader to perform may not be due to any political philosophy. The research rather finds that some regimes lack policy legitimization and accountability because there is no effective institution or supervisory body that has the capacity to act as a watchdog on behalf of the populace and ensure that the Executive is accountable in the areas of administration, finance and appointments.

The absence of good performance of state and non-state institutional capacities to evaluate and monitor policies and programmes affect the development of effective policy processes that influence good governance. The political leadership and higher echelon of the civil service continue to be the main institutions in charge of policy. The political structure is monocentric with the state being the locus of power and the center of problem solving (Ostrom, 1997). Political leadership may lack capacity because of political instability. The higher civil service that is supposed to be well motivated, efficient and neutral is demoralized by incessant politicization and wage erosion. Eventually, this main instrument of governance does not follow the due process in the execution of policies and programmes. This leads to corruption and inefficiency in the performance of public service delivery, and ultimately, lack of accountability. The importance of transparency and accountability cannot be underestimated because they are the cornerstones of socio-economic and political development of any nation. According to one of the past Governors,

"where there is a leadership that is industrious knowledgeable, determined, purposeful and missionary there is no room for poor performance or unprofessional conducts by 
the civil servants. What the civil service needs is a clear sense of direction. Transparency and accountability in the public sector are the hall marks of good government".

\subsection{Institutional Capacity and Public Service Performance}

Three factors influenced the governance and the bureaucratic set up of the Lagos State Civil Service, and subsequently affected its performance:

- Human Resource Management

- Finance and Economic Policies

- Organizational Structure

\section{Human Resource Management}

One of the main features of human resource management in any organization is to ensure that the knowledge and skills of workers and managers are effectively utilized to achieve stated goals. This is the ability to employ and keep quality staff through sufficient motivation and the design and implementation of appropriate training policies for the improvement of staff. The pertinent factors in the bureaucracy proposed by Weber for effective performance of the public service are that recruitment, employment, and promotions be based on qualifications and achievement, internal labour markets and professionalization. The system should be impartial, permit no favouritism, or nepotism, and promote unbiased decision-making. The emphasis should be on a career pattern without arbitrary termination of appointment.

Olowu (1999) suggests that 'non-core' elements in human resource management of the public service greatly influence the performance of this sector. These include a well-organized merit system, strong system of accountability, decentralization of operations and structures, capacity of policy-making institutions, political responsiveness of top civil servant and capacity building. These in collaboration with other "core" elements like organizational restructuring and budgetary and financial reforms help to build a viable public service.

The research found that one of the major factors that affected the institutional capacity and the performance of the public service are human resource management policies adopted by the government. The government deviated from meritocracy when it introduced policies like the one with "federal character" 123 (representing ethnic formations). In Lagos State this was seen through the efforts to bring in indigenes in order to have "adequate" representation in government. This exerted a negative influence on human resource management policies in the bureaucracy. Under this type of policy some people were placed into positions of authority, which they were ill equipped for. These individuals were put in charge of policy formulation and implementation, and lack of experience tends to lead to poor decisions, indiscipline in governance, rampant corruption, and nepotism.

Another prominent factor identified is the politicisation of the public service. Political neutrality, a sine qua non for effective bureaucracy was lost. Salisu (2000) also opined that political leaders' interference in the civil service made public servants lose confidence in the system. Some military leaders had slight regard for bureaucrats' advice and often ignored procedural rules and regulations. The civilians on the other hand, did not believe that the bureaucracy should be entrusted with authority. This is reflected in human resource management policies like the abandonment of meritocracy; the system became characterised by lack of neutrality and impartiality in the recruitment, promotion, discipline and dismissal of the civil

\footnotetext{
${ }^{123}$ Federal character is supposed to give a chance to the "weak" in federalism as an index of balancing in order not to marginalize some members of the federal State. If properly implemented, it can help in the establishment of good and smooth governance.
} 
servants. Recruitment is then no longer based on an open competition regardless of sex, religion or class.

Our respondents rated the following factors as adversely affecting the quality, effectiveness and efficiency of the civil service:

- Recruitment and promotion not based on merit;

- Salary and remuneration not adequate;

- Loss of confidence in the system due to retrenchment;

- Fear of early retirement led to illegal acquisition of government's properties;

- Training and retraining not mandatory or relevant.

\section{Finance and Economic Policies}

Federal Government's macroeconomic policies adversely affected the state government's performance. In Nigeria especially under military regimes, there was low state autonomy. States depended heavily on federal allocations for the implementation of their public service programmes because many states were economically weak; some were created on political considerations rather than economic viability. Resources were not justifiably shared and infrastructural developments were sometimes based on solidarity or ethnic affiliations. Irregularities in budgetary allocation negatively affected the planning process of these states. However, the states needed sufficient financial resources to provide a reasonable level of public service. But a significant disparity occurred between the monetary allocation and the public service delivery mandates given to states and local governments (Olowu, 1990).

Another factor that severely impacted the performance of the public service was the Structural Adjustment Programme that led to fiscal and budgetary restrictions. The Nigerian Government was seen as "big" and "wasteful and inefficient in economic management" (Essien 1990). The Federal Government was subsequently influenced by the World Bank to cut back its role in economic activities and also rationalize the public service to make it more affordable and reduce government expenditure. This "cutback strategy" would make government leaner and the administration would focus on "core activities". This would lead to a balance between expenditure of the public Sector and its resource base. The money saved, would be used to pay the remaining civil servant decent salaries. This has not proven feasible.

The insistence of the Structural Adjustment Programme on currency devaluation and the removal of petroleum subsidies led to some unforeseen consequences in performance of government. The associated devaluation of the Naira had the following impact on the public servants:

- Galloping inflation adversely affected the salaries and remunerations of staff;

- Sharp decline in the purchasing power of workers;

- Wage freeze;

- Wage erosion and compression

Public servants therefore engaged in other economic activities to sustain themselves and their families. An increase occurred in absenteeism and late-coming. Both junior and senior staff engaged in moonlighting. There were demonstrations by public servants for salary reviews. Commitment to organizational goals in the public service sank to zero level.

Furthermore, Lagos State was at the same time experiencing rapid urban growth. The existing public service apparatus became inadequate, leading to unreliable infrastructure, unemployment, and slum growth. Political leaders had to mobilize internal and external resources for public service delivery and at the same time meet government recurrent expenditure target. The government battled with competing demands for salaries and provision of public service. Problems with revenue collection and the absence of an adequate taxation 
strategy for companies and wealthy citizens weakened taxation as one of the main revenue streams. Furthermore, the state became deeply caught up in public service deliveries to the detriments of feasible economic projects; all these put great pressure on government finance.

\section{Organizational Structure}

The institutional capacity of government has been greatly undermined in terms of its organizational structure and this has affected the performance of the civil service. The World Bank posits that the size of government is too large, especially in sub -Saharan Africa. In Nigeria there is usually more restructuring of the state government during civilian regimes than under the military. Civilian leaders regard government as their "personal fiefdom" and use their positions to compensate supporters and financiers with political appointments. Recruitment into politically motivated positions does not follow any manpower development strategy. This leads to overlap of functions, as job descriptions are no longer based on function requirements. This leads to the government becoming inefficient and bloated.

By giving political consideration to appointments, most government appointments are no longer based on competence and this leads to disruption; Ministries are frequently renamed and restructured. Organizational functions are thus fluid and personalized. These episodic changes lead to enormous waste even in the daily functioning of the State. For instance stationeries have to be changed to reflect the new names of the agencies and new furniture acquired. The buildings have to be redesigned and repartitioned to make room for the new Departments being created because recruitment is carried out without adequate consideration for physical infrastructure. Civil servants are gradually being marginalized and have to rely on inadequate resources to do their work. Aside from financial waste, there are usually overlaps of Ministerial responsibilities. This often leads to tension, conflicting loyalty and lack of trust between the senior civil servants and political appointees. Such a hostile working environment inhibits government performance.

\subsection{Public Policy and Public Service Performance}

According to Walt (1994), the nature of a political regime will determine the sort of policies that will be pursued. Liberal democracies usually encourage participatory governance, while authoritarian regimes support non-participatory governance. The research has shown in Nigeria however, during both military and civilian regimes, there has been high state capture and non-participatory governance. Non-state institutional capacity is non-existent due to lack of resources, experience, and legitimacy and for this reason; civil society is unable to provide a credible voice to be sufficiently reckoned with in public policy. Therefore the force of a strong and credible civil society voice that could induce state commitment to state policy objectives, transparency and accountability through public pressure, has been minimal.

Ellis (1996) notes that the factors that affect policy making in developing countries include charismatic leadership, ethnicity and tribalism, dominance of ruling elites, great scarcity of resources and backwardness. The pattern and relative influence of policy-making is therefore not based on the particular policy of any regime (military or civilian) but on personal qualities of the political leaders and their ability to cooperate with the bureaucracy for policy implementation. The research shows that the following factors adversely affect public policy in Nigeria:

- Discontinuous political institutions;

- Declining institutional capacity of government;

- Patrimonial disposition of the state. 


\section{Political Institutions}

Policymaking is fundamentally a process whereby institutions with different concerns try to maintain and enlarge their power base. In Nigeria the military has severely undermined the competence, capacity and confidence of political parties. For instance, at the times when the military was forced to disengage they invited the parties (usually dominated by ex- military leaders) to regroup under a superficial political umbrella lacking a coherent philosophy and legitimacy. This blatant political manipulation tended to erode political administrative capability and capacity that is ordinarily an outcome of sustained learning and maturation. The ability to make good public policies was lost in the process because of the weak institutional capacities of political parties. The political institutions are therefore fragile, and the resulting civilian government is in a constant state of flux. Ultimately, the political parties do not have a coherent political philosophy and they end up with policies that reflect private rather than public interests (Olowu 2002) and public service performance is adversely affected in the process.

\section{Institutional Capacity of Government}

In view of the instability that characterizes the polity, the institutional capacity of government in policymaking is equally built on a weak foundation. Bureaucratic structures are maintained through strong patron-client relationships and not through the competence and neutrality of civil servants (Elbassi 2003). This eventually leads to what Fukuyama (2004) refers to as the frail capacity of the state and its inability to plan and execute policies and to transparently enforce the laws. This incapacitates the state to effectively formulate and implement good policies and this leads to poor performance of the public service.

\section{Patrimonial Disposition of the State}

Another factor that adversely influences good public policies is the patrimonial tendency of the state whereby persons and individual interests are placed above institutional rules. A good public policy is evinced by responsiveness to the majority of the populace, if not the totality of the citizenry (Olowu 2002). The formulation and implementation of such policies must be seen as transparent and open. A public policy that is influenced by patrimony is what Evans (1995) refers to as predatory behaviour. The state or the bureaucracy is characterized by personalism. Patrimonial disposition of the state harmfully affects elements of good public policies that could have helped to establish good governance.

According to the Chair of the Technical Committee for Privatization and Commercialization (TCPC) in 1988, this leads to misuse of monopoly of powers, mismanagement, corruption and nepotism. In Lagos State, seemingly good programmes like the Jubilee Housing and Mass Transit Schemes were ill conceived and badly implemented because they were given to inept officials to handle. Private sector participation in contracting services such as garbage collection was not successful because many operators were party faithfuls or had "connections" with the administration. So the government lacked the political will to enforce compliance in case they defaulted in their operations. A patrimonial disposition of the state harmfully affected public policies that could establish good governance.

\subsection{Civil Service Reforms and Public Service Performance}

The final issue this research looked into was the influence of Civil Service Reforms on the governance and the bureaucratic set-up of the Nigerian Civil Service. The Nigerian Civil Ser- 
vice needed reform to improve its performance and promote transparency and accountability. Nigeria started experiencing stagnation in its economic growth and a decline in the standard of living. Slow economic growth is symptomatic of deeper fundamental structural problems that relate to institutions, political pluralism, participatory democracy and human rights.

The bureaucratic reforms that took place in Nigeria were externally influenced; some were home-grown. The essence was to return professionalism, accountability and transparency to the civil service. The reforms emphasized such issues as restructuring of the civil service, introduction of performance-productivity related pay, review of performance appraisal of staff, re-evaluation of the information management system, improvement in record keeping, professionalization, and training.

The current research finds that the restructuring exercise had major adverse effects on the civil service. Retrenchment led to disruption in the career pattern of civil servants and loss of essential capacity. Fear of early retirement drove many senior civil servants into partisan politics. The Ministerial restructuring in Lagos State also expanded the government, leading to duplication of responsibilities. Vacant top positions were given to people hired from outside and insiders were put into posts some were not qualified for. The reforms led to the politicisation of the service and gradual erosion of the old public service ethos of meritocracy. Instead of enhancing the performance of the civil service the reform led to more ineffective formulation, coordination and implementation of government's policies.

\subsection{Recommendations}

Political misrule and power misuse in Africa, plus the associated bad governance have resulted in low socio-political and economic development, high levels of poverty and corruption (Olowu, 2002). Political and administrative leaders have not been accountable to their citizens. The Canada Royal Commission (1972:21) defines accountability as "the fundamental prerequisite for preventing the abuse of delegated power and ensuring instead that power is directed toward the achievement of broadly accepted national goals with the greatest possible degree of efficiency, effectiveness, probity, and prudence".

This research has shown that accountability as based on this definition, is missing in the governance, bureaucratic set-up, and the relationship between the political-administrative leadership and the citizen in Lagos State, Nigeria. However, Nigeria has the potentials of becoming a leading economy in Africa in view of its human and natural resources. To attain this position it needs to raise transformational leaders, promote committed citizenry and build sustainable and effective institutional capacities by adopting some of the following recommendations.

\section{Develop Strong Legal State Institutions}

Making public officials and Ministries accountable to the public for the way they carry out their legally assigned duties, makes for good internal checks and balances. This will discourage patrimony and induce respect for meritocracy. Political leaders and government officials should be given instant and open penalty through the judicial process, if they appropriate public property for personal use, or promote sectional interests to the detriment of the achievements of the state in particular and the country in general. The severity of the penalty should be sufficiently high to be a disincentive to such behaviour.

To achieve this objective, the Judiciary needs to be strengthened through well-resourced capacity development and the design and implementation of good remuneration for judicial officers. This process will shield them from the temptations to be corrupted. The judicial system needs to undergo modernization to best serve the citizenry. 


\section{Develop Viable Political Institutions}

The incessant incursion of the military into politics in Nigeria led to the emergence of leaders who are not accountable to the populace, a behaviour that civilian leaders emulate. The paradigm shift from autocracy to democracy is a political process that needs the commitment of the citizenry. There is a need for the civilian political leaders to be more transparent and show greater responsiveness to public needs. The less parochial and predatory the civilian political leaders are, the less the tendency for military opportunism. Meanwhile, stability in the political process will lead to the political leadership developing competence in decision-making and problem solving. Political stability will foster institutional continuity and lasting legitimate policies that will ultimately lead to accountability and transparency in governance.

\section{Build Capacity for State and Nonstate Institutions}

The governance structure should move away from being "monocentric" with the state being the locus of power and the center of problem solving, to collective participation by other nonstate institutions for the common good of society. The knowledge base for governance should not only be with the government, although the need for a competent and developmental state is evident in this study. Other actors like researchers, civil society groups, and political parties should be involved in the policy process for the solution of social problems.

Involvement of these non-state institutions in societal policy issues would help the state to develop from the community level upward (Wunsch \& Olowu, 1990) as they are able to bring their knowledge into the formulation and implementation of public policies. Direct citizens' participation and appraisal will help government organizations to improve service deliveries. For the state institutions, there is need to develop and modernise the public policy processes of the Executive, Judiciary and Legislature. There must be transparency, openness and accountability in both the state and non-state institutions.

\section{Promote Meritocratic Bureaucracy}

The civil service must be competent, effective and efficient in order to be able to implement government policies. In order to eliminate inefficiency and corruption in the government the institutional capacity of the bureaucracy must be developed. This is possible through the reintroduction of a well-organized merit system and a strong system of accountability. The human resource management policy should be impartial, and must not permit nepotism or patrimony. There should be no arbitrary appointment or termination without recourse to the appropriate rules. Furthermore, there must be minimal political leaders' interference in the day-to-day working of the public service. There is need for public servants to regain confidence and trust in the system.

Any new reform must adopt a results-oriented approach, by drawing experience from earlier imported and home-grown reforms in terms of successes and failures. Subsequently, the political, administrative and civil society leadership must be committed to reforms and the contents of such reforms.

These recommendations have been proffered on how to improve the performance of the public service. But all the recommendations cannot be achieved without explicit support of the political leaders. There must be a rethinking on the parts of the political leaders that the path to socio-economic and political development is not through ethnicity or nepotism, but through improved governance and effective state capacity. 


\section{References}

Adamolekun, L. 1988. "Political Leadership in Sub-Saharan Africa: From Giants to Dwarfs" International Political Science Review 9 (2), 95-106

Adamolekun, L. 1998. Politics and Administration in Nigeria. London: Hutchinson, and Ibadan: Spectrum Books.

Adamolekun, L. 2002. Public Administration in Africa: Main Issues and Selected Countries Studies. Ibadan: Spectrum Books limited

Addison, T. 2003. "Do donors matter for institutional reform in Africa?" in Reforming Africa's Institutions: Ownership, Incentives, and Capacities. Kayizzi-Mugerwa, S. ed. United Nations University Press, U.S.A.

Adebayo, A. 2001. Principles and Practice of Public administration in Nigeria. Spectrum Books Ltd. Ibadan, Nigeria

African Development Bank. 2001. African Development Report 2001. Oxford: Oxford University Press

Ajakaiye, D.O and Akande, S.O. 1999. A Characterisation of Industrial Demand for Major Agricultural Commodities in Nigeria. A publication of the Socio-Economic Policy Research, 1999.

Ake, C. 2001. Democracy and Development in Africa. Spectrum Books Ltd. Ibadan.

Almond, G. and Coleman, J.S. eds. 1960. The Politics of the Developing Areas. Princeton: Princeton University Press.

Anderson, J. 1975. Public Policy making. London: Nelson

Appleby, P. (1949) Policy and Administration, Alabama, University of Aabama Press.

Avolio, B. and Bass, B. 1999. "Re-examining the components of Transformational and Transactional Leadership using the Multi-factor leadership Questionnaire" Journal of Occupational and Organizational Psychology 72 (Dec.): 441-463.

Awortwi, N. 2002. "Managing Multiple Modalities of Delivering Basic Services in Ghanaian Cities" in Africa Development Vol. Xxvii, nos. 3\&4, ed. Dele Olowu.

Ayeni, V. 1992 "Further Developments and the Future" pp153-167, Victor Ayeni (ed) Civil service transformation for structural adjustment. Nigerian Institute of Management.

Balogun, M.J. 2002. "The democratisation and Development Agenda and the African Civil service: Issues Resolved or Matters arising”. International Review of Administrative Sciences. Vol. 68, No. 4

Balogun, M.J. 2003. "The Performance Management and Agency Governance for African Development: The Search for Common Cause on Excellence in the Public service. Addis Ababa: United Nations Economic Commission for Africa.

Barzelay, M. 1992. Breaking Through Bureaucracy. Berkeley: University of California Press.

Bass, B.M., 1990. Bass and Stogdills Handbook of leadership. The free Press.

Bayart, J.; Ellis, S. and Hibou, B 1999: La criminalisation de 1Etat en Afrique. Paris, 1997, Editions Complexe The Criminalisation of the State in Africa, Oxford: James Curry. 
Boston, J. 2000. “The Challenge of Evaluating Systemic Change: The Case of Public Management Reform” Paper prepared for the IPMN Conference "Learning From Experiences with New Public Management", Macquarie Graduate School of Management, 4-6 March, Sydney.

Bratton, M. and Mattes, R. 2001. “Africans’ Surprising Universalism.” Journal of Democracy 12 (1): 107-121

Caiden, G. 1969. Administrative reform. Aldine Publishing Company, Chicago.

Chang, H. 2002. Kicking Away the Ladder- Development Strategy in Historical Perspective. London: Anthem Press.

Corkery, J., Daddah T. O., O’Nuallain C., Land, T. (eds) 1998 "Management of Public Reform: A comparative Review of Experience in the Management of Programmes of Reforms of the Administrative Arm of Central Government" IOS Press, Amsterdam.

Danielson, A. 2003 "Economic and institutional reforms in French-speaking West Africa: Impact on efficiency and growth" in Reforming Africa's Institutions: Ownership, Incentives, and Capacities. Kayizzi-Mugerwa, S. ed. United Nations University Press, U.S.A.

Davis, G., Sullivan, G.B., \& Yeatman, A. (eds) 1997. The New Contractualism. Melbourne: Macmillan.

Dike, V.E (2005). "Corruption in Nigeria: A new Paradigm for Effective Control” in www.AfricaEconomicAnalysis.org

Dobbs, C. and Field, M.W. 1993. “Leaders Vs. Managers”. FBI Law Enforcement Bulletin 62 (Aug.): 22-26.

Dunleavy, P. and Hood, C. 1994, "From old public administration to new public management", Public Money and Management, July-September.

Durevall, D. 2003. "Reforms of the Malawian public sector: Incentives, governance and accountability" in Reforming Africa's Institutions: Ownership, Incentives, and Capacities. Kayizzi-Mugerwa, S. ed. United Nations University Press, U.S.A.

Dwivedi, O. P. 2002. "On Common Good and Good Governance: An Alternative Approach" pp.34-54 in Better Governance and Public Policy, Olowu, D. and Sako, S. ed. Kumarian Press, Bloomfield, U.S.A.

Easton, D. 1965. A Framework for Political Analysis. Englewood Cliffs, N.J.: Prentice Hall

Edquist, C. 1997.System of Innovation Technologies, Institutions and Organizations. London and Washington: W.W. Norton.

Elabassi, M.A.Y. 2003. Public Health Sector Reform: The implementation of federal decentralisation in Sudan and its impact upon the sector of public health. Datawyse Universitaire Pers Maastricht

Elazar, Daniel J. ,1987, Federalism As Grand Design: Political Philosophers and the Federal Principle. Lanham, MD: University Press of America.

Ellis, S. 1996. “Africa now: people, policies \& institutions.” The Hague: Ministry of Foreign Affairs.

Essien, E., Nigeria under Structural Adjustment. Fountain Publications, Ibadan, Nigeria, 1990.

Evans, P. 1989. "Predatory, Developmental, and other Apparatuses: A Comparative analysis of the Third World State," Sociological Forum 4(4): 561-82.

Evans, P. 1995. Embedded Autonomy: States \& Industrial Transformation. Princeton University Press, Princeton, New Jersey.

Ferlie, E.L., Ashburner, I., Fitzgerald, L. and Pettigrew, A., 1996, The New Public Management in Action, Oxford: Oxford University Press. 
Fukuyama, F. 2004. State-building: Governance and World Order in the Twenty-First Century. Profile Books Ltd. London.

Gendron, Y., Cooper, D.J., et al. 1999. "In the name of Accountability: State Auditing in

Ghauri, P., Grфnhaug, K., Kristianslund, I. 1995. "Research Methods in Business Studies- A practical guide" Prentice Hall.

Gijsbers, G. 2001. “Governance and institutional innovation” Discussion Paper, International Service for National Agricultural Research.

Girishankar, N. 2000 ‘Approaches to Sequencing Public Sector Reform’, Unpublished World Bank paper, Washington DC, as cited in Nick Manning 1998 'Legacy of NPM in developing countries' in International Review of Administrative Sciences 67(2).

Global Network 2002. http//www.Megacitiesproject.org/network/Lagos. Asp

Gopal, J. (2001). The Development of Malaysia's Palm Oil Refining Industry: Obstacles, Policy and Performance. $\mathrm{PhD}$ Thesis submitted to Imperial College, London

Goode, R. "An Overview of Experience - Obstacles to Tax Reform in Developing Countries," in Bird and Oldman, Taxation in Developing Countries, 4th Ed. Johns Hopkins University Press, 1990.

Goodin, R, 1996, "Designing constitutions: the political constitution of a mixed commonwealth". Political Studies 44: 635-46.

Goldsmith, A.A. 2001. Institutions and Economic Growth in Africa pp 24-51 in Restarting and Sustaining Growth and Development in Africa. Edited by M.F McPherson. http://www.eagerproject.com/rsg.shtml

Gray, C. and McPherson, M. 2001. The leadership Factor in African Policy Reform and Growth pp.134-156 in Restarting and Sustaining Growth and Development in Africa. Edited by M.F McPherson. http://www.eagerproject.com/rsg.shtml

Grindle, M.S. (ed) 1981. "Politics and Policy Implementation in the Third World" Princeton: Princeton University Press

Grindle, M. and Thomas, J.W. 1991. Public Choices and Policy Change: The Political Economy of Reform in Developing Countries. Baltimore and London. The John Hopkins University Press

Gummesson, E. 2000. “Qualitative Methods in Management Research” 2nd Ed. Sage Publications, Inc.

Halligan, J., 2001. "Comparing Public Sector Reform in OECD”, in B. Nolan, ed., Public Sector Reform: An International Perspective, Hampshire: Macmillan

Hamdok, A. 2003. "Governance and policy in Africa: Recent experiences” in Reforming Africa's Institutions: Ownership, Incentives, and Capacities. Kayizzi-Mugerwa, S. ed. United Nations University Press, U.S.A.

Heckscher, C. 1994. “Defining the Post-Bureaucratic Type”. In Charles Heckscher and Anne Donnelon, Eds. The Post-Bureaucratic Organization. Thousand Oaks, CA: Sage

Hersey, P. and Blanchard, K. H. 1993. Management of Organizational Behavior: utilizing Human Resources. 6th edition. Prentice-Hall, Inc., Engle cliffs, New Jersey

Hood, C. S. 1991 “A Public Management for All Seasons”: Public Administration 69 (Spring); pp. 3-19

Hood, C. 1995 The 'New Public Management' in the 1980s: Variation on a Theme', Accounting, Organizations and Society 20(2/3): pp. 93-109.

House, R.J. and Aditya, R. N. 1997. “The Social Scientific Study of Leadership: Quo Vadis?” Journal of Management 23 (Special Issue): 409-74 
Hughes, O. 1998. Public Management and Administration. London: Macmillan

Hyden, G.D. 1986. “The Anomaly of the Africa Peasantry” Development and Change, 17 (4), pp. 677-705

Hyden, G.D., and Bratton, M. eds. 1992. Governance and African Politics. Boulder, Colo.: Lynne Rienner Publishers.

Hyden, G.D., and Court J., 2002. "Comparing Governance Across Countries and Over Time: Conceptual Challenges" pp. 13-34 in Better Governance and Public Policy, Olowu, D. and Sako, S. ed. Kumarian Press, Bloomfield, U.S.A.

Idris, I. (2003). “The Contradiction Called Mahathir". www.pakistanlink.com

Isaac-Harry, K., Painter, C. and Barnes, C. Ed, Management in the Public Sector: Challenge and Change. ITP 1997

Jaffee, D. 2001. Organizational Theory, Tension and Change. Singapore McGraw-Hill International Editions.

Jones, L. R. and Thompson, F. 1999 Public Management: Institutional Renewal for the Twenty-First Century. Stanford, CT: JAI Press.

Joseph, R. 1987. Democracy and Prebendal Politics in Nigeria: The Rise and Fall of the Second Republic. Cambridge: University Press, Cambridge, England.

Kanza, T. 1971. Unpublished memoirs, quoted in The Demigods by Jean Lacouture London: Secker \& Warburg.

Kayizzi-Mugerwa, S. ed. 2003. Reforming Africa's Institutions: Ownership, Incentives, and Capacities. United Nations University Press, U.S.A.

Kelly, R. M. 1998. "An inclusive democratic polity, representative bureaucracies, and the New Public Management” in Public Administration Review, May/June 98, Vol. 58 Issue 3.

Kiggundu, M. 1991. Size and cost of the Civil service reforms: Reform programmes in Africa. United nations Department of Technical Cooperation and Development (UNDTCD).

Lagos State Public service Manpower Statistics (2002), published by the Ministry of Establishment and Training (MSD), Secretariat, Ikeja.

Land, T. 2002. Placing Technical cooperation at the Service of Capacity Development: Emerging Lessons. ECMPM Bulletin. Maastricht.

Larbi, G.A .1998 "Management decentralization in practice: A comparison of Public Health and water services in Ghana" in Minogue, M., Polidano, C., and Hulme, D.(eds) Beyond the New Public Management: Changing Ideas and Practices in Governance. Blackwell Publishing.

LeCompte, M.D, and Preissle, J. (1993). Ethnography and qualitative design in educational research (2nd ed.). San Diego: Academic Press.

Lepak, D.P., and Snell, S.A. 2002. "Examining the Human Resource Architecture: The Relationships Among Human Capital, Employment, And Human Resource Configurations" Journal of Management 2002 28(4) 517-543

Lienert, I. 1998, “A decade of Civil service reforms in sub-Saharan Africa", working paper, Washington DC: International Monetary Fund.

Lipset, S.M, and Lenz, G.S. 2000, "Corruption, Culture, and Markets", in Culture Matters, Lawrence E. Harrison, and Samuel P. Huntington, eds., (New York: Basic Books)

Manning, N. 2001. "The legacy of the New Public Management in the developing countries". International Review of Administrative Sciences [0020-8523(200106) 67:2] SAGE Publications. 
Marshall, C. and Rossman, G. 1995. Designing qualitative research (2nd ed.). Thousand Oaks, C.A: Sage

McCourt, W. 1999 "Human resources management in the UK Public service: Its practice and its relevance to public reformers in South Africa. Human Resources in Development group working paper series. Working paper no 8 .

\section{MDGD/UNDP 1998 Civil service Reform Paper}

Mesquita, de B.B and Root ed., H.L 2000. “Governing For Prosperity”. Yale University Press/ New Haven and London.

Mesquita, de B.B. and Root, H.L, 2000. "When Bad Economics is Good Politics" in Governing for Prosperity. Ed. By Mesquita, B. B. and Root, H.L

Mihyo, P.B. 2002. "Environmental Governance, Policies, and Politics in Eastern and Southern Africa" pp.125140 in Better Governance and Public Policy, Olowu, D. and Sako, S. ed. Kumarian Press, Bloomfield, U.S.A.

Moharir, V. 2002. "Governance and Policy Analysis" pp. 107-124 in Better Governance and Public Policy, Olowu, D. and Sako, S. ed. Kumarian Press, Bloomfield, U.S.A.

Mutahaba, G. and Balogun, J., eds. 1992. Enhancing Policy Management Capacity in Africa. West Hartford, Conn.: Kumarian Press

Mutahaba, G. et al. 1993. "Vitalizing African Public Administration for Recovery and Development" West Hartford C.T: Kumarian Press

Mutahaba, G. 1989. Reforming Public Administration for Development-Experiences from Eastern Africa. Kumarian Press, Inc.

Mutahaba, G. and Kiragu, K. 2002. "Lesson of Public service Reform from Five African Countries" in Africa Development Vol. Xxvii, nos. 3\&4, ed. Dele Olowu.

Newberry, D. 1988. "Agricultural Taxation: The Main Issues," in David Newberry and Nicholas Stern, eds., The Theory of Taxation for Developing Countries, Oxford: Oxford University Press.

North, D. 1990. Institutions, Institutional Change, and Economic Performance. Cambridge: Cambridge University Press

Odubogun, P. Kassey. 1992. Management Theory: Relevance for Management Practice in Nigeria. Maastricht, T.O offset.

Ogiogio, G. and Ongile, G. 2002. "The ACBF-PACT Model as a Best Practice Model for Capacity Building” pp. 85-106 in Better Governance and Public Policy, Olowu, D. and Sako, S. ed. Kumarian Press, Bloomfield, U.S.A.

Olisadebe, E.U., “Trends in Nigeria's Balance of Payments (1980-1994)” in Central Bank of Nigeria Economic and Financial Review, vol.33, June 1995.

Olowu, D. and Sako, S. eds., 2002. "Better Governance and Public Policy: Capacity Building for Democratic Renewal". Renewal, Bloomfield, Kumarian Press.

Olowu, D., "Reforming African Civil service reforms", pages 1-23, The Journal of Modern African Studies, 37 , 1 (1999).

Olowu, D., 1990. Lagos State - governance, society and economy, Malthouse Press Limited

Olowu, D., 1992 “A critique of the reforms" pp 135-152, in Civil service transformation for structural adjustment Victor Ayeni (ed), Nigerian Institute of Management 
Olowu, D., 2001 "Pride and performance in African Public services: analysis of institutional breakdown and rebuilding efforts in Nigeria and Uganda", International Review of Administrative Sciences, pp. 117-134.

Olowu, D., Otobo, E., Okotoni, M. "The role of the Civil service in enhancing development and democracy: an evaluation of the Nigerian experience". Paper presented at Civil service system in comparative perspective, School of Public and Environmental affairs, Indiana University, Bloomington, Indiana, April 5-8, 1997.

Olowu, D. and Adamolekun, O. “Human Resources Management” pages 87-106 L. Adamolekun (ed) Public Administration in Africa: Main Issues and Selected Country Studies, Westview Press, Washington, 1999

Olowu, D. 2002 "New Public management: An African Reform Paradigm?” in African development, Vol. XXVII, Nos. 3 \& 4 pp. 1-16. Council for the Development of Social Science Research in Africa.

Osoba, S. (1996) 'Corruption in Nigeria: Historical Perspectives' Review of African Political Economy No. 69, pp. 371-386

Ostrom, E. 1991. Governing the Commons. Cambridge: Cambridge University Press.

Ostrom, V. 1997. The meaning of Democracy and the Vulnerability of Democracies. Ann Arbor, Michigan.: University of Michigan Press.

Osokoya, I.O. 1995. Alhaji Lateef Jakande: The Educational Reformer. Laurel Educational Publishers Ltd. Ibadan, Nigeria.

Otobo, E. 1999. Nigeria, in Public Administration in Africa: Main Issues and Selected Country Studies. Ed. by Ladipo Adamolekun. Westview Press, Oxford.

Oyelaran-Oyeyinka, O et al. 1997. Ailing Public enterprise: Technological Project Failures and Prospects for Industrial Renewal in Nigeria. Raw Material Research Council, Abuja, Nigeria.

Patton, M.Q. (1990). Qualitative evaluation and research methods (2nd ed.). Newbury Park, CA: Sage

Peters, G., 1996, The Future of Governing, Lawrence, KS: University of Kansas Press.

Phillips, D. 1992. "Elements and Justification" in Civil service transformation for structural adjustment ed. By Victor Ayeni. Nigerian Institute of Management.

Polidano, C. 2001. "Why Civil service reforms fail". IDPM Public Policy and Management Working Paper no.16.

Polidano, C. 1999 The New Public Management in Developing Countries. Institute for Development Policy and Management, University of Manchester.

Pollitt, C. 1996. The New Public Management In Western Countries and its Evaluation" Evaluation News and Comment Magazine, Vol. 5, No. 1, June 1996.

Public service Review Commission, 1974. Nigeria: Federal Government Printer

Rhodes, R.A.W. 1996. The new governance: governing without Government. Political Studies No. XLIV: 65267

Riker, W.H. 1964. Federalism. Boston.

Robbins, S.P. 2003. Organizational Behavior. 10th Ed. New Jersey: Prentice- Hall, Inc.

Rondinelli, D.A. 1981. "Government Decentralization in Comparative Perspective: Theory and Practice in Developing Countries" The International Review of Administrative Sciences. Public administration Technical Cooperation- Economic Assistance Publication. 
Sako, S. 2002. "The Public- Private Sector Interface- The ACBF Perspective"' in Better Governance and Public Policy, Olowu, D. and Sako, S. ed. Kumarian Press, Bloomfield, U.S.A.

Salih, M.A.M., 2002. "Environmental Governance, Policies, and Politics in Eastern and Southern Africa"' in Better Governance and Public Policy, Olowu, D. and Sako, S. ed. Kumarian Press, Bloomfield, U.S.A.

Salisu, M. 2001. "The incentive structure, Civil service efficiency and the hidden economy in Nigeria" Discussion Paper No. 2001/86 United Nations University/WIDER

Salisu, M. 2003. "The incentive structure, Civil service efficiency and the hidden economy in Nigeria" in Reforming Africa's Institutions: Ownership, Incentives, and Capacities. Kayizzi-Mugerwa, S. ed. United Nations University Press, U.S.A.

Sandbrook, R. 1985. The Politics of Africa's Economic Stagnation. Cambridge: Cambridge University Press.

Saunders, M., Lewis, P., Thornhill, A., 2000. Research Methods for Business Students, 2nd Edition. Great Britain: Pitman Publishing.

Schacter, M. 2000. Public Sector Reform in Developing Countries: Issues, Lessons and Future Directions Institute on Governance, Ottawa, Canada

Sen, A. K. 1999. Development as Freedom. Knopf, New York.

Simon, H. 1957. Administrative Behavior: A Study of Decision-Making Processes in Administrative Organization. Free Press, New York.

Schick, A. 1998. "Why Most Developing Countries Should Not Try New Zealand's Reforms" World Bank Research Observer 13 (1): 123-131

Schultz, T.W. 1961. "Investment in Human Capital” American Economic Review, 52: 1-17

Shodipe, U. A. 1997. From Johnson to Marwa: 30 years of Governance in Lagos State. Malthouse Press Ltd. Lagos, Nigeria.

Smith, B. 1982. "The Revenue Position of Local Government in Nigeria” Public Administration and Development, vol.2: 1-14.

Stepan, Alfred, 1999, "Federalism and Democracy: Beyond the U.S. Model." Journal of Democracy 10: 19-34.

Tannenbaum, R., Schmidt, W.H (1958). "How to choose a leadership pattern" Harvard Business Review 36/2, 1958: 95-101.

Terry, L.D. 1998. "The Administrative Leadership, Neo-Managerialism, and the Public Management Movement" Public Administration Review, 58 (3): 194-200

Therkildsen, O. 2001 “Efficiency, accountability and implementation: Public sector reforms in East and Southern Africa. Democracy, Governance and Human Rights -UNRISD.

Tsikata, Y. M. 2003. "A comparative study of Ghana and Tanzania” in Reforming Africa's Institutions: Ownership, Incentives, and Capacities. Kayizzi-Mugerwa, S. ed. United Nations University Press, U.S.A.

United Nations Development Programme, 1997. Reconceptualizing Governance. Discussion Paper No. 2. New York, Management Development and Governance Division.

United Nations Research Institute for Social Development Bulletin. Summer 2001 .No 24.

Walt, G. 1994 Health policy: an introduction to process and power. Johannesburg: witwater-sand University Press.

Weber, M. 1947. The Theory of Social and Economic Organization) translated by A. M. Henderson and T. Parson. Oxford University Press, New York. 
Wescott, C. 1999 "Guiding principles on Civil service reforms in Africa: An empirical review" International Journal of Public Sector Management 12 (2-3)

Wilson, W.1941. "The study of public administration”, Political Science Quarterly, vol. 2, June 1887; reprinted in the Quarterly, vol. 56, December 1941.

Wong, L. 1995. Thailand: New Asian Tiger? http://csf.colorado.edu/ipe/po497/lee/thesis.html

World Bank. 1981. Accelerated Development in Sub-Saharan Africa: An Agenda for Action, Washington, D.C. World Bank

World Bank. 1997, World Development Report 1997: The changing role of the State. New York: Oxford University Press.

World Bank, 2000. African Economic Indicators, World Bank, Washington

World Bank. Nigeria: State and Local Government in Nigeria. The World Bank, AFTPR, Africa Region, 2002.

Wunsch, J. and Olowu, D. 1990.The Failure of the centralized State: institutions and self-governance in Africa. San Fransisco: Institute for Contemporary Studies.

Yin, R.K. 1994, "Case Study Research: Design and Methods" Second Edition. Applied Social Research Methods Series Volume 5. Sage Publication

Zaltman, G., Pinson, C.R.A., and Angelmar, R. 1977. "Metatheory and Consumer Research.” New York: Holt, Rinehart and Winston. 


\title{
Appendix I
}

\section{$\mathrm{M}_{1,102} \overline{\bar{Q}} \mathrm{M}_{2002}$ \\ 50 YEARS}

\section{Contents of the interview for the governors}

\author{
GENERAL INFORMATION
}

1. If I am to write your biography what will you say about yourself?

\section{LEADERSHIP PERSPECTIVE}

2. When you took on the mantle of leadership did you anticipate the magnitude of problems you met?

3. To solve these problems, what key plans, programmes and policies did you initiate?

4. During your tenure did you establish any formal system of evaluating policies/programmes initiated by your government?

5. Finally as a leader how would you assess yourself, in terms of visions, initiating changes, achievements, and your relationship with the staff and public

\section{CITIZENRY PERSPECTIVE}

6. At the inception of your governance you made some promises to the citizens were you able to fulfill them?

7. Did you ever have an objective feedback about the performance of your government from the citizenry?

8. Was there any element of trust between you and the people governed?

9. In retrospective is there anything you would have done otherwise in terms of your policies and programmes?

\section{VIEWS ON THE CIVIL SERVICE AS AN INSTITUTION}

10. Do you think the civil service has the institutional capacity like human, physical and financial to effectively implement government's policies?

11. Did your government encourage political neutrality of civil servants?

12. What would you attribute the poor performance or unprofessional conducts of civil servants to?

13. What are your thoughts on lack of transparency and accountability in the public sector? 


\section{Appendix II}

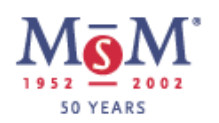

\section{Contents of the interview for the informants}

1. Can you please tell me about your background?

2. Why did you prefer to work for the Lagos State Government rather than other public (e.g. federal or state) or private sector organization?

3. How long have you worked in the service?

4. Which Ministries have you worked in?

5. Please compare the civil service you joined with its present situation.

6. Can you please indicate some government policies that you think affected the civil service positively or negatively, especially in terms of their effects on its institutional capacity (human, physical and financial)?

7. Some observers note a decline in the civil service; as a policy maker, would you say that there is such a decline? In what sense? Is it in respect of human, institutional, organizational, or infrastructural or others?

8. If there is a decline in the service, at what point would you say that it became evident? What were the relevant conditions under which this happened?

9. To what extent was the quality of the civil service dependent on the leadership quality and ability of the Governor(s) that you served under? Please specify.

10. To what extent could the Governor(s) be assessed as a visionary leader?

11. Please indicate in which way the respective Governor's policies affected the service positively?

12. What about the ones that affected the service negatively?

13. Which factors, all in all, do you think were mainly responsible for positive or negative developments in the Lagos Civil Service?

14. Which other issues and actors do you think need to be taken into account to properly understand the evolution of the Lagos Civil Service?

15. To what extent do you think that education and training are significant in the evolution of the Lagos Civil Service? Please rank in importance to the other factors mentioned.

16. Have you had personal experience with education and training programmes of the Civil service? If so, how do you evaluate the contribution of these programmes?

17. Have members of your staff received education or training in such programmes? What were their experiences? What were the results of their training in their day-to-day functioning?

18. Do you think the people trust the government more today than five or ten years ago? Why and why not?

19. Whom do you suggest that I contact for another view on the relevant issues?

20. May I use your name in my final report or do you wish these comments to be considered 'off the record'? 


\section{Appendix III}

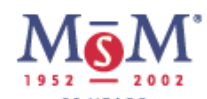

50 YEARS

\section{The Evolution of Nigeria's Public service: \\ Case study of the Lagos State Civil service}

\section{VIEWS ON THE CIVIL SERVICE AS AN INSTITUTION}

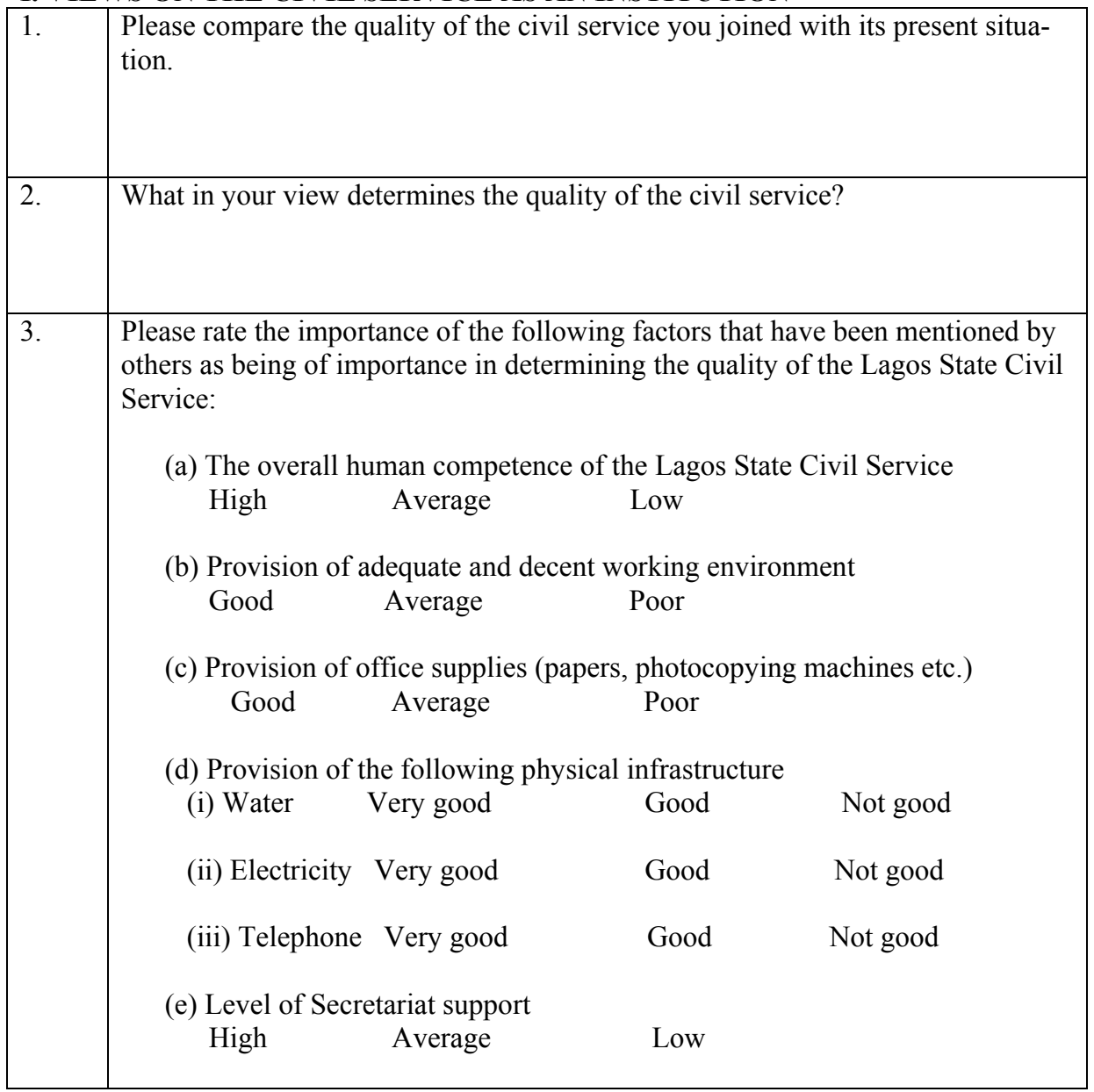




\begin{tabular}{|l|l|}
\hline & \multicolumn{1}{|c|}{$\begin{array}{c}\text { (f) Level of Internet and computer support } \\
\text { High } \quad \text { Average }\end{array}$} \\
\hline 4. & $\begin{array}{l}\text { Do you think the Lagos State Civil Service has the institutional capacity like } \\
\text { competent staff, managerial supports, office supplies etc to make appropriate } \\
\text { policy formulations and to effectively implement them? Please explain. }\end{array}$ \\
\hline 5. & $\begin{array}{l}\text { It is believed that the size of government is excessive? If it is true, what caused } \\
\text { it? }\end{array}$ \\
\hline 6. & $\begin{array}{l}\text { Do you think Lagos State has adequate financial resources to provide a reason- } \\
\text { able level of public service to the populace? }\end{array}$ \\
\hline 7. & $\begin{array}{l}\text { Do past and present governments have a formal system of evaluating its pro- } \\
\text { grammes and projects? Please explain. }\end{array}$ \\
\hline 8. & $\begin{array}{l}\text { Do past and present administrations have an established bureau for public com- } \\
\text { plaints? Please specify. }\end{array}$ \\
\hline 9. & $\begin{array}{l}\text { Do you think that the military administrations trust the civil servants to imple- } \\
\text { ment their programmes effectively? Why and why not? }\end{array}$ \\
\hline 10. & $\begin{array}{l}\text { Do you think that the civilian administrations trust the civil servants to imple- } \\
\text { ment their programmes effectively? Why and why not? }\end{array}$ \\
\hline Winistrations? Please explain.
\end{tabular}


II. VIEWS ON DETERMINANTS OF DECLINE

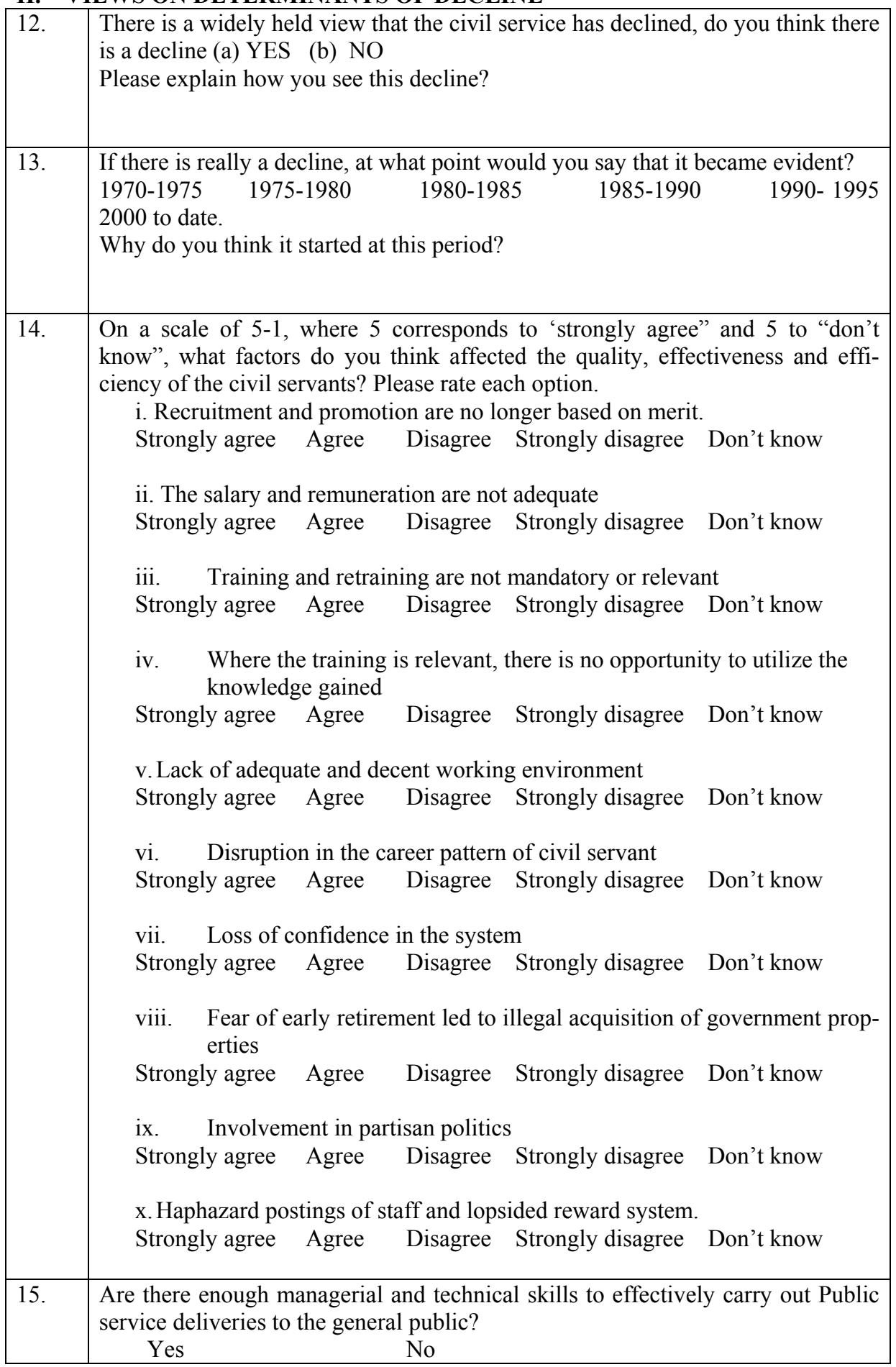




\begin{tabular}{|c|c|}
\hline 16. & $\begin{array}{l}\text { If yes, is the public satisfied with the level of public service deliveries given to } \\
\text { them? Please specify. }\end{array}$ \\
\hline 17. & $\begin{array}{l}\text { Are there transparency and accountability in the civil service? } \\
\text { Yes } \\
\text { No }\end{array}$ \\
\hline 18. & If no, in which areas are these lacking? \\
\hline 19. & $\begin{array}{l}\text { Are Ministries evaluated annually or output measured against expenditure in- } \\
\text { curred? } \\
\text { Yes }\end{array}$ \\
\hline 20. & If yes, do these affect government's projections and activities? Please specify \\
\hline 21. & $\begin{array}{l}\text { On a scale of 5-1, where } 5 \text { corresponds to 'strongly agree" and } 5 \text { to "don't } \\
\text { know", please rate whether the Federal Government macroeconomic policy of } \\
\text { Structural Adjustment Programme adversely affected the government perform- } \\
\text { ance. } \\
\text { i. Downsizing of the Government through early retirement and laying off of } \\
\text { staff } \\
\text { Strongly agree Agree Disagree Strongly disagree Don't know } \\
\text { ii. Wage erosion (staff are earning less) } \\
\text { Strongly agree Agree Disagree Strongly disagree Don't know } \\
\text { iii. Wage compression (the difference between the wages of the senior } \\
\text { and the junior staff gets smaller) } \\
\text { iv. Inflation through the devaluation of the Naira } \\
\text { Strongly agree Agree Disagree Strongly disagree Don't know }\end{array}$ \\
\hline 22. & $\begin{array}{l}\text { Lagos State is regarded as the commercial nerve of Nigeria, and this has brought } \\
\text { a lot of people into the state. Do you think that the state has the capacity and ca- } \\
\text { pability to cater for this influx of people in terms of social amenities? } \\
\begin{array}{lll}\text { (a) YES } & \text { (b) NO } & \text { Please explain. }\end{array}\end{array}$ \\
\hline 23. & $\begin{array}{l}\text { Do you think that the state has appropriate and adequate revenue collection ma- } \\
\text { chinery? (a) YES } \\
\text { (b) NO } \\
\text { Please explain. }\end{array}$ \\
\hline 24. & $\begin{array}{l}\text { On a scale of 5-1, where } 5 \text { corresponds to 'strongly agree" and } 5 \text { to "don't } \\
\text { know", what factors do you think can contribute to the success of government? } \\
\text { i. Effective leadership } \\
\text { Strongly agree Agree Disagree Strongly disagree Don't know } \\
\text { ii.Competent staff }\end{array}$ \\
\hline
\end{tabular}




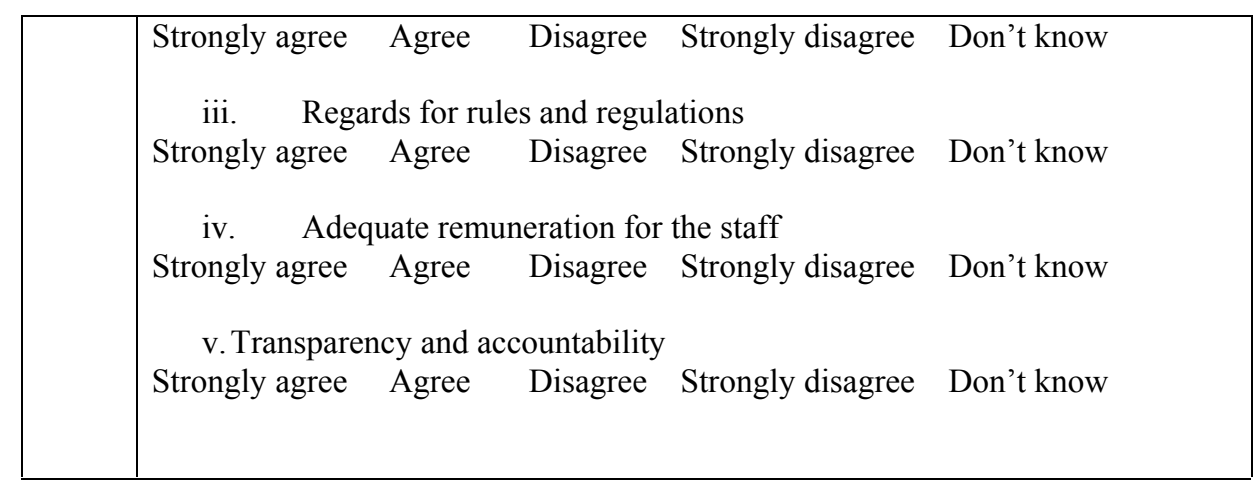




\section{VIEWS ON VARIOUS REFORMS}

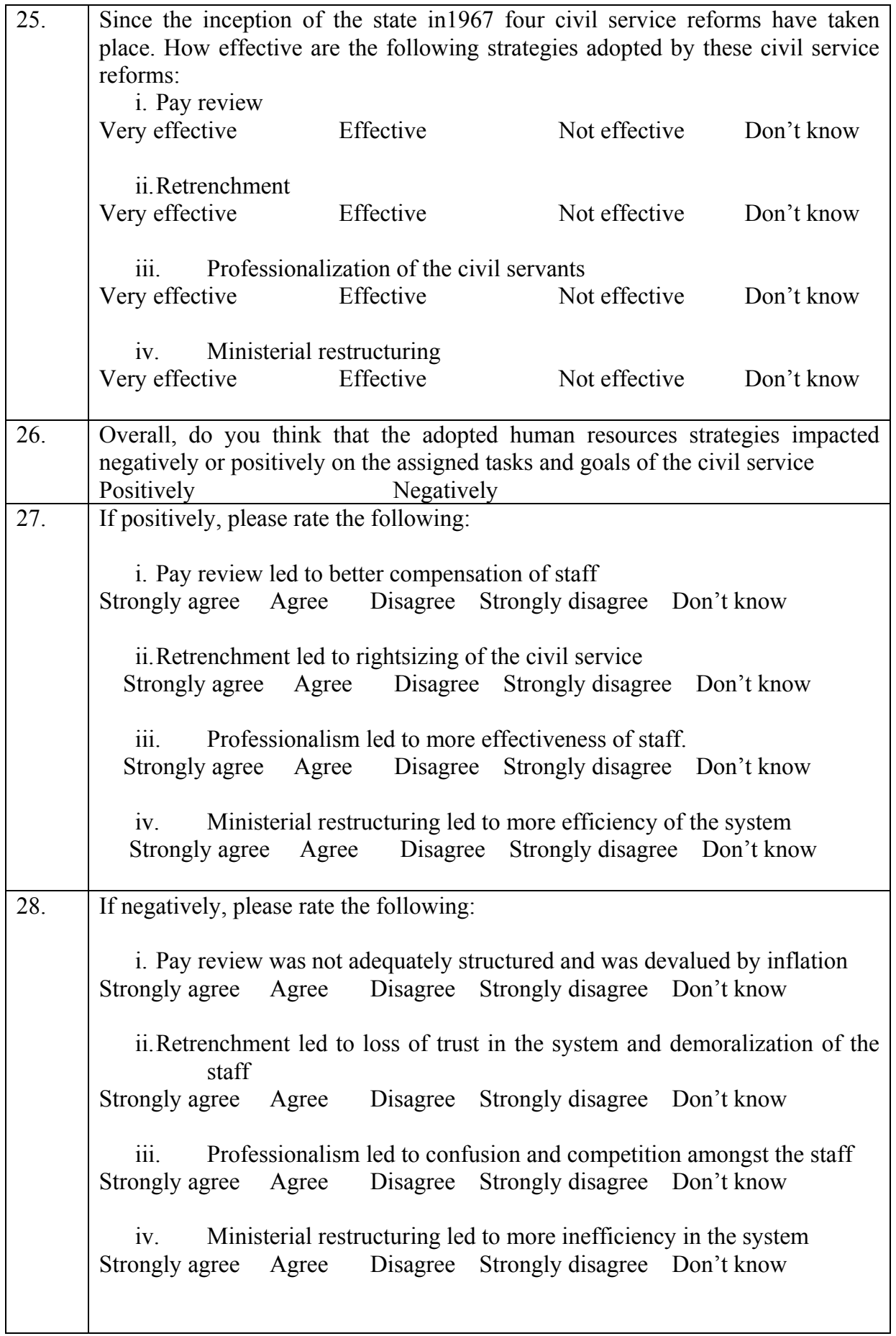




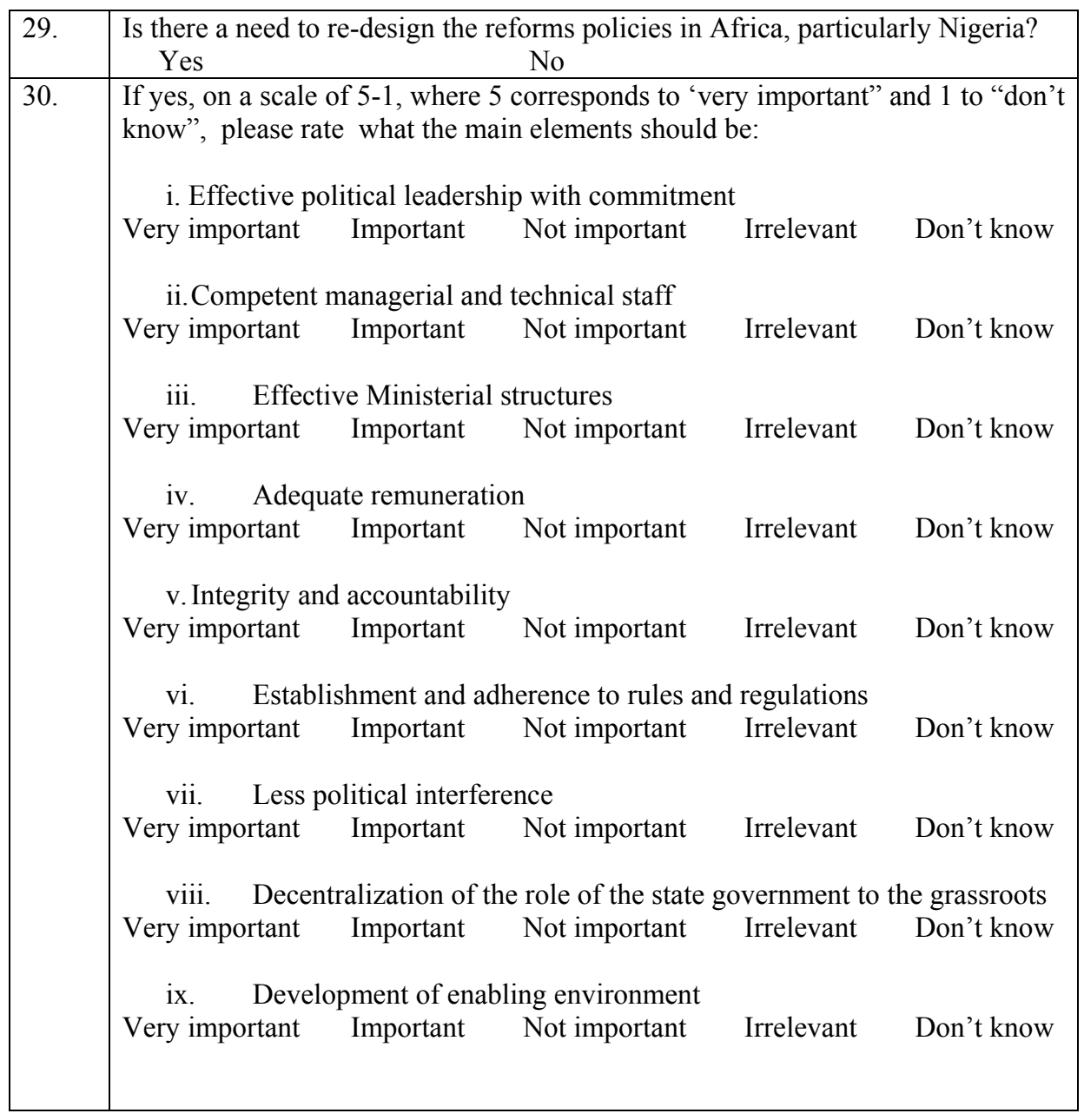




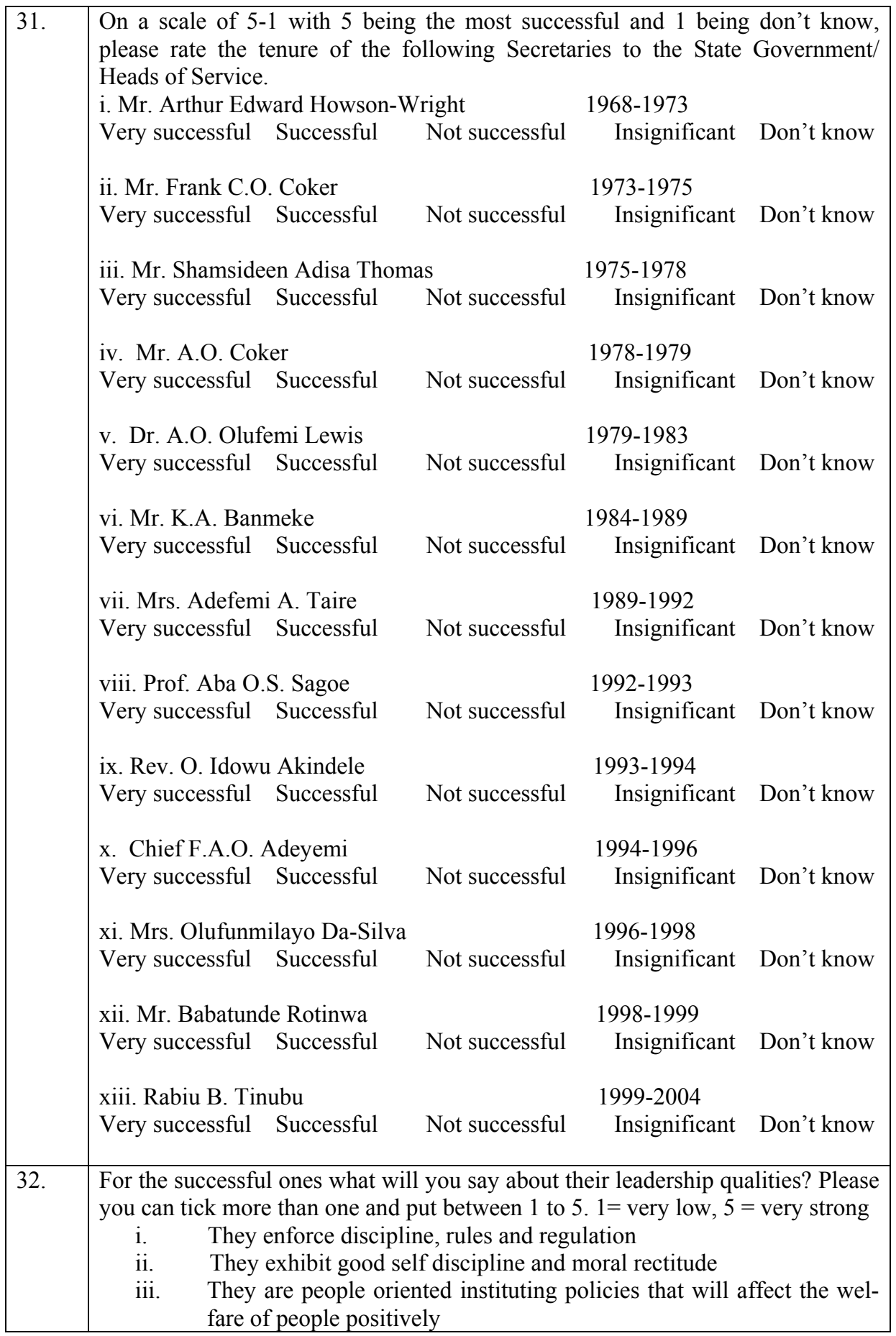




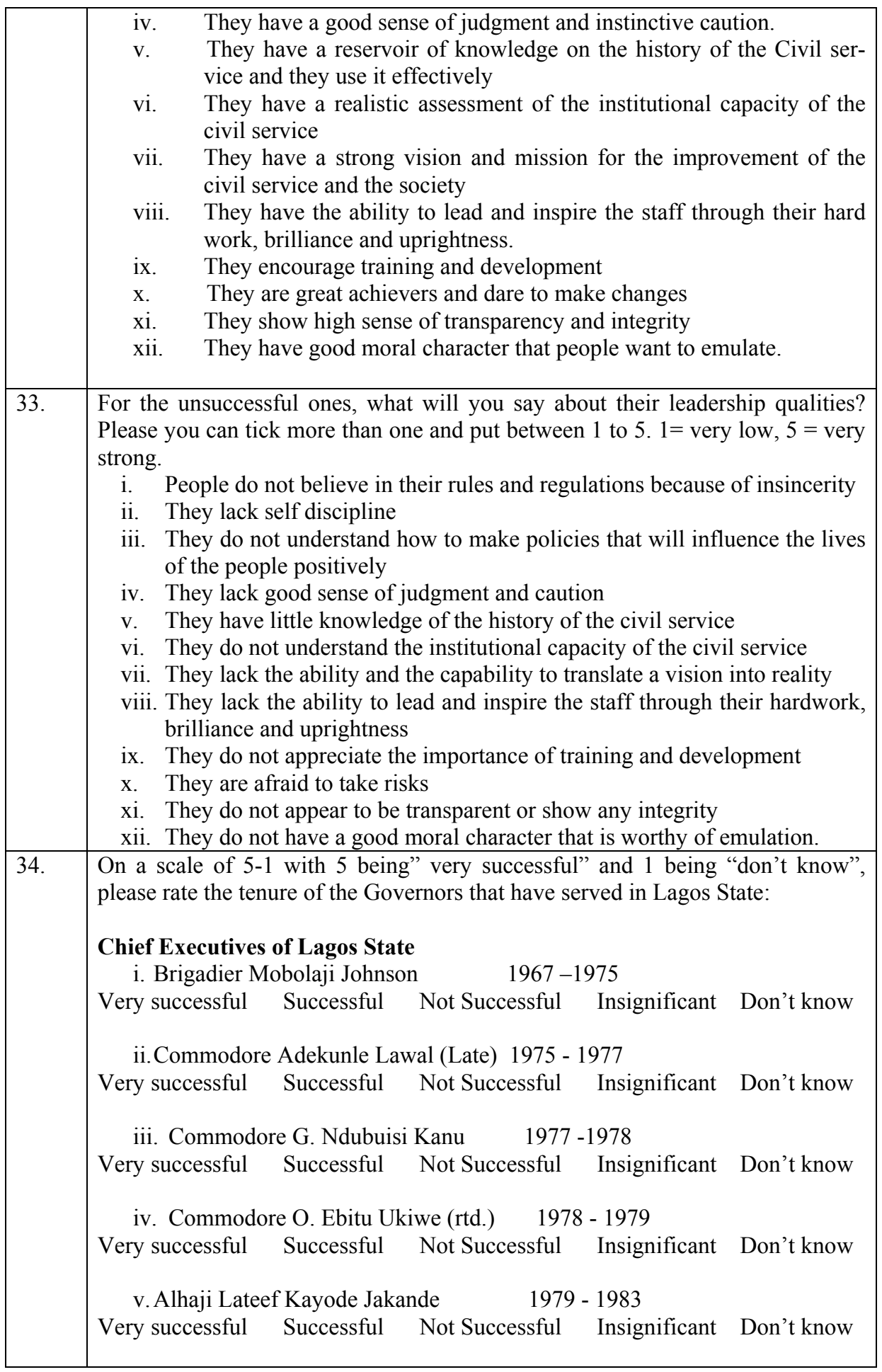




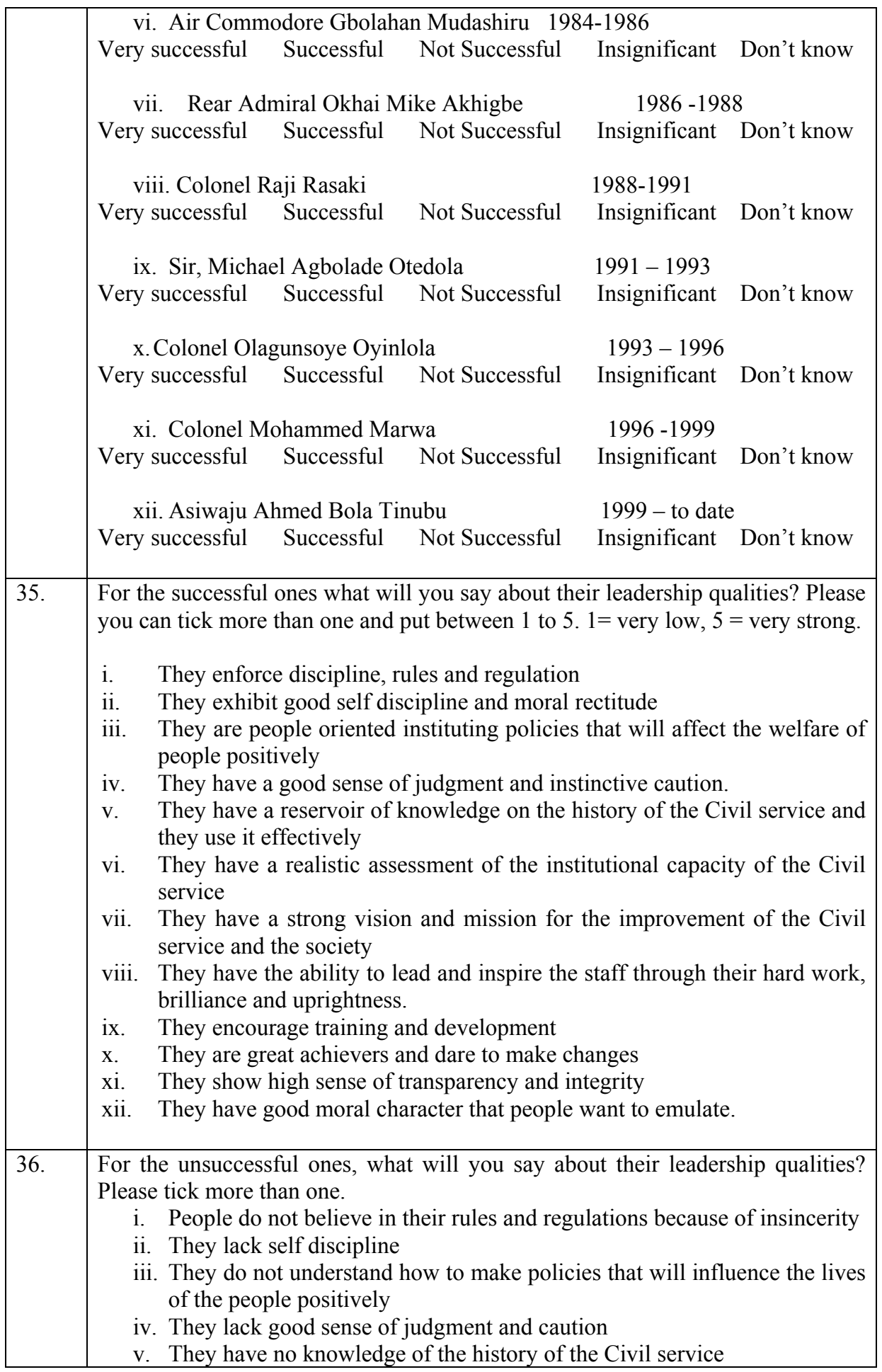




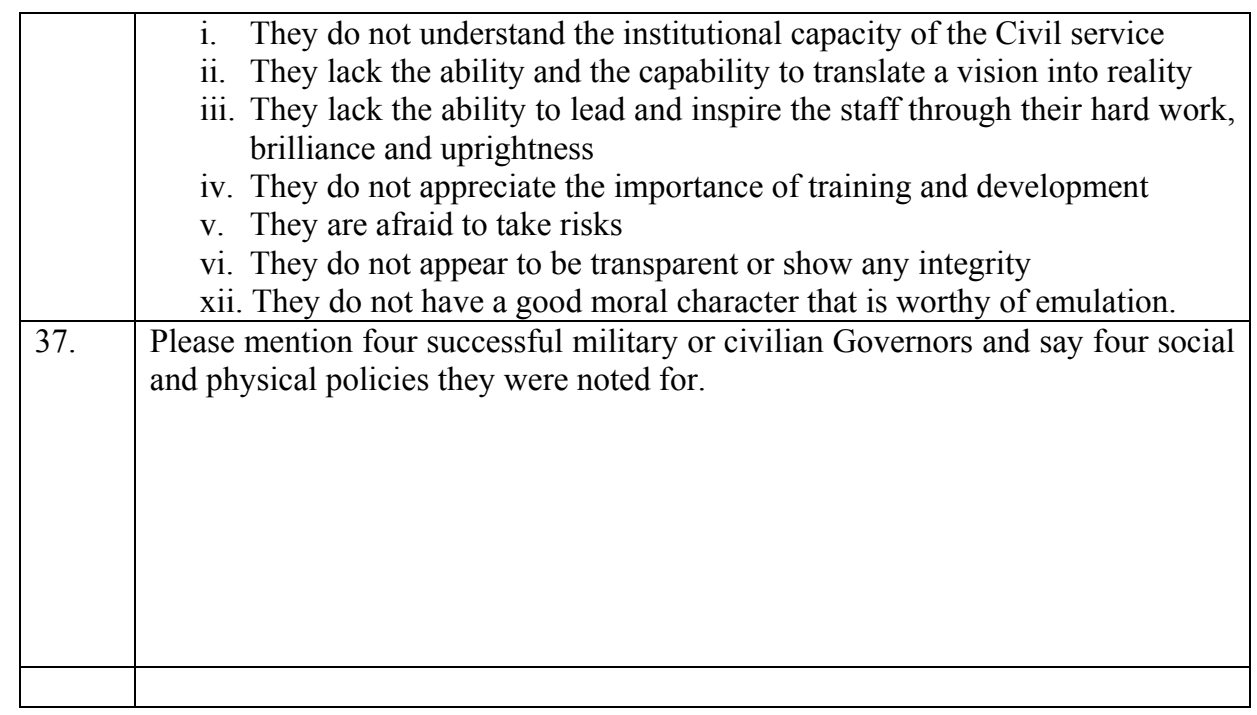

38. What do you think are the pressing social and physical infrastructural needs of Lagos State? Please tick five items and rate between 1 to $5.1=$ very low, $5=$ very strong.

\begin{tabular}{|l|l|l|l|l|l|}
\hline Category & 1 & 2 & 3 & 4 & 5 \\
\hline Education & & & & & \\
\hline Health & & & & & \\
\hline Food & & & & & \\
\hline Housing & & & & & \\
\hline Security & & & & & \\
\hline Roads & & & & & \\
\hline Transport & & & & & \\
\hline Water & & & & & \\
\hline Waste Disposal & & & & & \\
\hline Drainage & & & & & \\
\hline Employment & & & & & \\
\hline
\end{tabular}




\section{Personal Information}

\begin{tabular}{|c|c|c|}
\hline No & Questions & Response Options \\
\hline 39. & Sex & Female \\
\hline 40. & Age & $\begin{array}{lll}\text { 1. } 18-30 & 2.31-40 & 3.41-50 \\
\text { 4. } 51-60 & & \end{array}$ \\
\hline 41. & Qualification & $\begin{array}{lll}\text { 1. Primary } & \text { 2. Secondary } & 3 . \text { Polytechnic } \\
\text { 4. University } & \text { 5. Others }\end{array}$ \\
\hline 42. & $\begin{array}{l}\text { Year of graduation for the } \\
\text { highest level of education }\end{array}$ & \\
\hline 43. & What is your grade level? & \\
\hline 44. & Date of first appointment & \\
\hline 45. & Designation & \\
\hline 46. & Ministry & \\
\hline 47. & $\begin{array}{l}\text { Which Ministries have you } \\
\text { worked in? }\end{array}$ & \\
\hline 48. & $\begin{array}{l}\text { How many personnel do you } \\
\text { have under your supervision? }\end{array}$ & \\
\hline 49. & $\begin{array}{l}\text { Why did you prefer to work } \\
\text { for the Lagos State Govern- } \\
\text { ment rather than other public } \\
\text { (e.g. Federal or city) or Private } \\
\text { Sector Organization? }\end{array}$ & \\
\hline 50. & $\begin{array}{l}\text { How long have you worked in } \\
\text { the service, including those at } \\
\text { the federal or local govern- } \\
\text { ments? }\end{array}$ & \\
\hline
\end{tabular}

Thank you for your co-operation. The efforts you put into the filling of the questionnaire is very much appreciated.

Signed

R.N.I. Oyeyinka (Mrs.) 


\title{
Samenvatting (Summary in Dutch)
}

\author{
MACHT EN BUREAUCRATIE: \\ LEIDERSCHAP IN NIGERIAANS OPENBAAR BESTUUR
}

Het overheidsapparaat in Lagos State, Nigeria (1967 - 2005)

Er bestaat overeenstemming onder beleidsadviseurs en onderzoekers dat het openbaar bestuur in de meeste ontwikkelingslanden een noodzakelijke voorwaarde is voor economische- en sociaal-politieke ontwikkeling van deze landen (Olowu 1999; World Bank 1997) met name door de relatieve zwakte van de particuliere sector. Het openbaar bestuur (civil service) en de daarmee samenhangende dienstverlening (public service) vormt een essentiële maatschappelijke institutie voor de vorming en uitvoering van overheidsbeleid. Niettemin bestaat er steeds meer bewijs voor een afnemend functioneren van openbare dienstverlening in Afrika. De geobserveerde tekortkomingen worden in verband gebracht met ontoereikend macroeconomisch beleid, ontoereikende institutionele capaciteit, bekwaamheid van de overheid, politiek wanbestuur en de afwezigheid van democratie (Mutahaba 1989; Therkilsen 2001). Internationale organisaties en financiële instellingen stellen dat het hoge niveau van armoede en corruptie in Afrika in verband gebracht kan worden met politiek wanbestuur.

Nigeria is het dichtstbevolkte land van Afrika met een bevolking van meer dan 120 miljoen zielen. Het land verwierf onafhankelijkheid van Engeland in 1960. In de jaren na de onafhankelijkheid werd de Nigeriaanse openbare dienstverlening beschouwd als één van de beste in het Afrikaanse continent (Murray; 1972). Deze belangrijke institutie is echter aangetast door zowel militaire- als burger regeringen. Aanzienlijke vooruitgang is geboekt in de beginjaren maar deze kon niet behouden worden, door factoren die in deze studie aan bod komen.

Er zijn verschillende pogingen gedaan om de openbare dienstverlening in Afrika te verbeteren. De verbetering van prestaties binnen het ambtenaren apparaat vormde een wezenlijk onderdeel van het Structureel Aanpassingsprogramma (SAP) in de jaren '80. Dit programma werd opgezet en uitgevoerd door de Wereld Bank en andere organisaties. Het hervormen van de openbare dienstverlening is een ingewikkeld proces dat diepgaande veranderingen in beleid, strategieën en regeringsprogramma's ten gevolge kan hebben om beter te kunnen anticiperen op maatschappelijke behoeften. Het is echter duidelijk dat de hervormingen in verschillende Afrikaanse landen gefaald hebben. In Nigeria ontbreekt systematisch onderzoek naar de rol van bestuur en bureaucratie in de openbare dienstverlening en het effect op het politiekeen sociaal-economische milieu in het land.

Ook de invloed van politiek leiderschap op de bureaucratische structuur van overheidsorganisaties, in het bijzonder op de openbare dienstverlening, wordt van toenemend belang gevonden. Deze studie stelt dat de rol van politieke leiders, (zowel militairen als burgers), van wezenlijk belang is voor het functioneren van de overheid en voor de openbare dienstverlening. Met andere woorden, de effectiviteit van de regering wordt diepgaand beïnvloed door leiderschapkwaliteiten.

De invloed van de leiders, voornamelijk Executive Governors ("militair/autoritair" of "burger/democratisch"), op het formuleren en implementeren van publiek beleid beïnvloedt het functioneren van de openbare dienstverlening. De kwaliteit van de bureaucratie en de wijze waarop politieke- en bureaucratische instituties met elkaar zijn verbonden, bepalen samen het functioneren van openbaar bestuur en dienstverlening. 
Sinds de onafhankelijkheid heeft Nigeria twee type regeringen gekend, militair en burger. De politieke geschiedenis van ontwikkelingslanden zoals Nigeria en Aziatische landen als Maleisië en Indonesië, is niet zonder moeilijkheden geweest. Deze landen hebben zeer verschillende politieke- en economische structuren. Ondanks de relatieve politieke instabiliteit die deze landen hebben meegemaakt, zijn sommige erin geslaagd een economische groei te bewerkstelligen. Economische groei vormt een goede indicator voor het functioneren van de overheid in deze landen.

Politieke leiders met een ontwikkelingsgeorienteerd beleid dragen bij aan de groei van de institutionele capaciteit van de overheid en zijn in staat een goed beleid te ontwikkelen die welzijnsniveau van de bevolking verbetert en voorziet in de basisbehoeftes aan onderwijs, gezondheidszorg, voeding en behuizing (Adamolekun, 2002:10). De kwaliteiten van politieke leiders beïnvloeden de beleidsformulering en uitvoering en dit beïnvloedt op zijn beurt het functioneren van het ambtenarenapparaat. Sommige politieke leiders functioneren relatief beter dan anderen onder de verschillende politieke regimes. Deze studie probeert te achterhalen wat hiervan de oorzaak is.

Het onderzoek richt zich op de evolutie van de openbare dienstverlening in de staat Lagos (1967 - 2005). Het hanteert een combinatie van kwalitatieve- en kwantitatieve onderzoekstechnieken zoals enquêtes en case studies. Een kwantitatieve analyse poogt statistisch significante relatie te bepalen tussen de afhankelijke variabele (functioneren van de openbare dienstverlening) en verklarende factoren (als leiderschapskwaliteiten). De verkregen resultaat dragen bij aan een beter begrip van de rol van overheidscapaciteit in het algemeen en de invloed van politiek leiderschap op Nigeriaanse openbare dienstverlening. 


\section{About the Author}

Rosamund Naduvi Ibiyemi Oyelaran-Oyeyinka (nee Lawson) was born in Lagos Island, Lagos State, Nigeria on February 15, 1957. She obtained her first University degree in Sociology from the University of Ife, Ile-Ife (now Obafemi Awolowo University), Nigeria in 1979. She was awarded a Masters Degree in the same discipline from York University, Toronto, Canada in 1983. From 1979 till 2001 she worked in the three tiers of the Nigerian Government: Federal, State and Local. She is an administrator and researcher by profession. Her professional interest remains administration and capacity development and strengthening.

She has been a staff of Lagos State Government from 1987. She attained the position of Assistant Director in 1999 and served in this capacity for three years before proceeding on study leave. In 2002 she started a doctoral programme with the Maastricht School of Management (MSM), Maastricht that led to the award of Masters of Philosophy. She completed the requirement for a PhD programme in Maastricht University, Faculty of Arts and Culture, Department of social science and Technology in 2006. 